\title{
قـضـا \&
}

\section{دسترب محكمي نشراتي اركان}

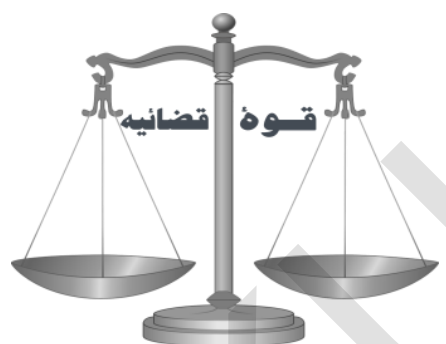

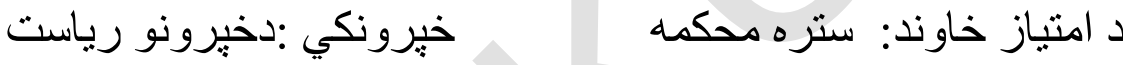
د لبكنى هلئ.
يو هندوى عبدالقادر عدالتخو اه
دوكتور عبدالملك"كاموي" دوكتور عبداله عطائى قضاو تيوه بر ات على منتين
قضاوت يوه محمد عثمان زوبل

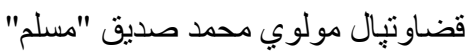
قضاوت بوه حضرت كل حسامى
قضاوتيوه غوث الدين مستمند غورى

Publlcatlon@supremecourt.gov.af www.supremecourt.gov. af

$$
\text { مسئول مدير : محمد صديق زوبل }
$$

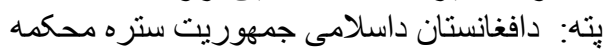
تيلفون: 23003612302263 ديز اين او كميوز: وحيدالَه "اسديار" 


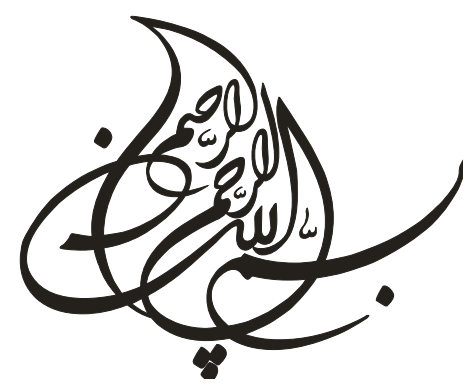

فهرست مطالب:

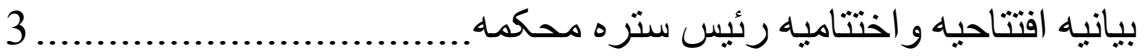
ضميمه شماره (4) قانون جز اء........................................................... از متحدالمالهاى ستره محكمه................................................................... بررسى نقش زن در خانو اده و اجتماع.........يو هنو ال عبدالقادر عدالتخو اه 43

.......... 53 كتور عبداله عطائى مصادر مساو ات در برابر قضاء سير تحول قضاءو مشروطيت در افغانستان........محمد ناصر حسن ز اده... 62 كاربرد قر اردادهاى اسلامى........................................

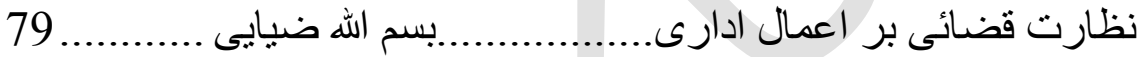

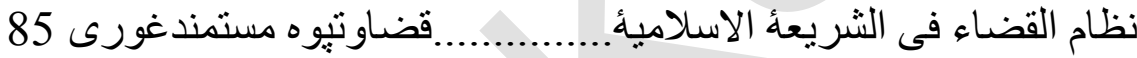

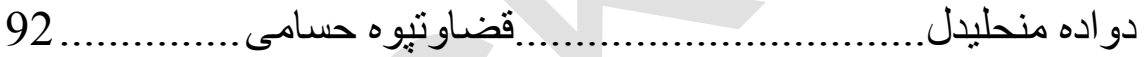

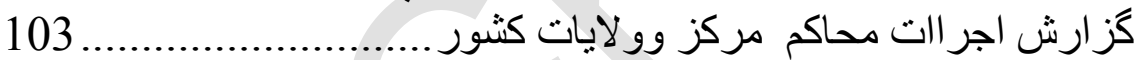

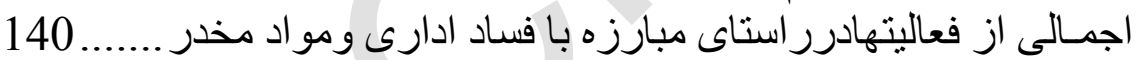

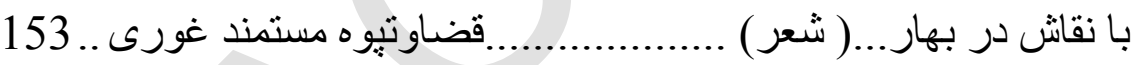


قُضاءع بيانيه رئيس ستره محكمه در مراسم افتتاح سيمينار عالى قضائى

بيانيه افتتاحيه واختتاميه رئيس ستره محكمه

در سيمينار عالى قضائى

منعقده 22- 25 حوت سئلمالئ 1395

بسم الله الرحمن الرحيم

بيانيه افتتاحيه:

الحمد لله رب العالمين و العاقبه للمتقين 
بيانيه رئيس ستره محكمه در مراسم افتتاح سيمينار عالى قضائى

\section{و الصلوه و السلام على خيرخلقه محمد وعلى إنى

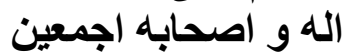

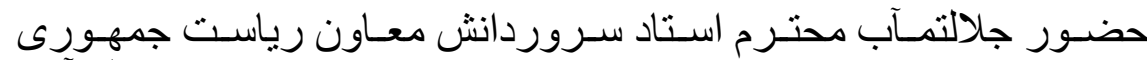

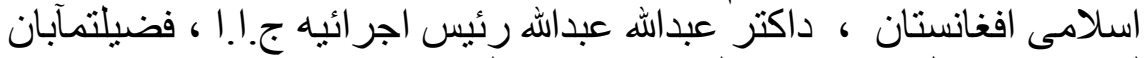

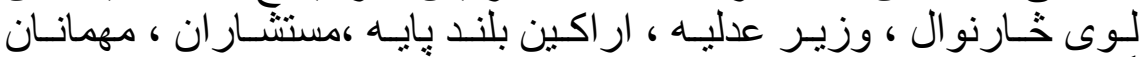

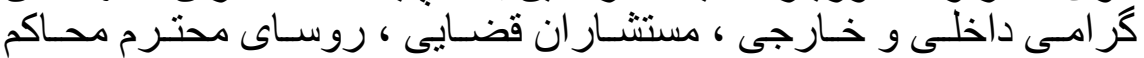

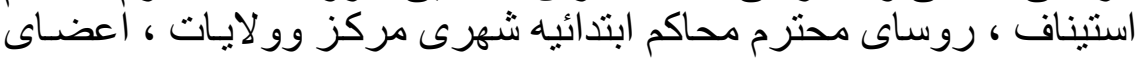

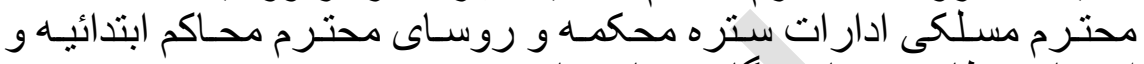

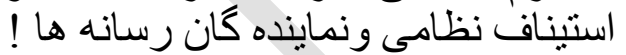
الســلام و علــــكم ورحمـــه الله

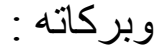

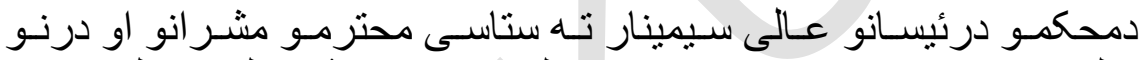

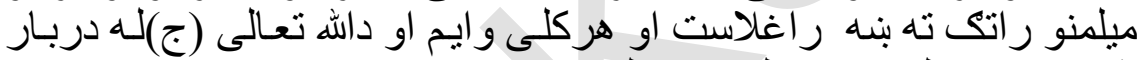

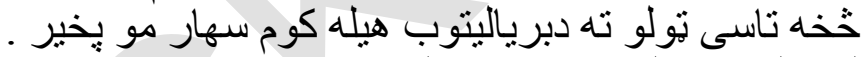

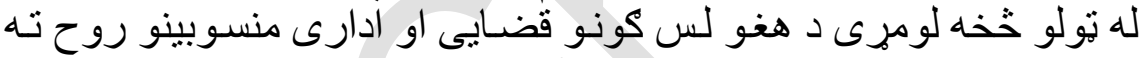

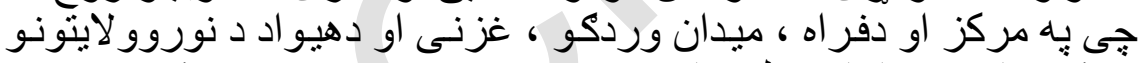

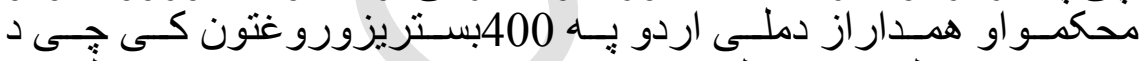

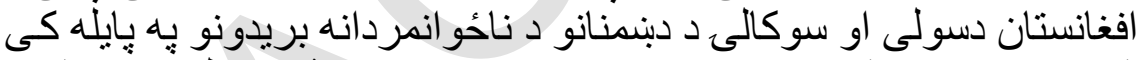

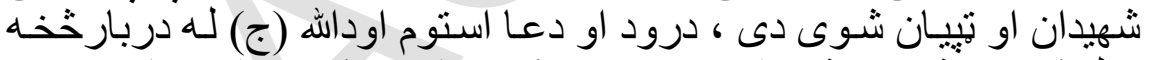

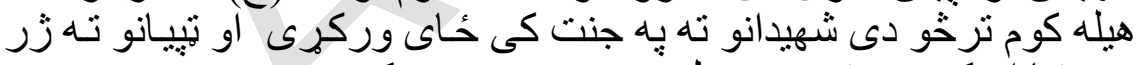

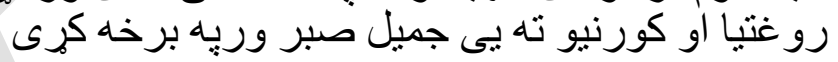

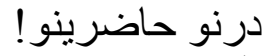

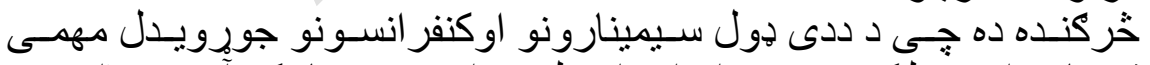

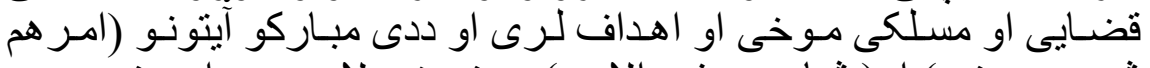

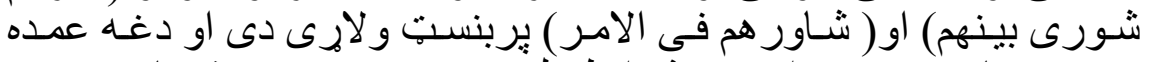

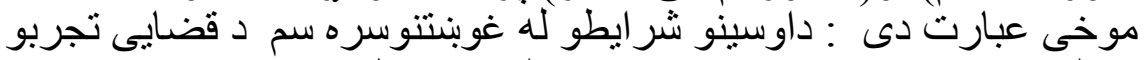

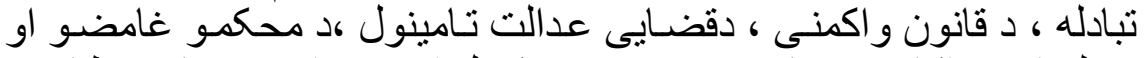

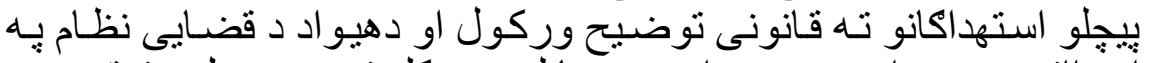

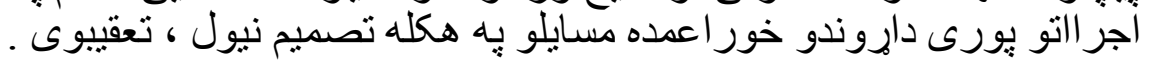




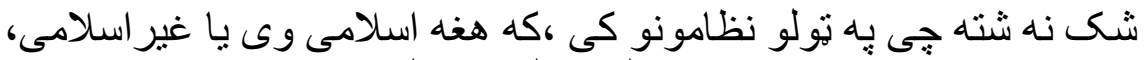

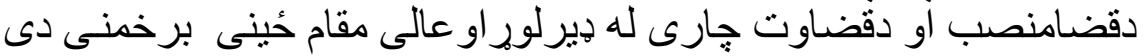

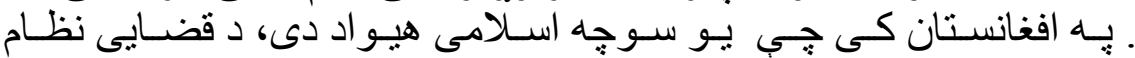

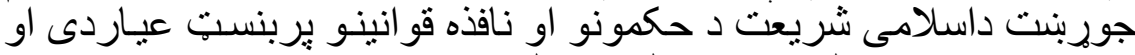

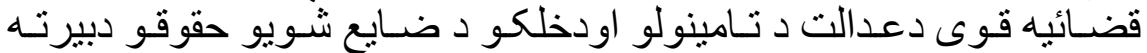

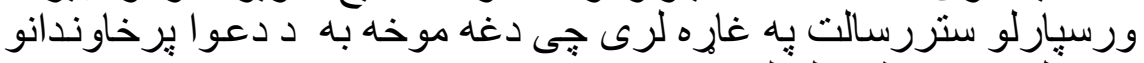

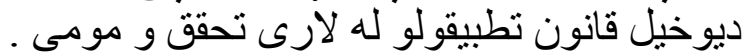

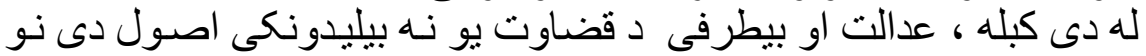

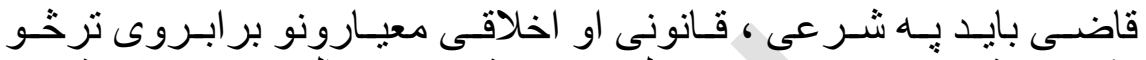

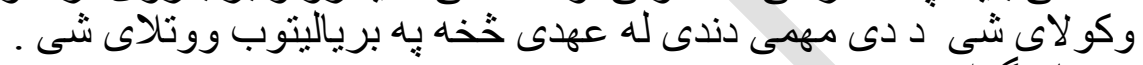

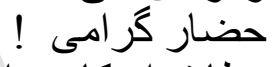

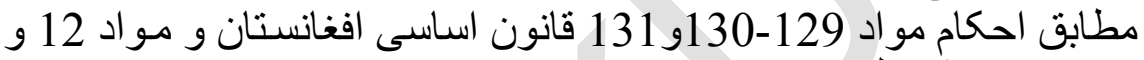

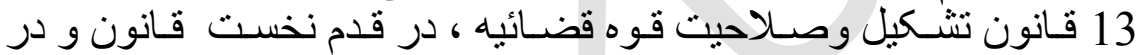

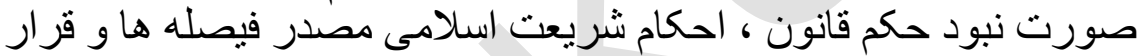

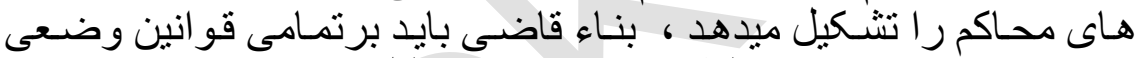

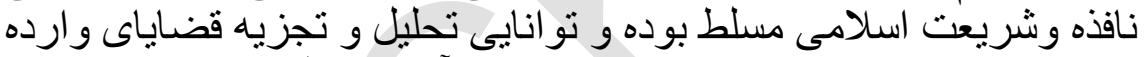

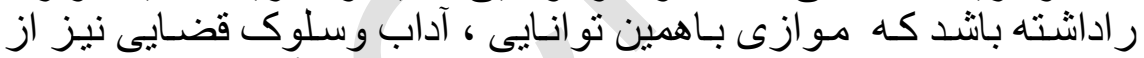

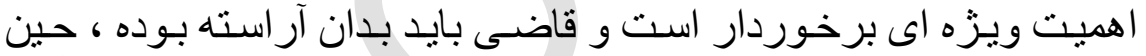

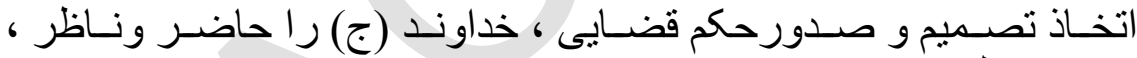

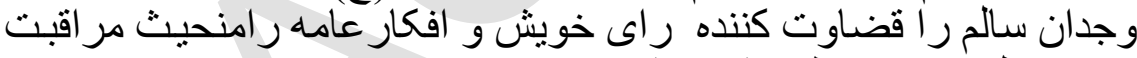

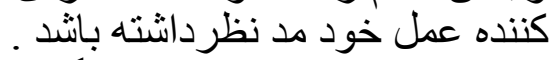

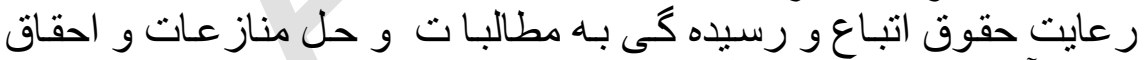

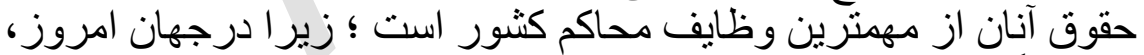

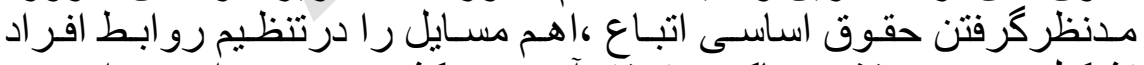

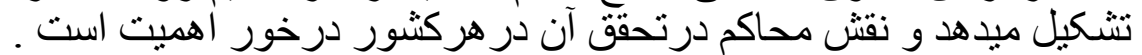

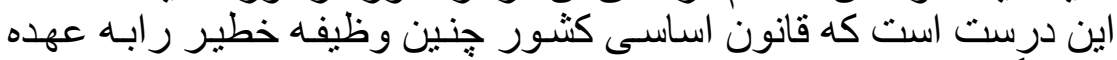

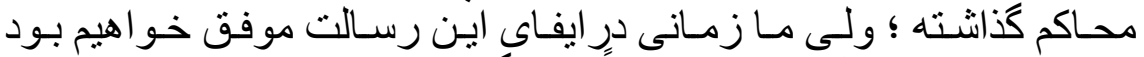

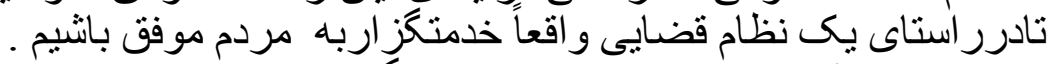

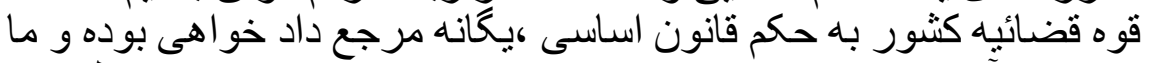

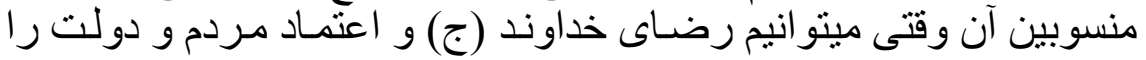


بيانيه رئيس ستره محكمه در مراسم افتتاح سيمينار عالى قضائى

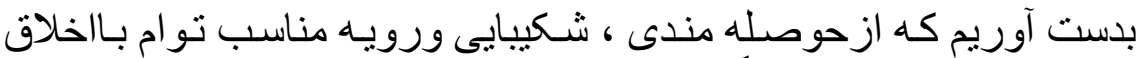

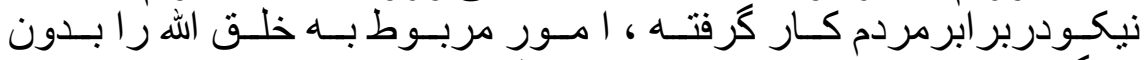

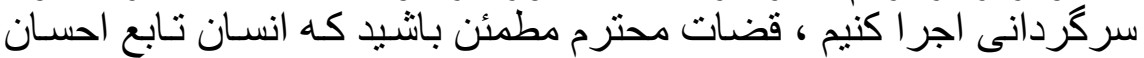

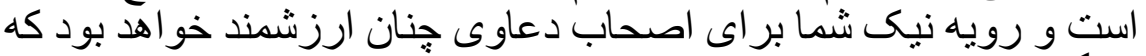

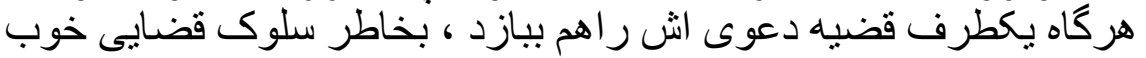

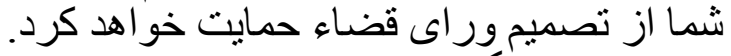

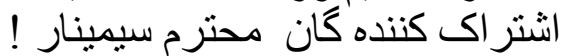

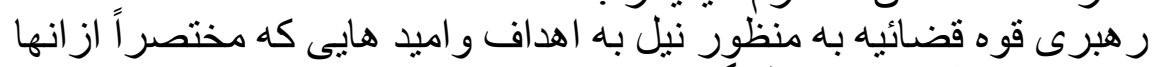

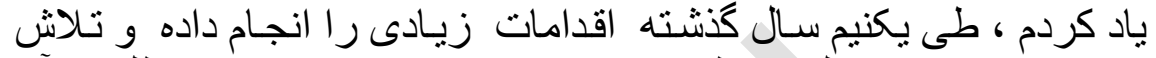

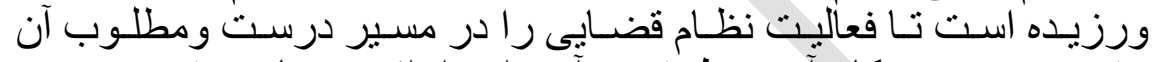

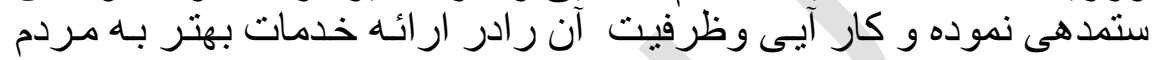

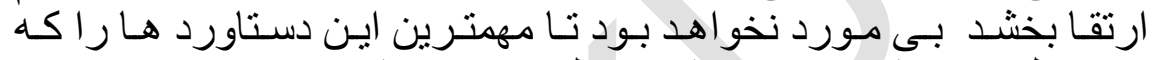

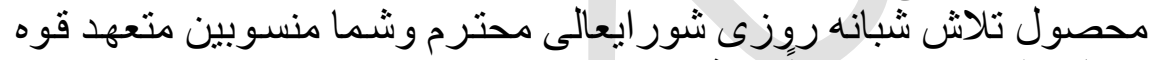

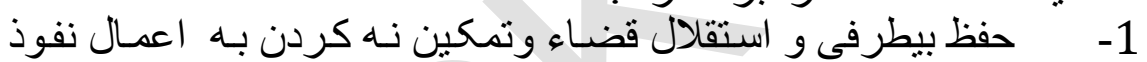

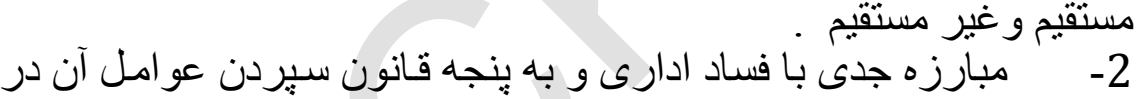

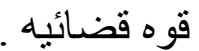
3- رسيده گیى به خو استهاى معقول و قانونى اصحاب دعاوى ازجانب

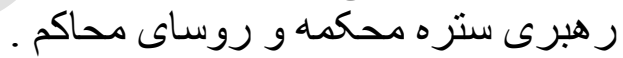

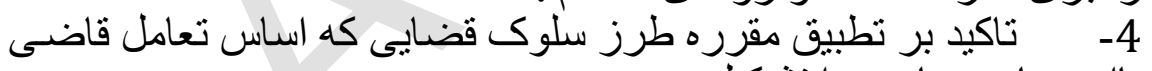

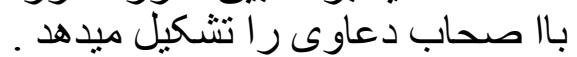

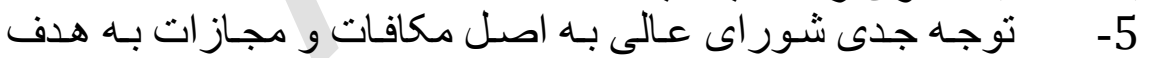

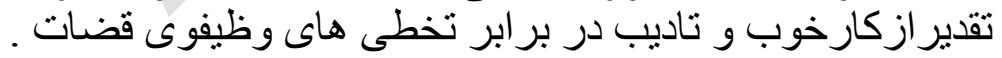

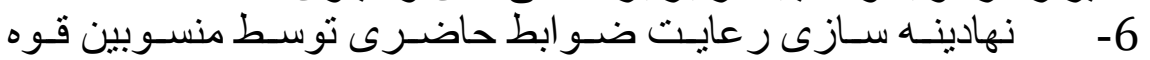

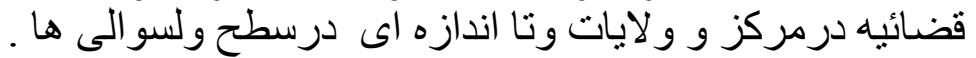

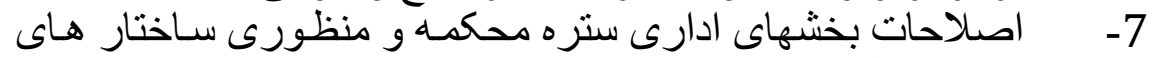
اصلاح شده درسالجارى ازجانب مقام عالى رياست جمهورى و ادامـا اين اين

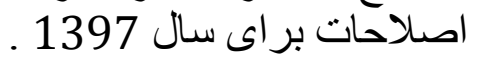


بياتيه رئيس ستره محكمه در مراسم افتتاح سيمينار عالى قضائى

\section{قضاء}

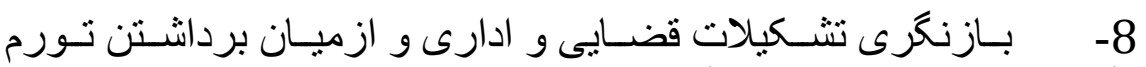

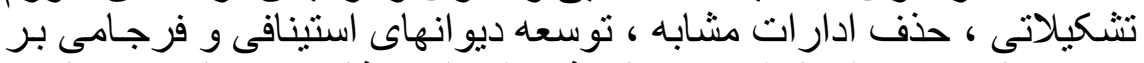

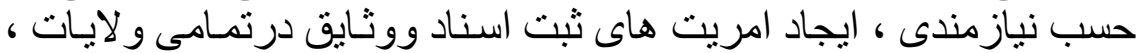

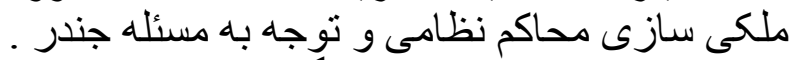

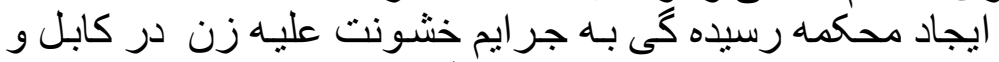

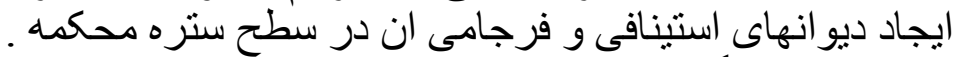

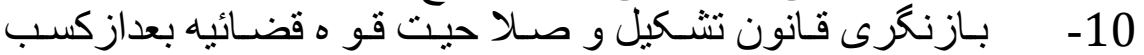

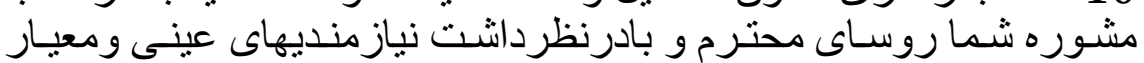

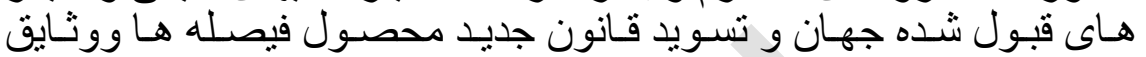

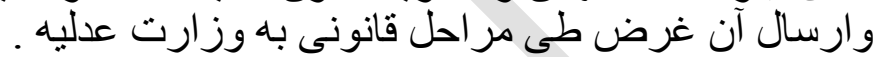

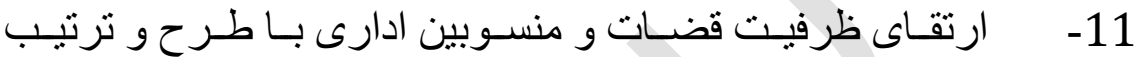

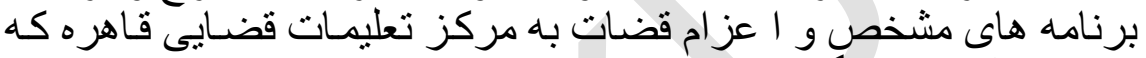

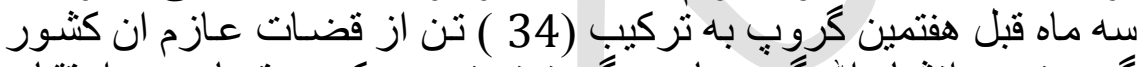

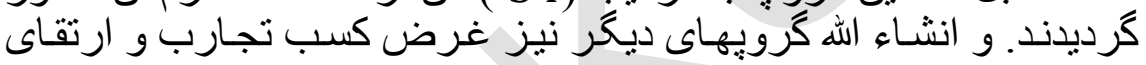
سطح دانش اعز ام خو اهند شند أند

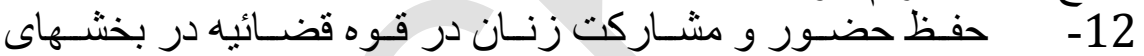

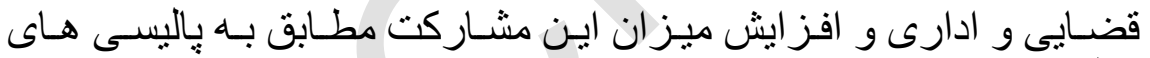
دولت

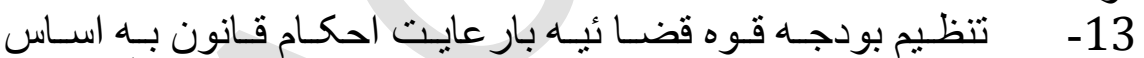

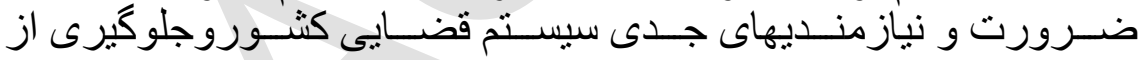

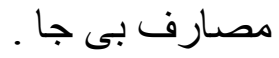

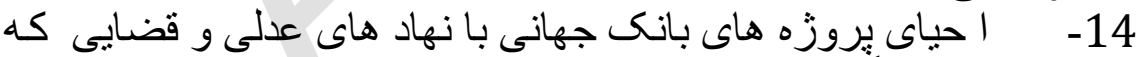

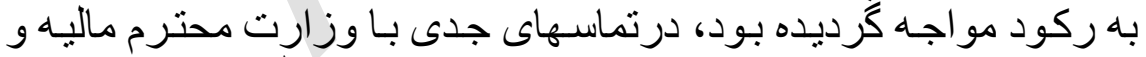

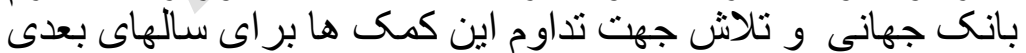

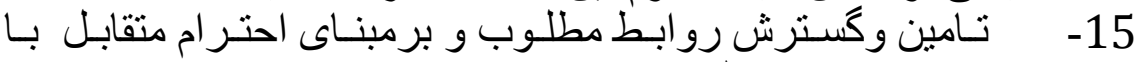

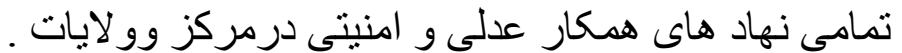

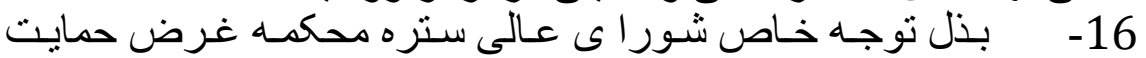

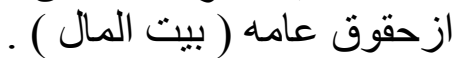
17- مفانعت قضضات برحال از انتخال به غير ازوظايف قضايى. 


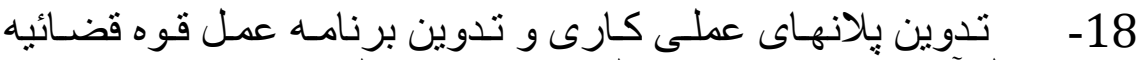

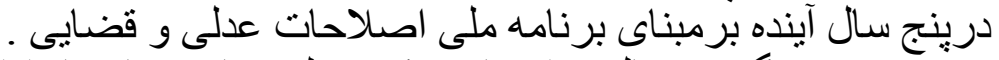

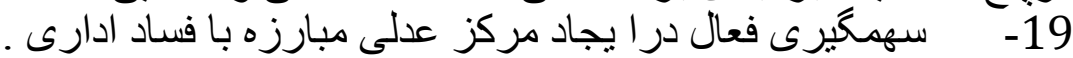

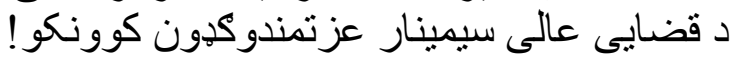

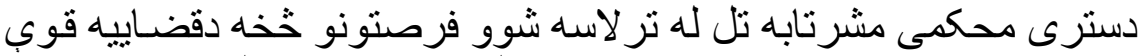

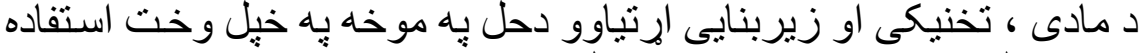

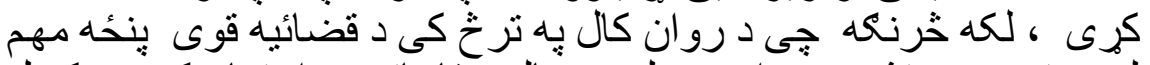

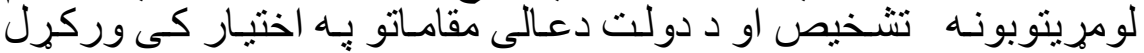

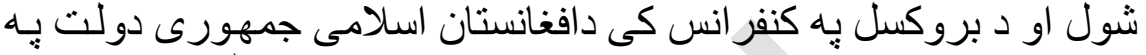

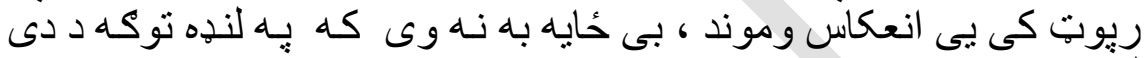

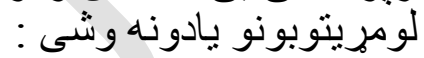

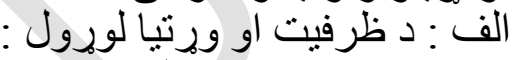

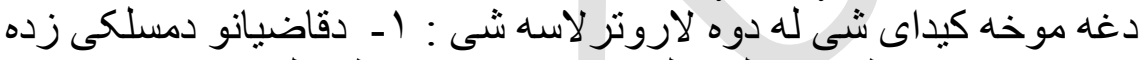

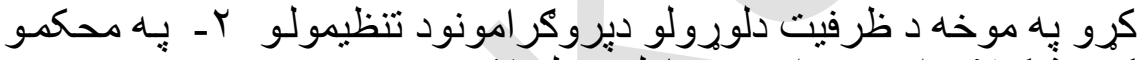

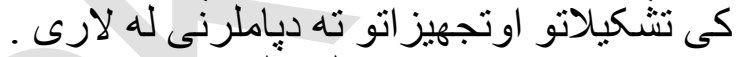

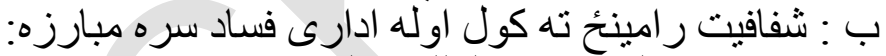

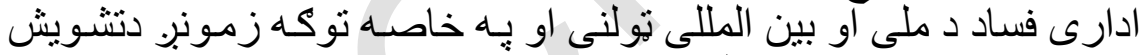

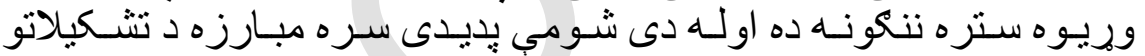

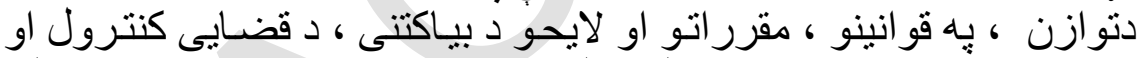

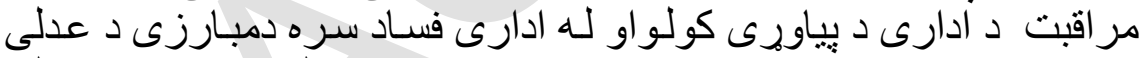

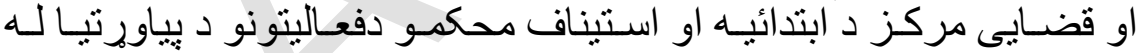

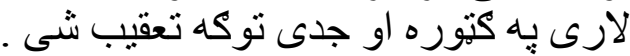

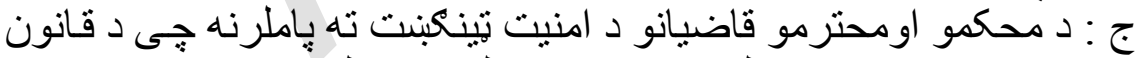

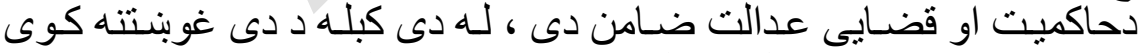

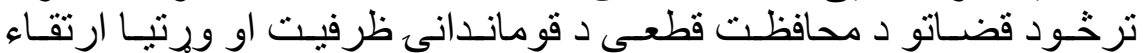

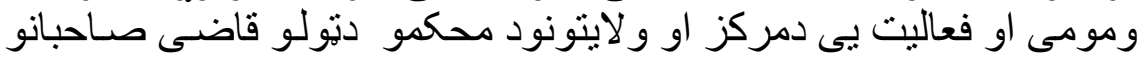

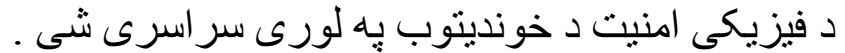

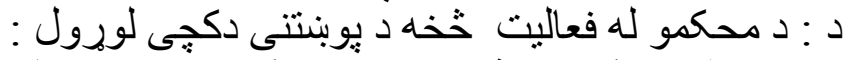

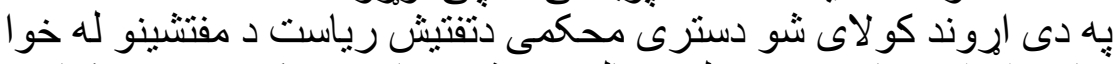

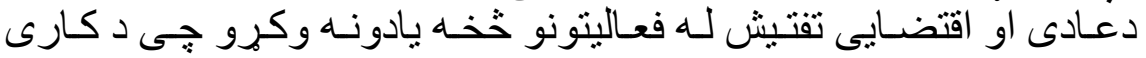




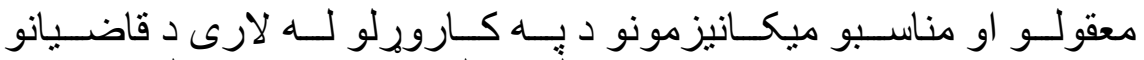

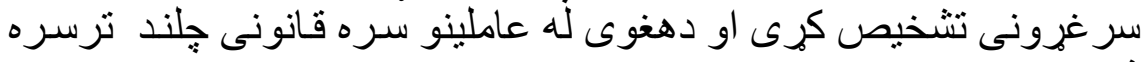
هـ : دمحاكمو ودانيوته بِاملرنه :

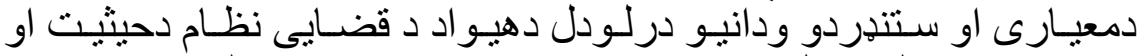

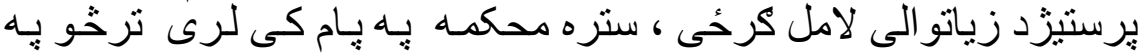

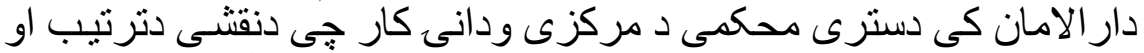

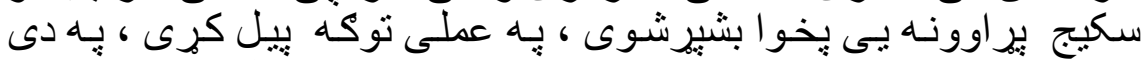

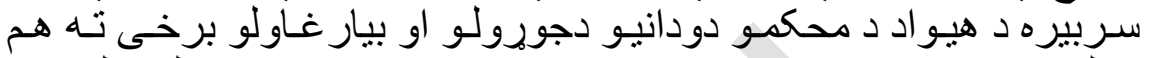

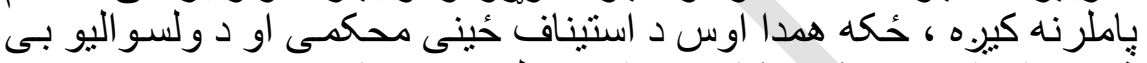

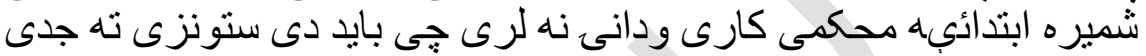

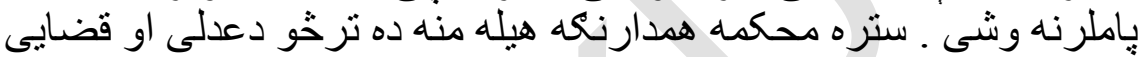

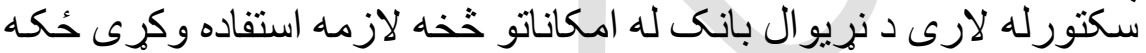

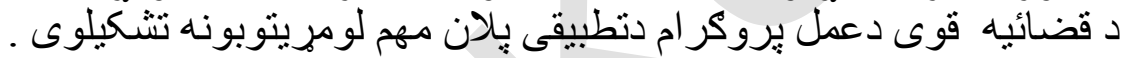

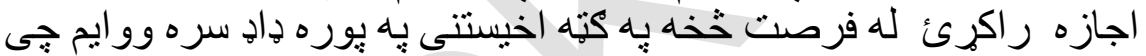

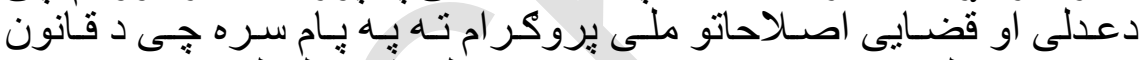

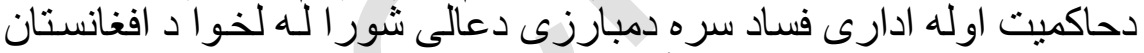

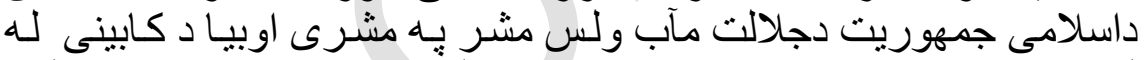

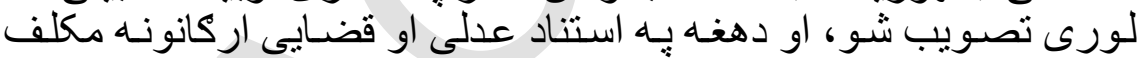

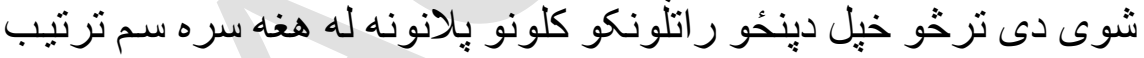

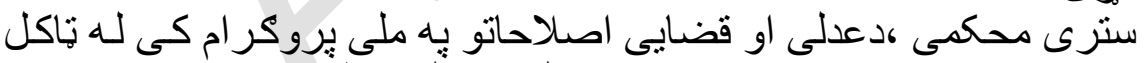

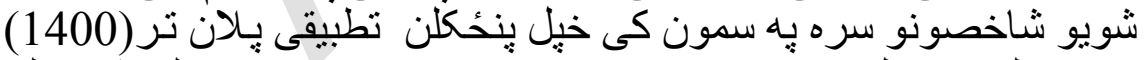

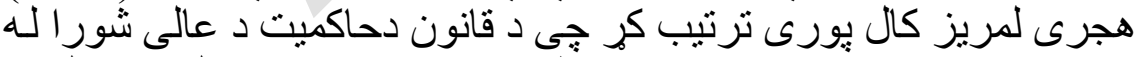

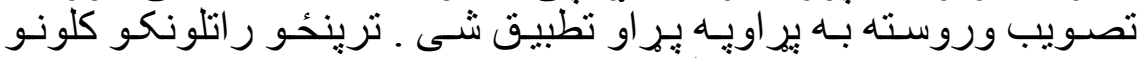

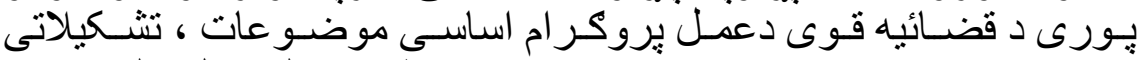

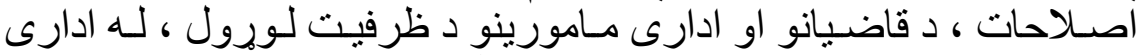

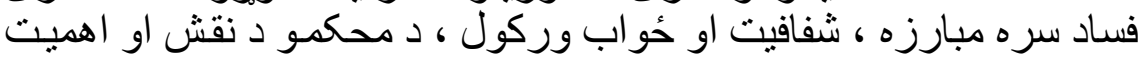

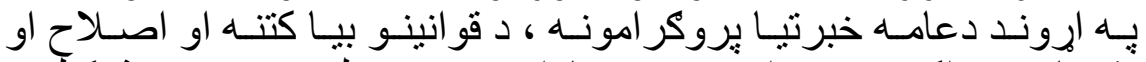

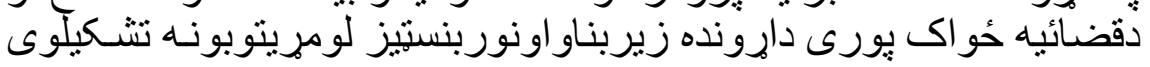


بيانيه رئيس ستره محكمه در مراسم افتتاح سيمينار عالى قضائى

قضاء

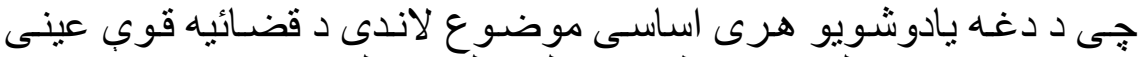

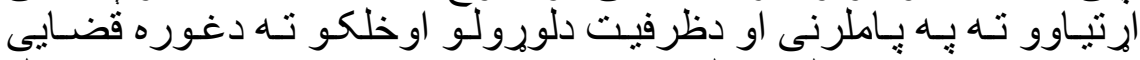

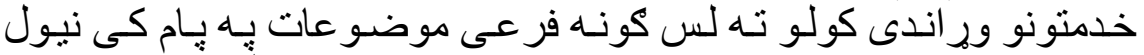

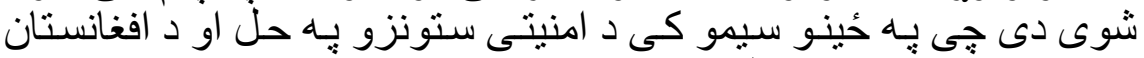

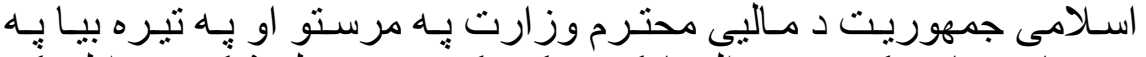

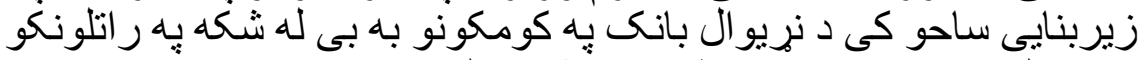

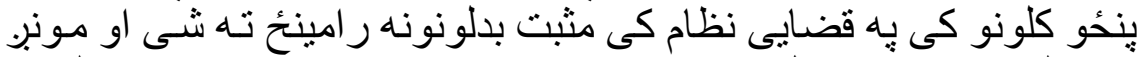

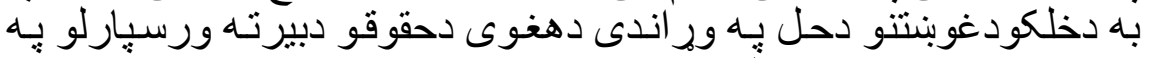

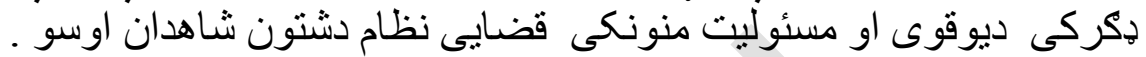

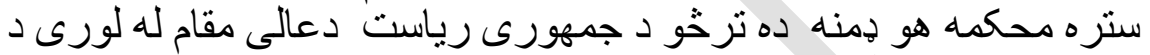

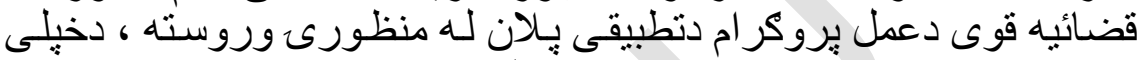

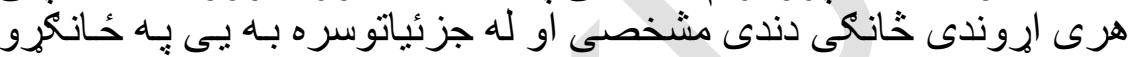

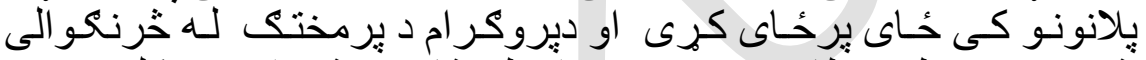

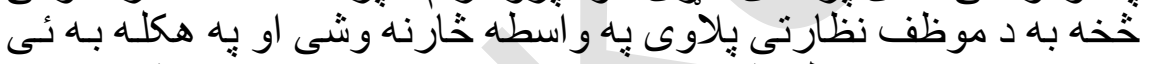

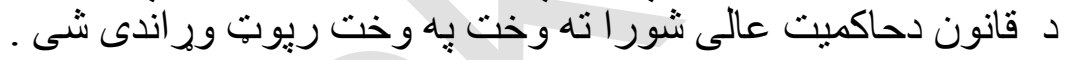

\section{حضار كرامى و روساى محترم محاكم!}

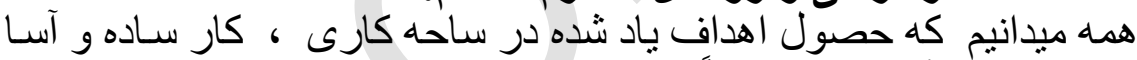

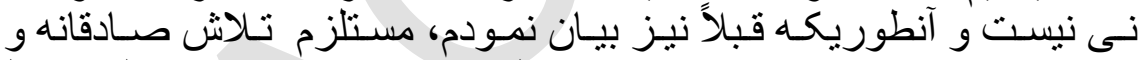

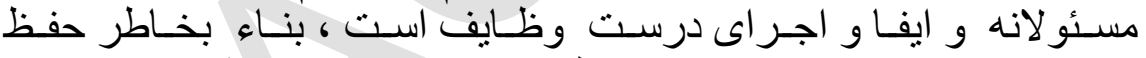

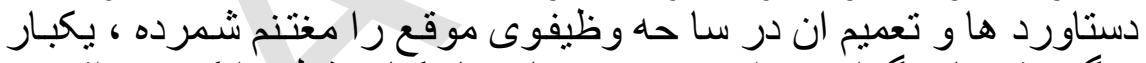

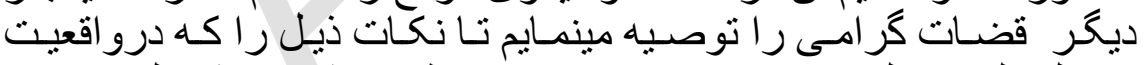

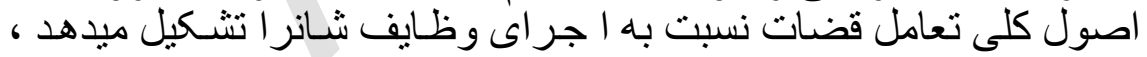

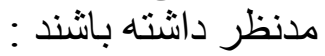

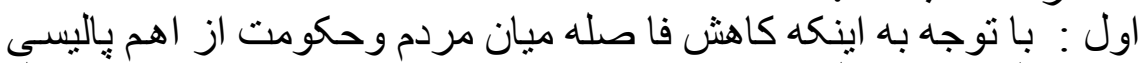

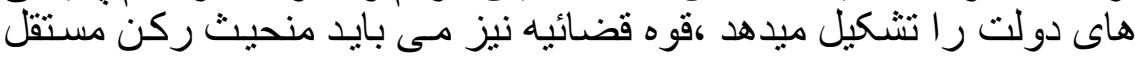

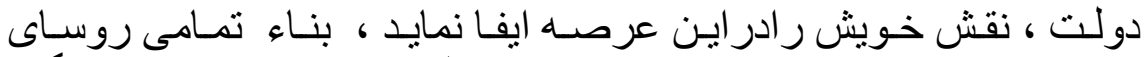

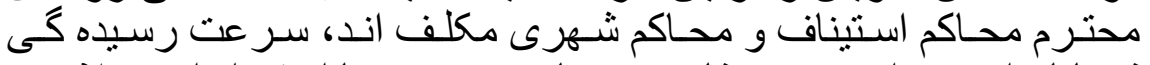

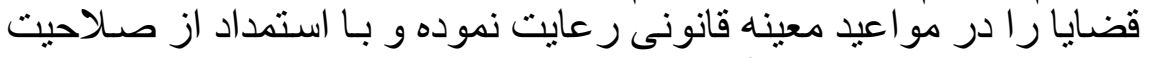

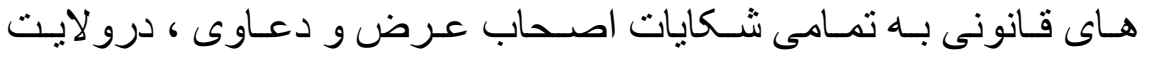


بيانيه رئيس ستره محكمه در مراسم افتتاح سيمينار عالى قضانى

وولسو الى هاى مربوط خويش رسيده گى جدى به عمل آورند ؛ زير ا قانون

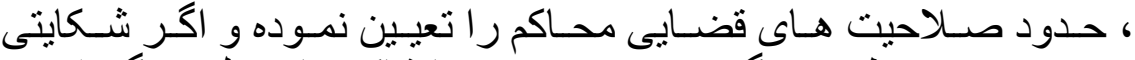

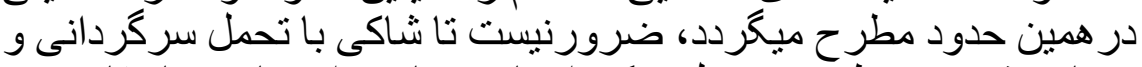

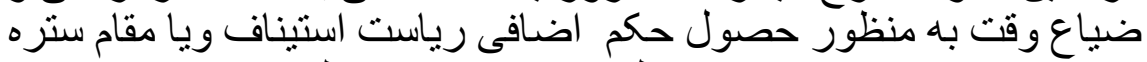

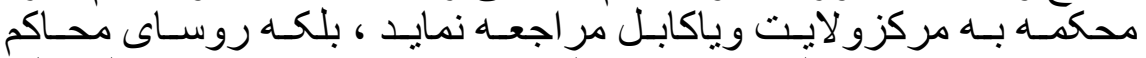

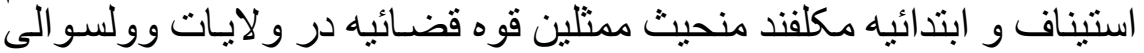

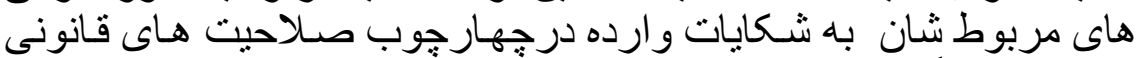

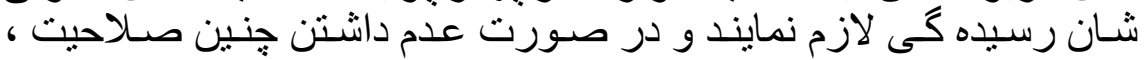

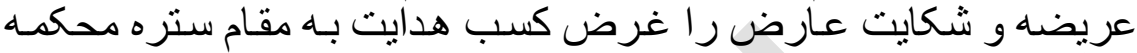

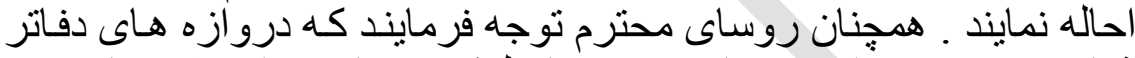

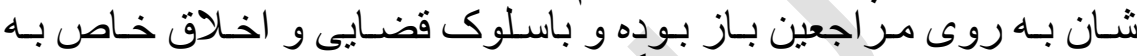

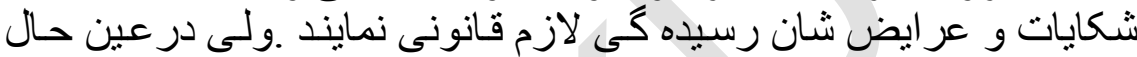

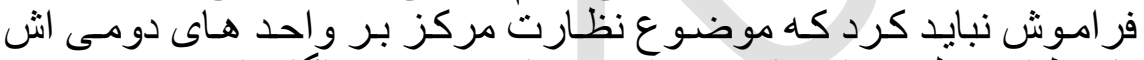

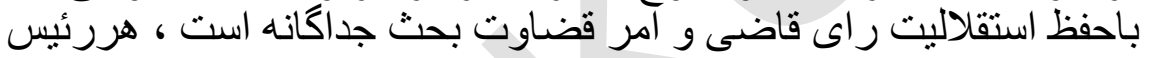

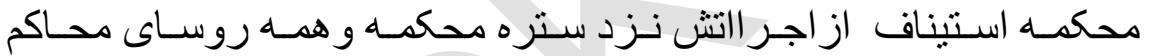

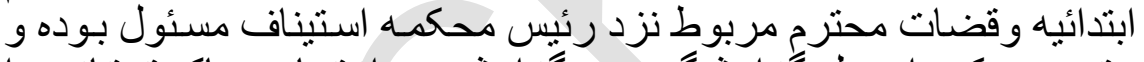

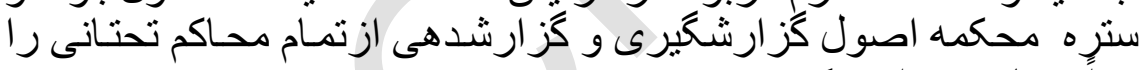

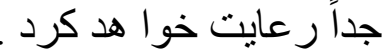
دوم : تامين رو ابط محاكم استيناف با مقام و لايت و ساير نهاد هاد هاى عدلى ولى و

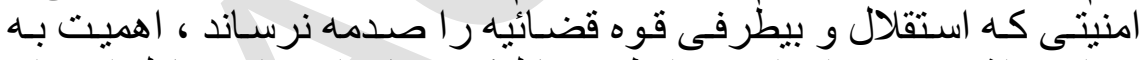

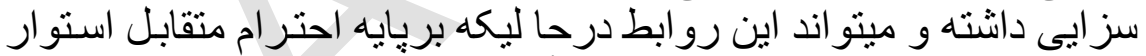

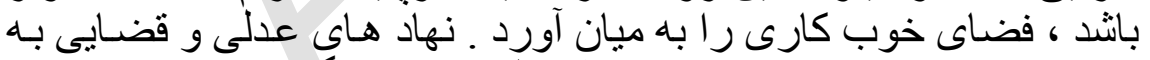

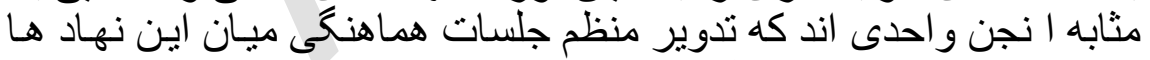

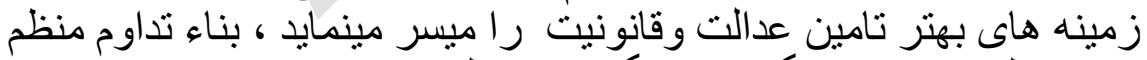

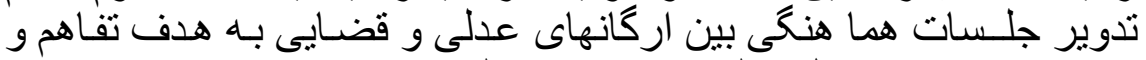

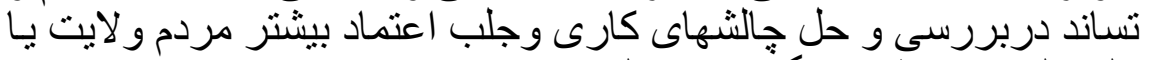

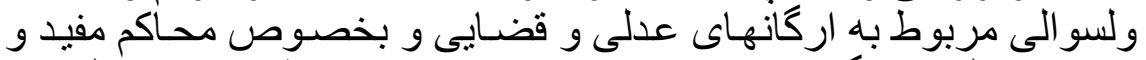

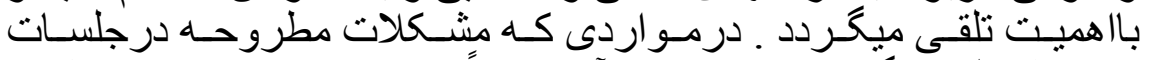

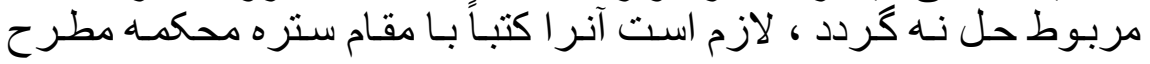


بيانيه رئيس ستره محكمه در مراسم افتتاح سيمينار عالى قضانى

نموده تا ازطريق كميته عدلى و قضايى وياهم شور اى عالى حاكميت قانون

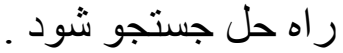

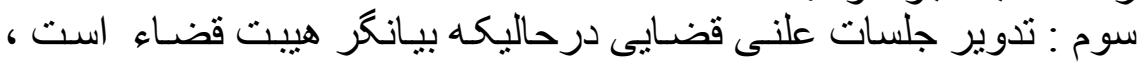

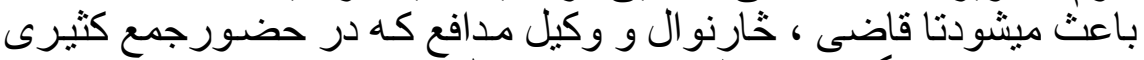

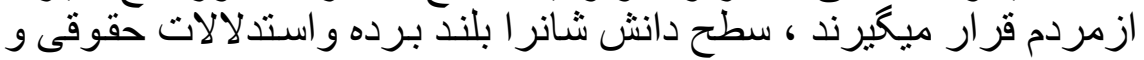

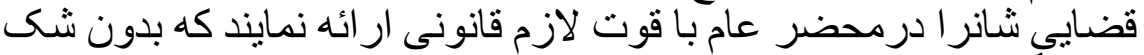

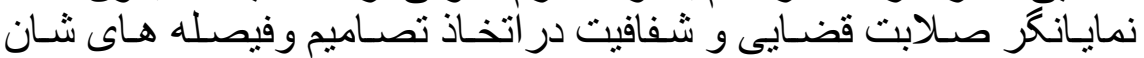

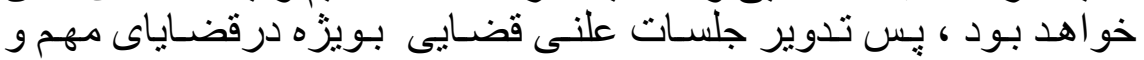

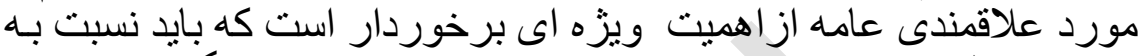

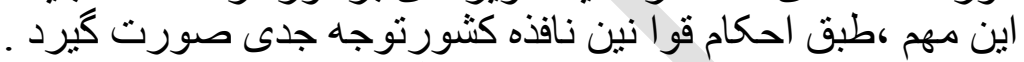

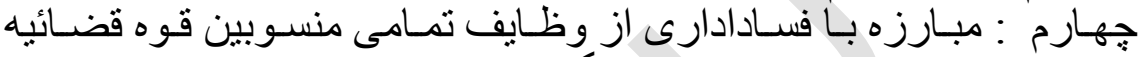

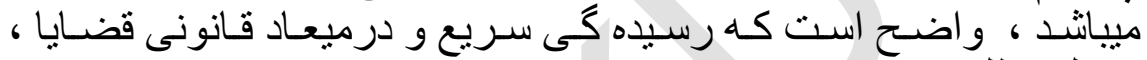

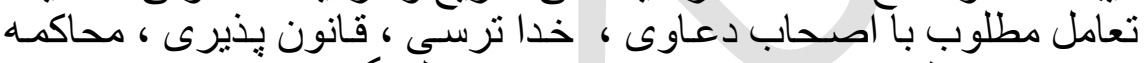

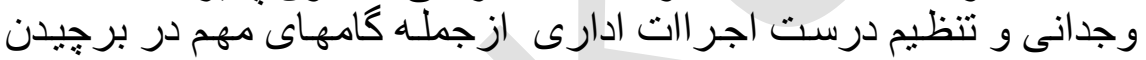

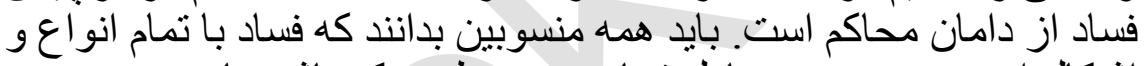

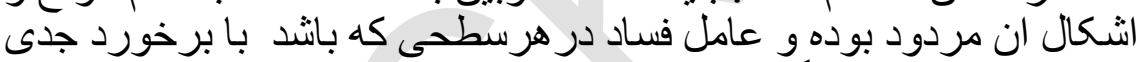

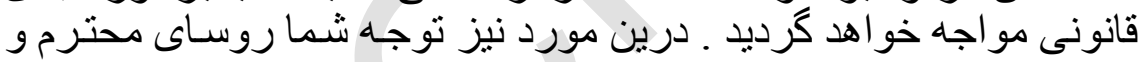

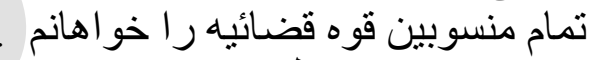

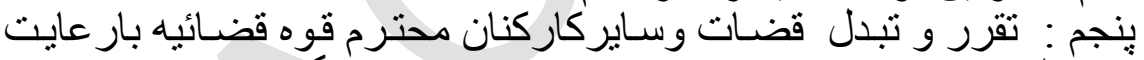

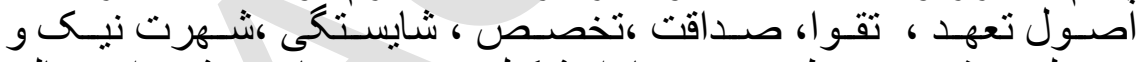

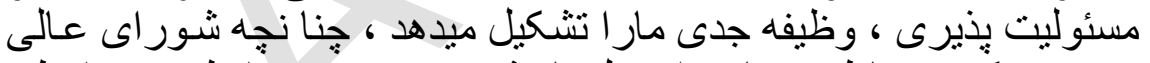

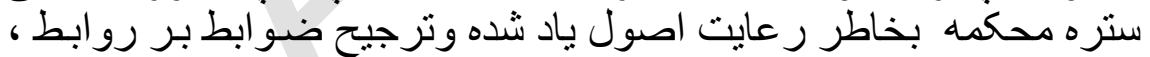

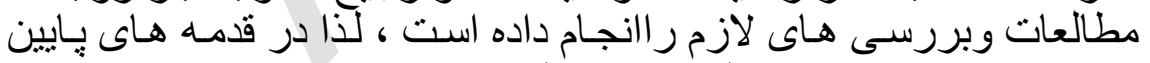

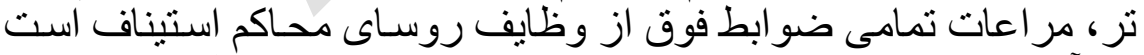

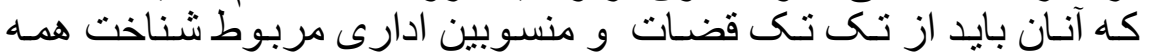

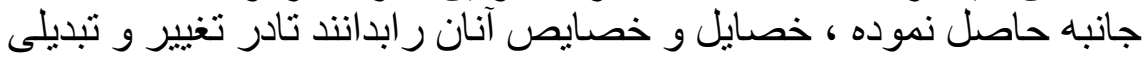

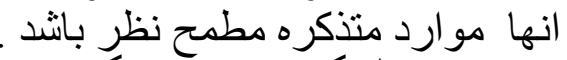

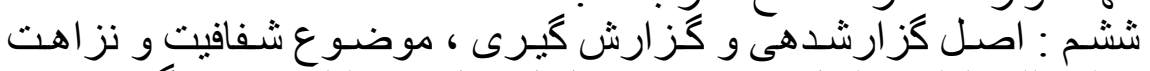

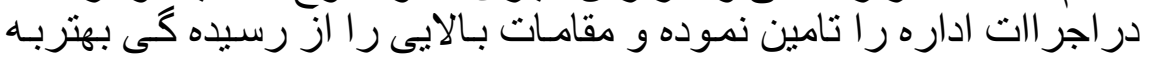

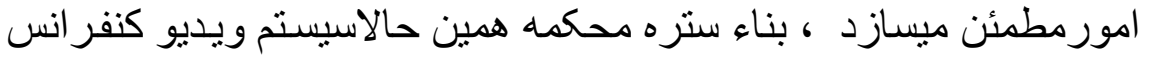


بيانيه رئيس ستره محكمه در مراسم افتتاح سيمينار عالى قضانى

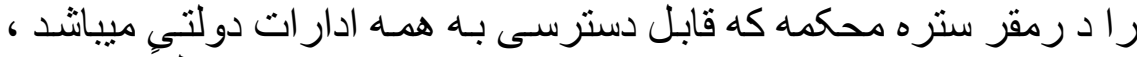

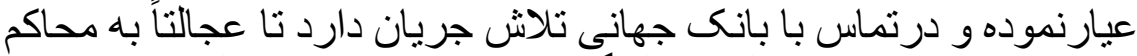

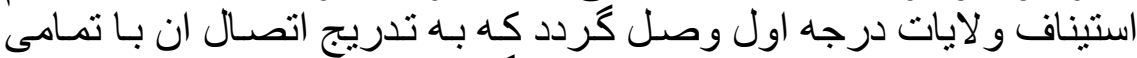

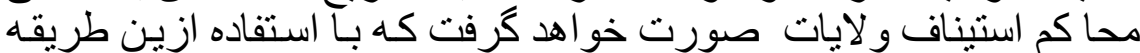

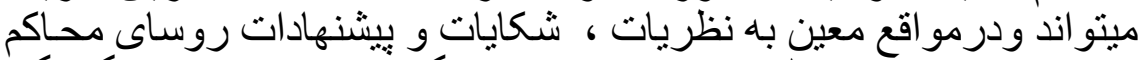

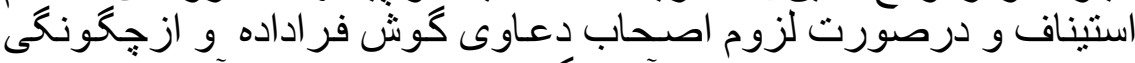

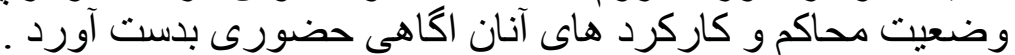

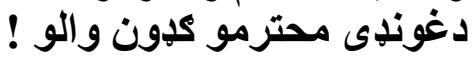

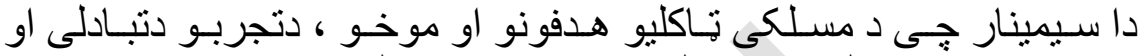

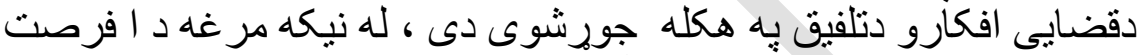

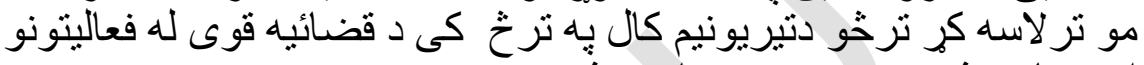

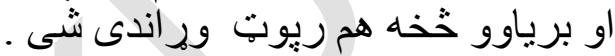

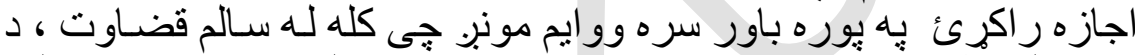

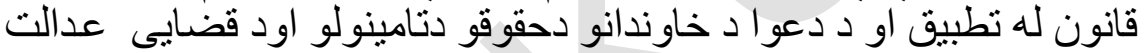

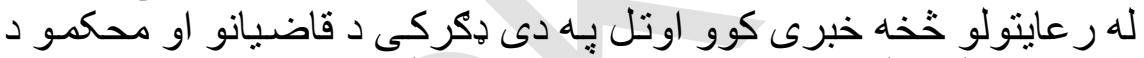

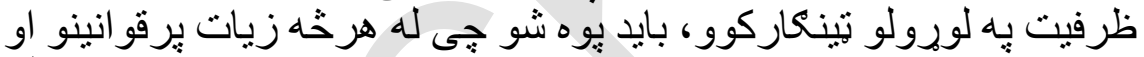

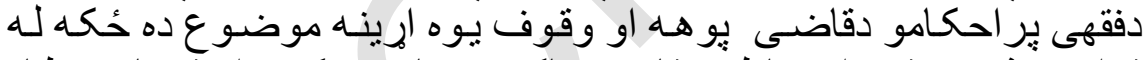

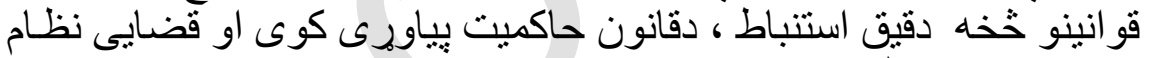

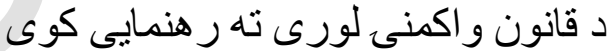

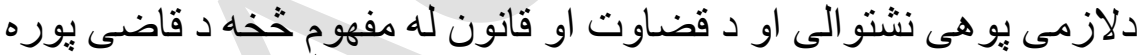

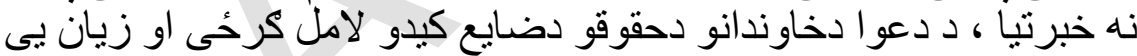

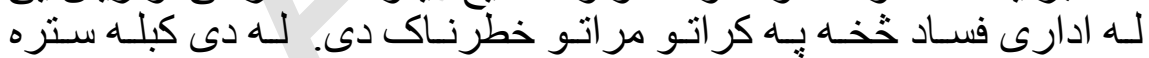

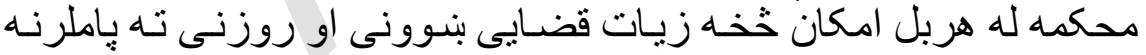

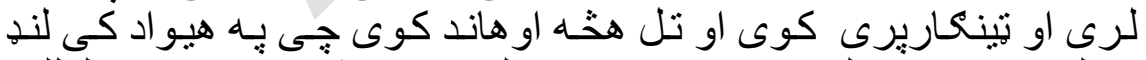

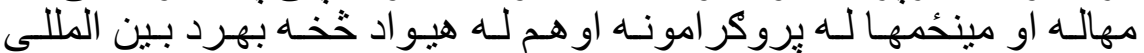

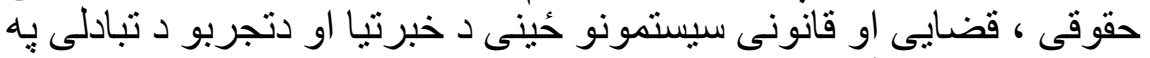

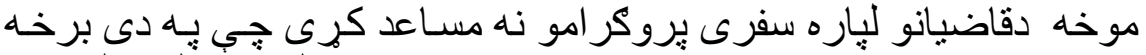

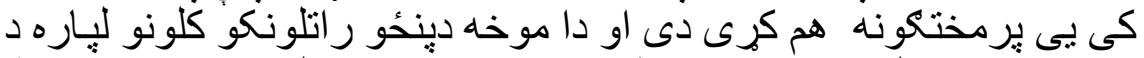

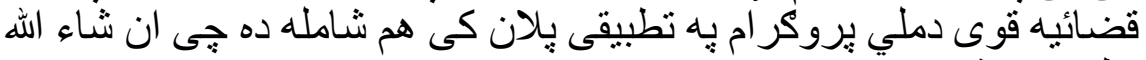

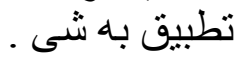


بيانيه رئيس ستره محكمه در مراسم افتتاح سيمينار عالى قضائى

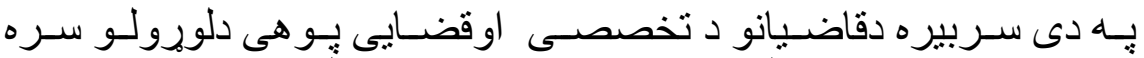

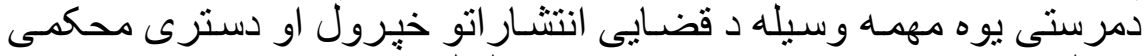

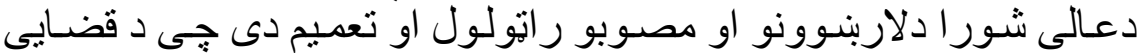

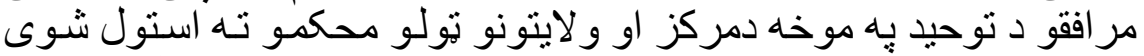

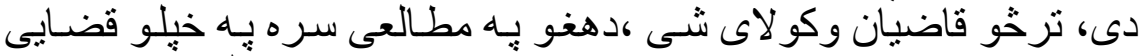

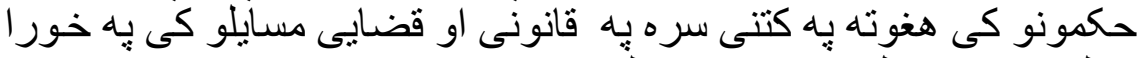

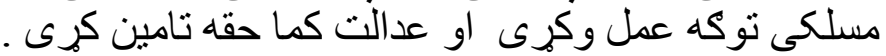

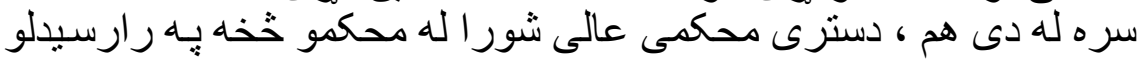

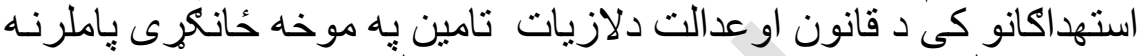

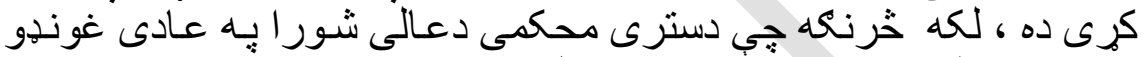

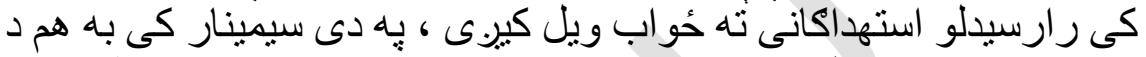

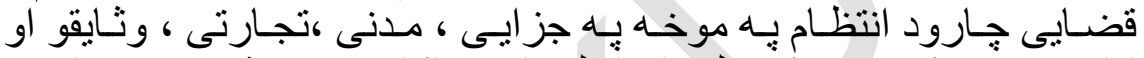

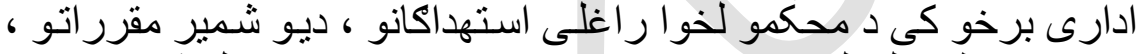

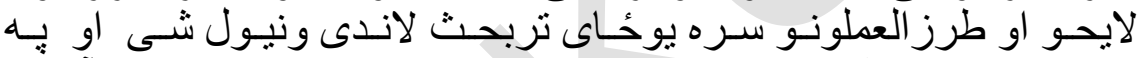

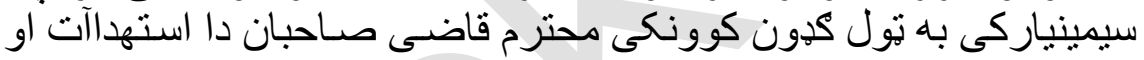

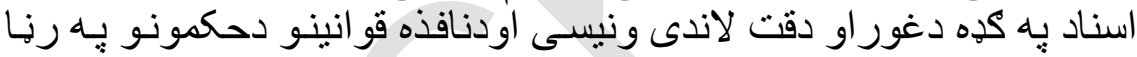

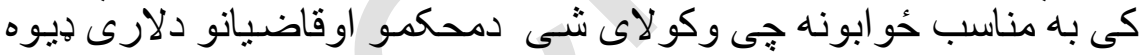

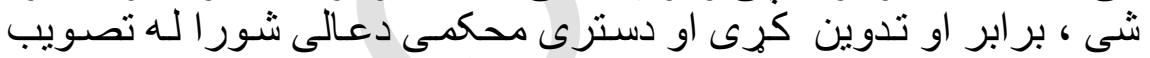

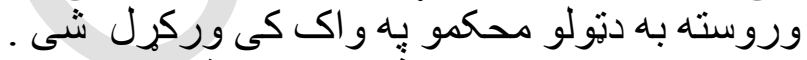

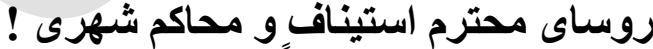

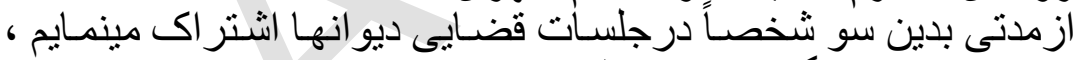

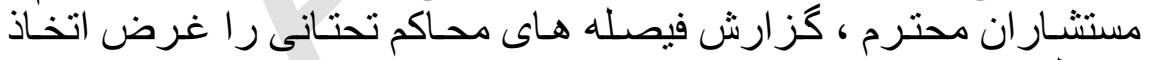

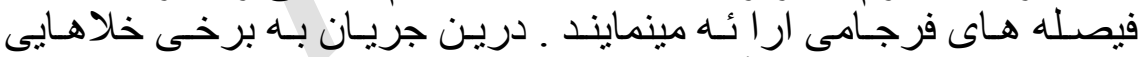

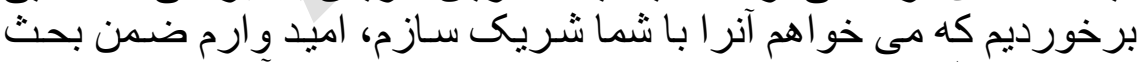

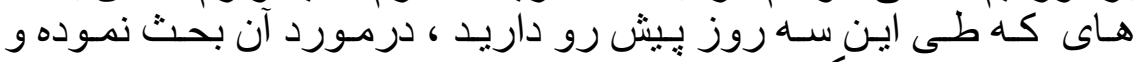

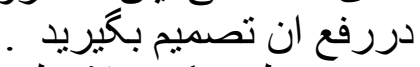

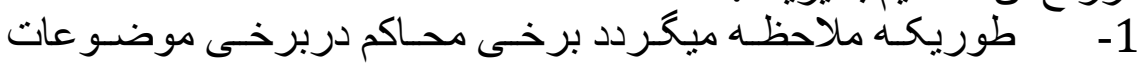

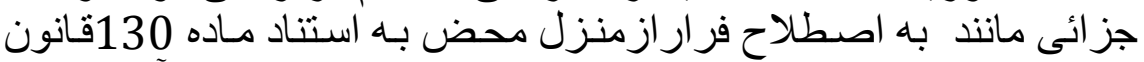

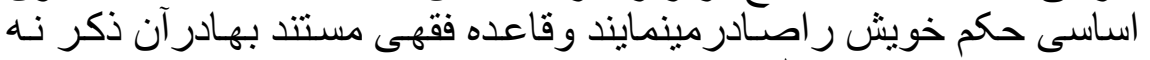

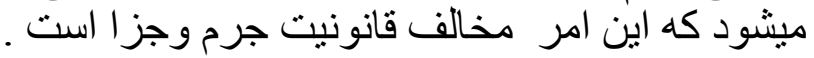




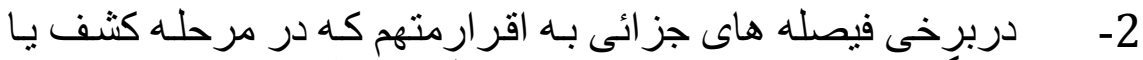

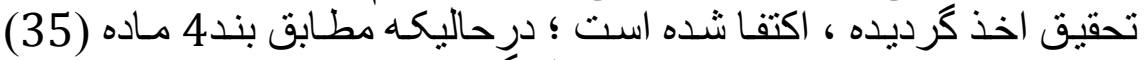

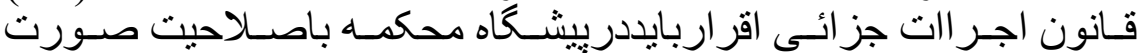

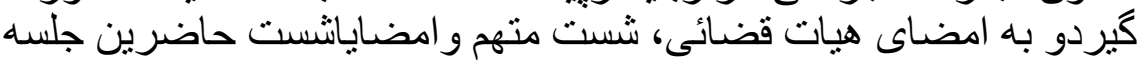

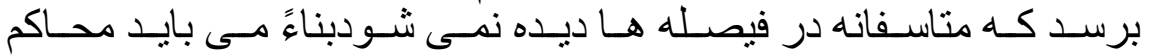
درموردتوجه جدى نمايند.

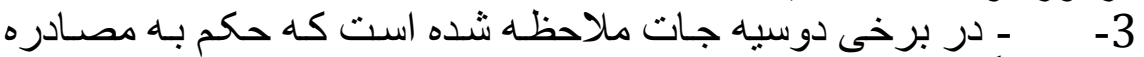

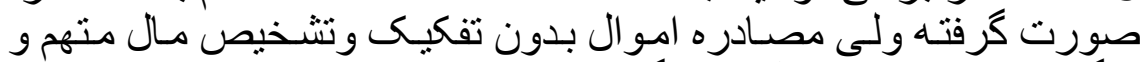

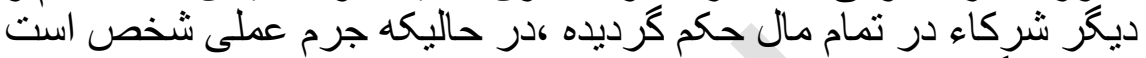

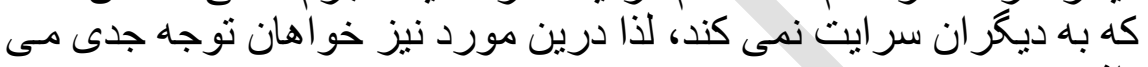

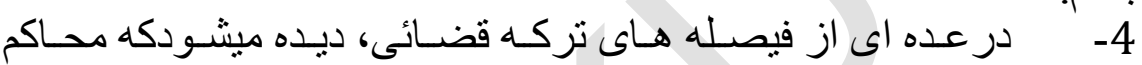

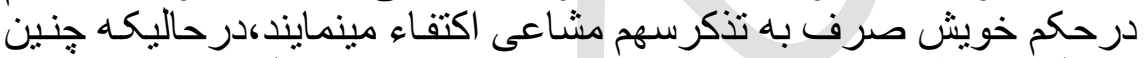

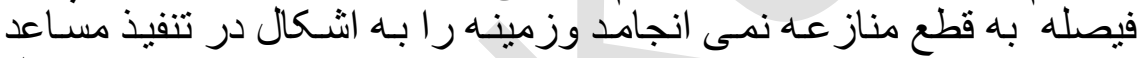

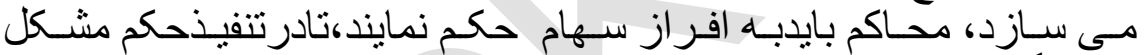

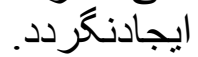

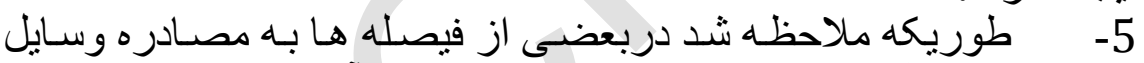

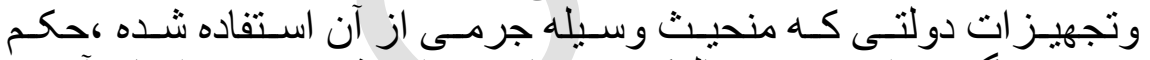

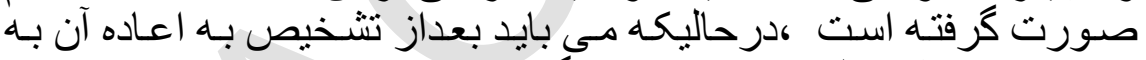

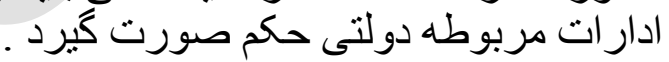

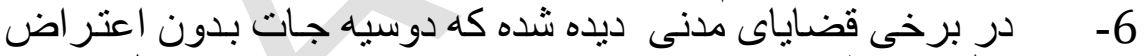

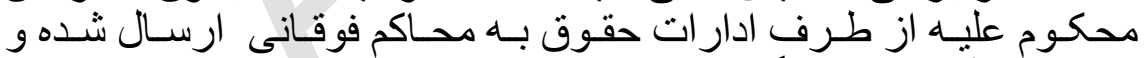

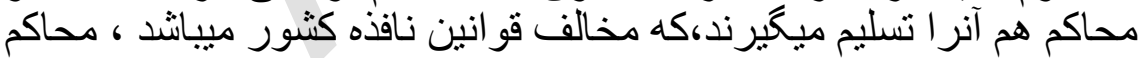
در مورد نوجه نمايند.

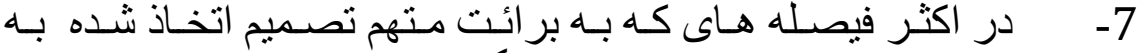

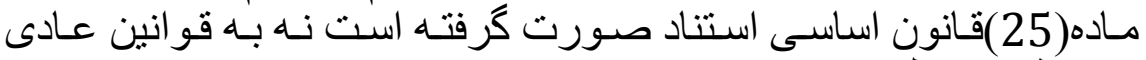

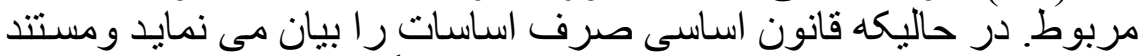

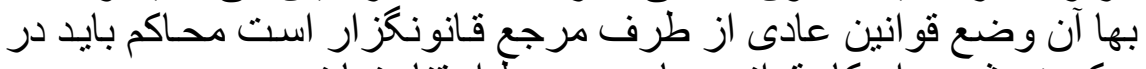
حكم خويش به احكام قو انين عادى مربوط است استناد نمايند. 


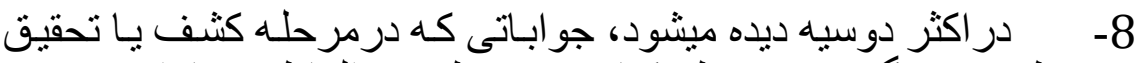

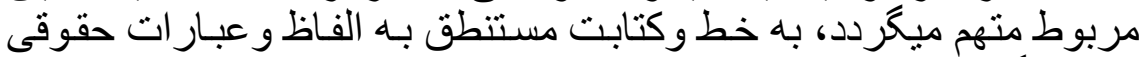

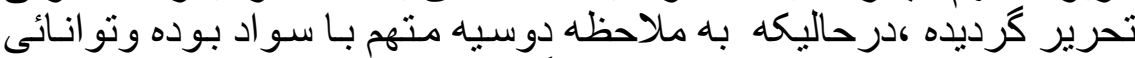

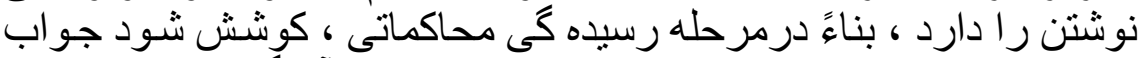

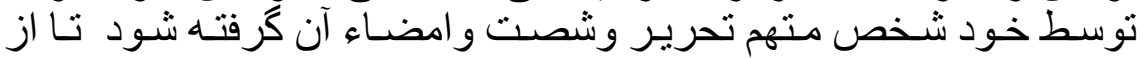

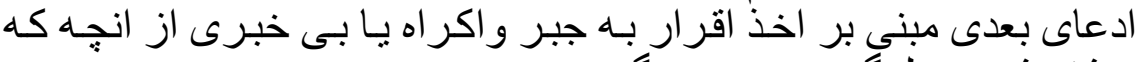

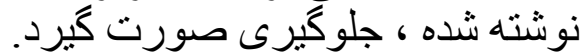

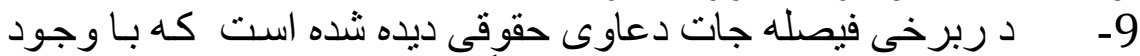

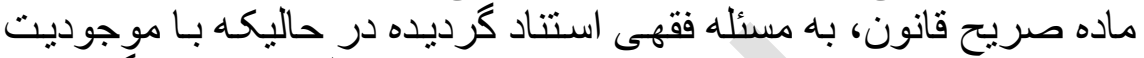

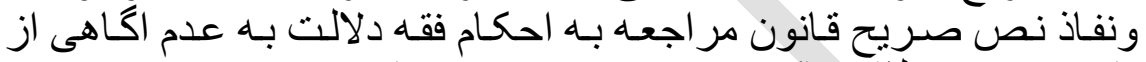

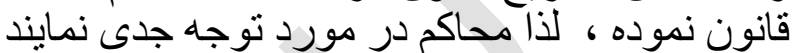

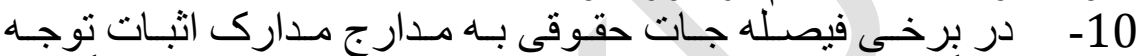

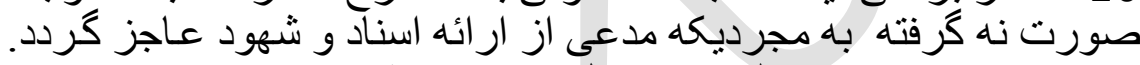

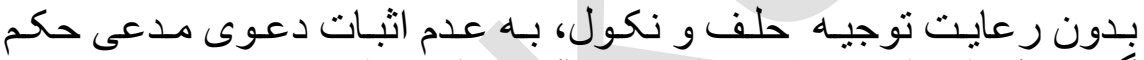

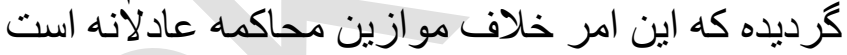

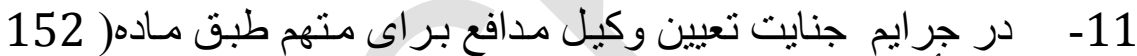

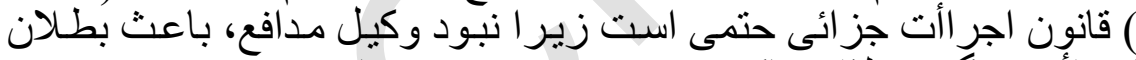

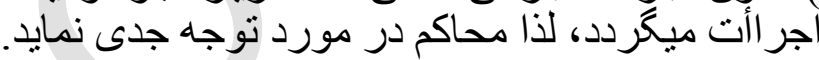

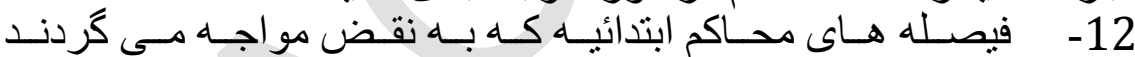

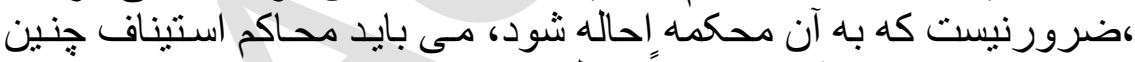

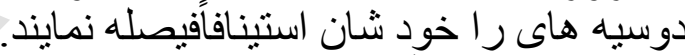

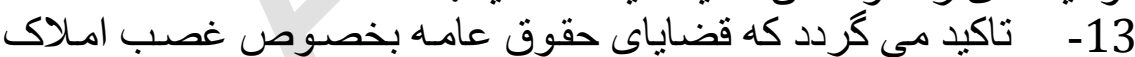

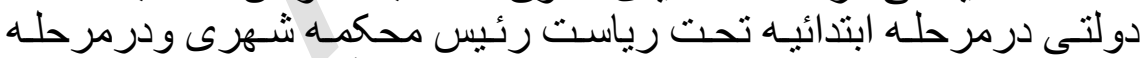

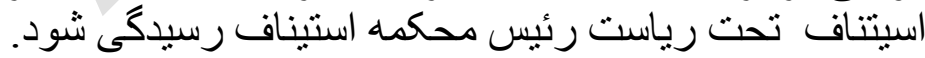

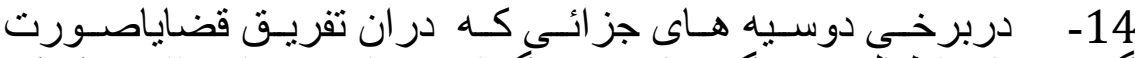

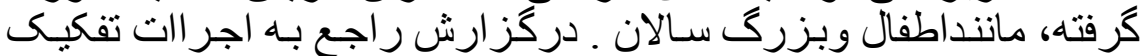

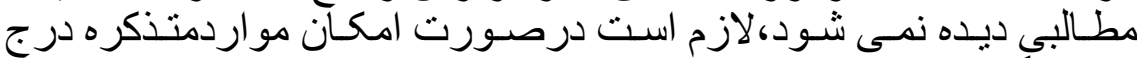
دوسيه كردد . دمه د. 
بيانيه رئيس ستره محكمه در مراسم افتتاح سيمينار عالى قضائى

قضاء

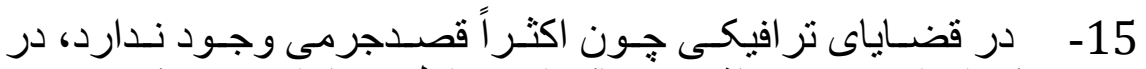

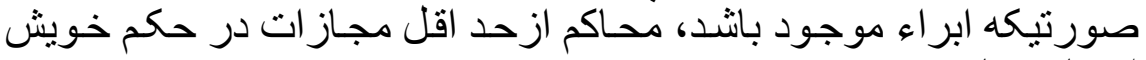

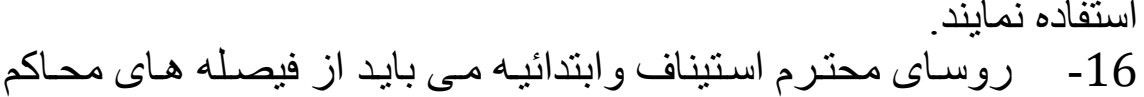
تحتانى نظارت دو امدار نمايند.

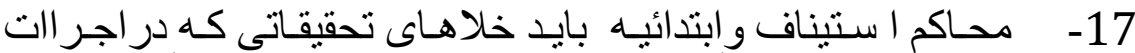

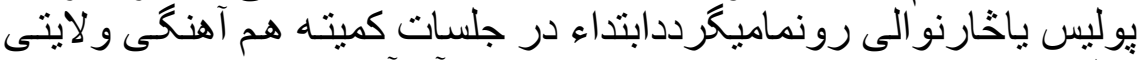

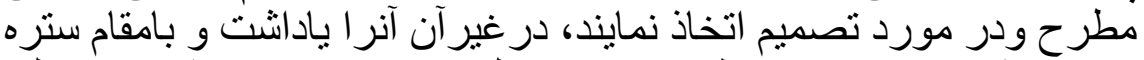

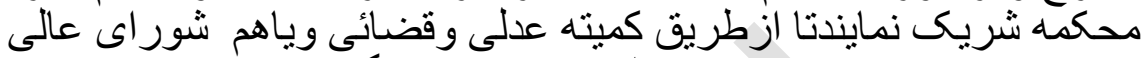

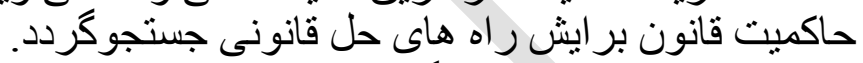

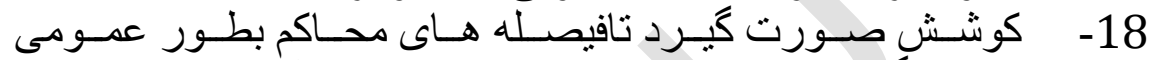

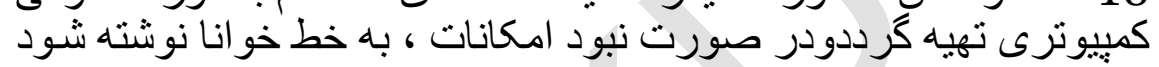

19- مستشار ان محترم قضائى در وقت تحليل وارزيابى دوسيه تنتها بـهـ

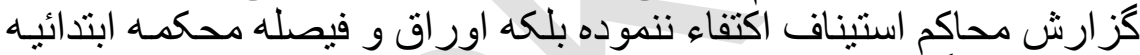

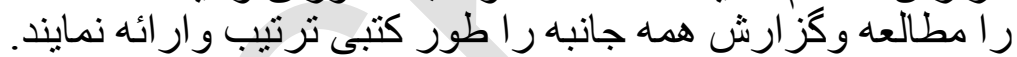

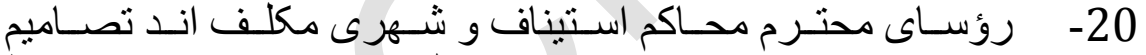

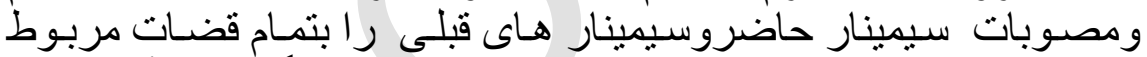

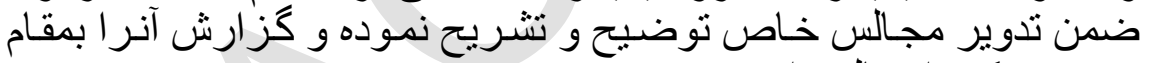
ستره محكمه ارسال بدارند.

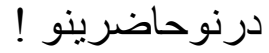

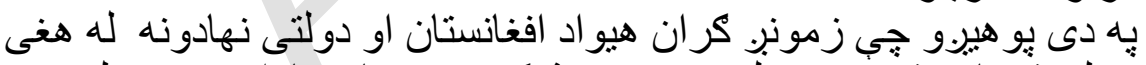

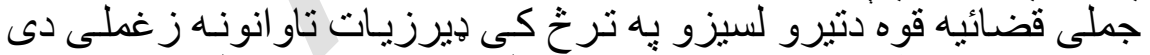

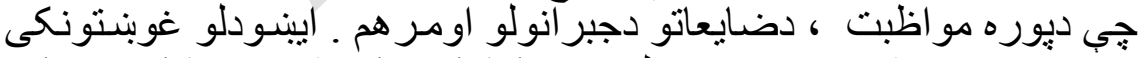

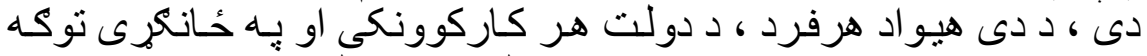

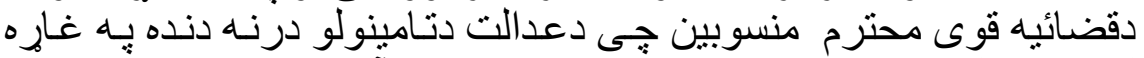

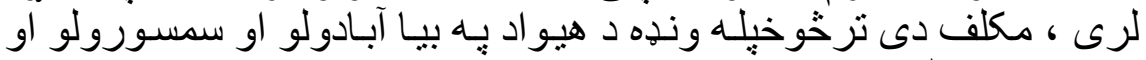

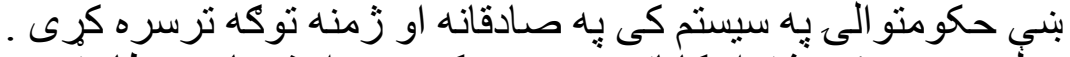

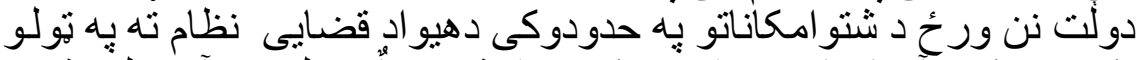

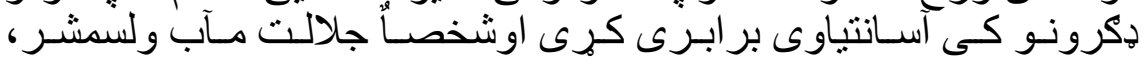




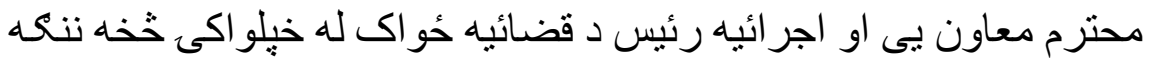

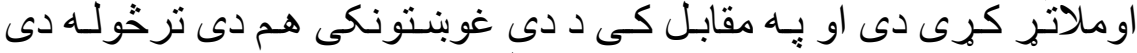

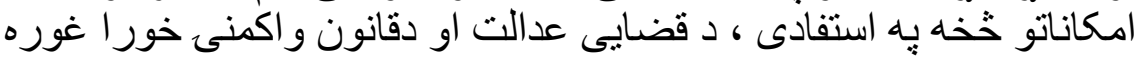

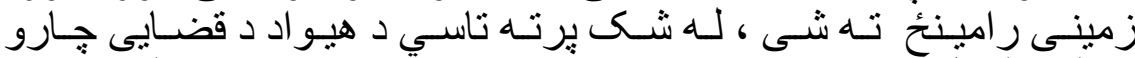

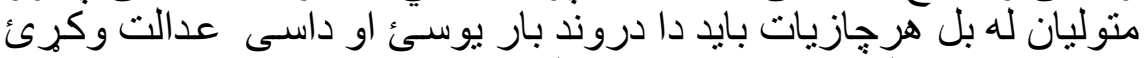

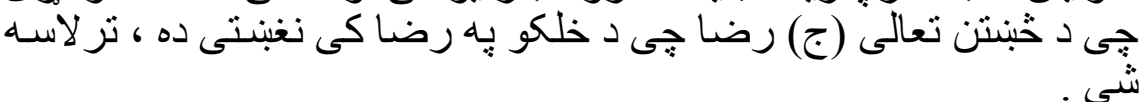

درخاتمه ضمن تشكر و امتنان از حضورجالالتمابان استاد دانش،داكتر

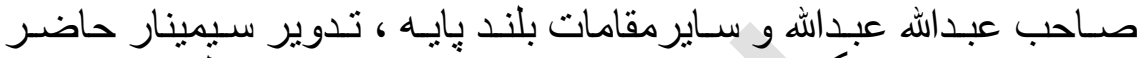

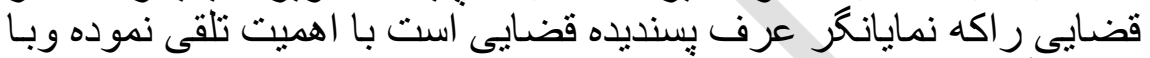

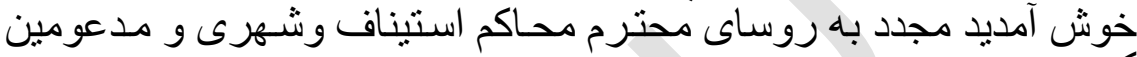

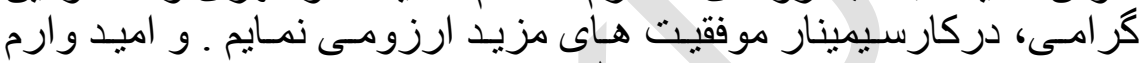

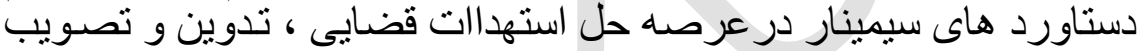

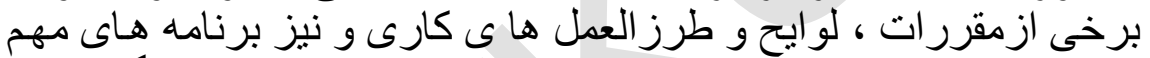

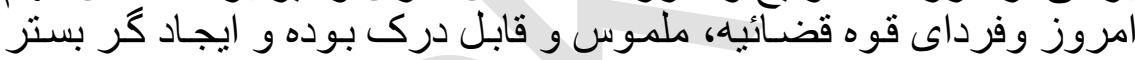

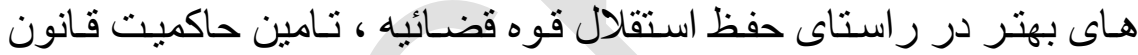

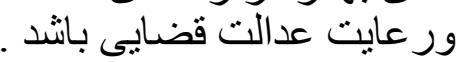

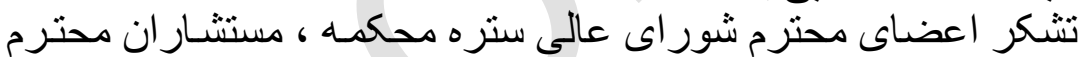

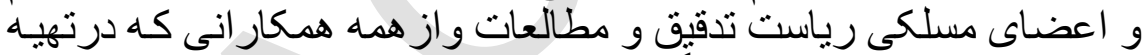

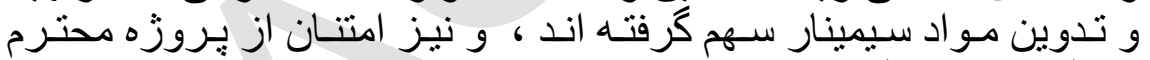

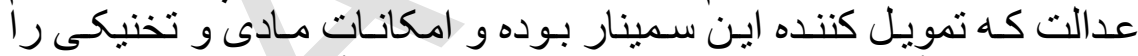

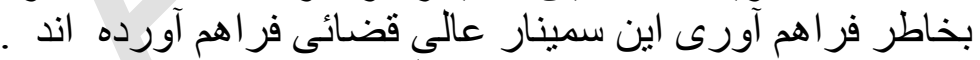

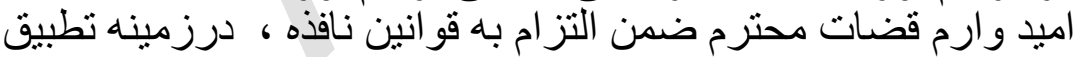

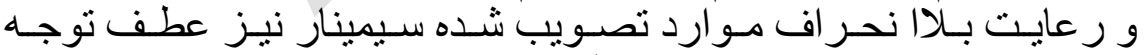

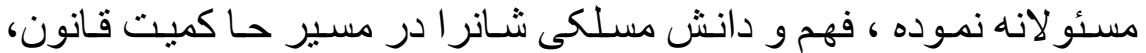

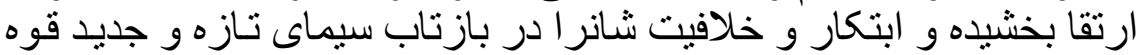

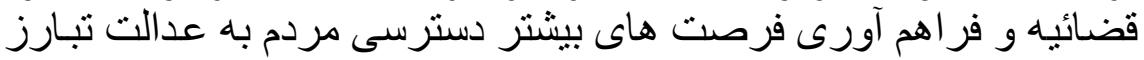
دهند

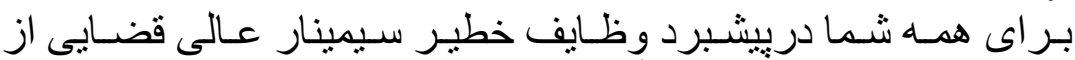

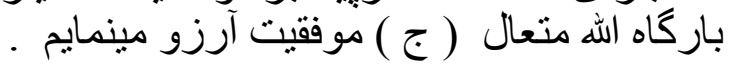


بيانيه رئيس ستره محكمه در مراسم افتتاح سيمينار عالى قضائى

\author{
ومن الله التوفيق \\ السلام عليكم و رحمة الله وبر كاته

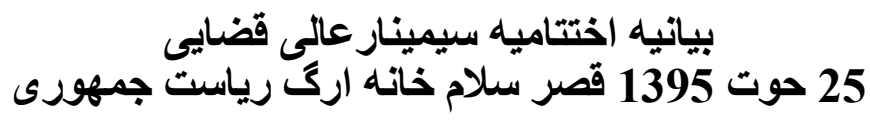

نحمدو ونصلى على رسول الكريميم ، اما بعد

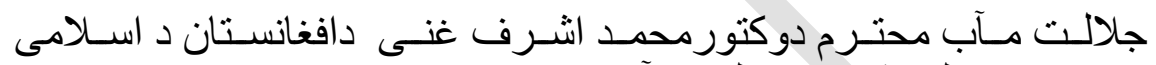

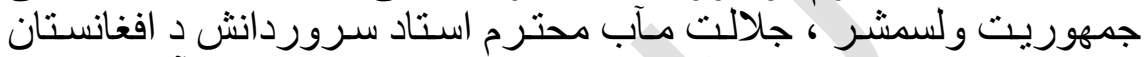

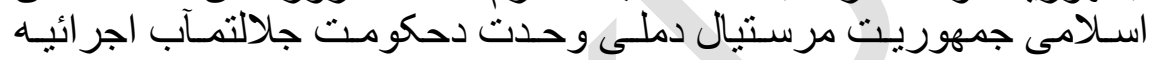

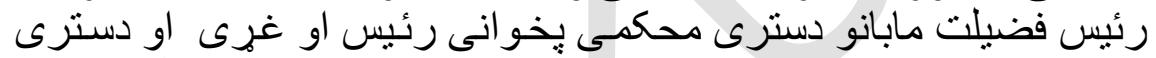

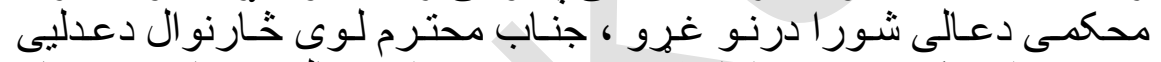

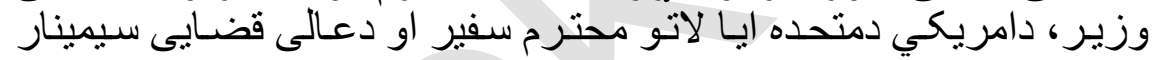

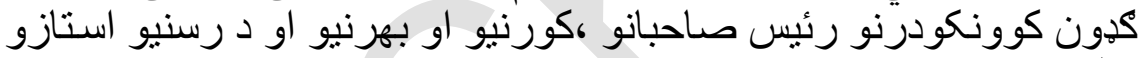

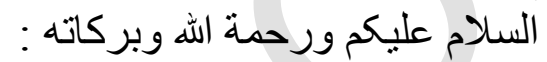

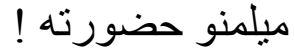

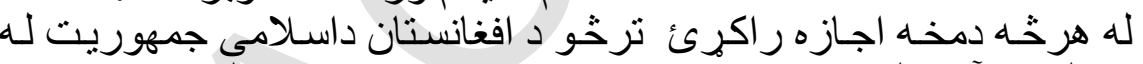

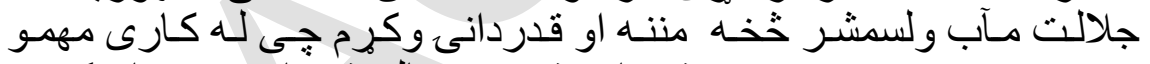

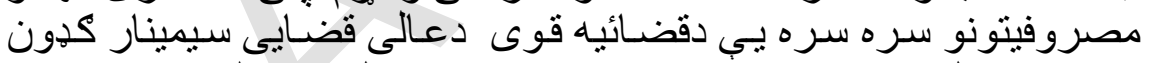

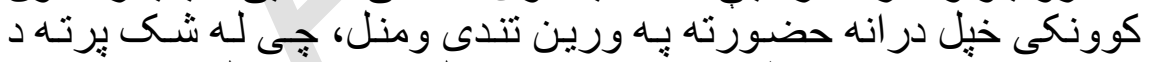

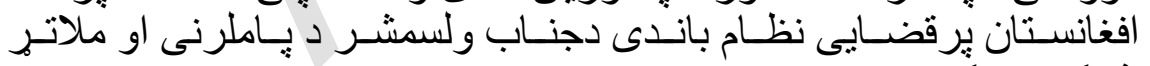

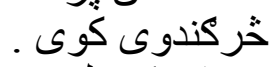

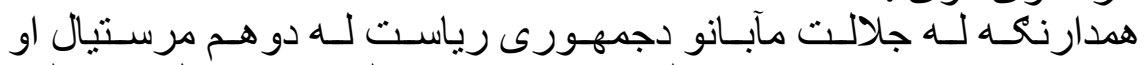

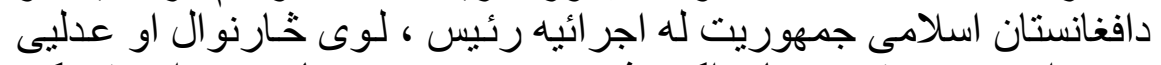

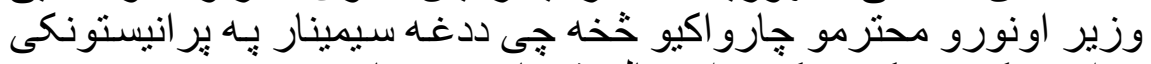

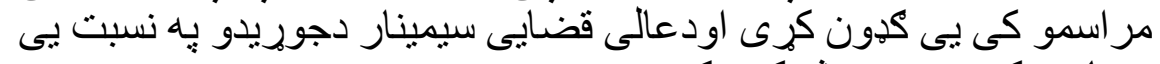

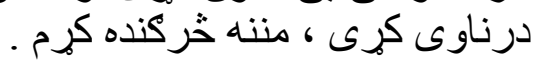


بيانيه رئيس ستره محكمه در مراسم اختتاحيه سيمينار عالى قضائى

قضاء

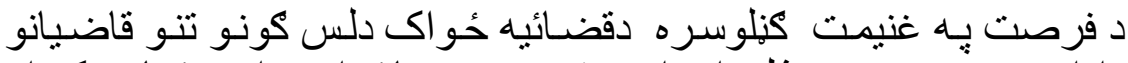

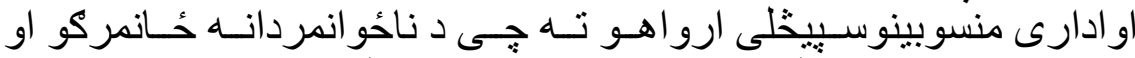

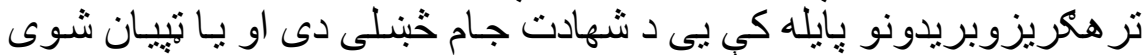

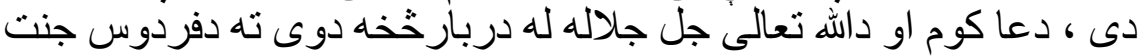

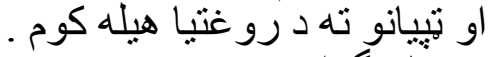

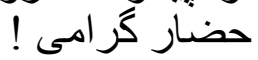

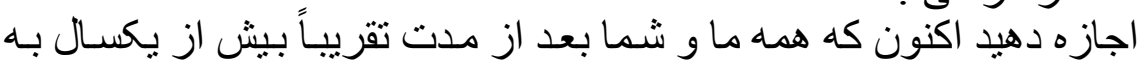

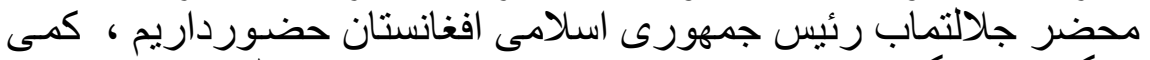

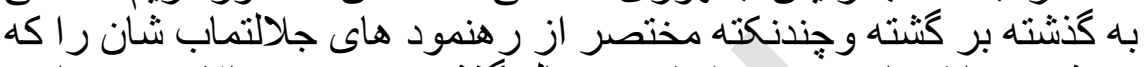

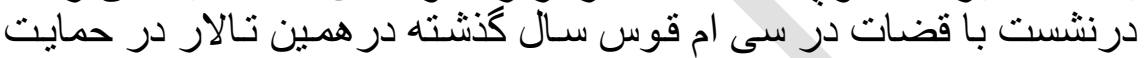

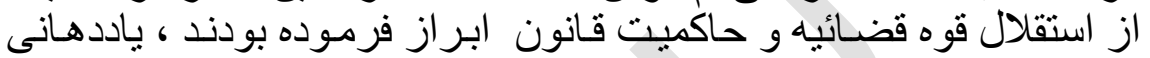

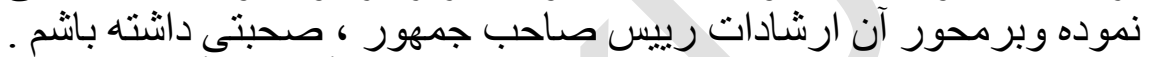

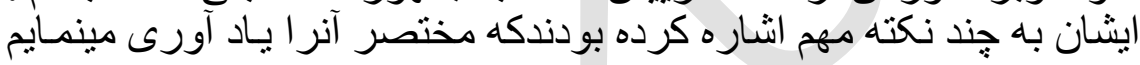

ا ـ هيج كس در فيصله هـاى قضـايى حق مداخله رـ را ندارند ، قاضـى نزد

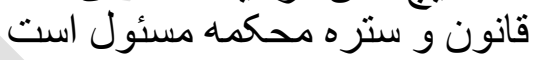
r ـ تطبيق بلا استثناى قانون در سيستم حقوقى و قضـايى افغانستان اصل

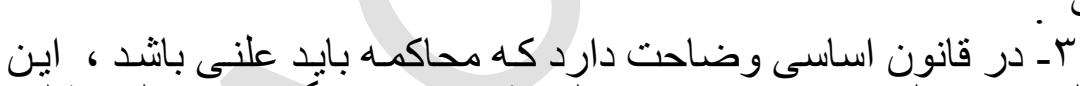

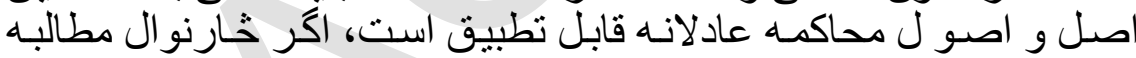

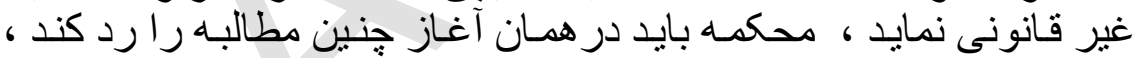

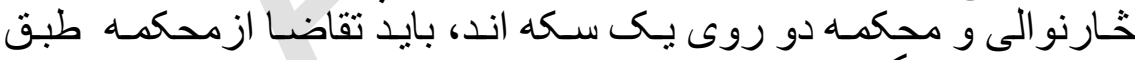

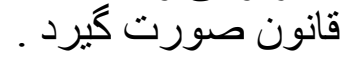

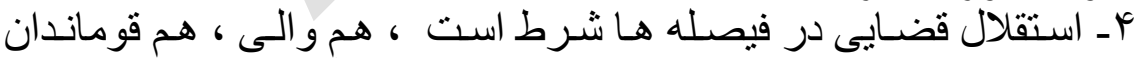

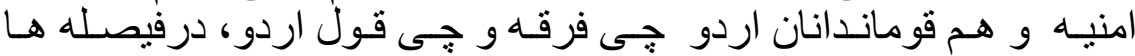

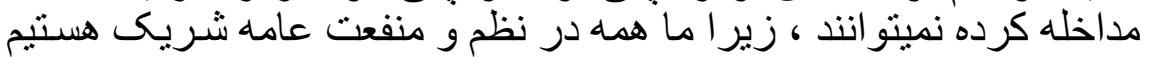

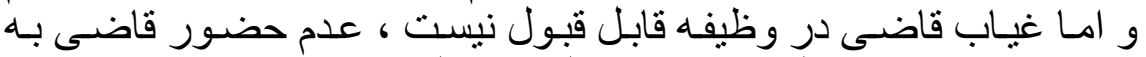

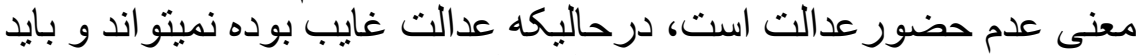

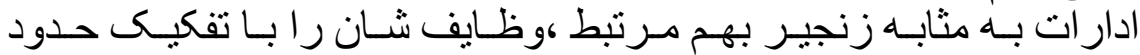

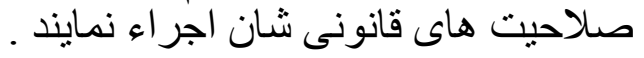




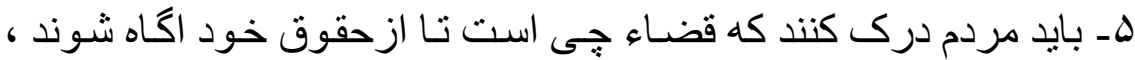

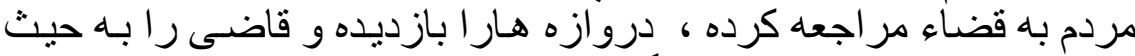

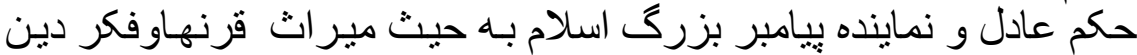

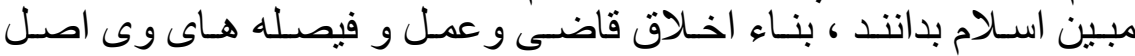
شر عى است است

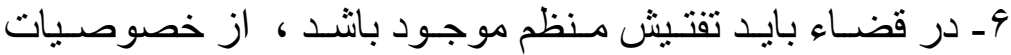

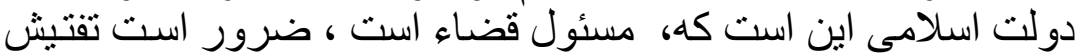

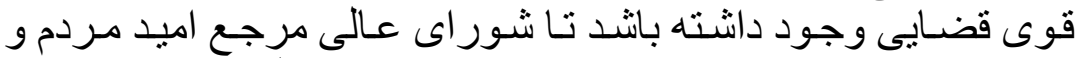

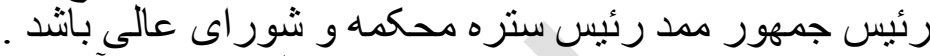

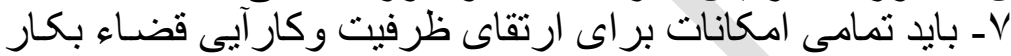
برده شود .

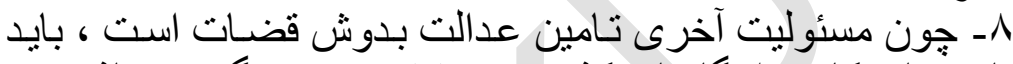

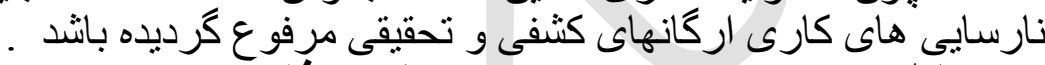

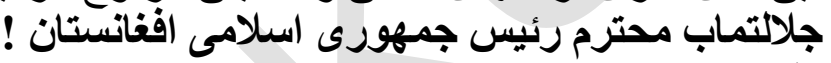

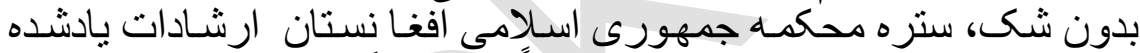

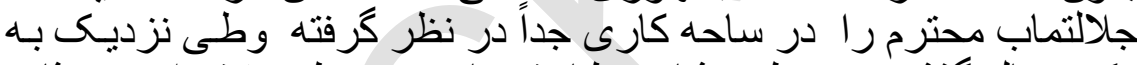

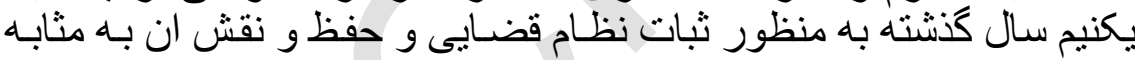

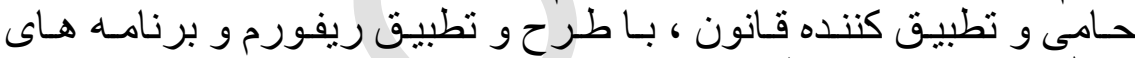

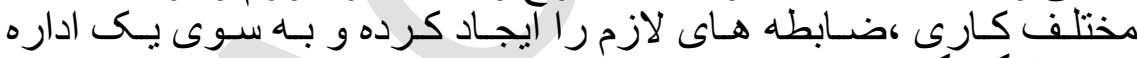

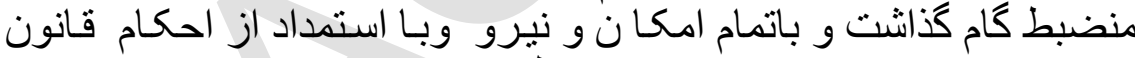

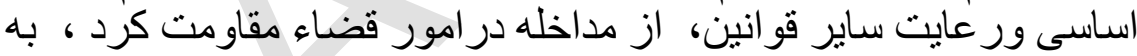

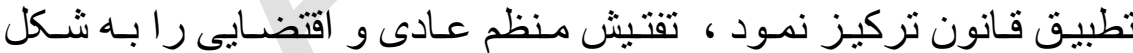

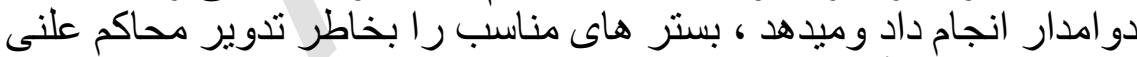

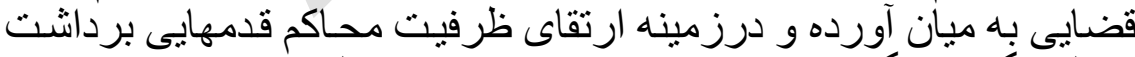

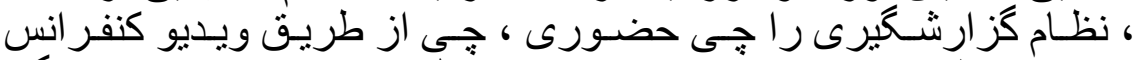

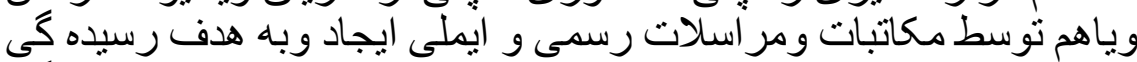

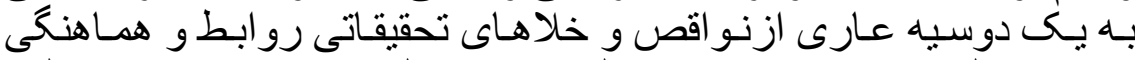

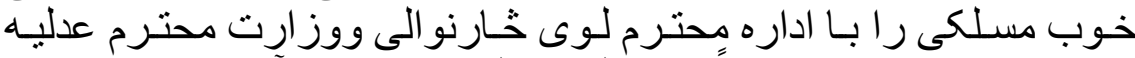

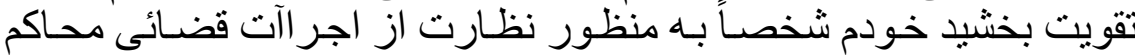

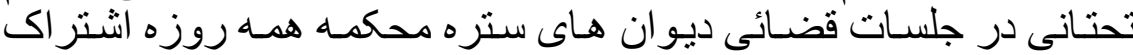




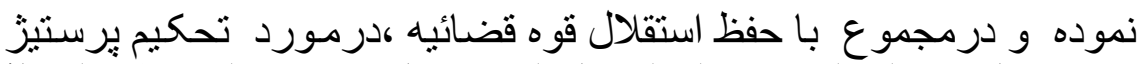

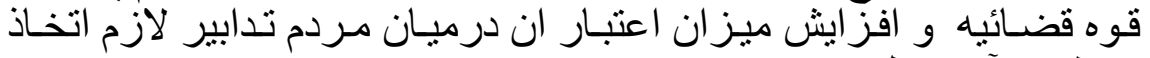

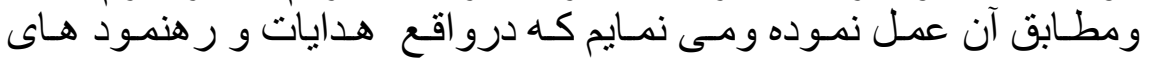

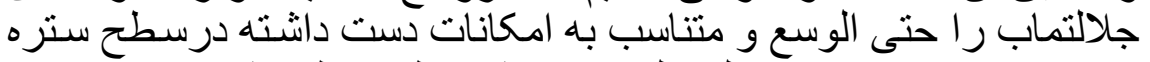

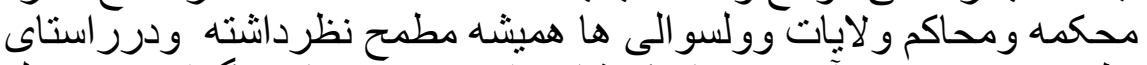

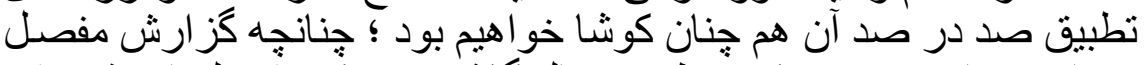

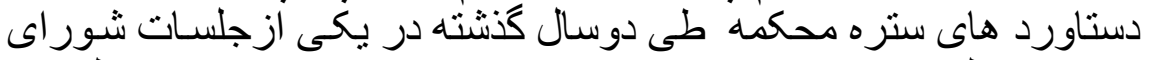

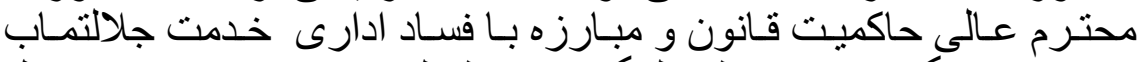

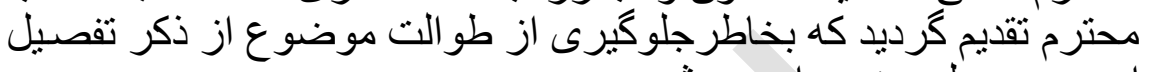

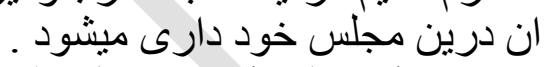

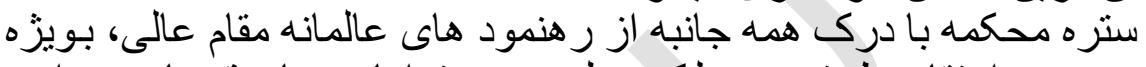

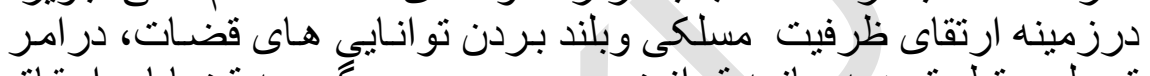

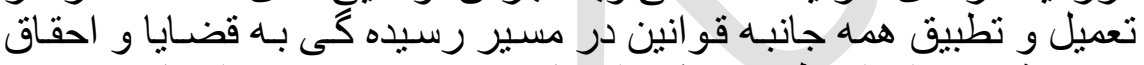

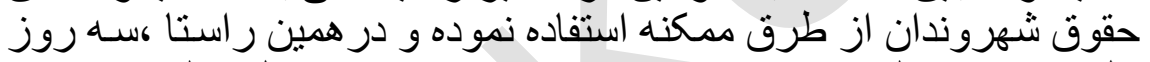

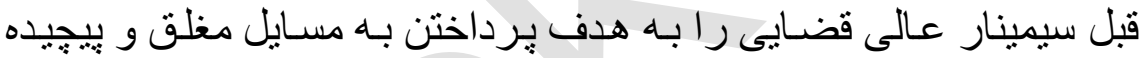

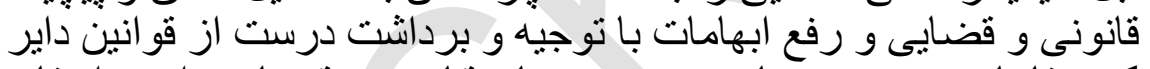

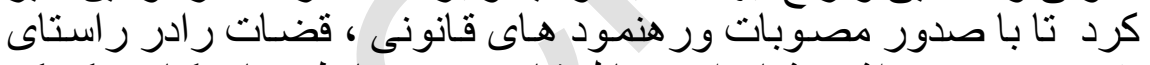

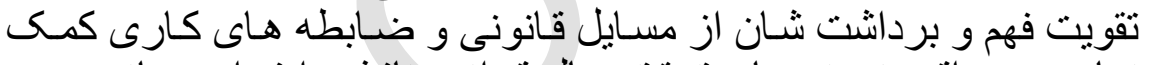

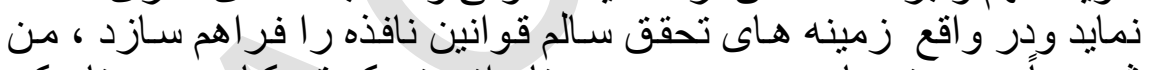

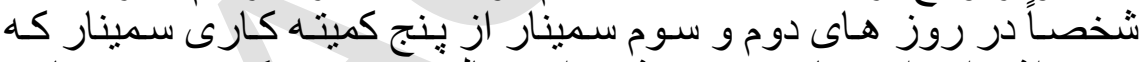

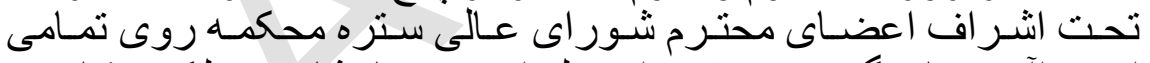

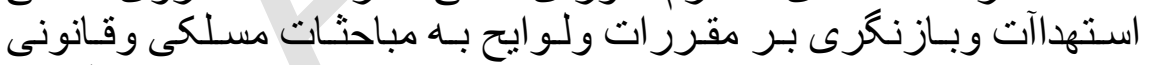

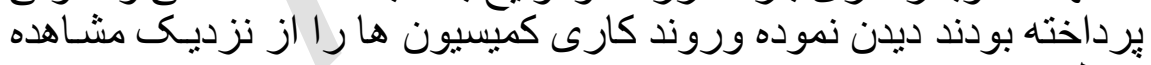

\section{وقابل قدر ارزيابى نمودم.

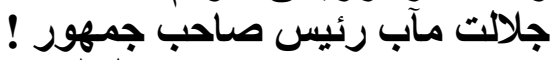

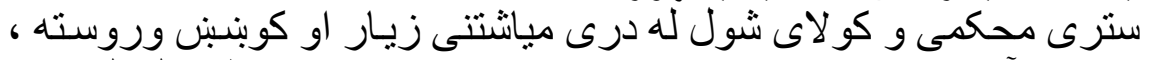

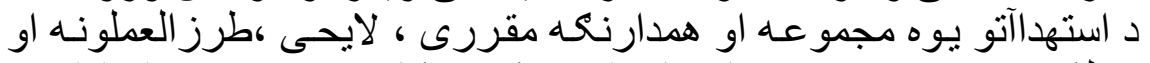

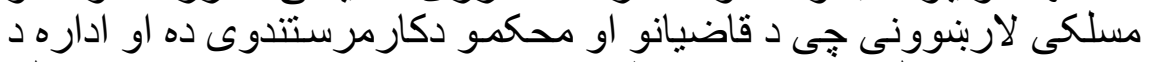

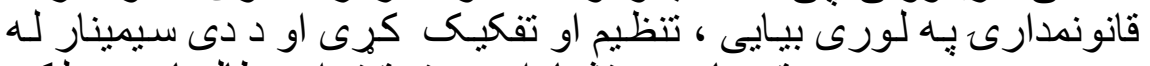

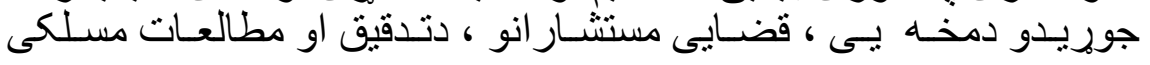


بيانيه رئيس ستره محكمه در مراسم اختتاحيه سيمينار عالى قضائى

قضاء

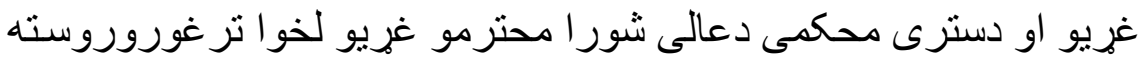

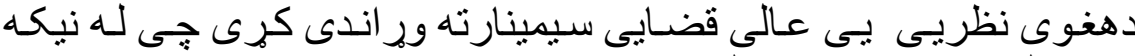

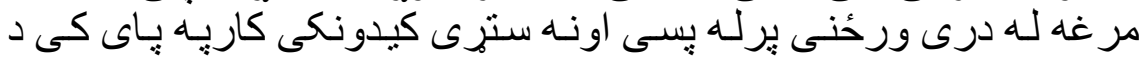

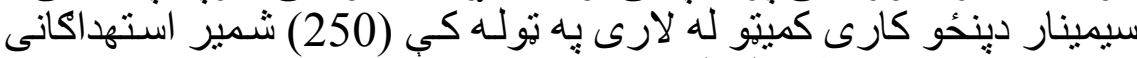

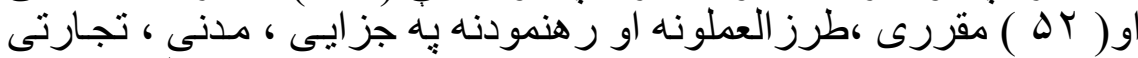

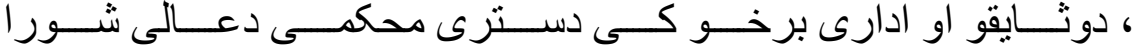

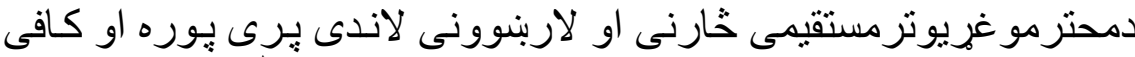

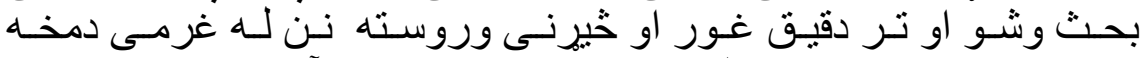

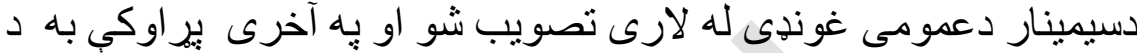

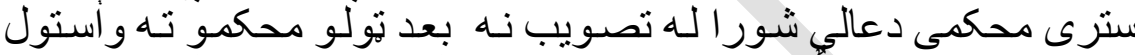

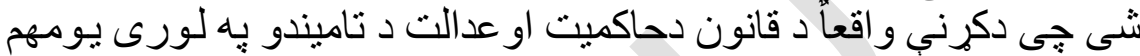

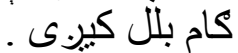

جلالت مآب محترم ولسمشر او درنوحاضرينو !

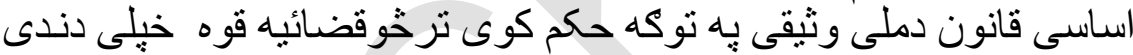

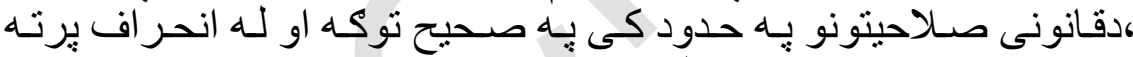

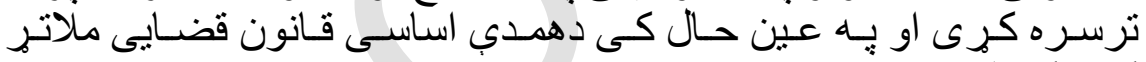
كوونكى اوسنى .

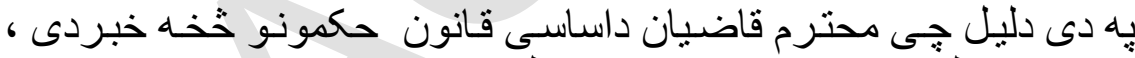

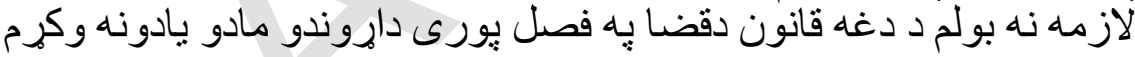

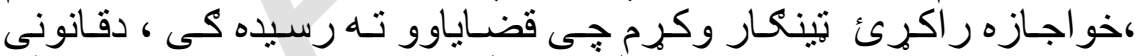

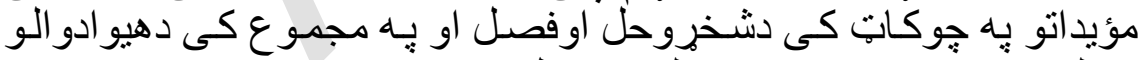

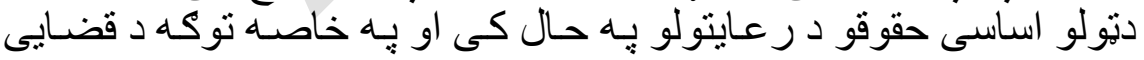

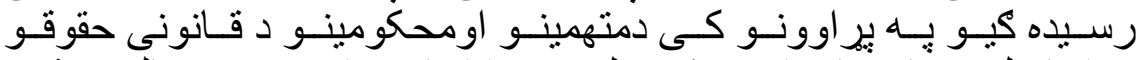

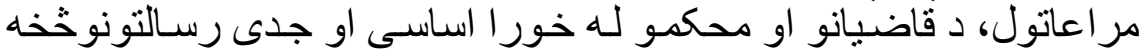

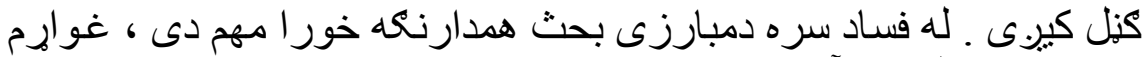

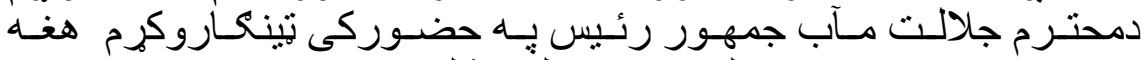

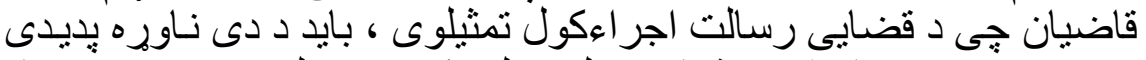

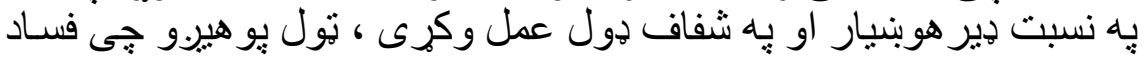




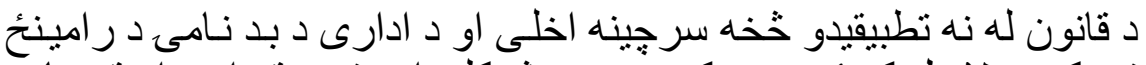

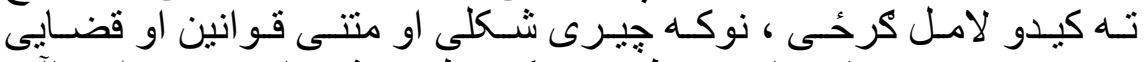

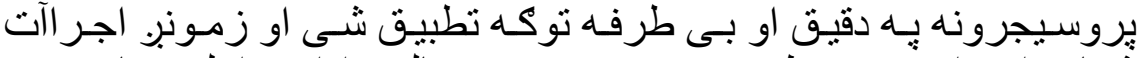

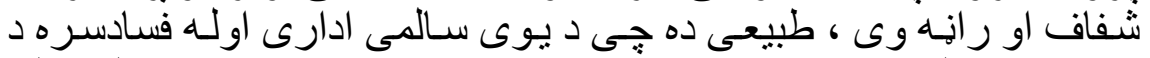

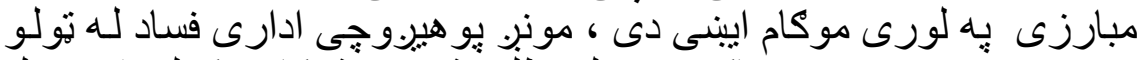

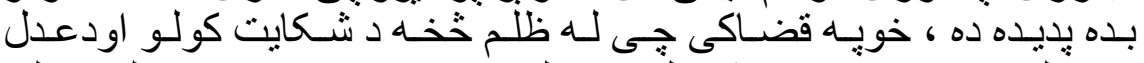

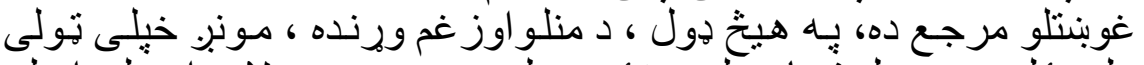

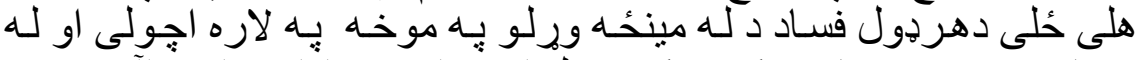

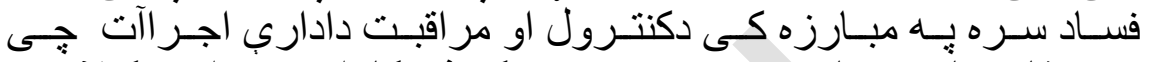

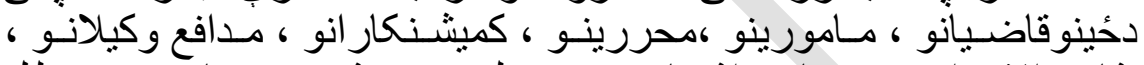

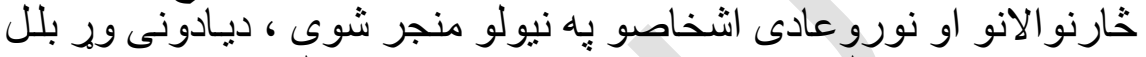

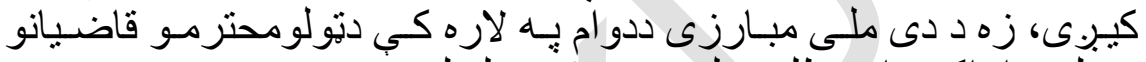

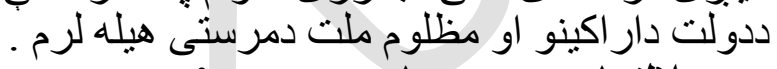

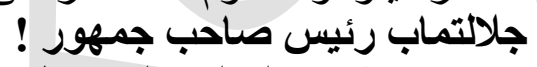

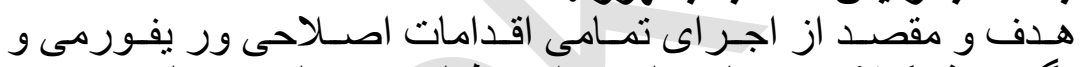

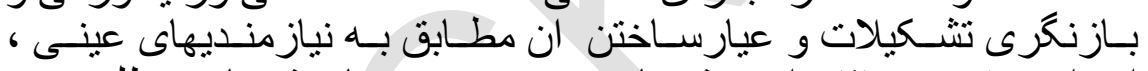

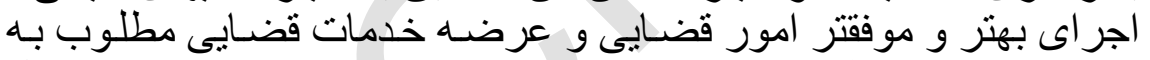

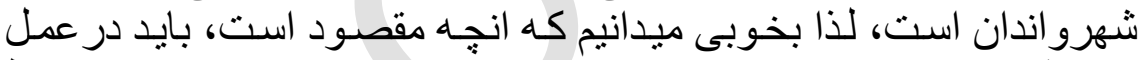

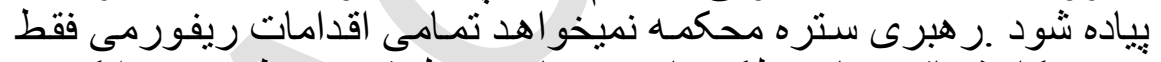

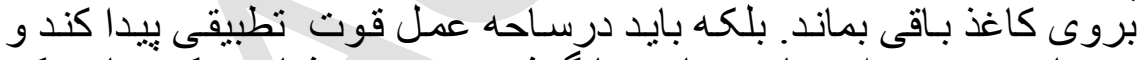

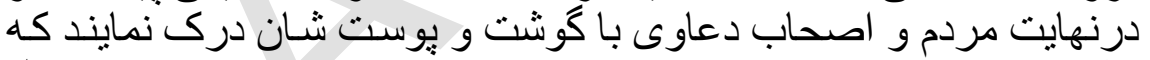

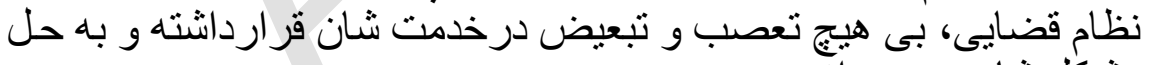

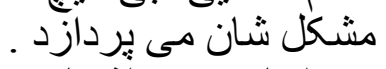

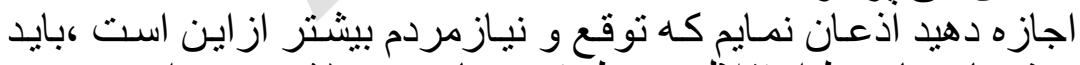

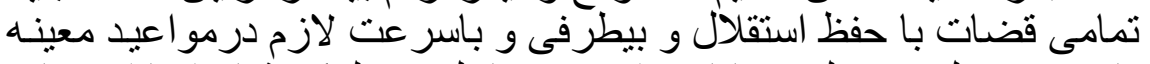

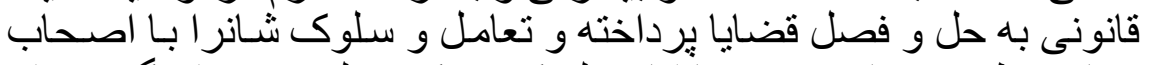

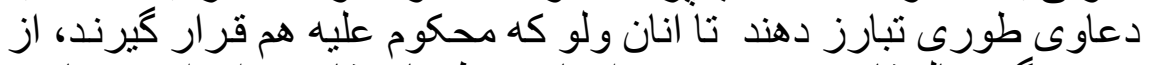

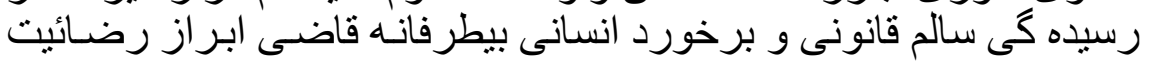

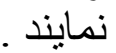


بيانيه رئيس ستره محكمه در مراسم اختتاحيه سيمينار عالى قضائى

قضاء

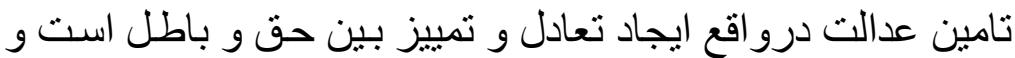

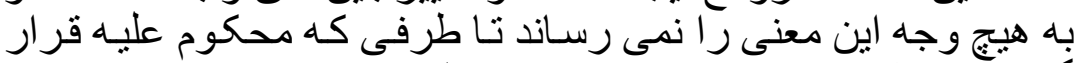

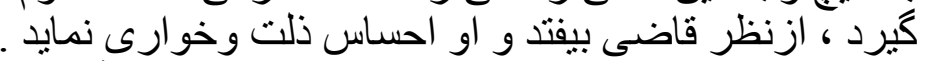

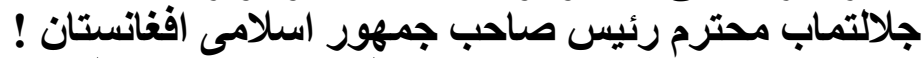

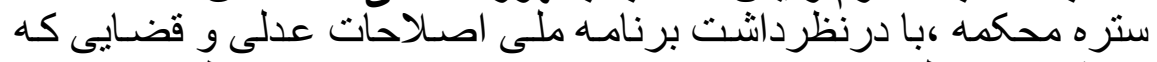

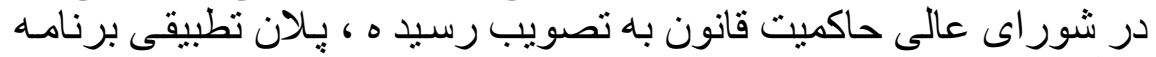

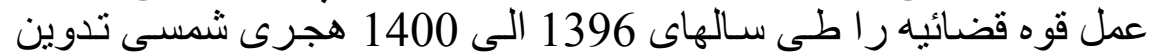

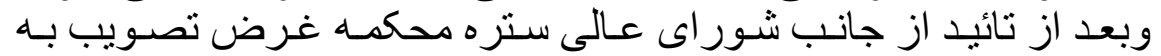

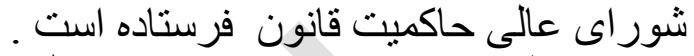

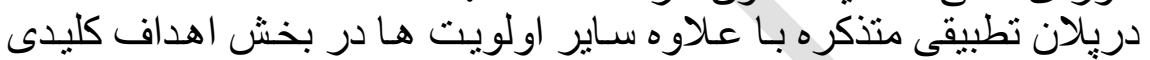

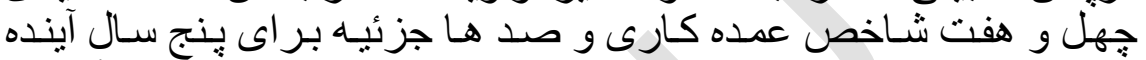

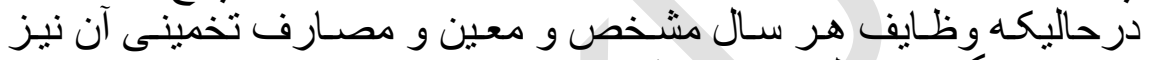

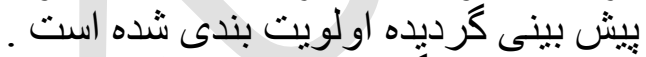

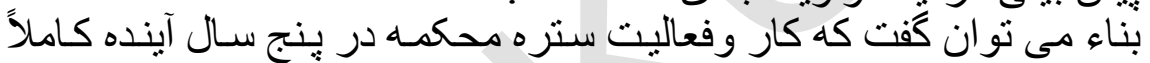

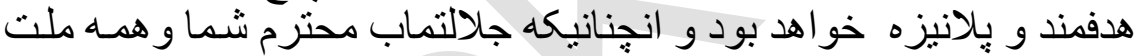

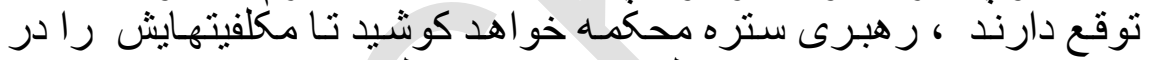

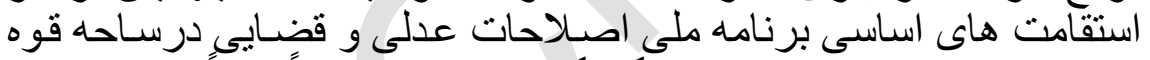

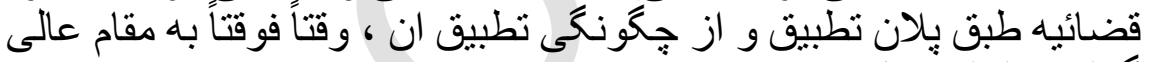

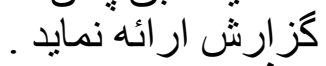
د افغانستان د اسلامى جمهوريت جلاندانت مآب ولسمشر ؛

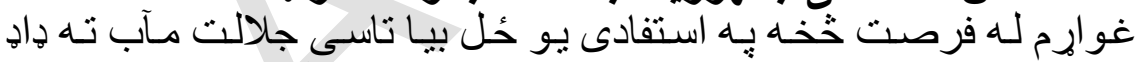

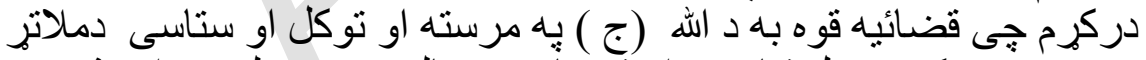

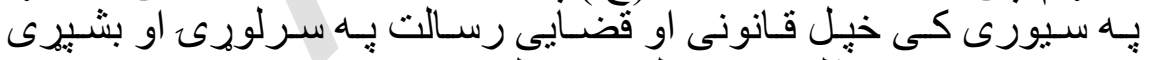

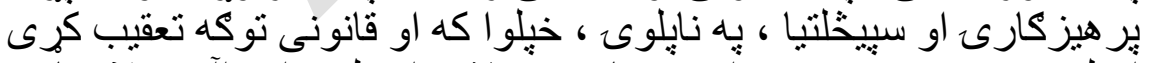

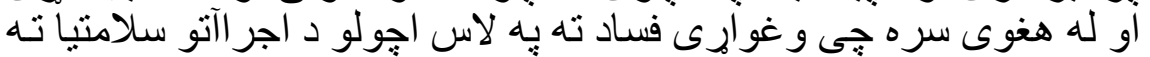

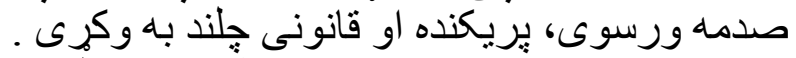

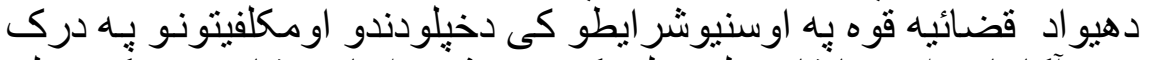

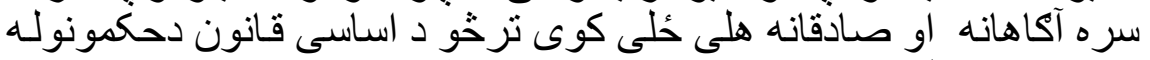

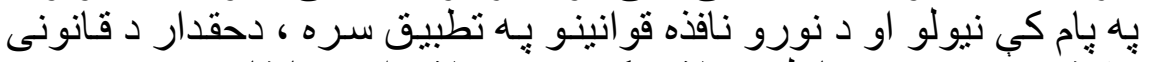

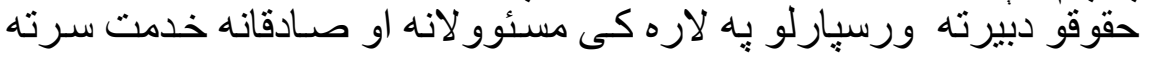




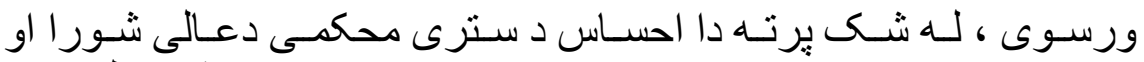

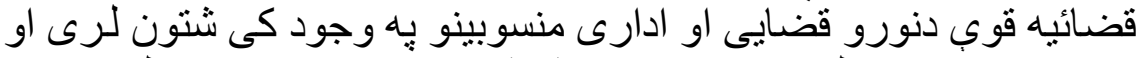

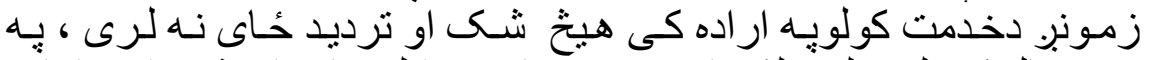

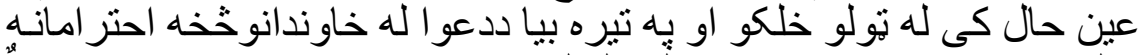

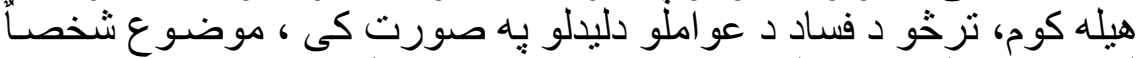

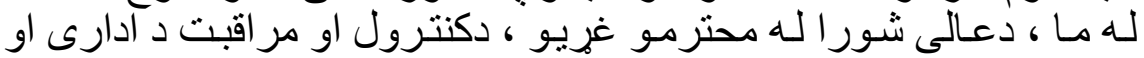

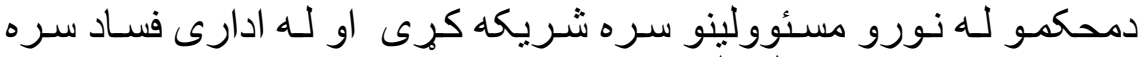

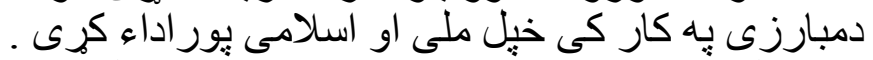

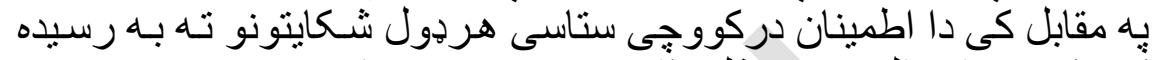

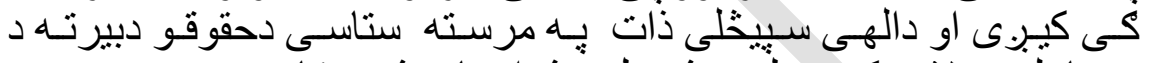

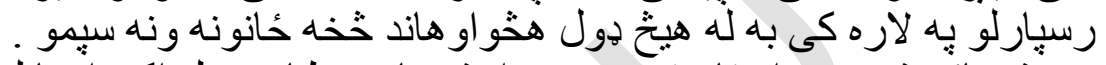

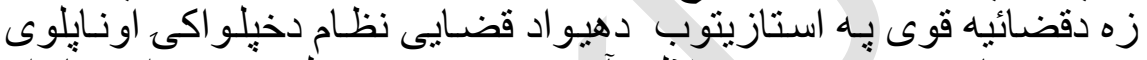

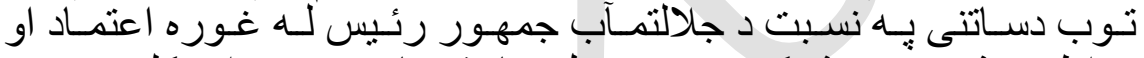

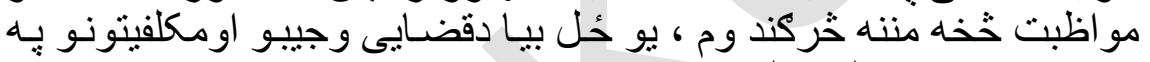

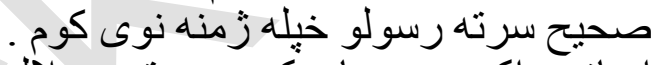

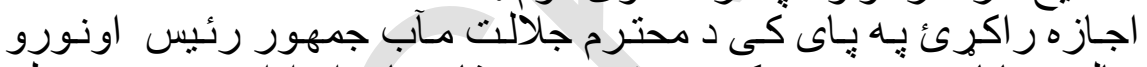

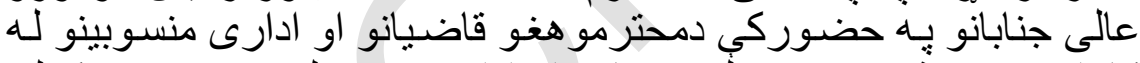

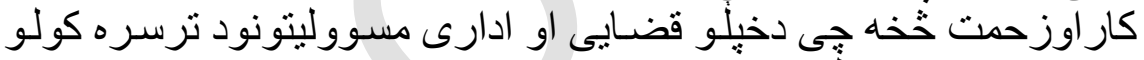

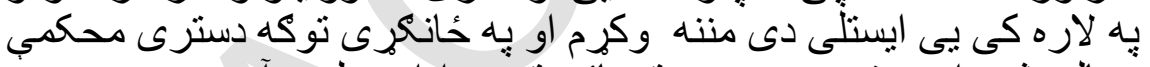

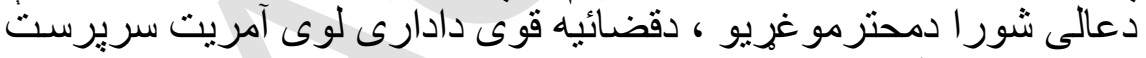

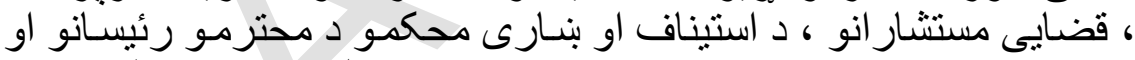

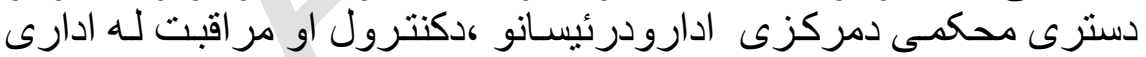

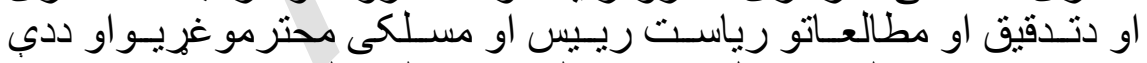

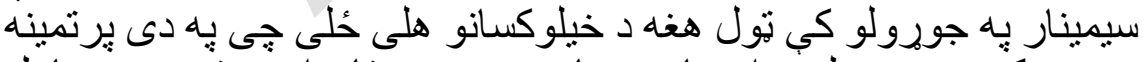

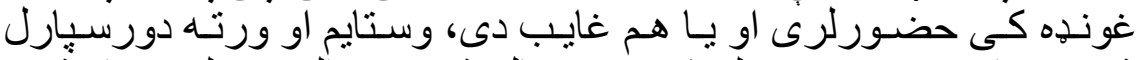

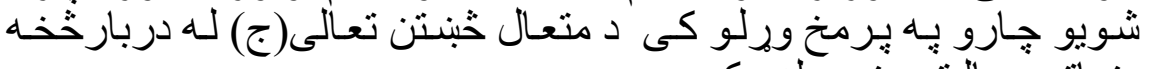

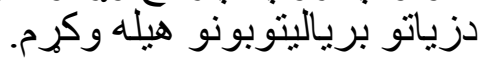

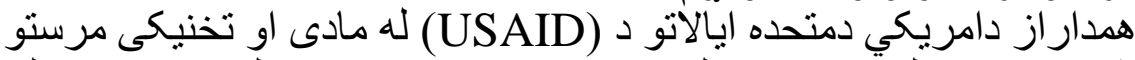

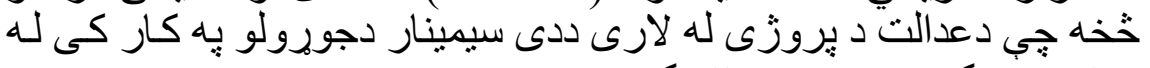

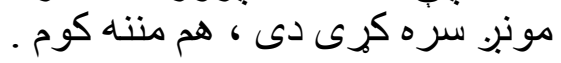


بيانيه رئيس ستره محكمه در مراسم اختتاحيه سيمينار عالى قضائى

\section{قضناءو}

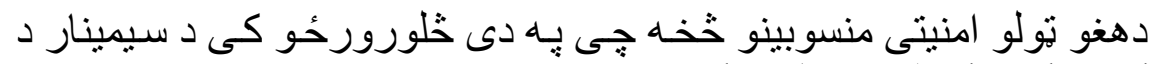

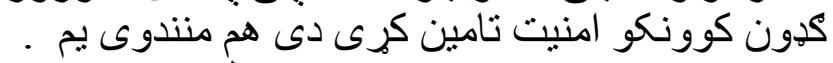

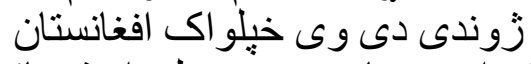

تاند او هوسادى دوى دوى دعدلى او قضائى افئى

الســلام علـيكم ورحمـــة الله

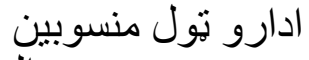
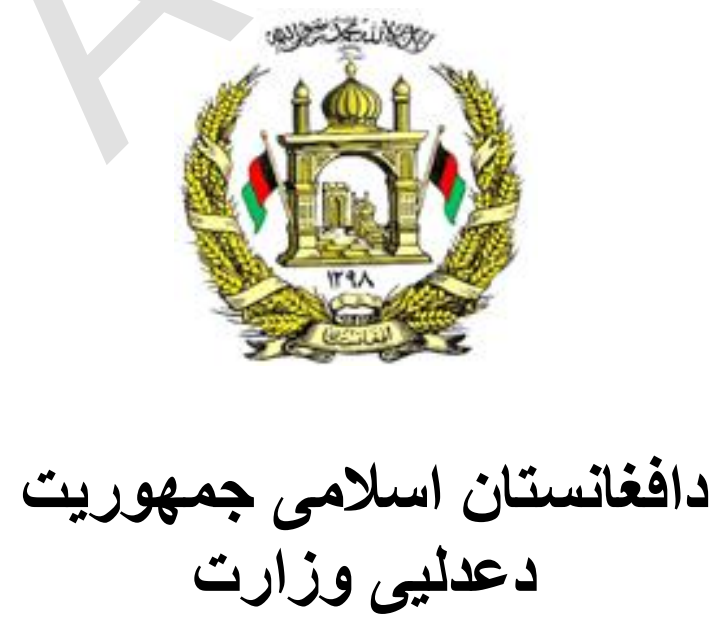

رسمى جريده 
ضمايم شماره (†) و (ه) قانون جزاء

قُخاءو

ضميمه شماره (4) قاتون جزاء ضميمه شماره (5) قانون جزاء (4) جانون

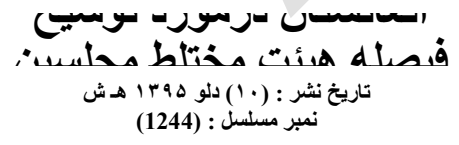

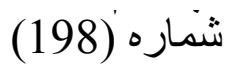

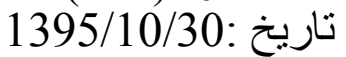

ماده اول: - ماري
دجزاء دقانون (4) كنجه ضميمه

دجزاء دقانون (5) كنجه ضميمه (4) فئه

-

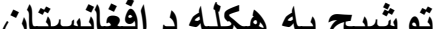

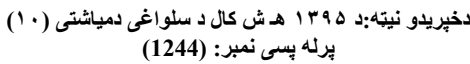

ك-رن

كنه : (198)

نيته :1395/10/30 : نئه

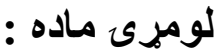

د افغانستان د اساسى قـانون د (64) به تاسهى از احكام جزء(16) ماده 


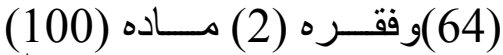
قـانون اساسـى افغانسـتان فيصـله

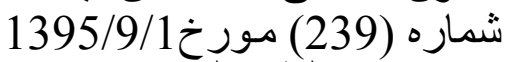

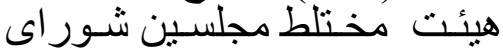

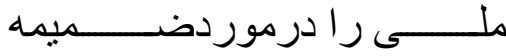

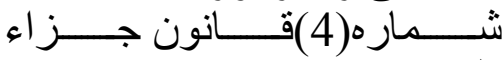
طى(13)ماده، توشيح مى مى دارم .

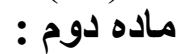
اين فرمان ازتاريخ نوشيح نافذ،

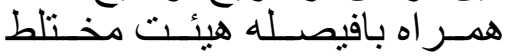

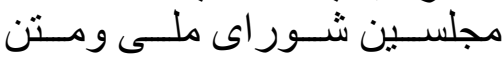

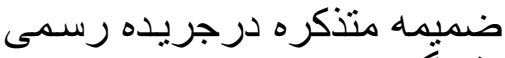

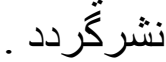

محمد اشرف غني إنماني رئيس جمهورى اسلامى فئن افغانستان

ضميمه شماره (4) قانون جزاء

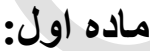

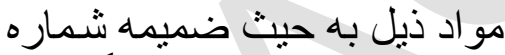

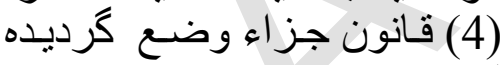

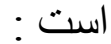

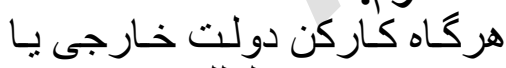

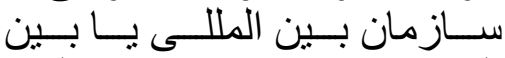

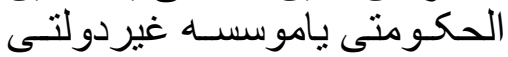

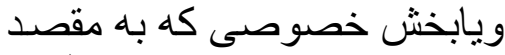

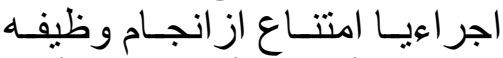

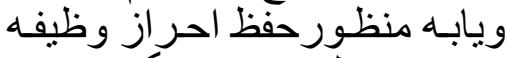

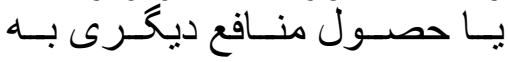

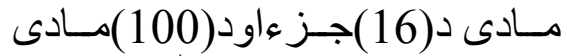

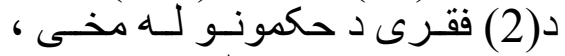

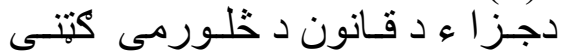

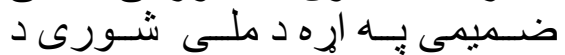

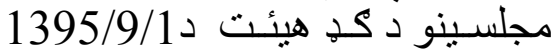

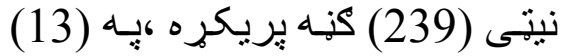
مادو كى نوشيح كوم. دوه يمهل ماده : دون

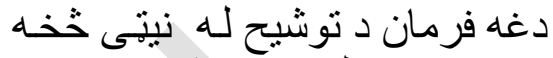

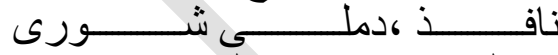

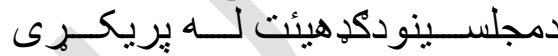

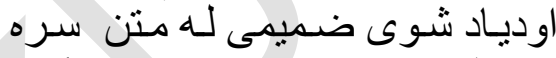

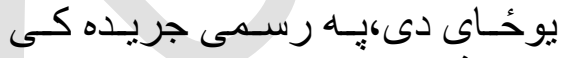

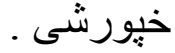
د افغانستان اسلامى جمهي الفرويت رئيس

\section{د جزاء د قاتون (4) كنه ضميمه} لوميرى ماده : لون دانون

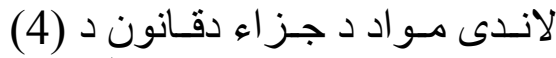

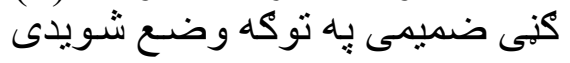
دوه يمه ماده :

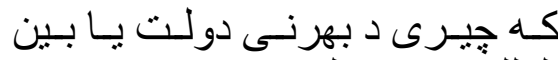

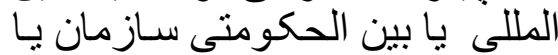

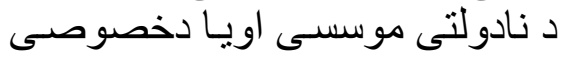

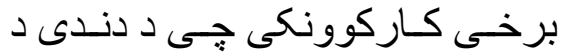

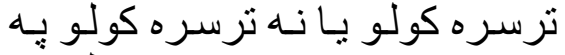

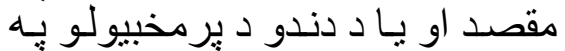

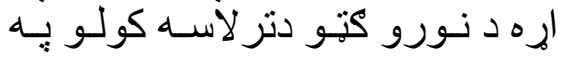


ارتباط يِيشبرد وظيفه بـ اسم خود

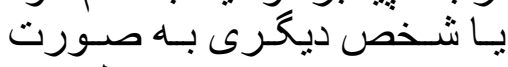

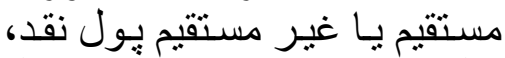

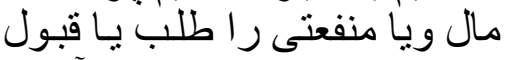

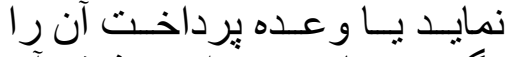

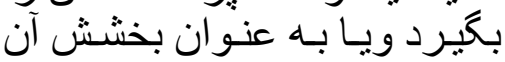

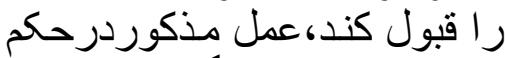

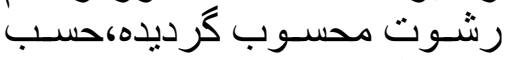

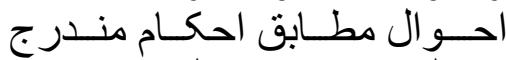

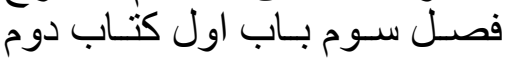
اين قانون مجاز ات ميشود.

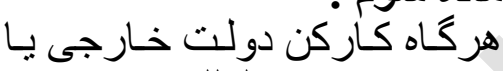

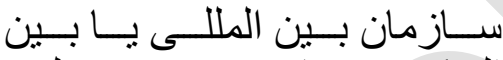

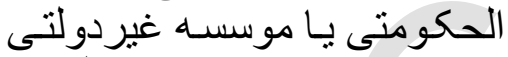

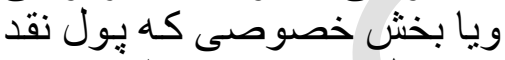

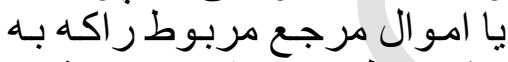

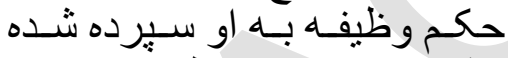
باثد بر اي خود بـه طور مستقيم يا

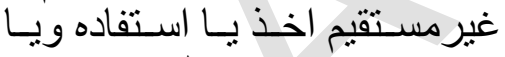

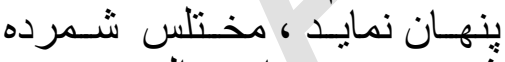

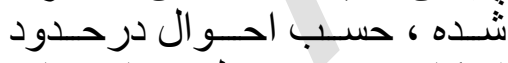

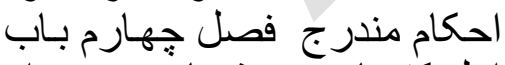

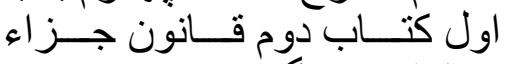

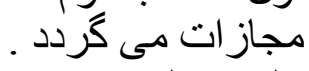

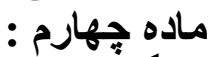

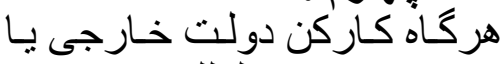

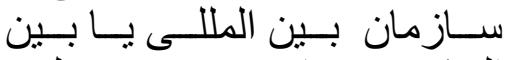

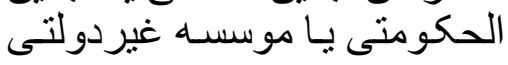

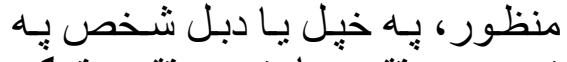

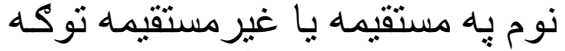

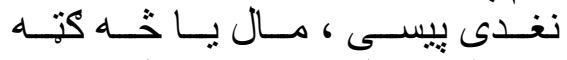

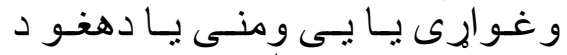

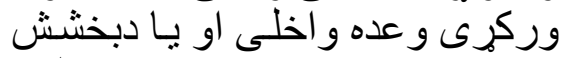

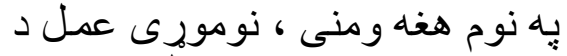

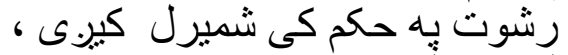

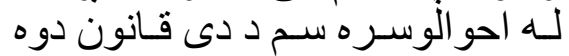

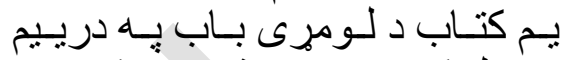

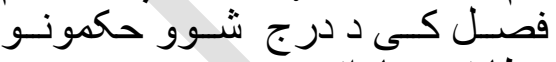
مطابق مجاز اتير.ى د. د.

\section{درييمه ماده :}

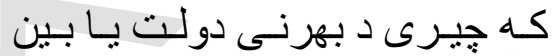
المللى يا بين الحكومتى سازمان دونى يانيا

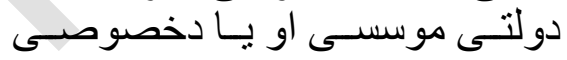

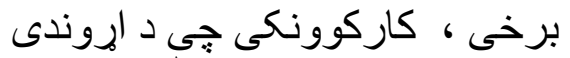

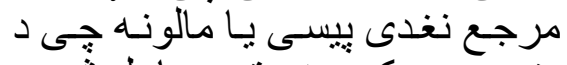

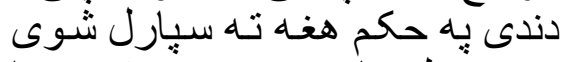

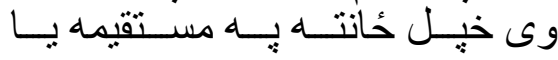

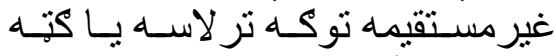

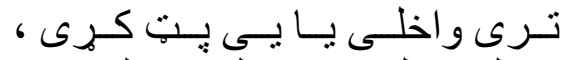

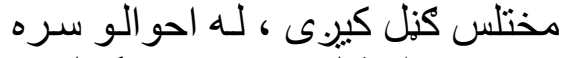

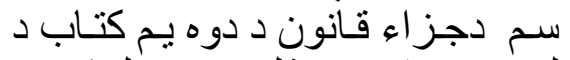

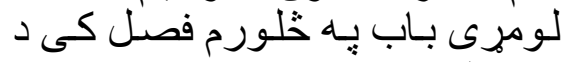

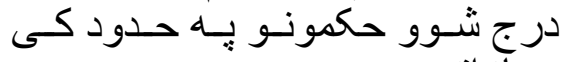

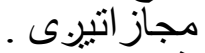

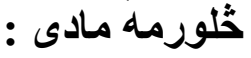

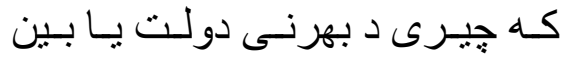


و يا بخش خصوصسى كه دريك

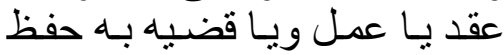

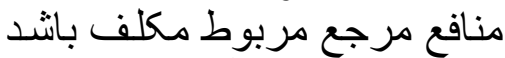

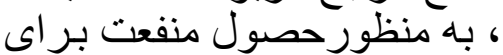

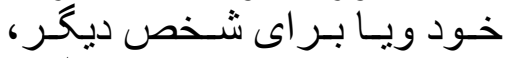

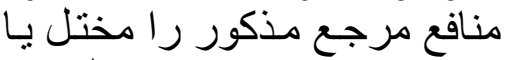
متضرر سازد، حسب احور مدر ال تابع

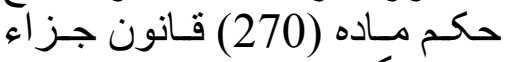
قر ارميكيرد . ماده ينجم : مريز هركاه جر ائم مندر ج مو اد سوم و

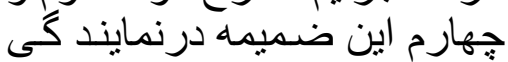

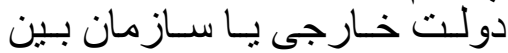

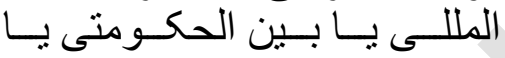

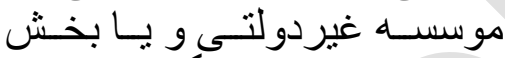

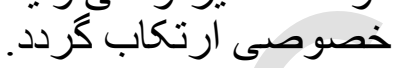
تحريك دعوى جز ايهى وتعقيب

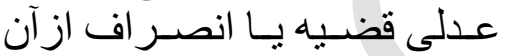

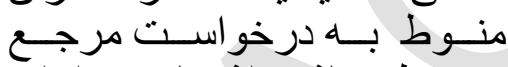

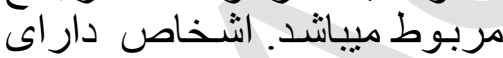

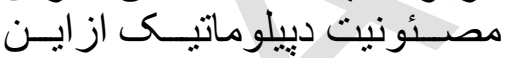
حكم مستثنى مهى بادثد.

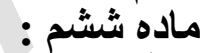

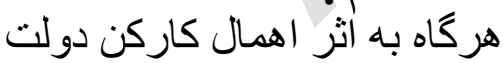

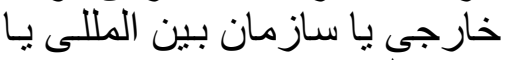

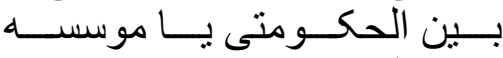

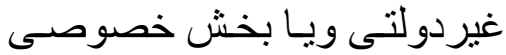

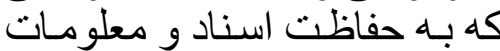

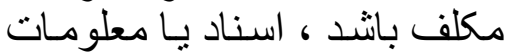

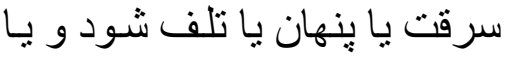

المللى يا بين الحكومنى سازمان بان إنا

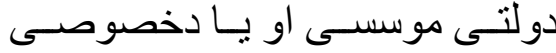

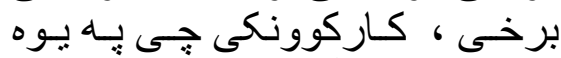

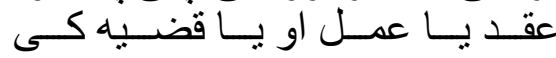

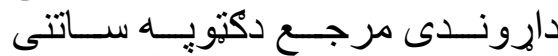

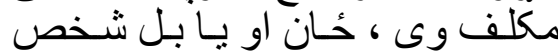

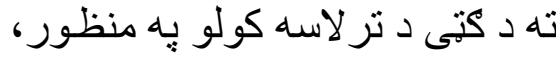

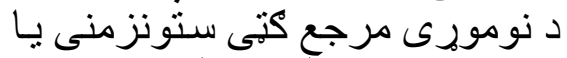

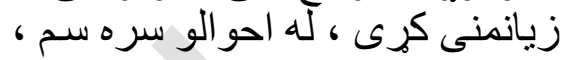

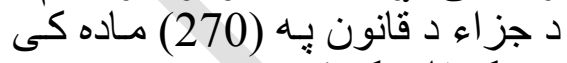
د دكم تابع كرحُّى.

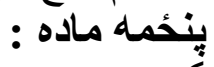

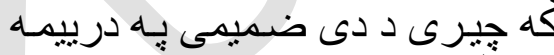

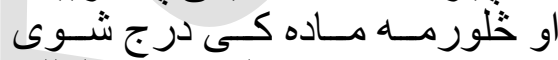

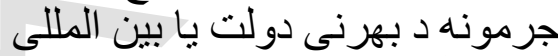

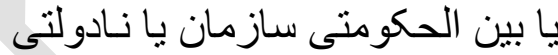

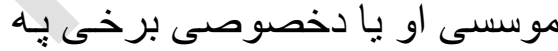

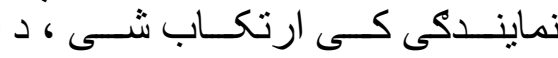

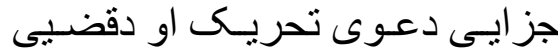

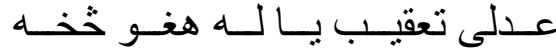

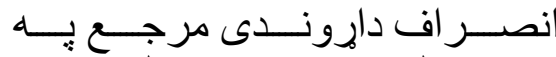

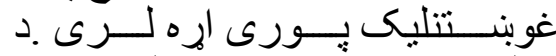

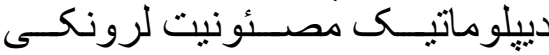
اشخاص لدى حكم خخه مستنتى دى لرى

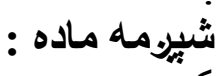

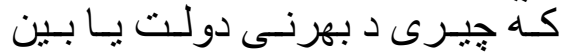

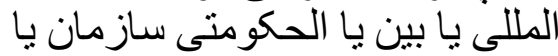

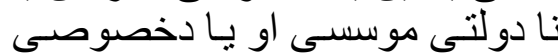

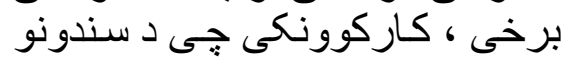




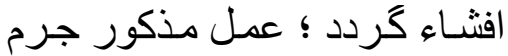

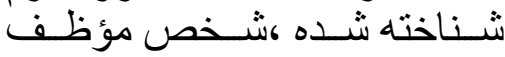

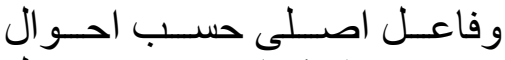

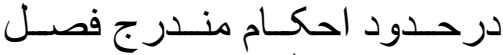

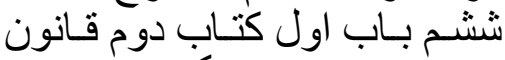
جز اء مجاز ات مى كرّد

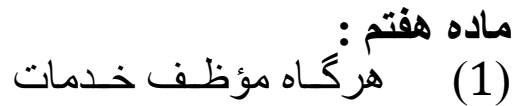

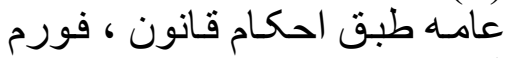

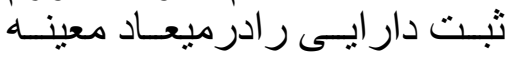

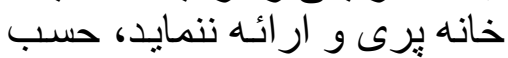
احوال به جزائ نقدى ارئه كـه ازينج

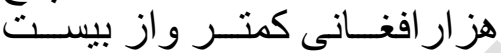

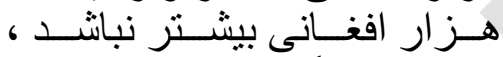

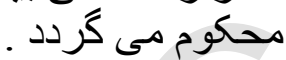
(2) درصورتى كه فورم مذكور

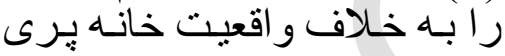

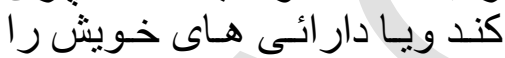

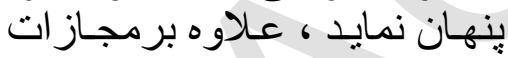

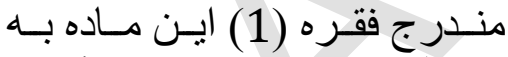

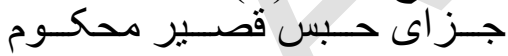
مبشود .

ماده هثتثم :

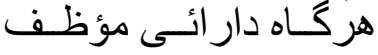

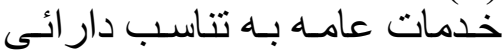

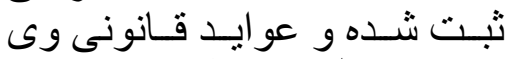

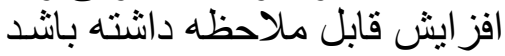

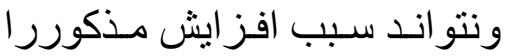

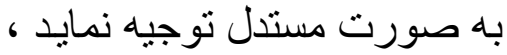
علاوه برمصادره دار ائى حاصله نهله

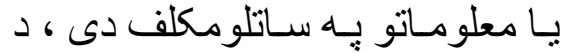

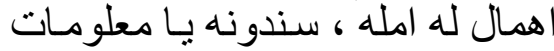

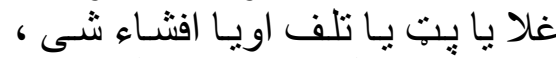

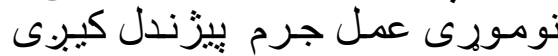

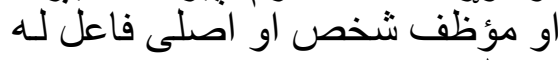

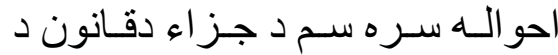

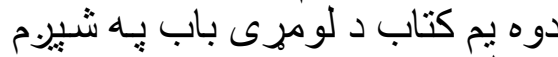

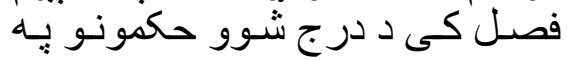

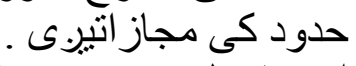
اوومه ماده :

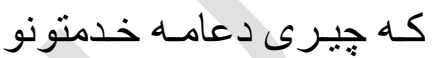

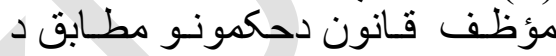

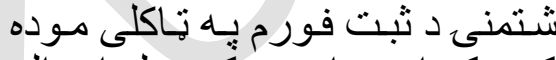

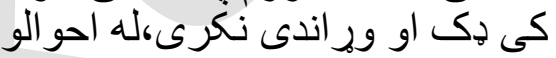

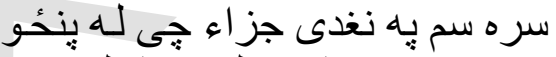

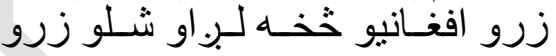

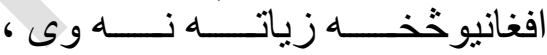
محكو ميزى . فيانيز

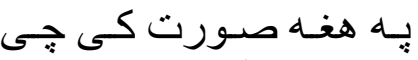

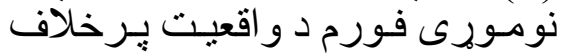

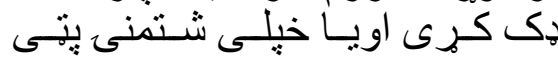

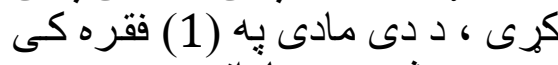

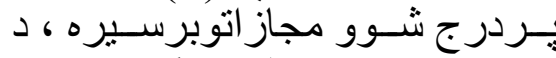

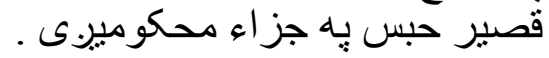
اتمهل ماده : (1)

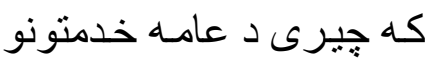

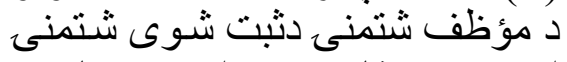

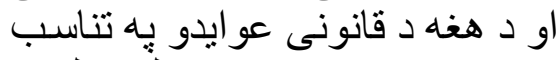

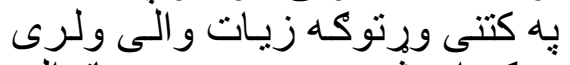

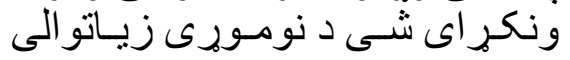




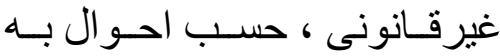

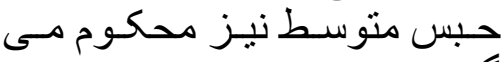
كر دد .

درصسورت عدم امكسان دستياب

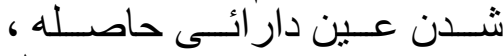

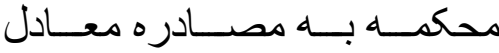

دار ائى مكتسبه حكم مهى نمايد .

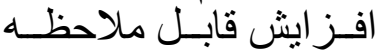
عبارت از افز ايش دار ائسى بيشتر

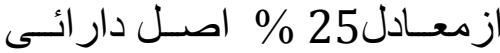
شخص شناخته ميثود داد. ماده نهر :

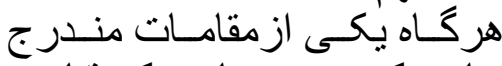

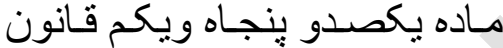
اساسىى افغانستان معامله انتفاعى دادي

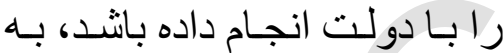

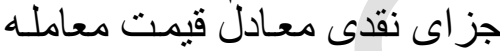

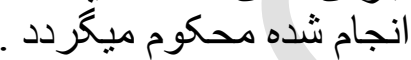

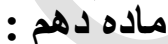

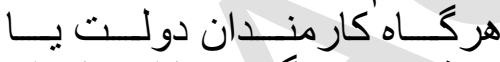
هرشـخص ديخرى بــا اسـتفاده از

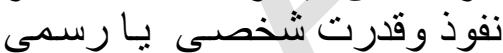

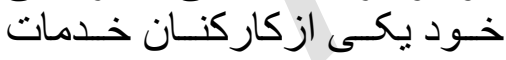

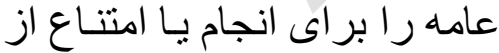

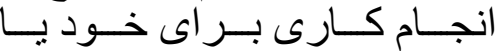
غيروادار سـازد و بـا شـخص بـ بـانـا

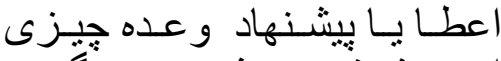

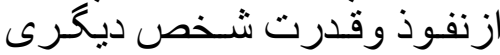

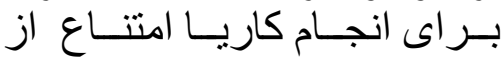
انجام كارى استفاده نمايد ، حسب انب

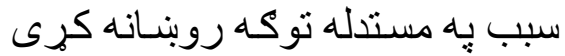

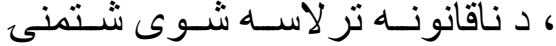

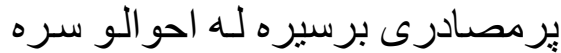

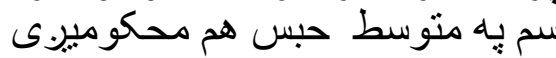

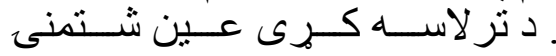

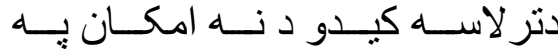

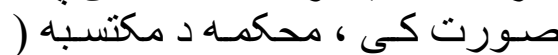

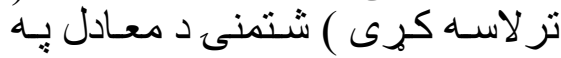
مصادرى حكم كوى.

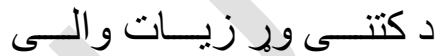

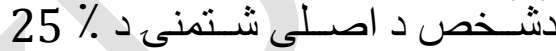

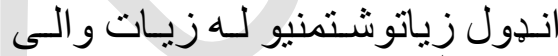

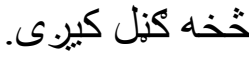

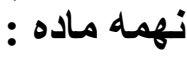

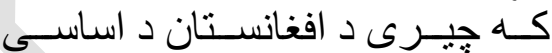

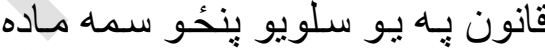

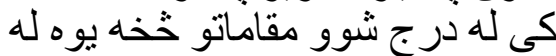

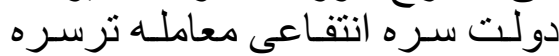

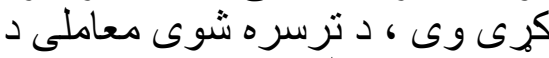

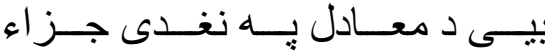

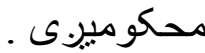

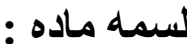
كه جيرى د دولت كارمندان يا هربل

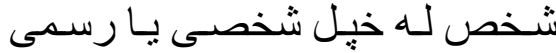

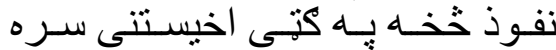

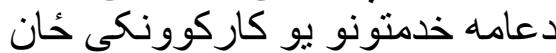

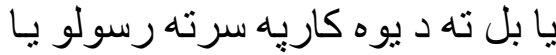

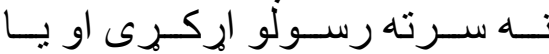

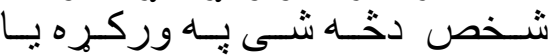


احـــو ال درحـدود احكـــام فصــل

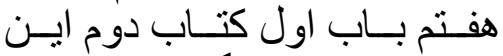
قانون مجاز ات ميكردد . ماده يازدهم : ماندان

شخصى كه اطلاع ده دهنده

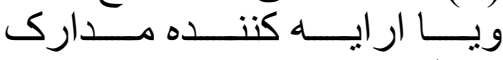
ومعلومات جر ايم فسـاد ادارى ردا

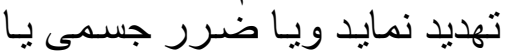

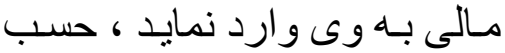

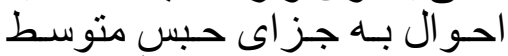

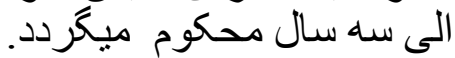

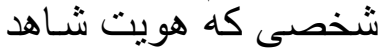

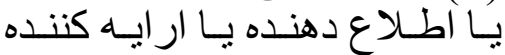

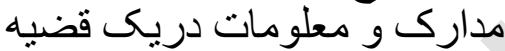

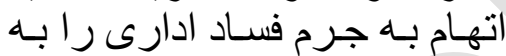

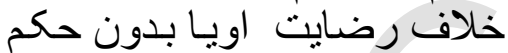

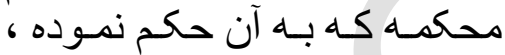

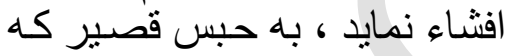

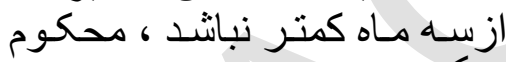
مبكر دد.

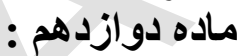

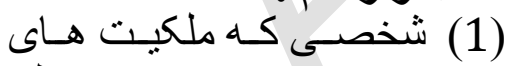
عقارى اعم اززمين هـاى صـالح

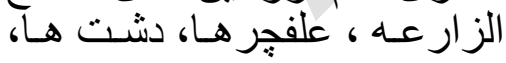

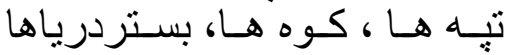

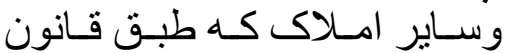

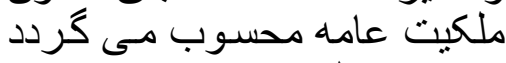

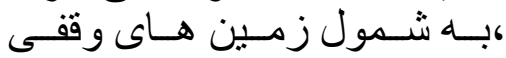

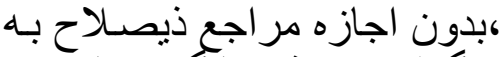

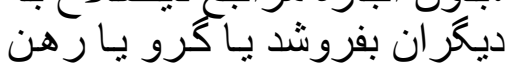

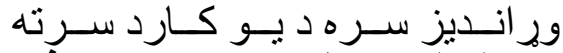
رسولو لياره دبل شخص دون لـه نفوذاو

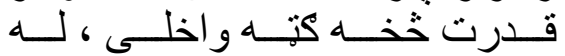

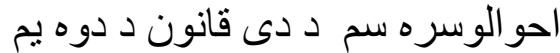

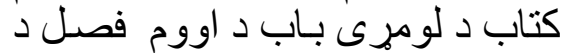

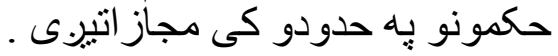
يوولسمه ماده :

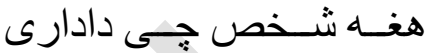

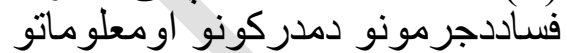

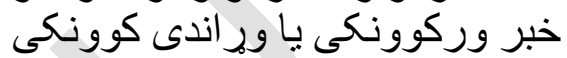

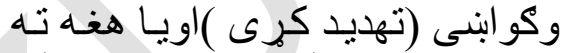

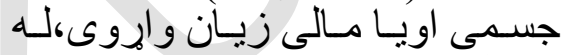

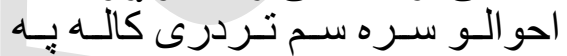

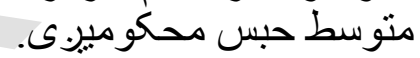

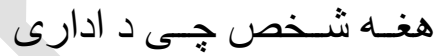

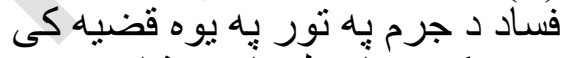

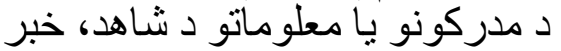

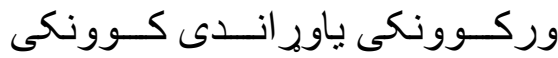

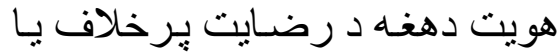

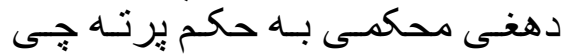

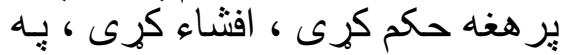

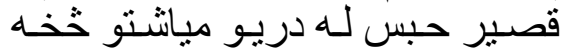
لزبنها وى، محكو ميزلى. دوولسمه ماده مكور :

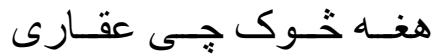

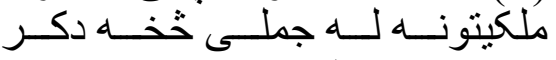

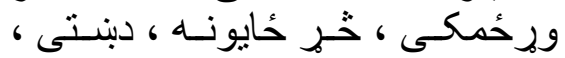

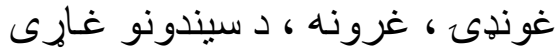

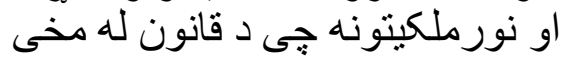


يـا تضمين بـا اجـار ه بدهد ويـا بـه

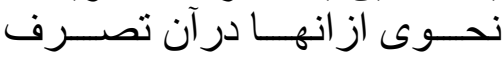

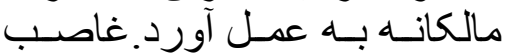

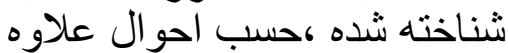

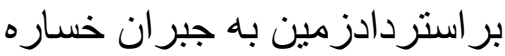

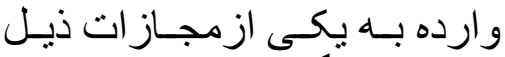

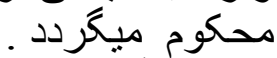

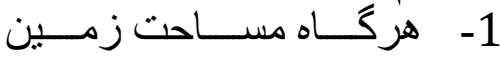
غصب شده الى (3) جريب باثند

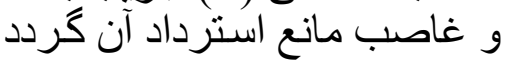

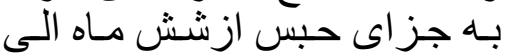
يك سال.

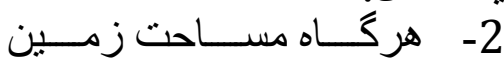

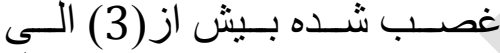

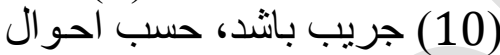
بـه حبس بيش ازيك سال الى ينج سال .

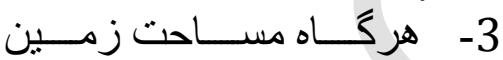
غصب شده بيش از (10) جريب

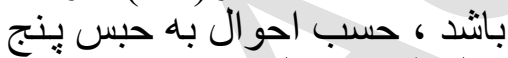

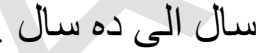

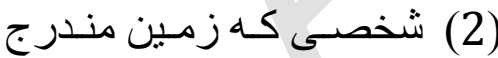

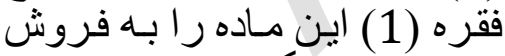

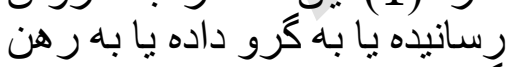

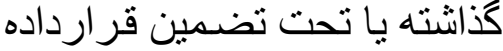

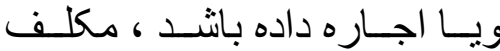

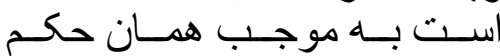

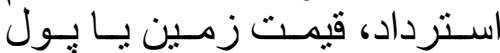

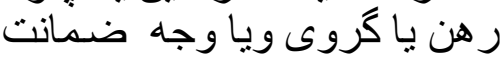
يا اجاره را با به شخصى كهـ زمين

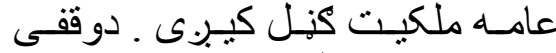

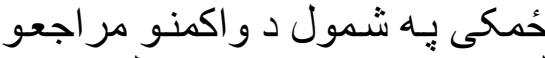

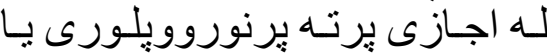

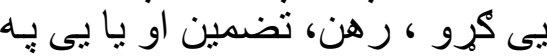

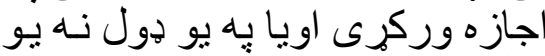

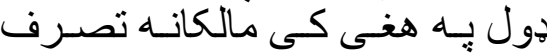

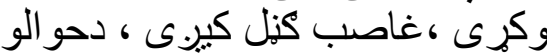

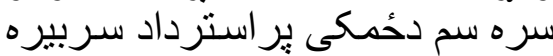

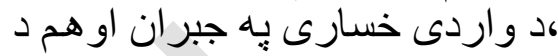

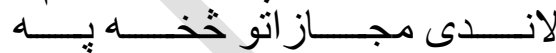

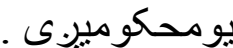

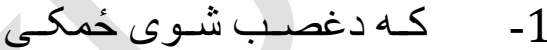

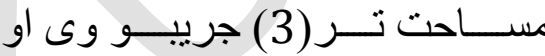

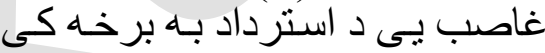

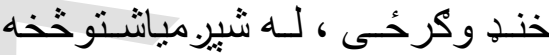
زياد تريوه كال يه وبه حبس.

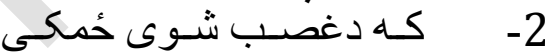

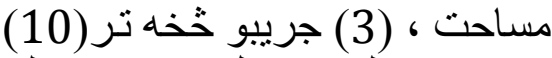

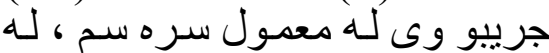

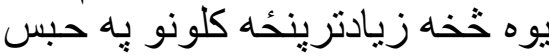

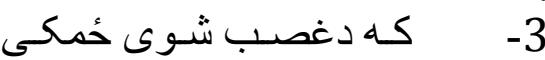

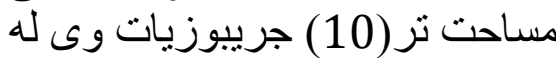

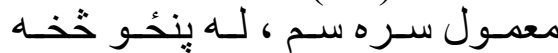
ترلسوكلونو بيه حبس .

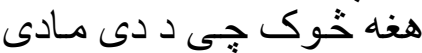

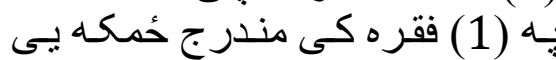

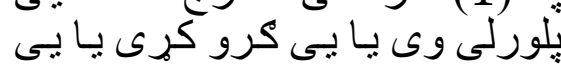

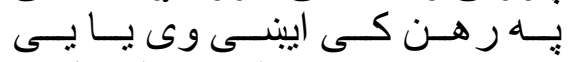

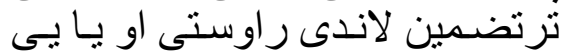


ازوى مسـترد شــــه اســت تاديـه

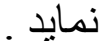

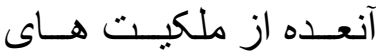

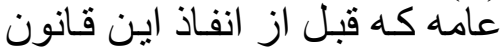

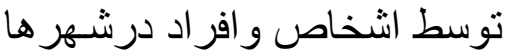

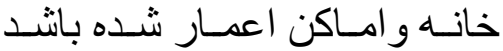

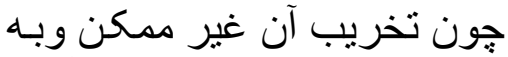

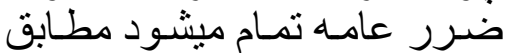

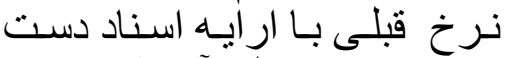

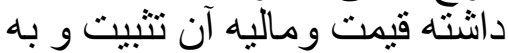

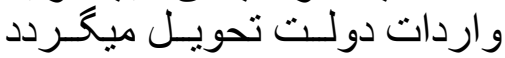

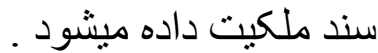

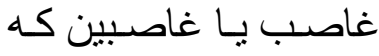

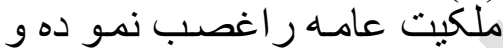

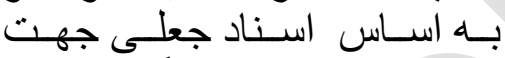

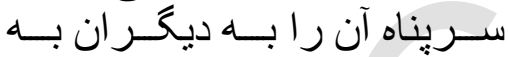

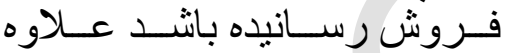

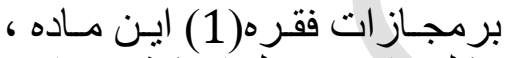

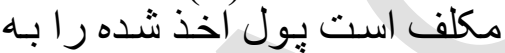
حساب دولت بير دازد د.

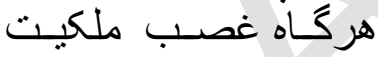
هاى مندر ج فقره (1) اين مـاده

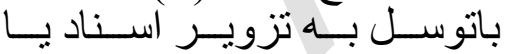

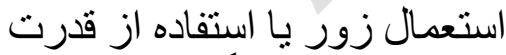

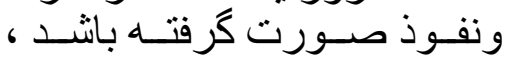

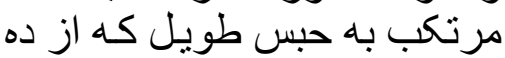

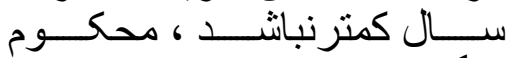

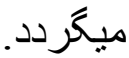
(6) احكــام منــدر ج ايـنـ مــاده

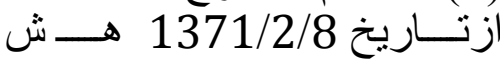

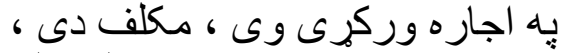

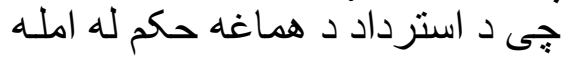

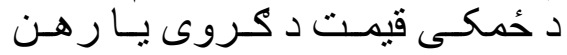

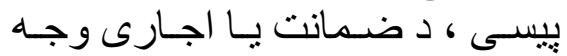

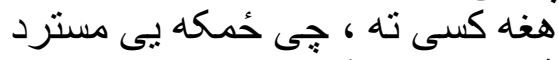

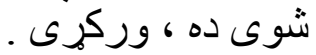

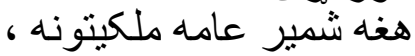

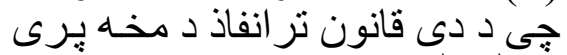

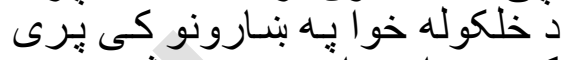

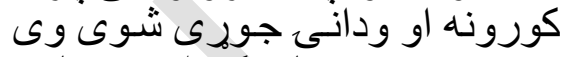

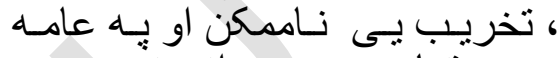

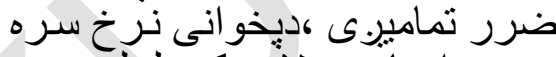

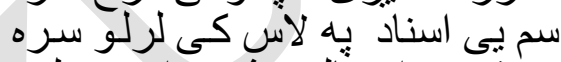

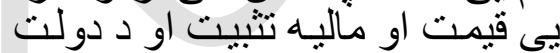

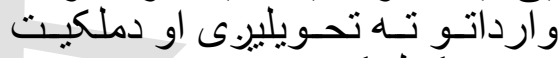

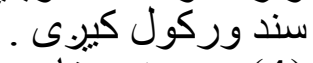

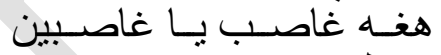

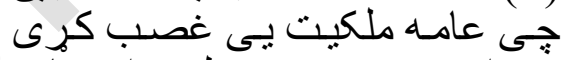

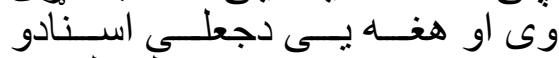

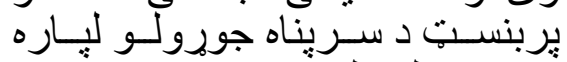

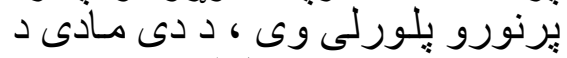

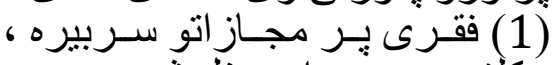

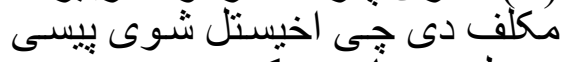

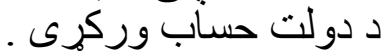

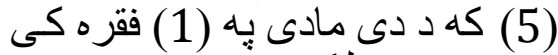

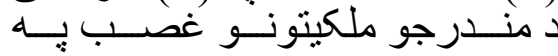

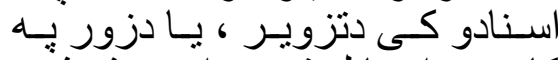

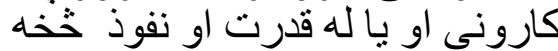

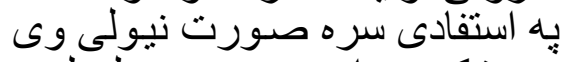

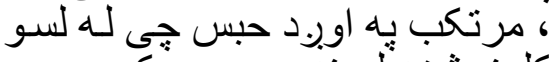

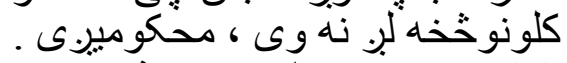

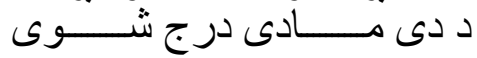


ضمايم شماره (†) و (ه) قانون جزاء

قضياءو

قابل تطبيق مبياشد .

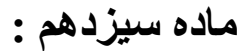

اين ضميمه ازتناريخ نوشيح

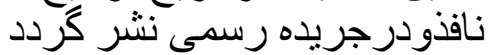

فرمان

رئيس جمهورى اسلامى فرمان

افغانستان درمورد توشيت موريح فيصله هيأت مختلط مجلسنين

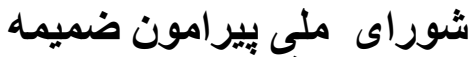
شماره (5) قانون جزاء منون منتشره جريده رسمى شماره (5.رن (357)

سال1355 درمورد جرم اختطاف

(184): شماره

تاريخ :1395/10/16)

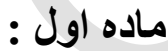

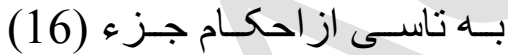

ماده (64) وفقره(2) ماده (100) (10) (16)

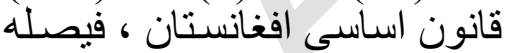

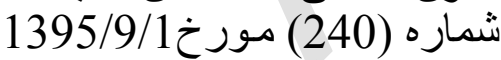

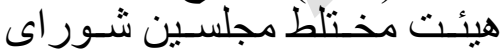

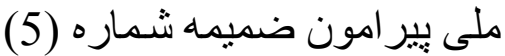

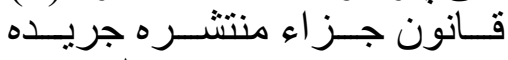
رسمى شماره (347) سال 1355

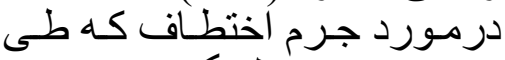

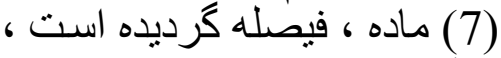
توشيح مهى دارم.
حكمونه له 1371/2/8 هـ ش نيتى دي دي

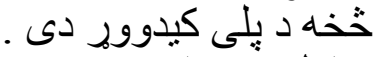
ديارلسمه ماده دئه

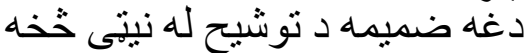

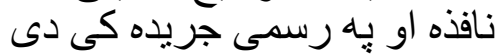
خِيره شى.

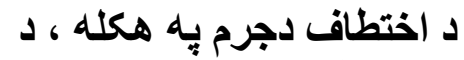

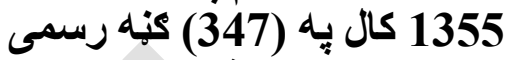

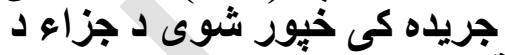

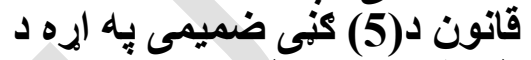

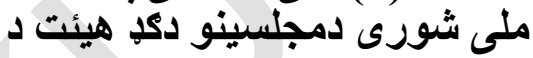

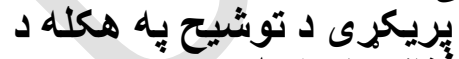

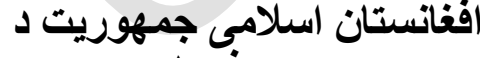
رئيس فرمان

كنيه (184) نيتّه : 1395/10/16 كيه (184)

لومرى ماده :

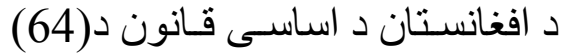

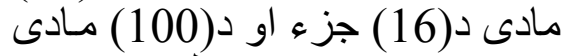

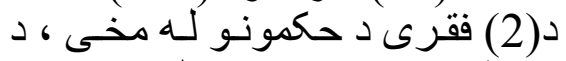

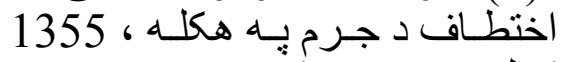

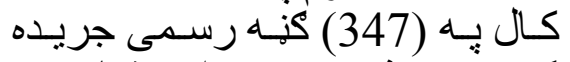

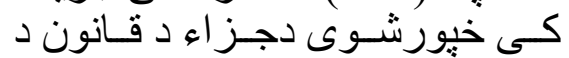

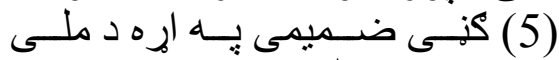

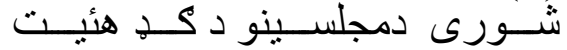

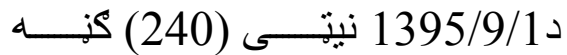

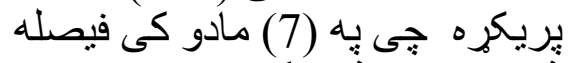
شوى ده ، توشيح كوم . 
اين فرمان از دوم تاريخ توشيح نافذ

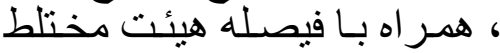

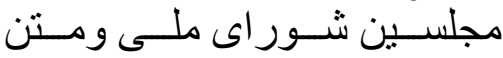

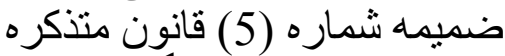

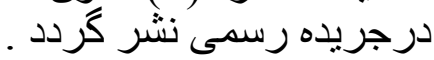

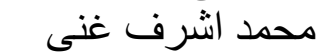
رئيس جمهورى اسلاميى فنى افغانستان

ضميمه شماره (5) قانون جز اء

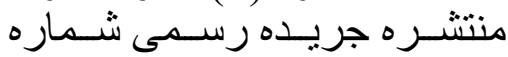

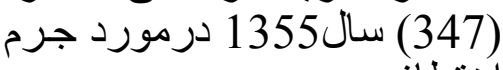
اختطاف

\section{تعريف اختطاف}

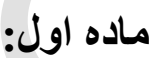

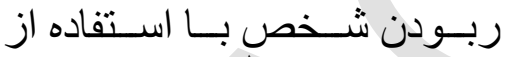

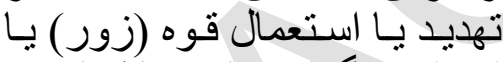

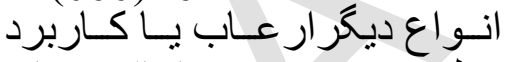

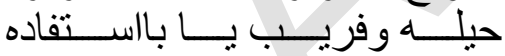

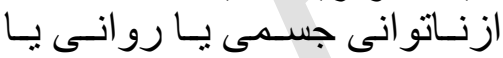

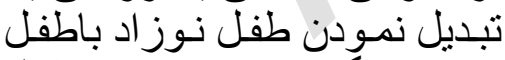

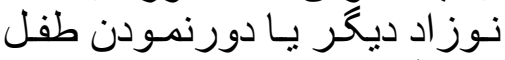

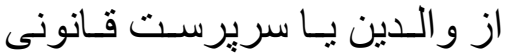

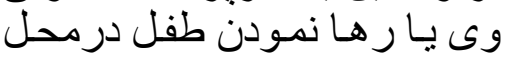

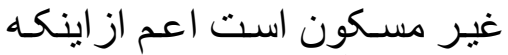

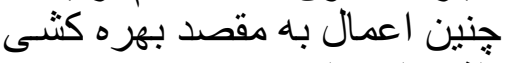

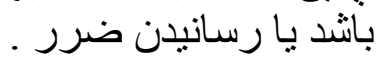

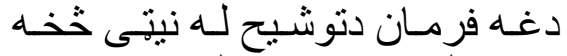

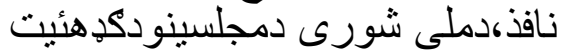

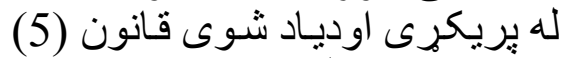

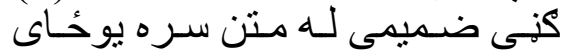

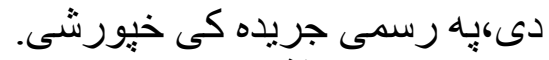
محمد اشرف جن غنى

د افغانستان جمهوريت رئيس

د اختطاف دجرم يه هكله ، د د 1355

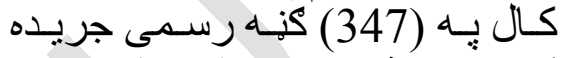

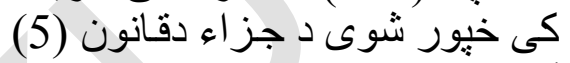
كنه ضميمه خيور

\section{دـ اختطاف تعريف}

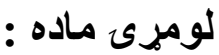

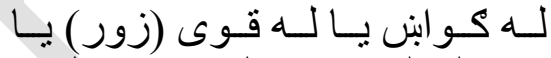

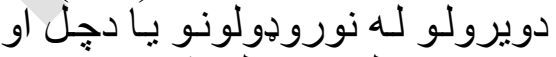

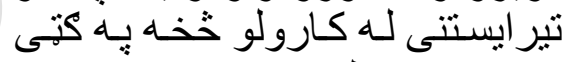

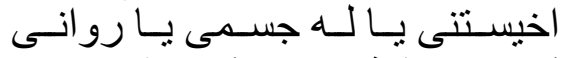

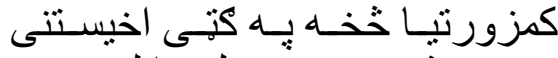

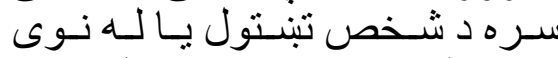

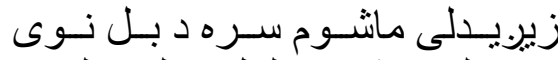

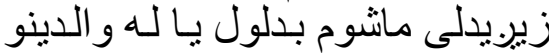

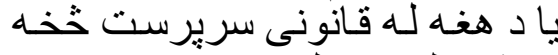

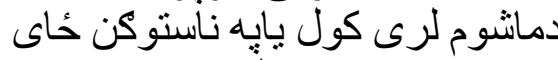

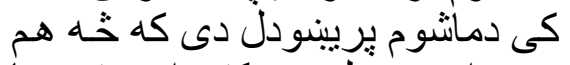

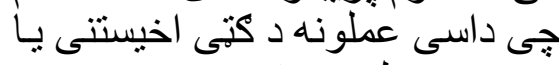

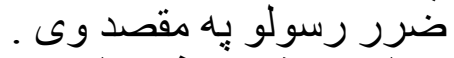

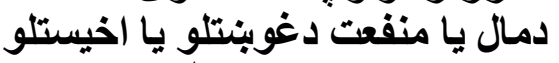

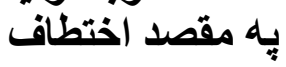


ضمايم شماره (+٪) و (ه) قانون جزاء

قَغناءو

اختطاف باه مقصد مطالبه يا اخذ

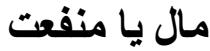

ماده دوم :

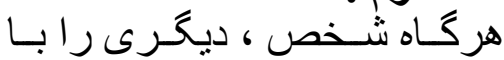

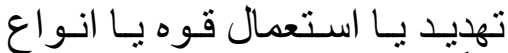
ديكر ار عاب يا با استفاده ازمو الدهال

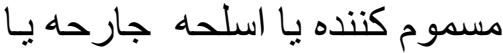

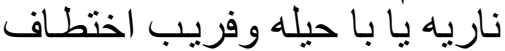

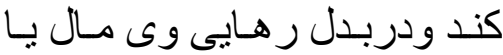

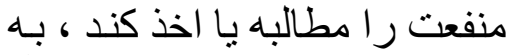

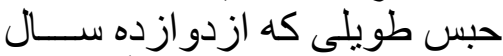

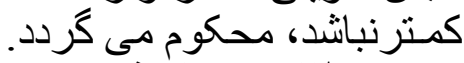

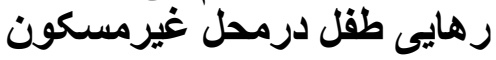

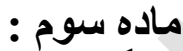

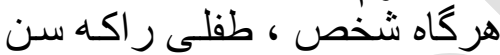

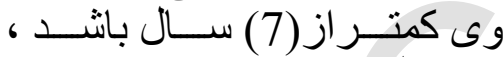

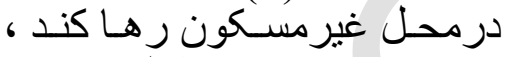

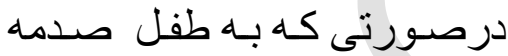

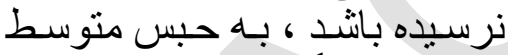

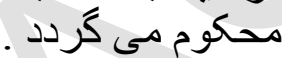
تبديل نمودن طفل نوز طرد ياد ينهان نمودن طقل نوز

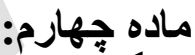

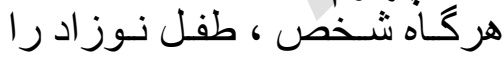

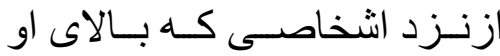

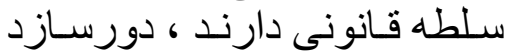

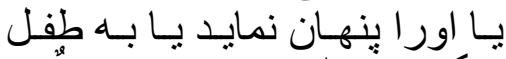

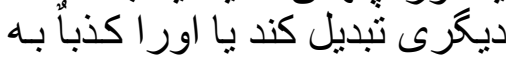

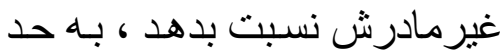

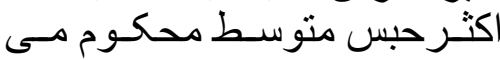

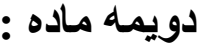

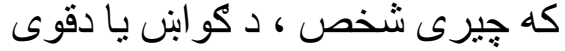

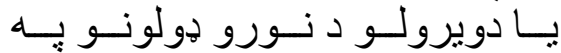

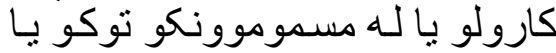

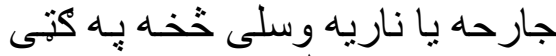

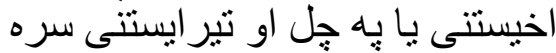

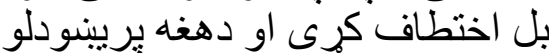

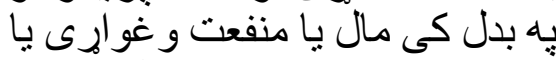

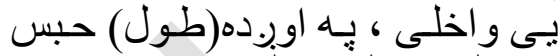

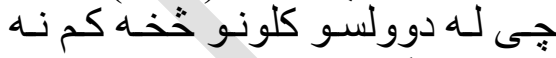

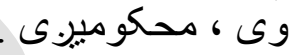
بِه ناستوكن خاى كى دماشوم يزيبنودل جناي

درييمه ماده : ديرئ

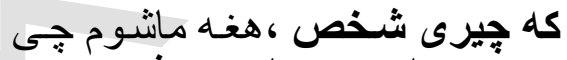

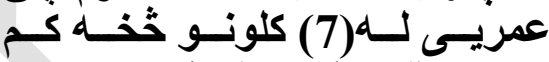

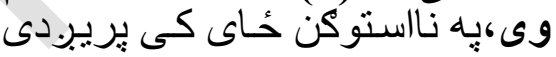

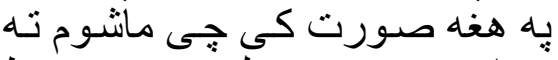

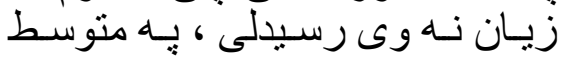

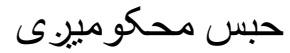

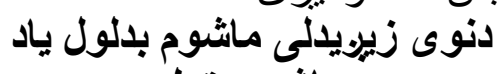

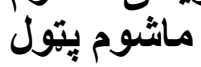

خُلورمه ماده : ماتوم:

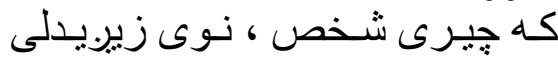

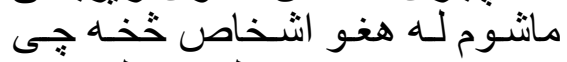

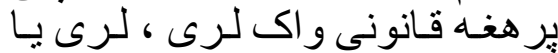

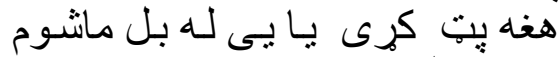

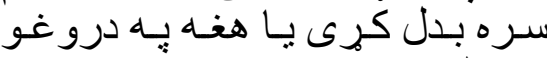

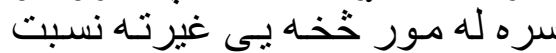

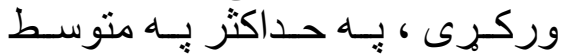




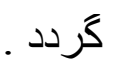

\section{حالات مشدده اختطاف}

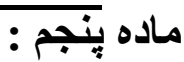

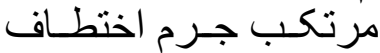

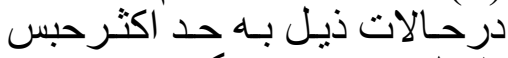

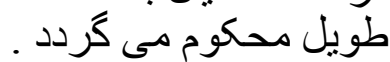

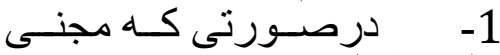

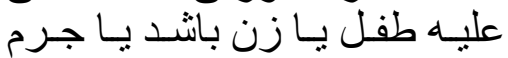
توسـط مسـتخدم مجنـى عليـهـ يــا

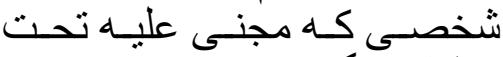

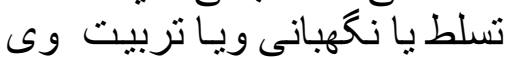

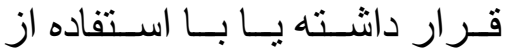

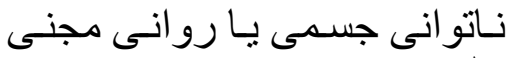

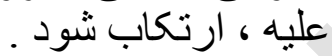

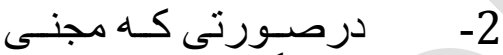
عليه ازطريق كماثتن بـه فعاليـ

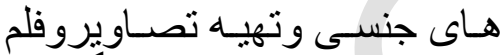

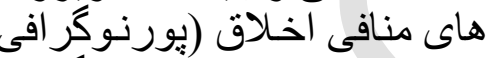

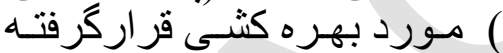

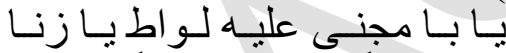

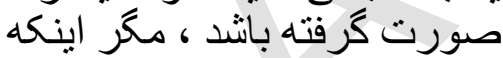
تطبيق شر ايط حد تحقق نيابد.

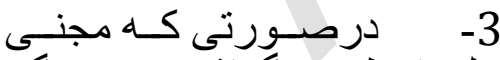

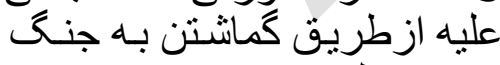

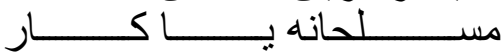

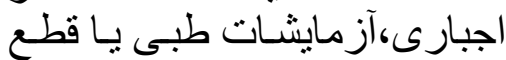

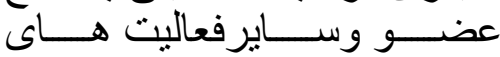

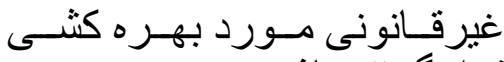
قر اركر فته باثند . هرك
حبس محكو ميزى . دـ اختطاف مشددى حالات ينحمه ماده :

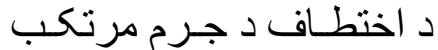

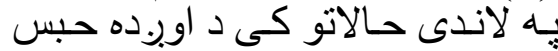

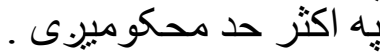

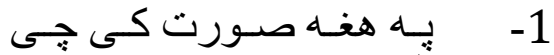

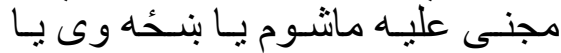
جرم د مجنى عليه دمستخدم يـا هغنه ليها

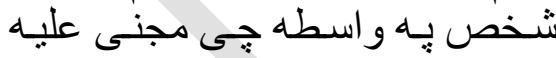

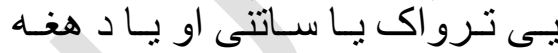

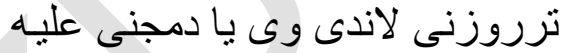

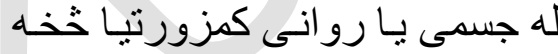
به كتى اخيستنى سره ، ارتكاب شيى

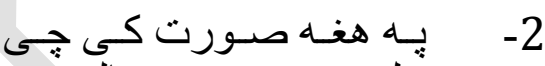

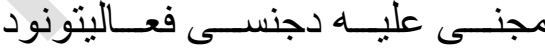

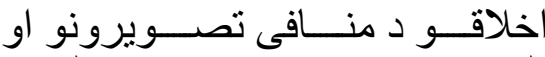

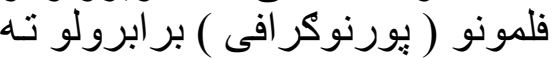

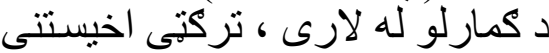

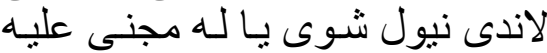

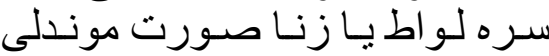

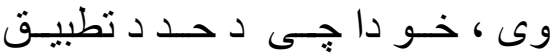
شر ايط تحقيق ونه دو دو دى .

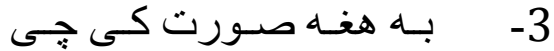

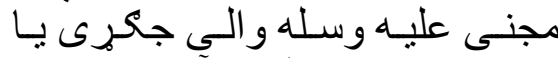

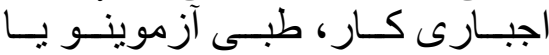

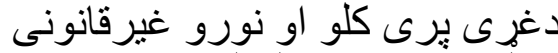

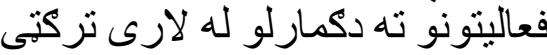

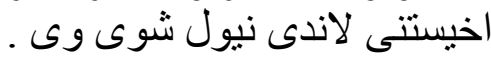


باســتفاده از وســايط يــا اســلحهـ

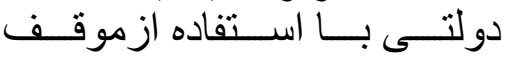

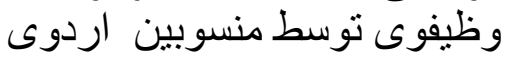

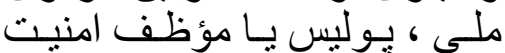

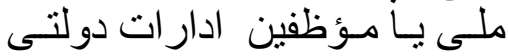

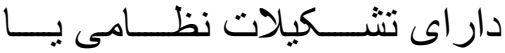

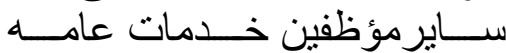

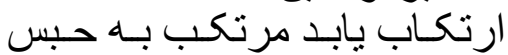
دوام محكوم مى كردي مرد .

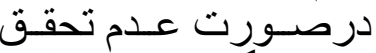

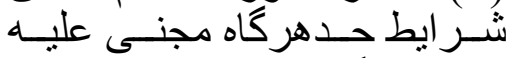

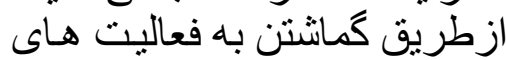

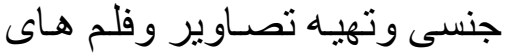

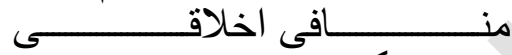

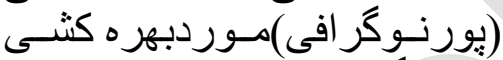

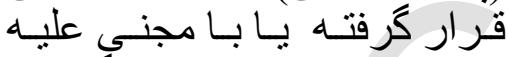

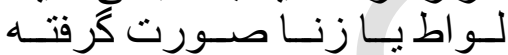

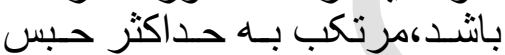

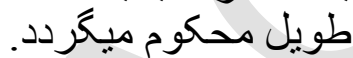
فوت يا قطع عضومجني عليه عزيه درنتيجه اختطن فضومنفي ماده شُشّم : مانج

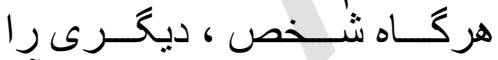

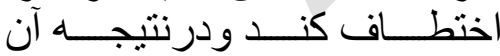

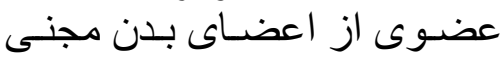

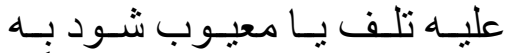

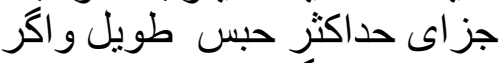

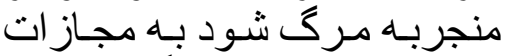
قتل عمد محكوم مـى كردد . انفاذ :

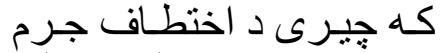

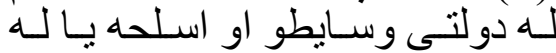

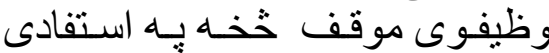

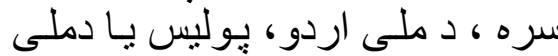

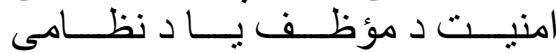

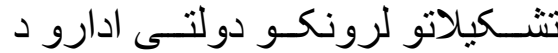

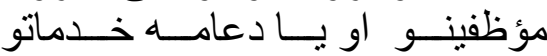

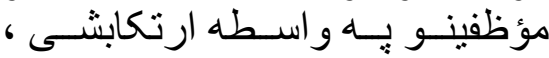
مرتكب يه دو ام حبس محكو ميزئى .

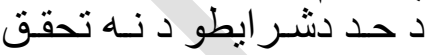

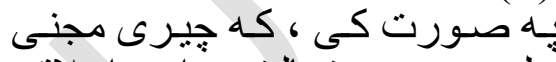
عليه د جنسى فعـاليتونو او د اخلاقو

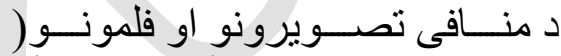
يورنوكر افى ) بر ابرولو ته دكمارلو الون

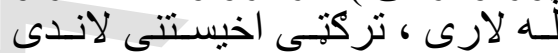

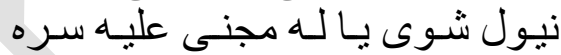

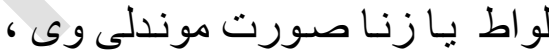

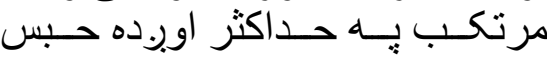

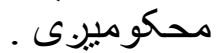

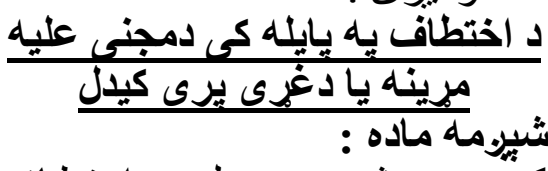

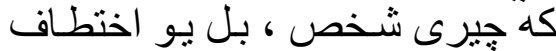

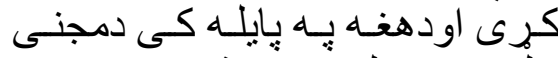

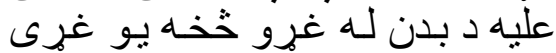

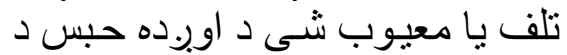

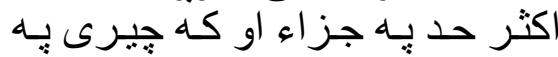

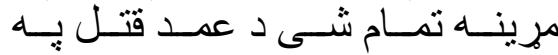

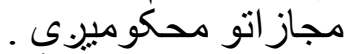
انفاذ 


\section{ازمتحدالماللهاى ستره محكمه}

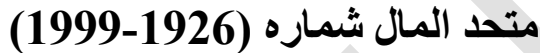

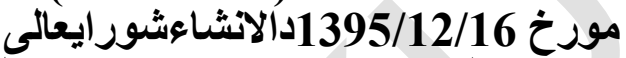

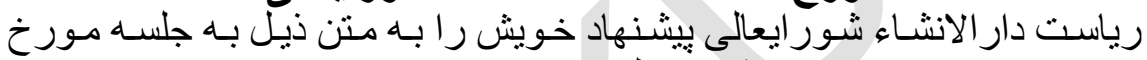

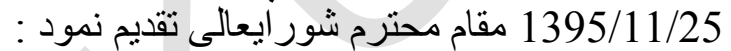

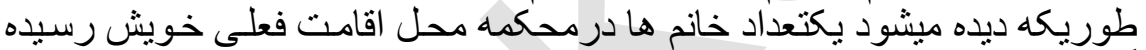

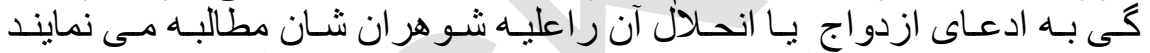

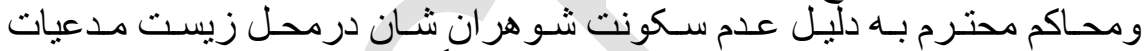

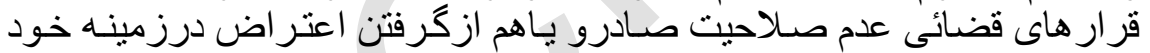

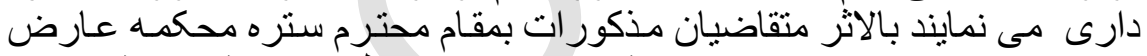

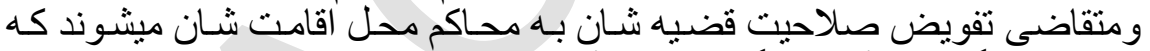

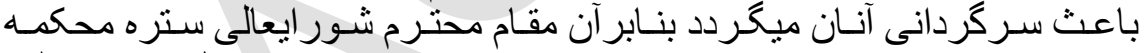

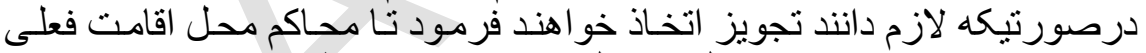

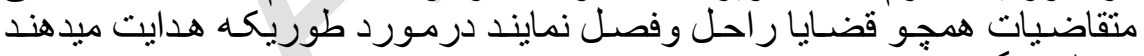

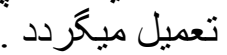

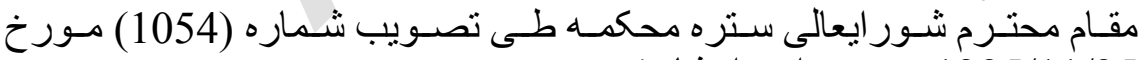

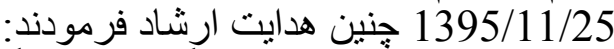

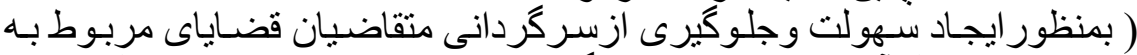

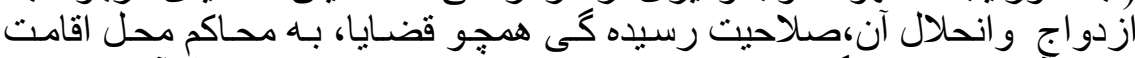

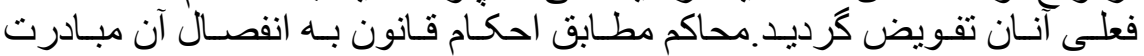

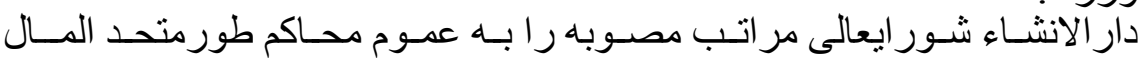

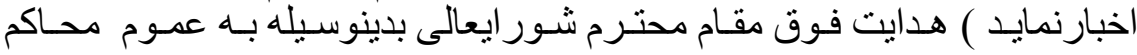




\section{بررسى نقش زن در خانواده و اجتماع}

نحمدها : نصلى على رسوله له الكريم، اما بعد:

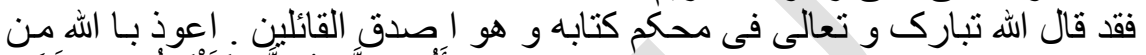

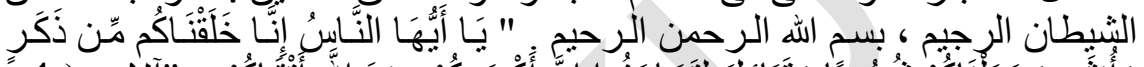

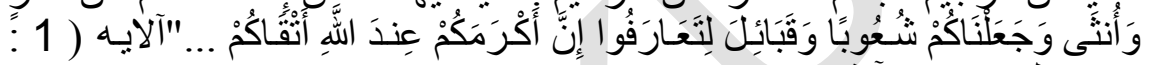

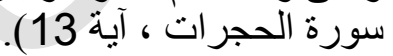

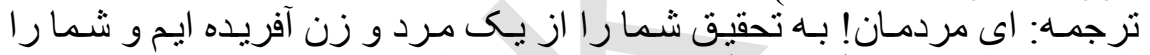

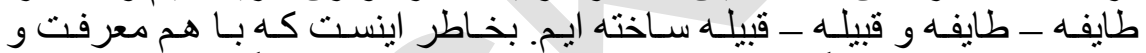

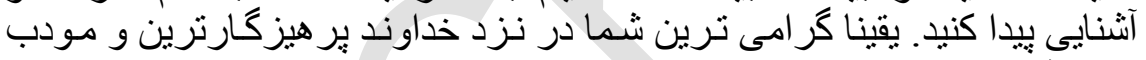
ترين شماست. و قال رسول الله (ص) "المسلمون إخوة لا فضل لا حدعلى ا حد الا بـالتقوى" ، ألحديث (5 : 141: (14).

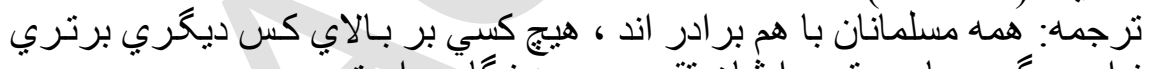

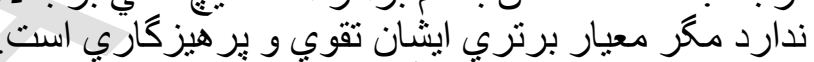

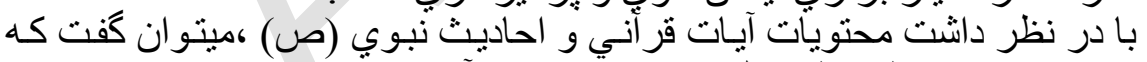

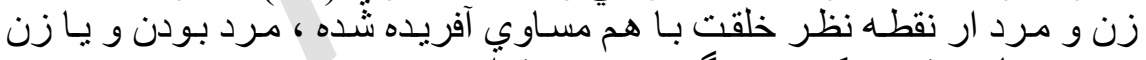

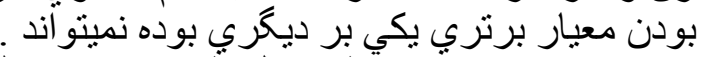

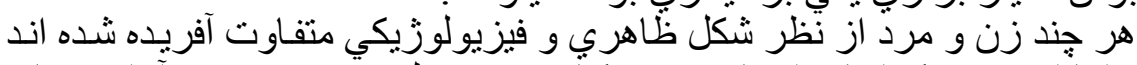

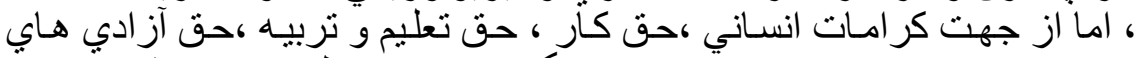

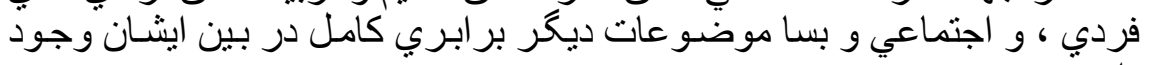
دارد. البته تساوي زن و مرد در ماده ب ب قانون اساسي ج.ا.ا نيز بعبار ات ذيل تسجيل

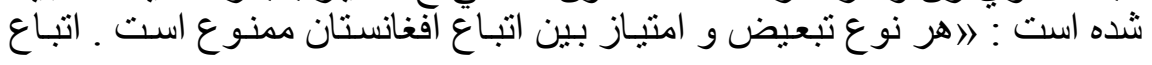


افغانسـتان اعـم از زن و مـرد در بر ابـر قـانون داراي حقـوق و وجايـب مسـاوي ميباشندها (6 : 26 26).

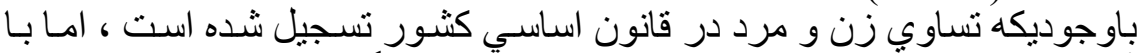

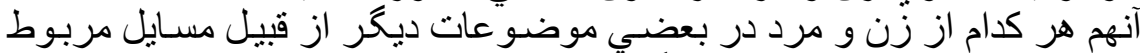

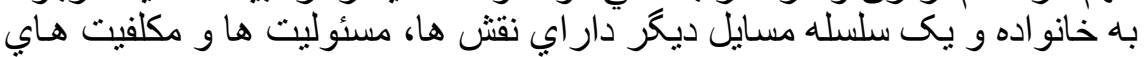
متفاوت ميباشند.

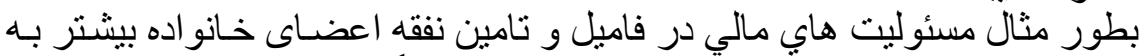

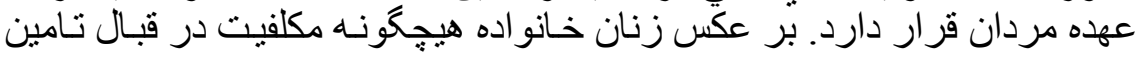

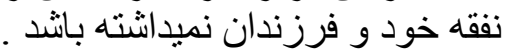

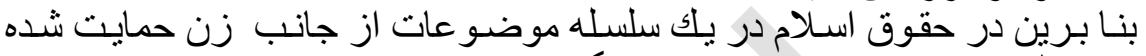

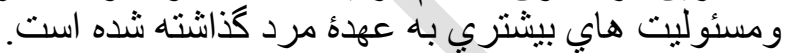

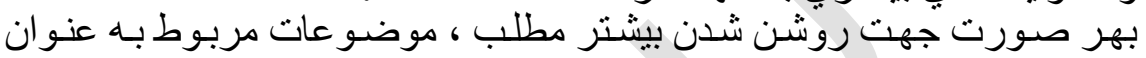

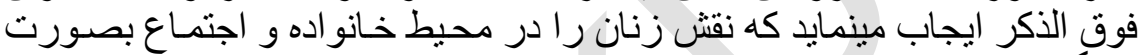

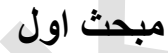

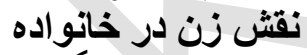

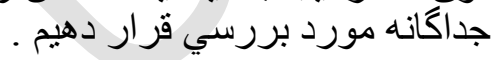

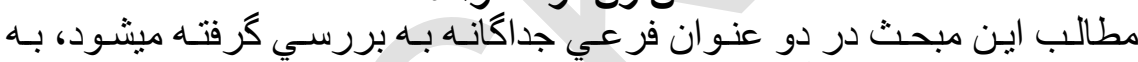

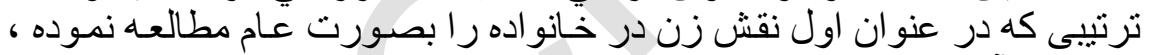

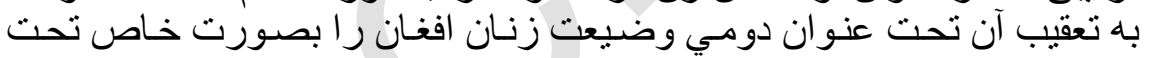

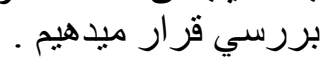

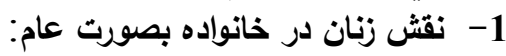

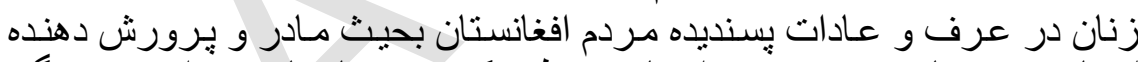

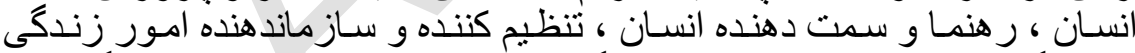

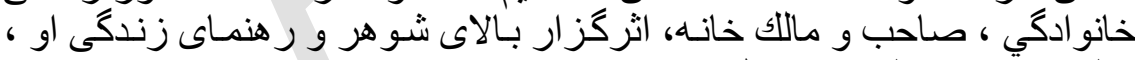

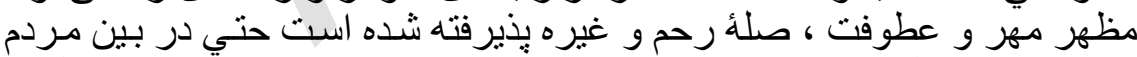

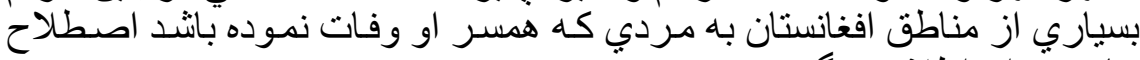

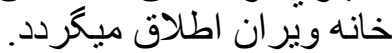

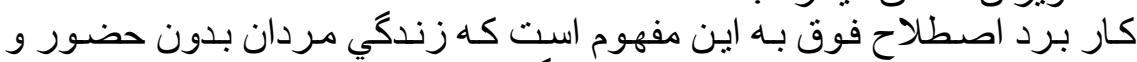

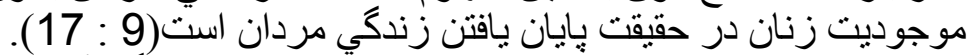

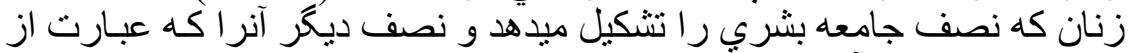

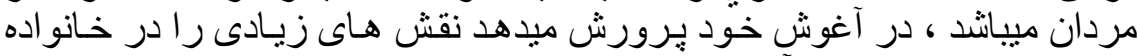

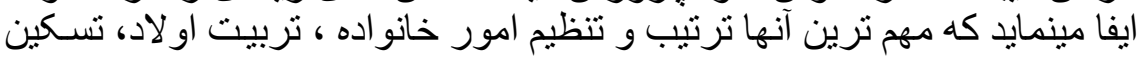


خاطر اعضـاى خانو اده و غيره ميباثـد. بنـا برين هر كدام از موضدو عات فوق

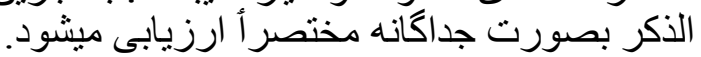

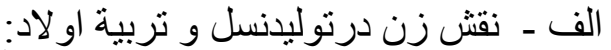

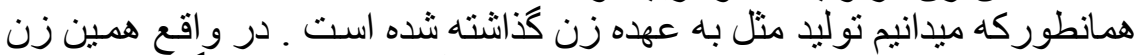

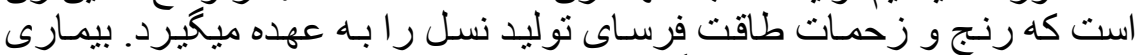

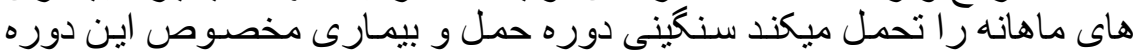

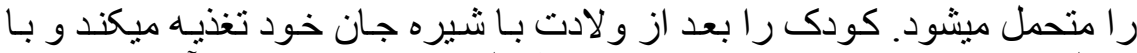

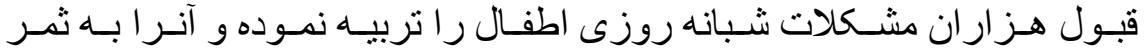

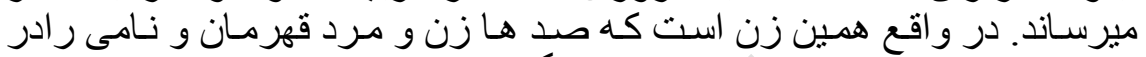

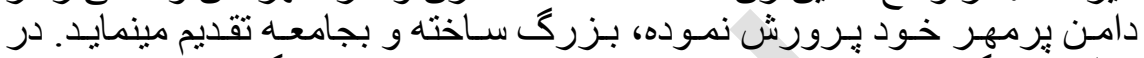

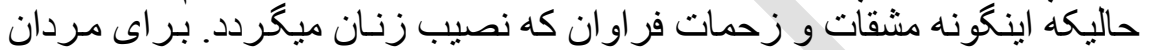

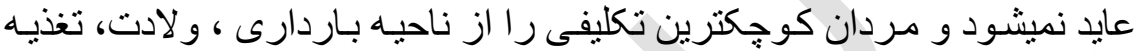

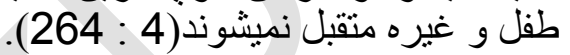

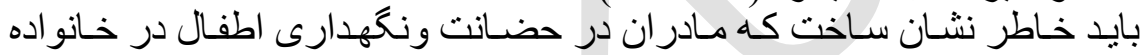

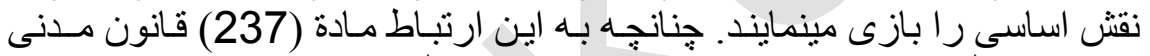

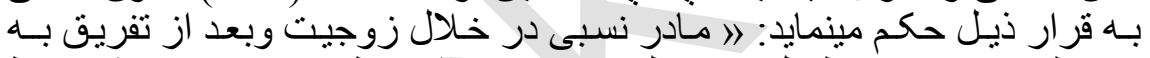

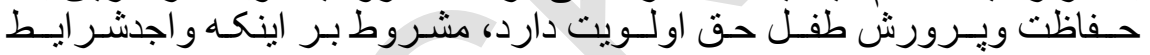

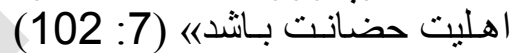

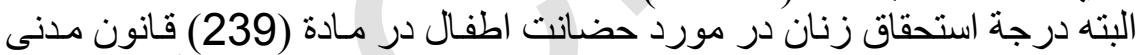

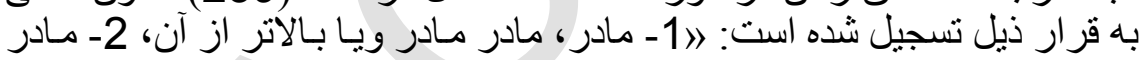

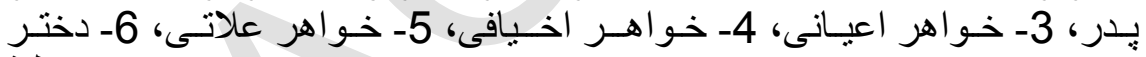

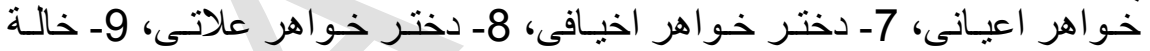

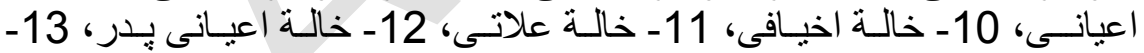

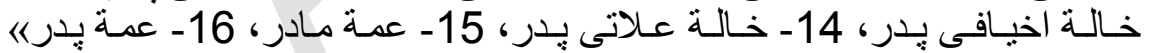
. (103:7)

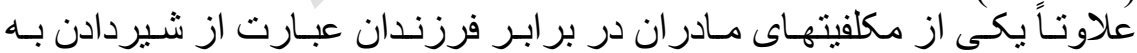

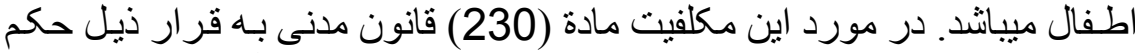

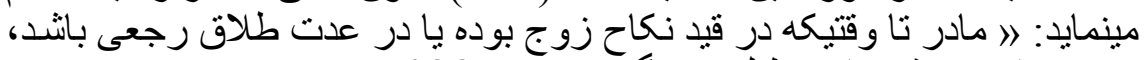

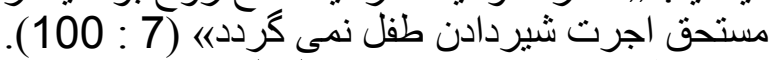

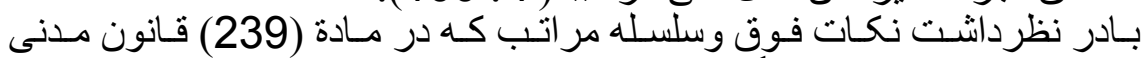

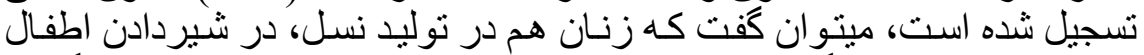

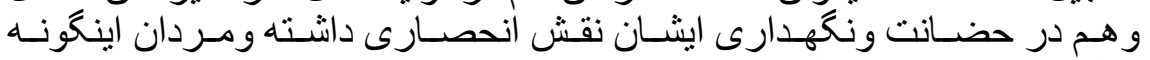
وظايف را بصورت قطع انجام داده نميتو انند. 
ب- نقش زن در ترتيب و تنظيم امور خانو اده:

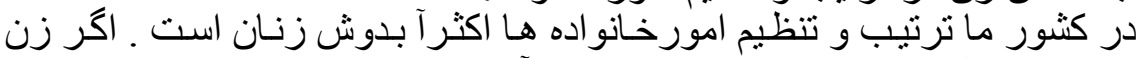

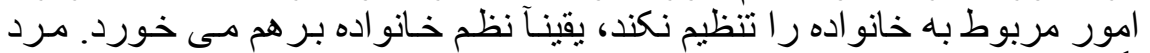

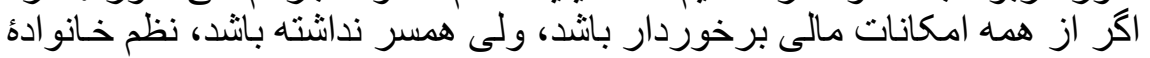

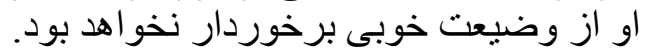

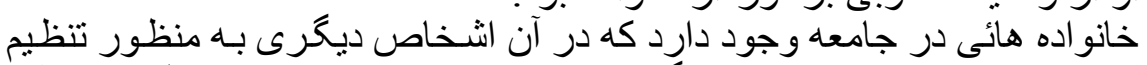

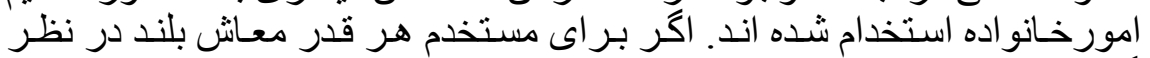

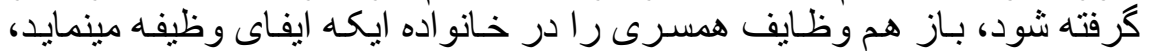

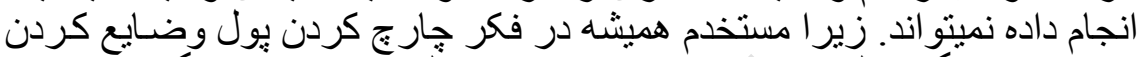

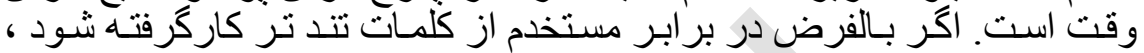

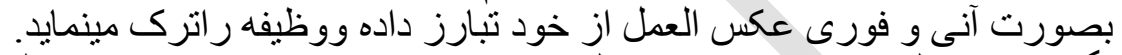

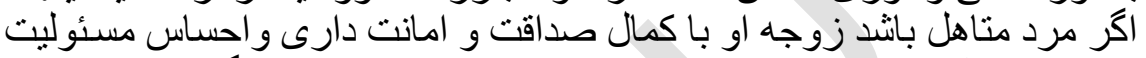

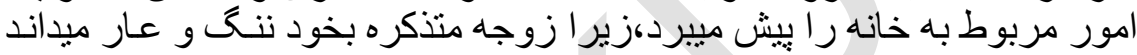

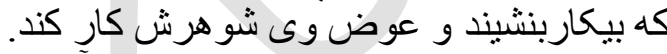

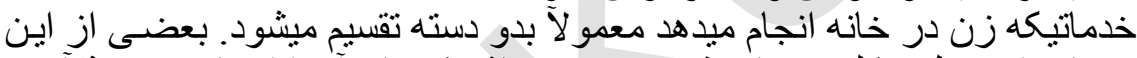

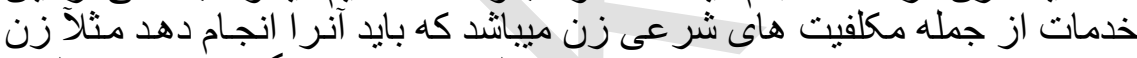

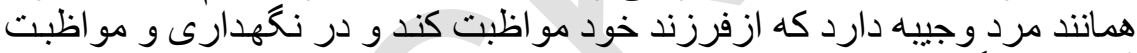

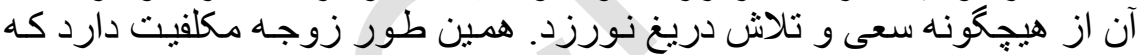

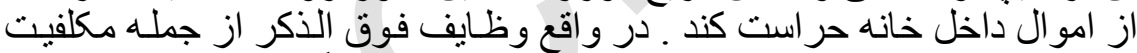

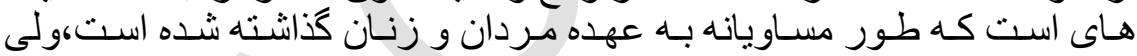

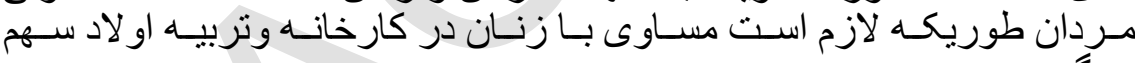

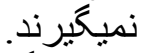
نوع ديكرى از خدمات وجود دارد كه توسط زني در خانه اجر ا ميكردد ، از از قبيل

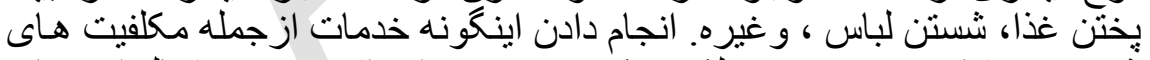

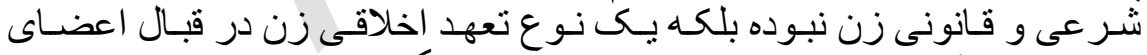

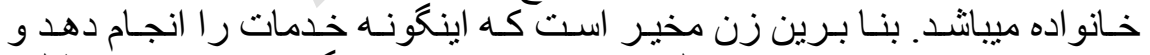

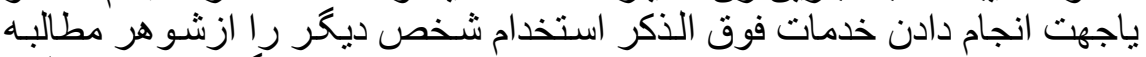

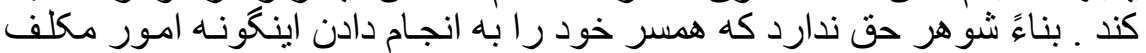
سازد) (8) : 27).

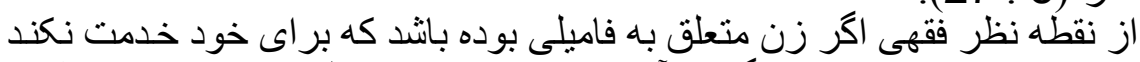

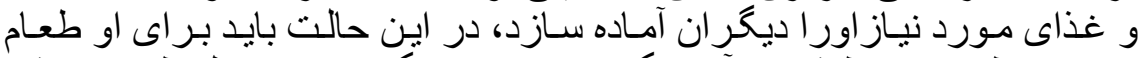

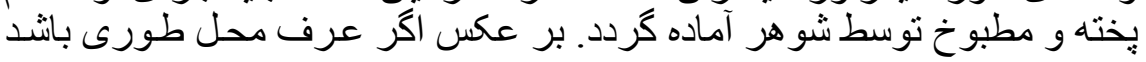


كه زوجه، امور مربوط بـه خودش رد را خود انجام دهد، او وجيبه داردكه غذاى

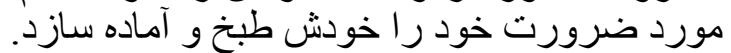

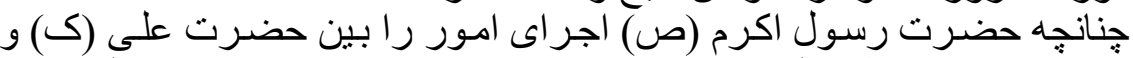

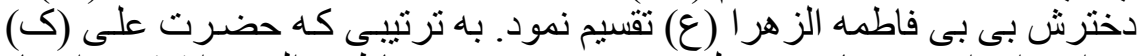

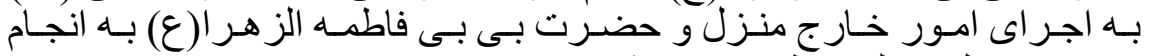

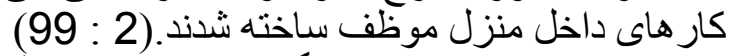

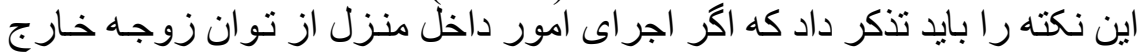

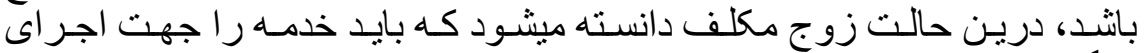

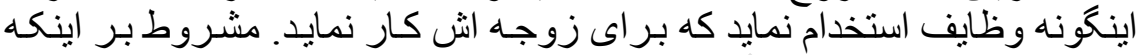

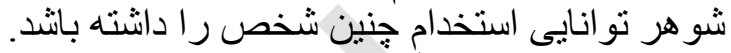

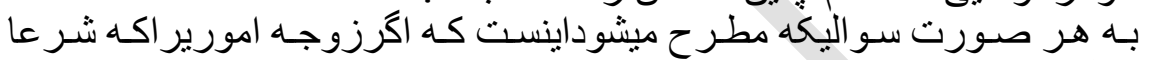

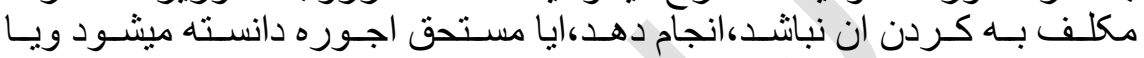

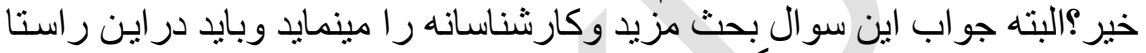

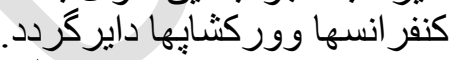

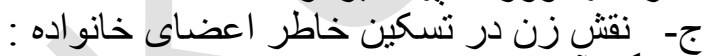

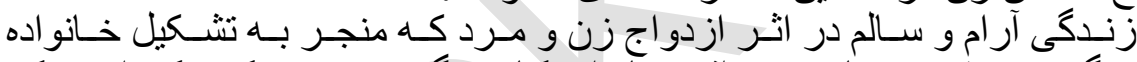

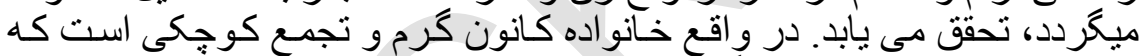

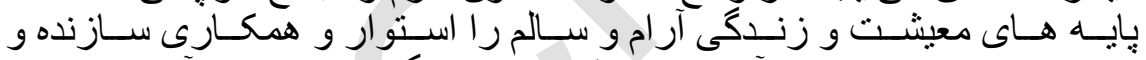

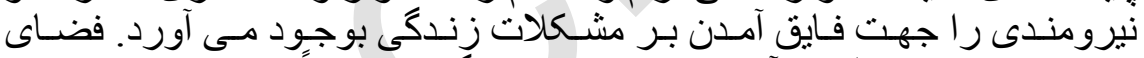

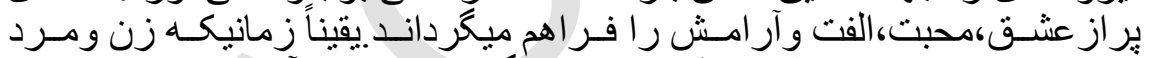

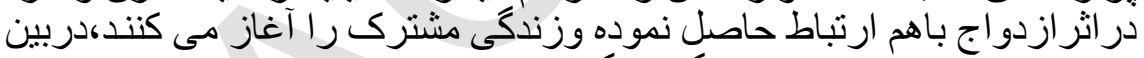

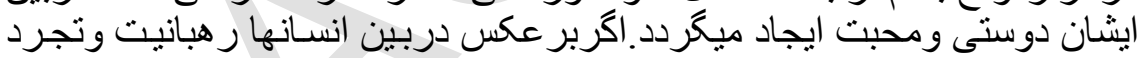

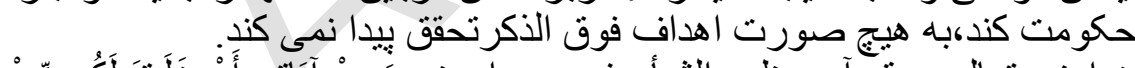

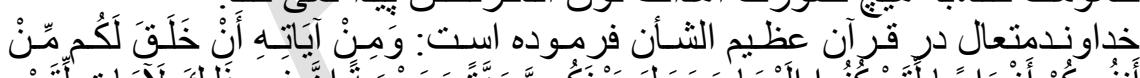

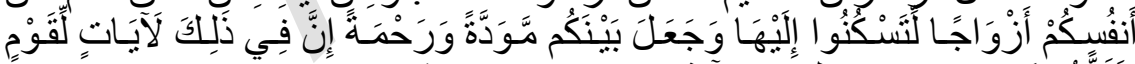

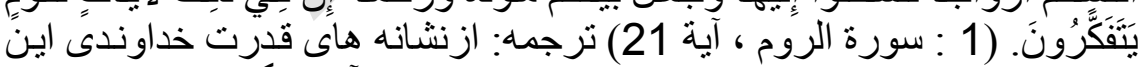

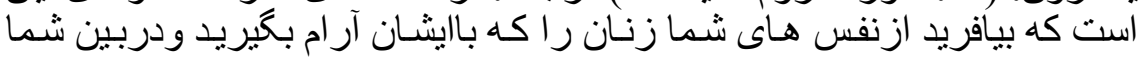

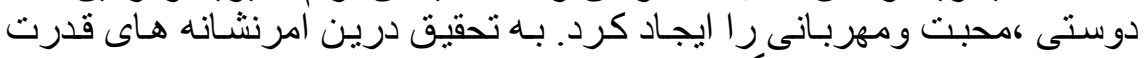

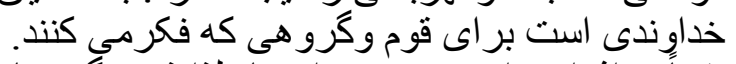

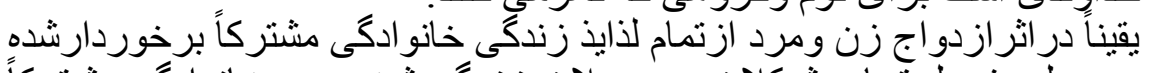

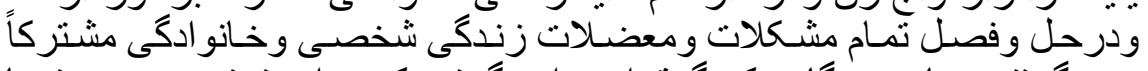

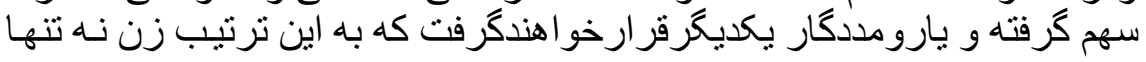


مايـه تسـكين خـاطر مـرد ،بلكـه مايـه تسـكين خاطرتمـام اعضـاى خـانو اده شـرده

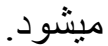

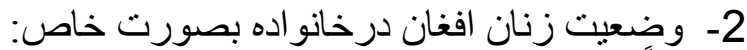

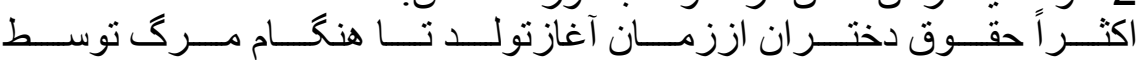

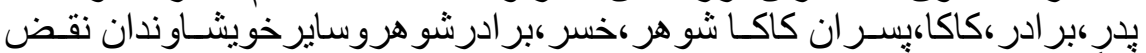

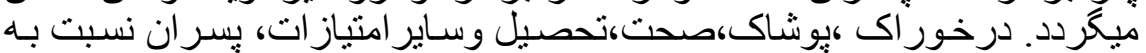

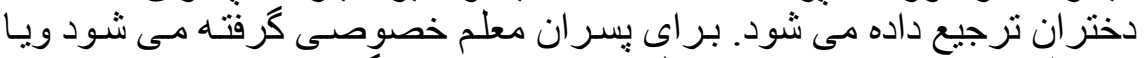

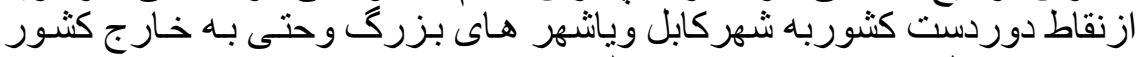

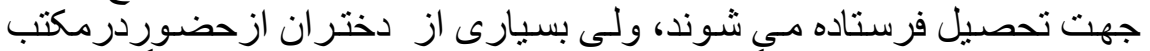

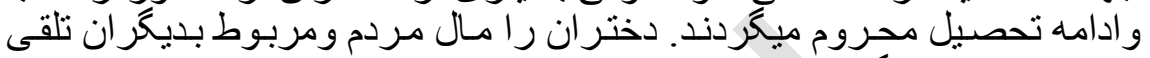

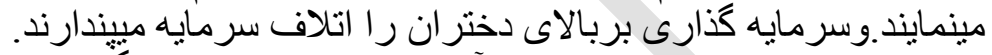

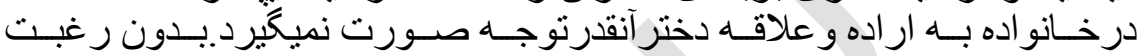

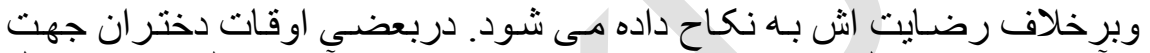

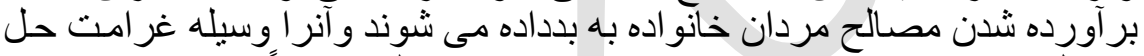

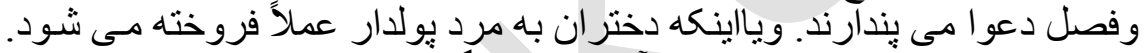

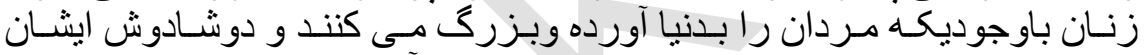

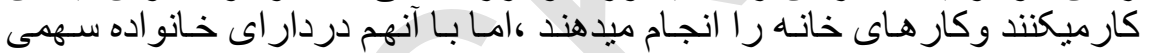

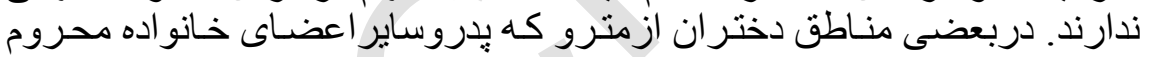
شناخته مى شوند درند.

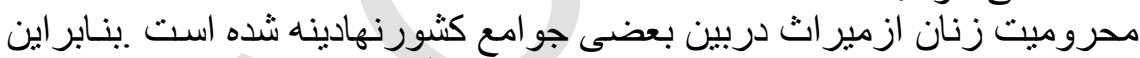

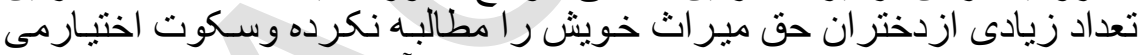

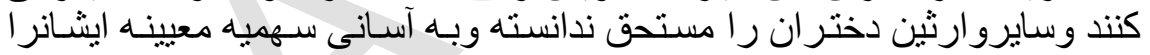

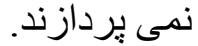

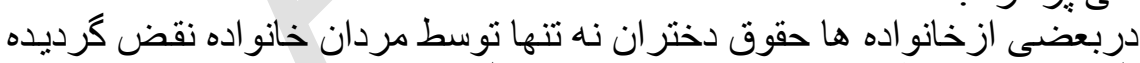

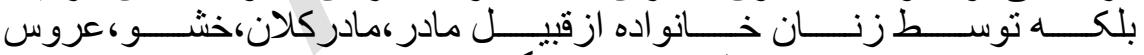
،خو اهربر ادروسايرزنان فاميل نيزنقض ميكُردد. 


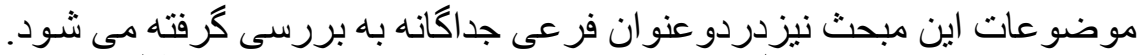

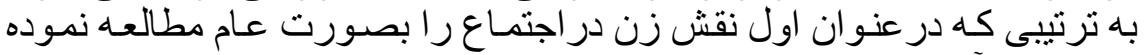

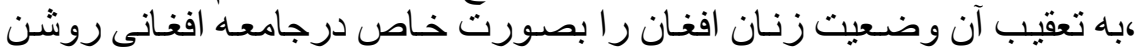

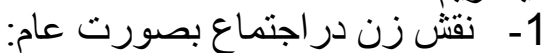

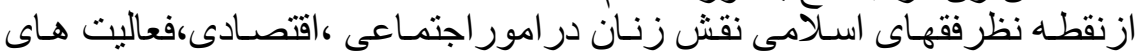

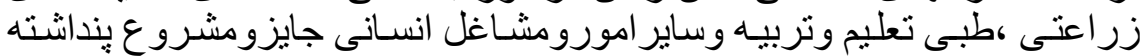

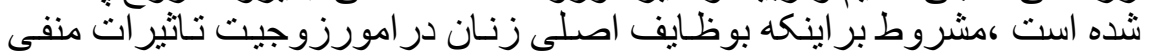
وارد نه نمايد.

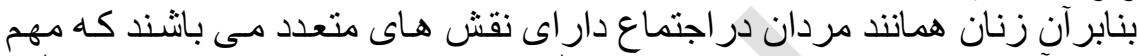

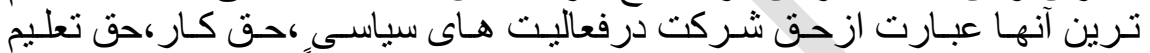

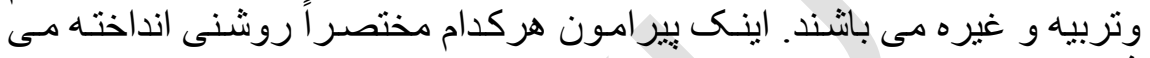

$$
\text { شود. }
$$

الفـ- حق شركت زنان درفعاليت هاى سياسى:

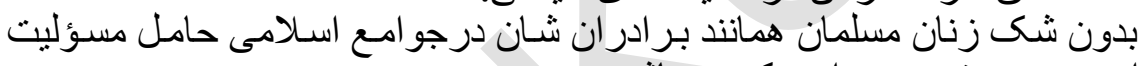

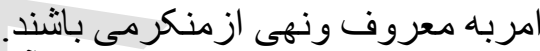

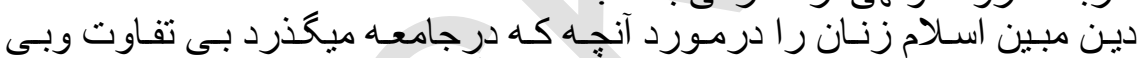

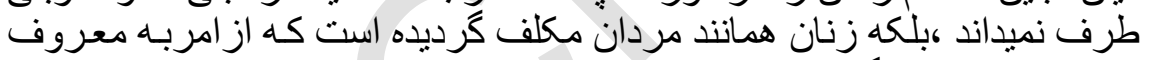
ونهى ازمنكر كاربكيرند.

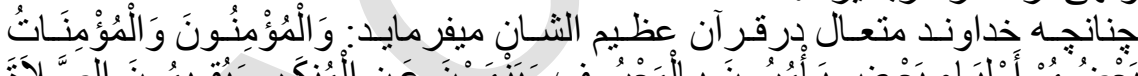

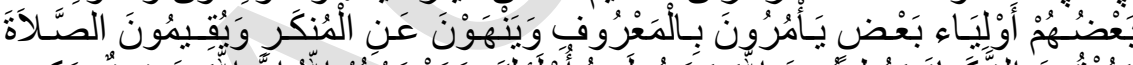

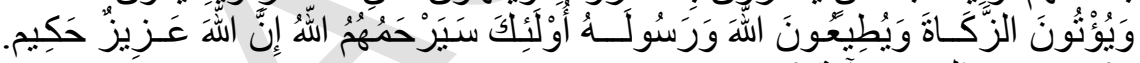

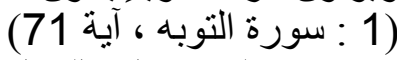

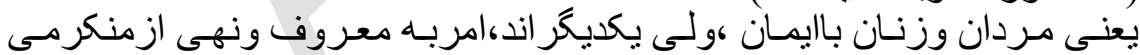

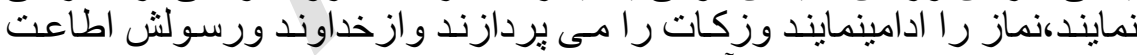

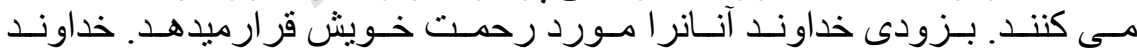
تو اناوحكيم است.

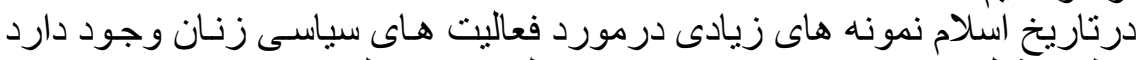

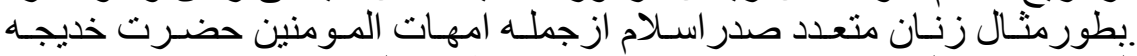

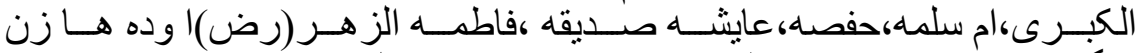

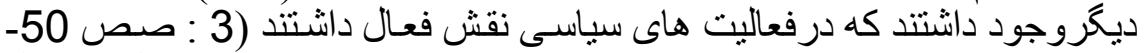

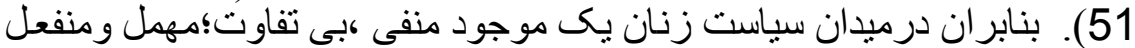

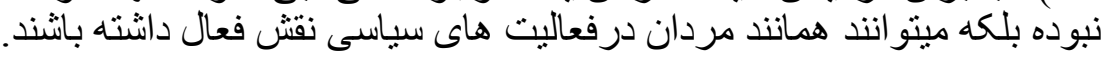




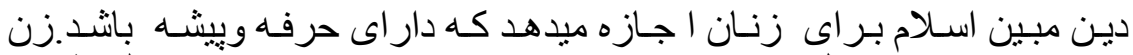

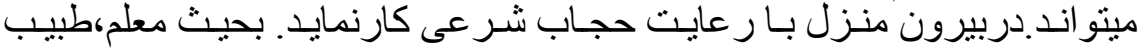

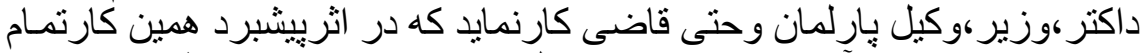

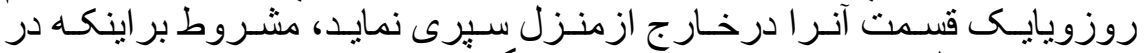

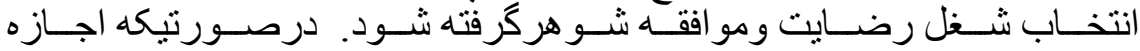

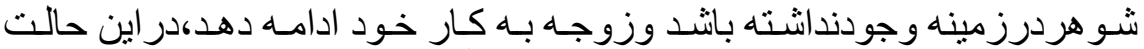

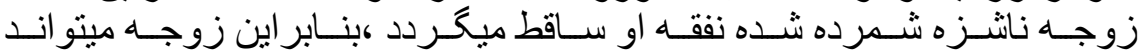

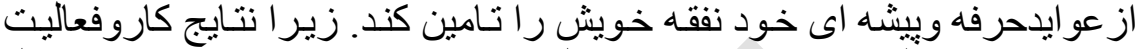

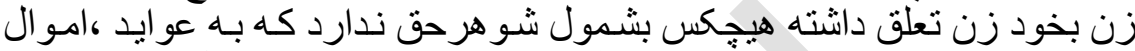

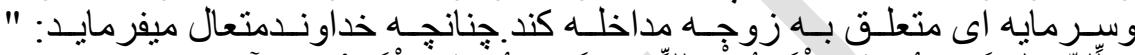

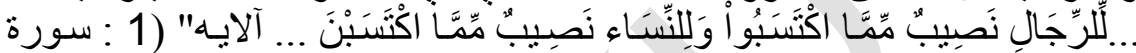

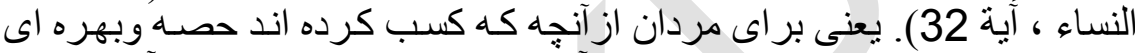

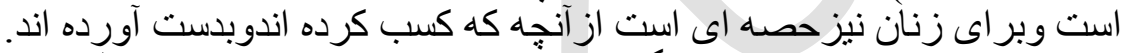

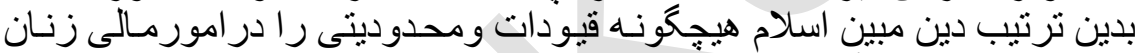

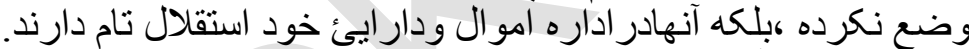

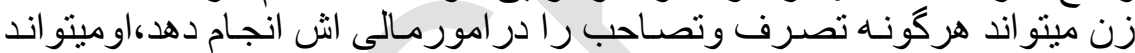

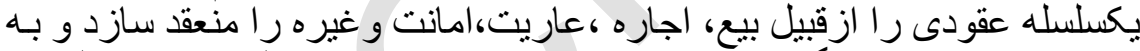

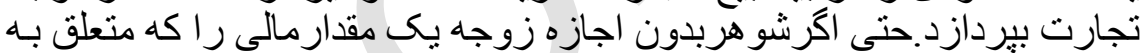

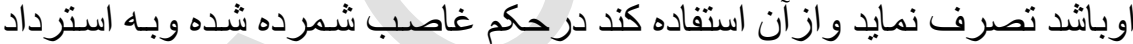

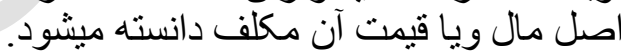

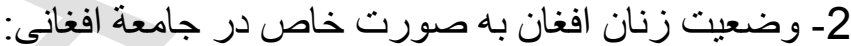

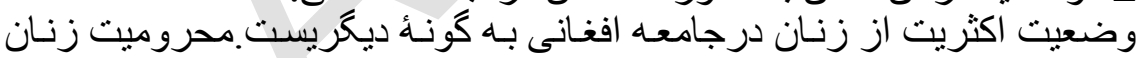

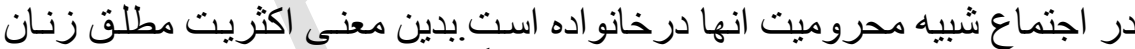

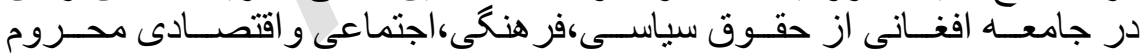

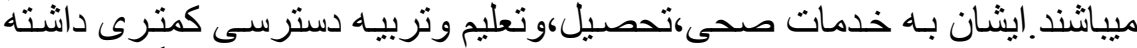

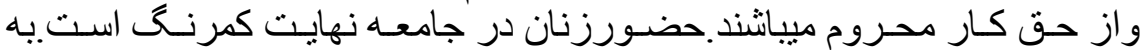

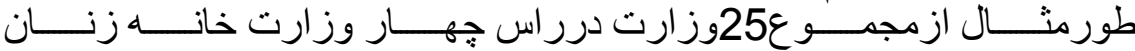

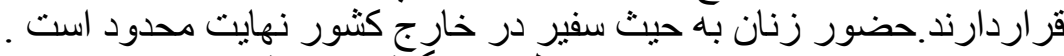

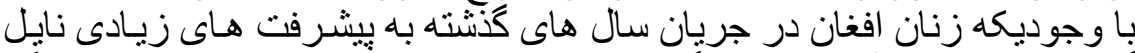

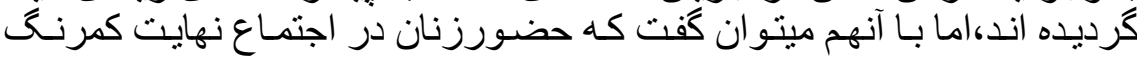


بوده و اكثريت ايثان در جهار ديو ارى خانه محصور بوده وحق اشتخر اك را در

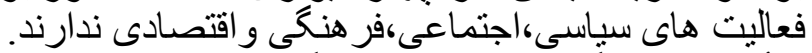

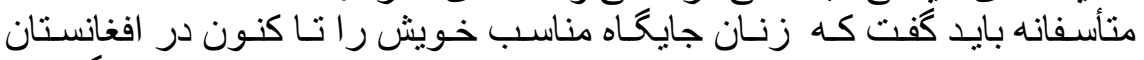

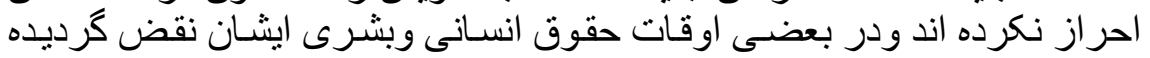

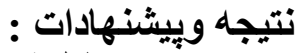

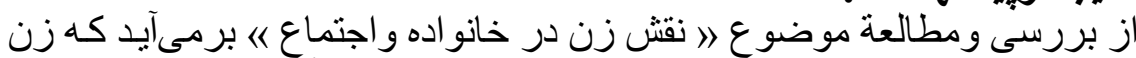

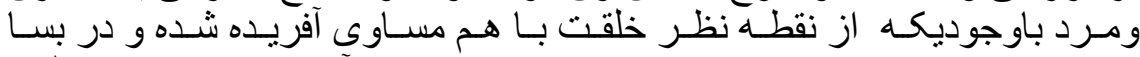

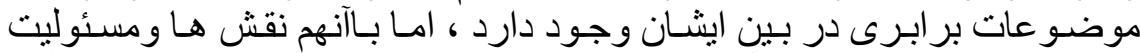

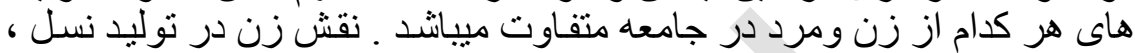

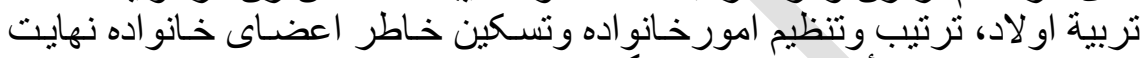

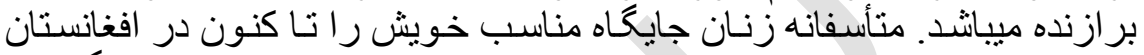

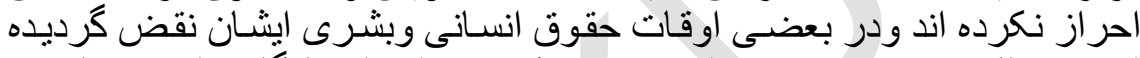

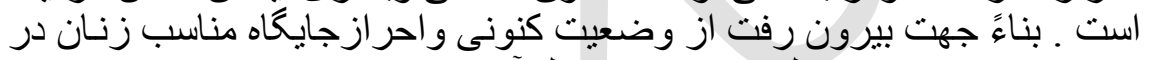

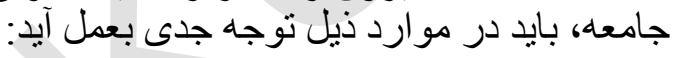

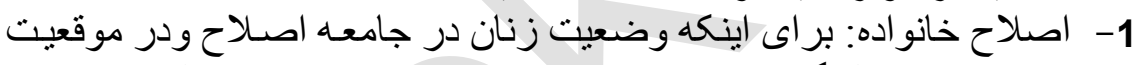

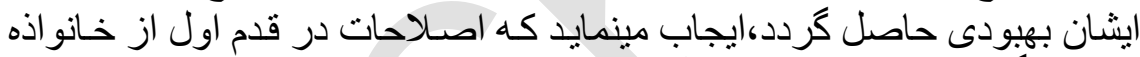

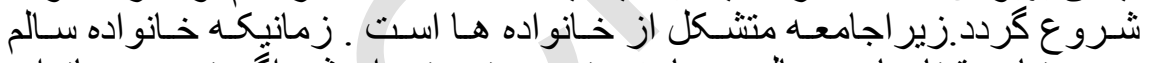

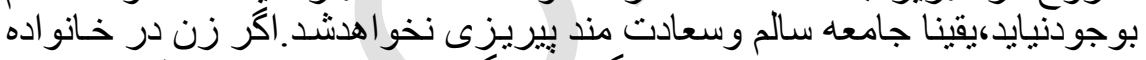

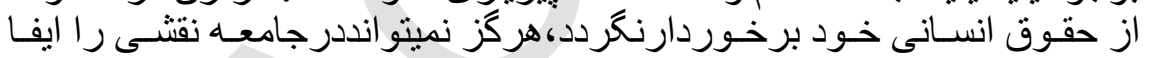

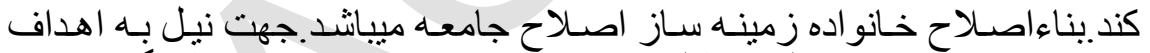

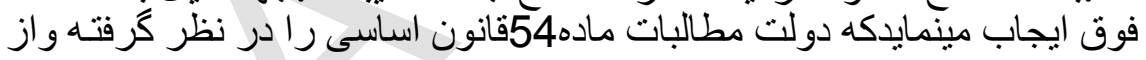

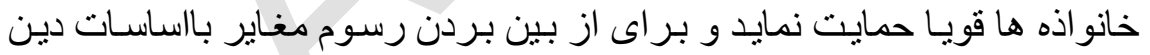

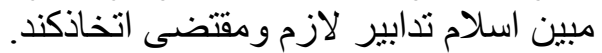

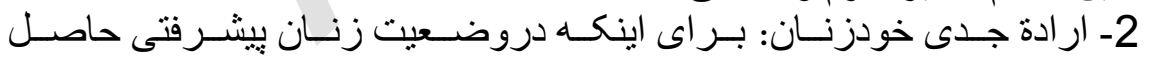

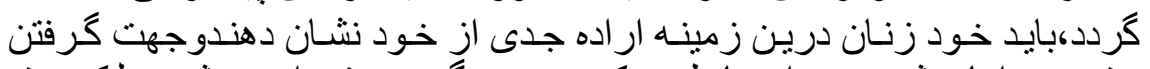

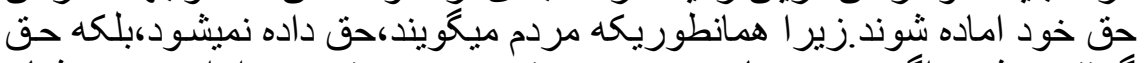

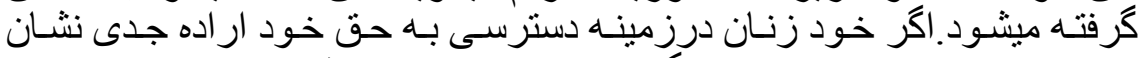

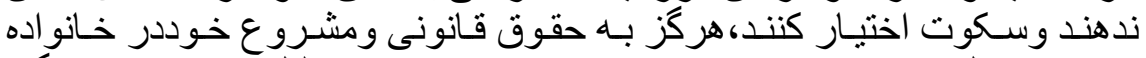

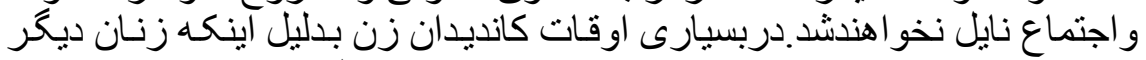

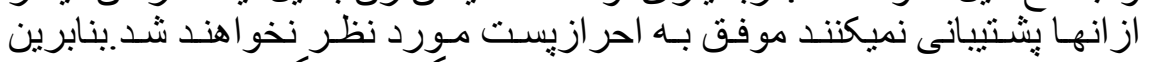

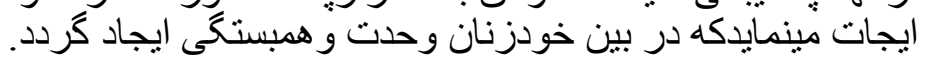




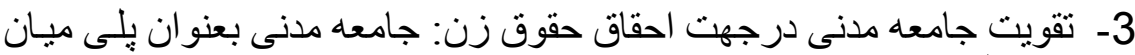

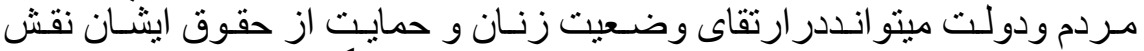

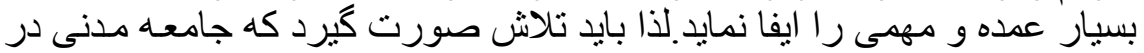

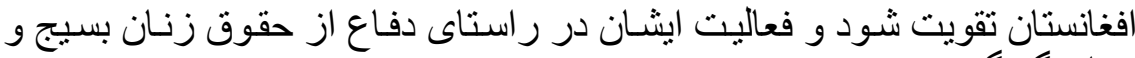

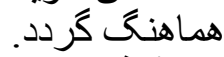
: مآخذ ومنابع

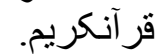

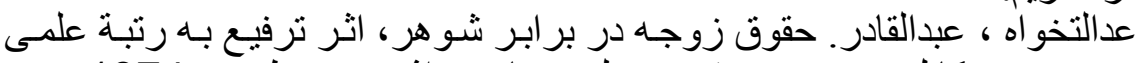

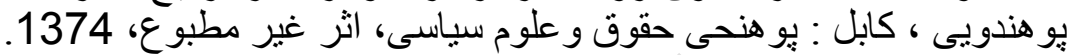

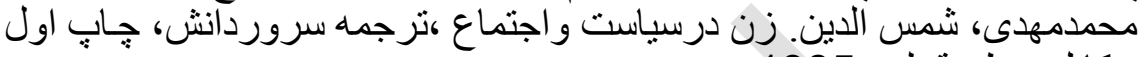

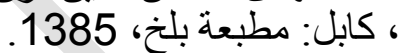

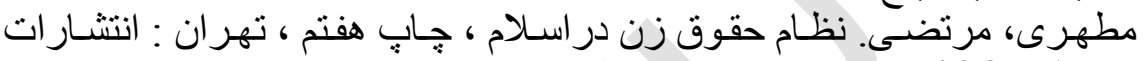

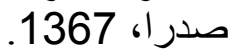

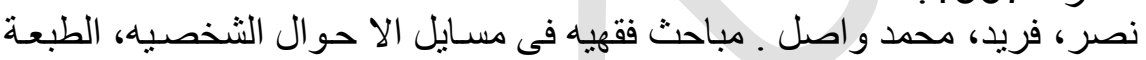

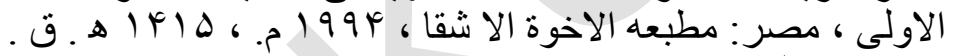

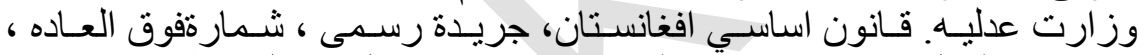

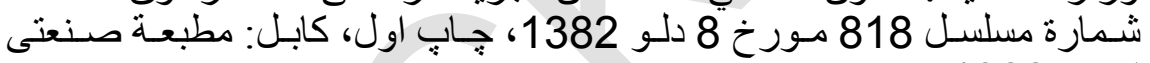

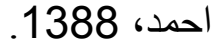

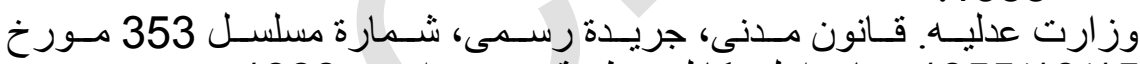

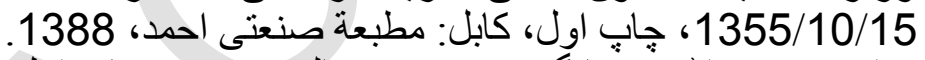

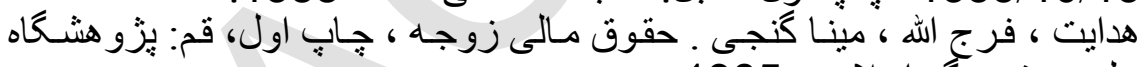

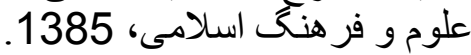

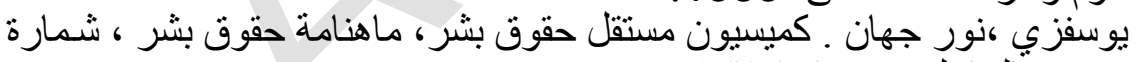

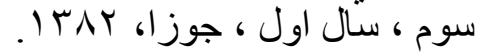




\section{مصادر مساوات در برابر قضناء قصل اون

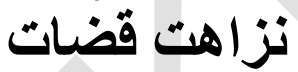

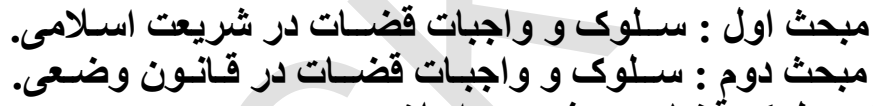

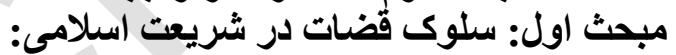

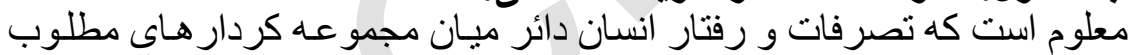

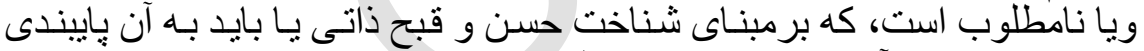

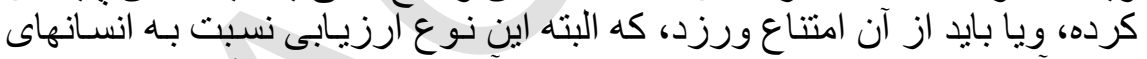

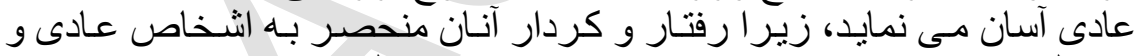

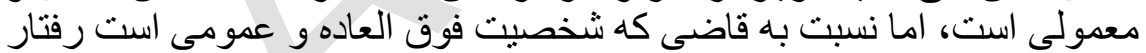

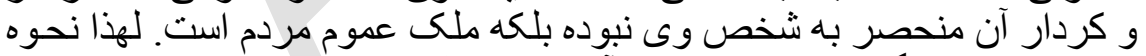

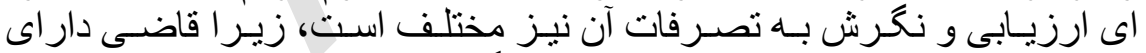

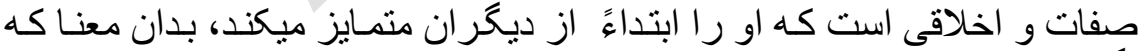

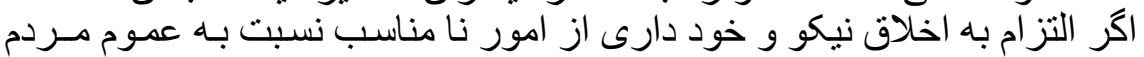

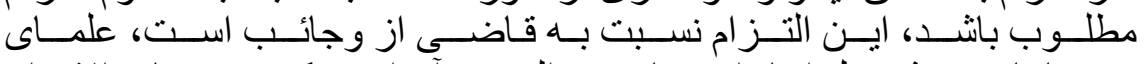

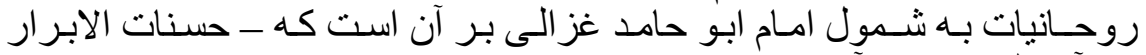

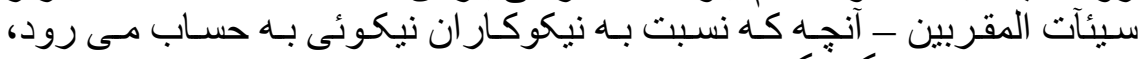
نسبت به جاه يافته كان كناه است الته

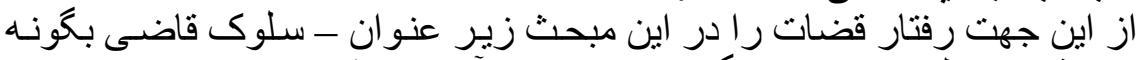

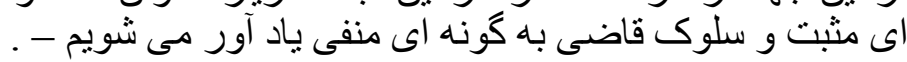




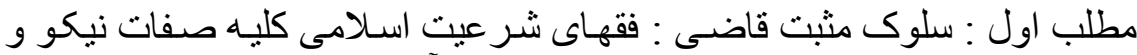

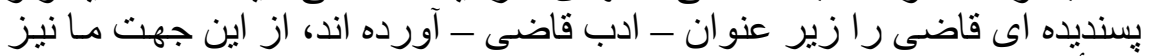

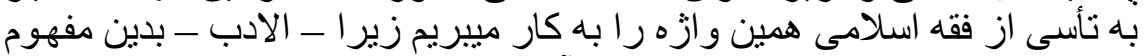

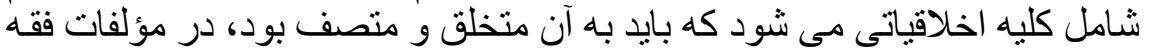

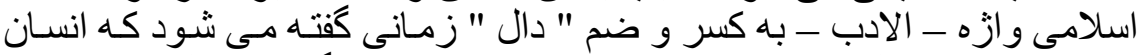

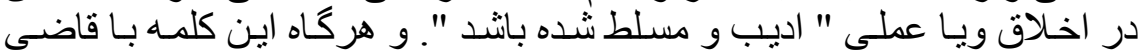

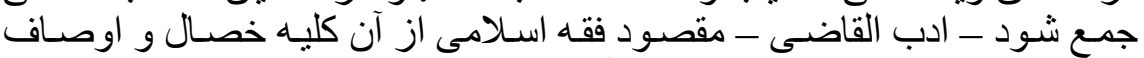

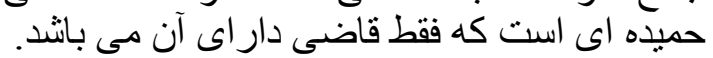

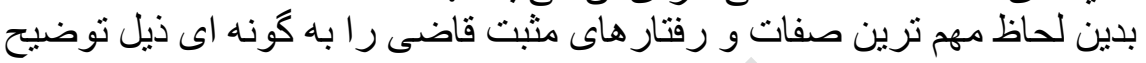

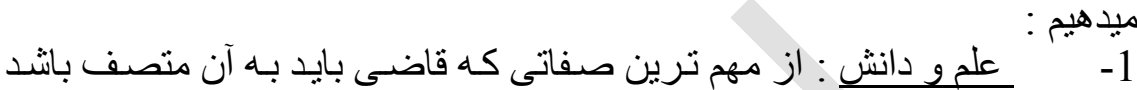

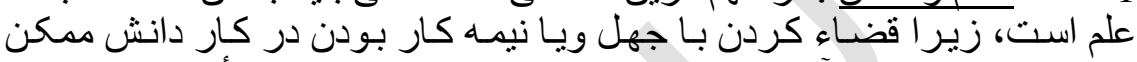

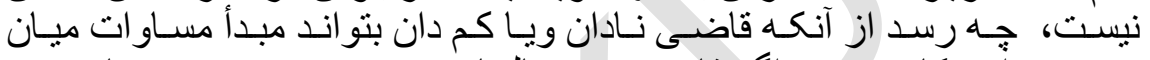

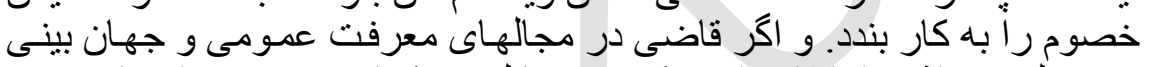

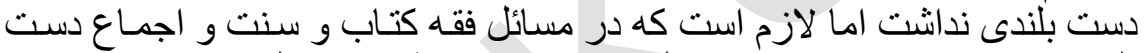

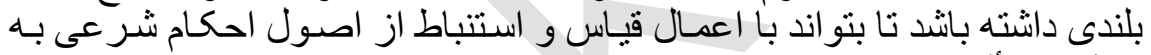

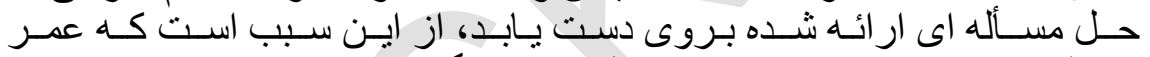

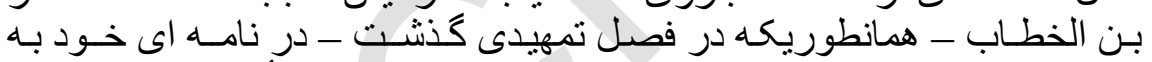

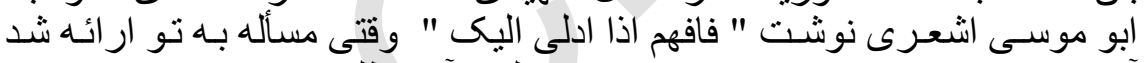

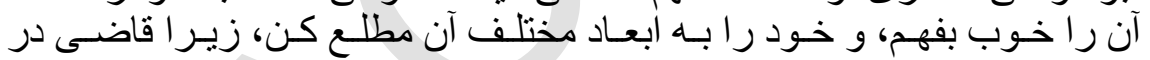

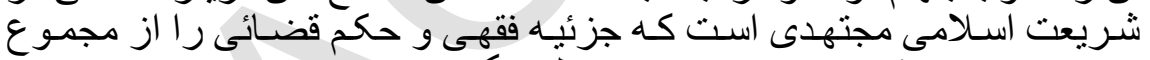

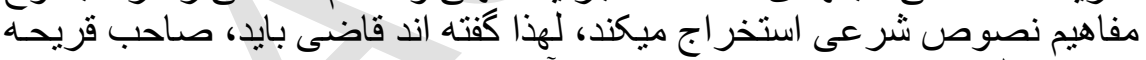

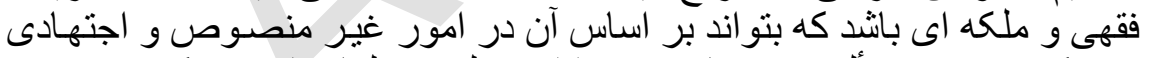

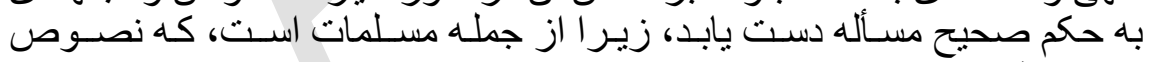

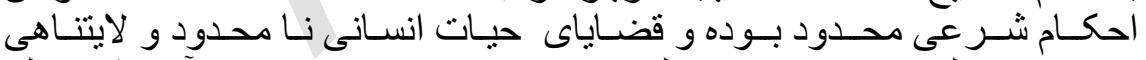

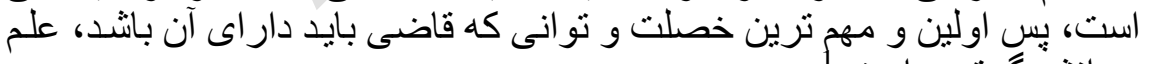
و دانش كسترده است.

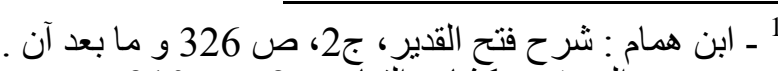

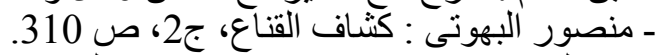

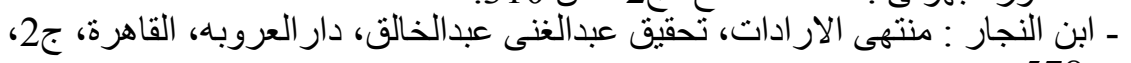

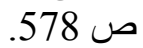
- الكاسانى : بدائع الصنائع : ج9، ص ص 4093 ـ 409 


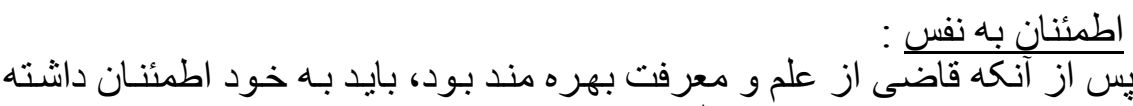

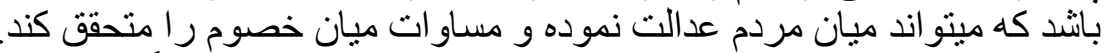

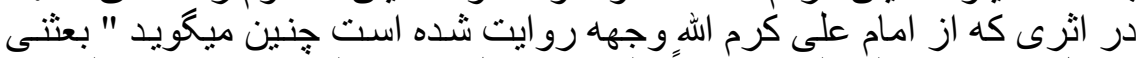

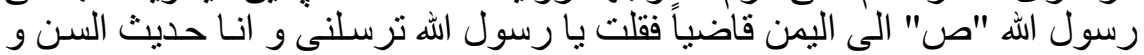

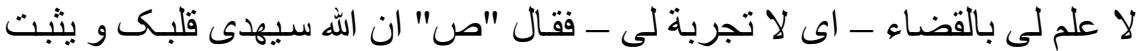

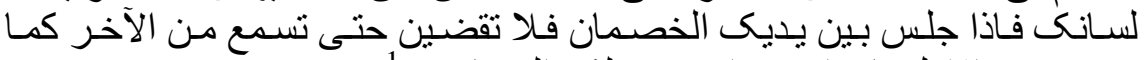

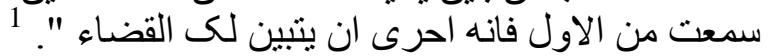

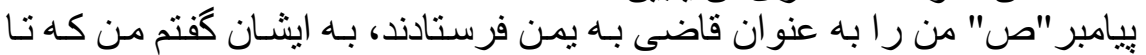

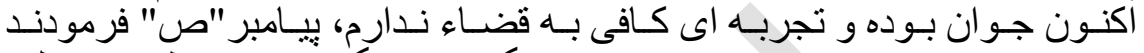

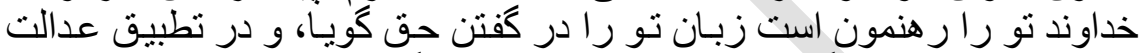

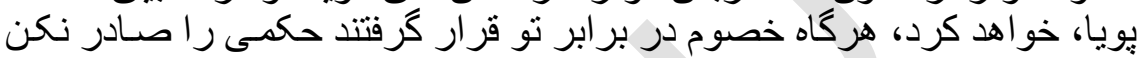

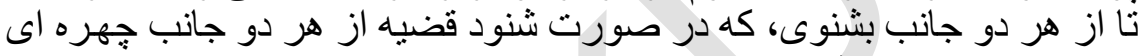

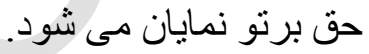

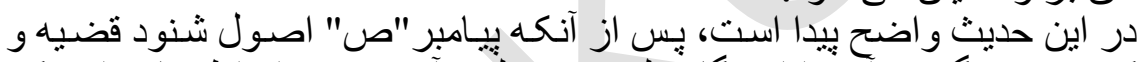

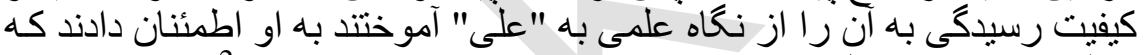

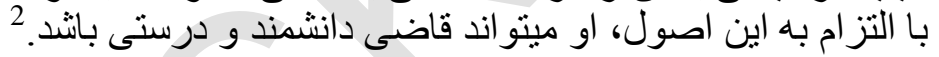

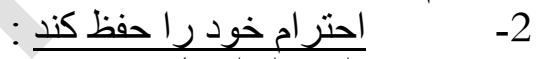

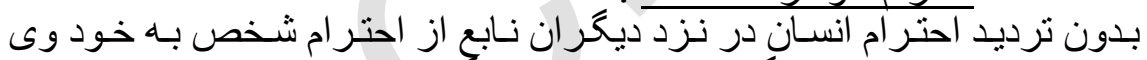

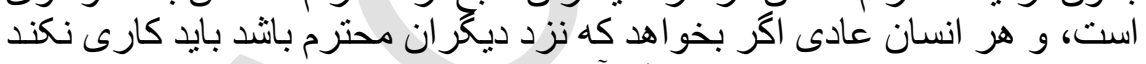

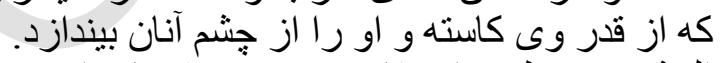

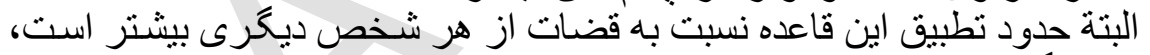

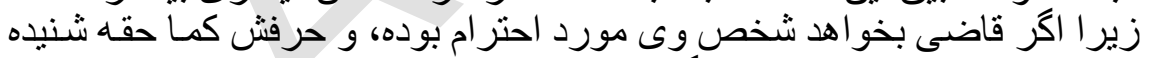

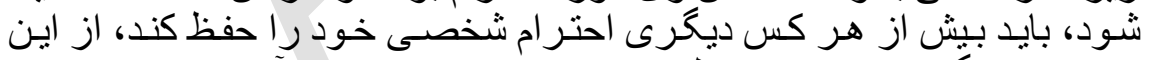

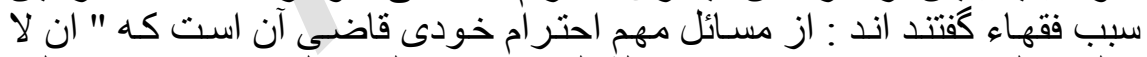

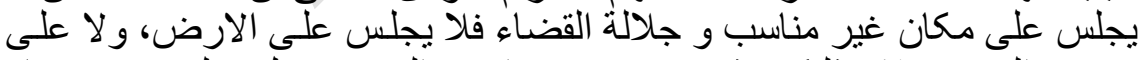

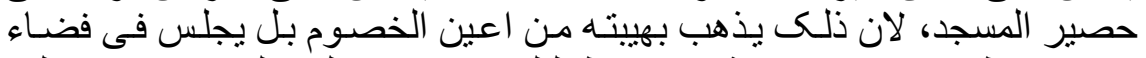

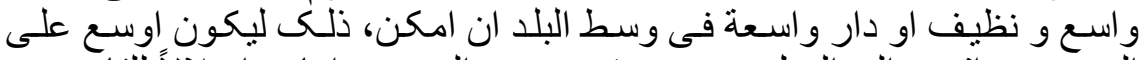

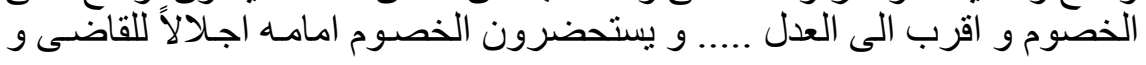

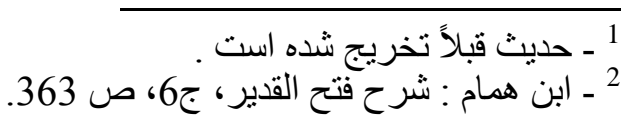




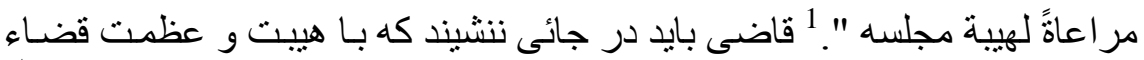

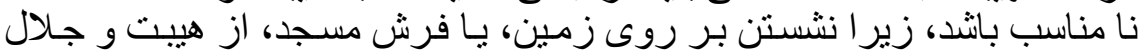

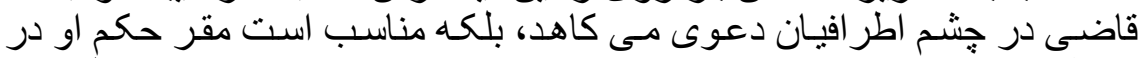

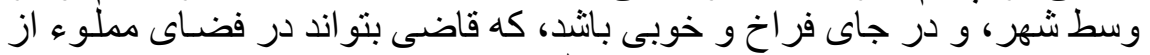

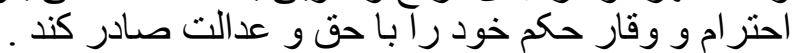

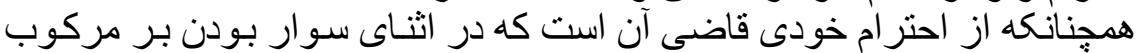

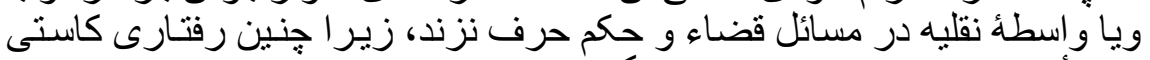

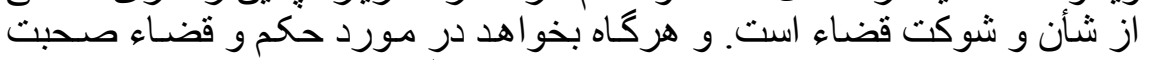

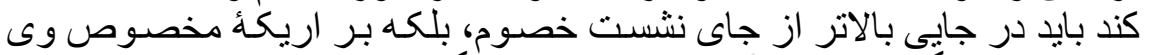

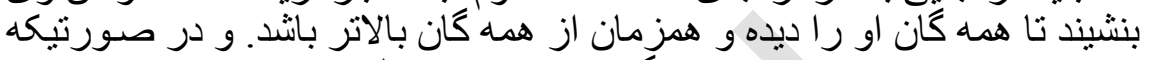

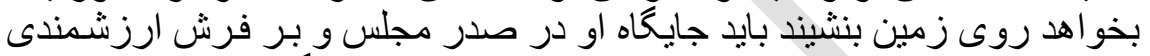

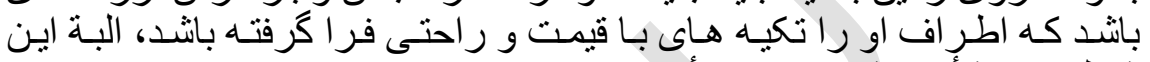

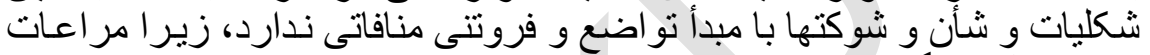

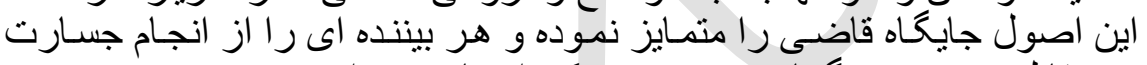

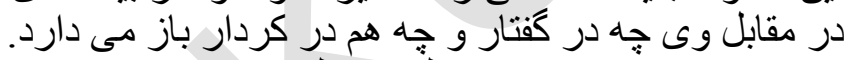

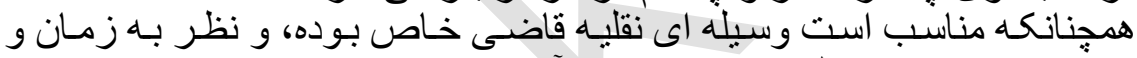

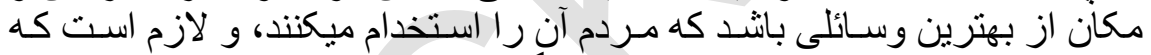

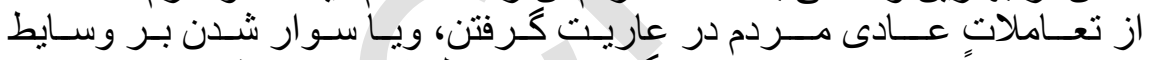

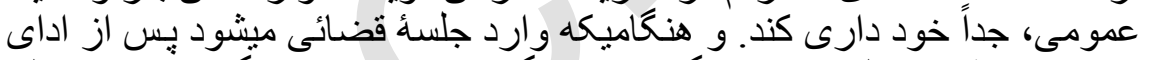

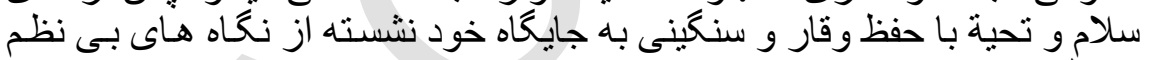

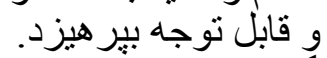

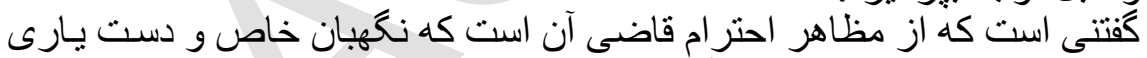

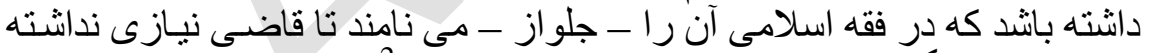

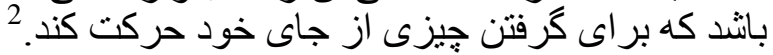

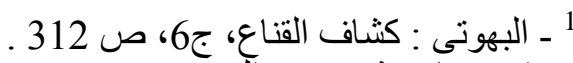

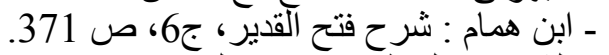

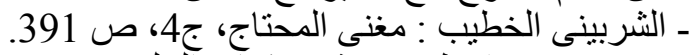

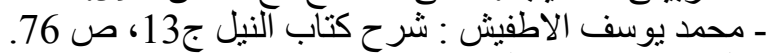

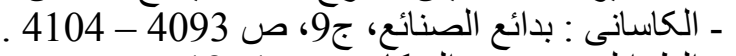

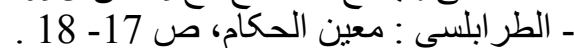

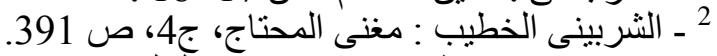

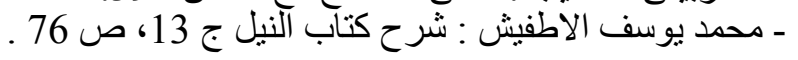




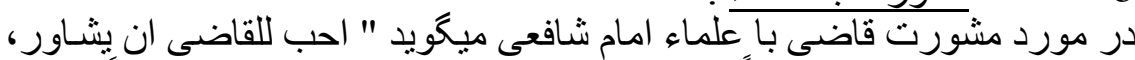

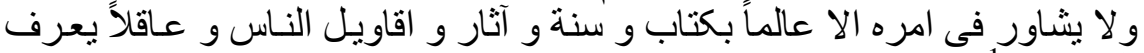

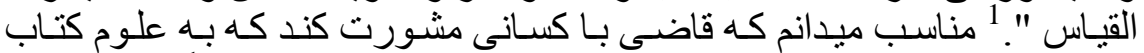

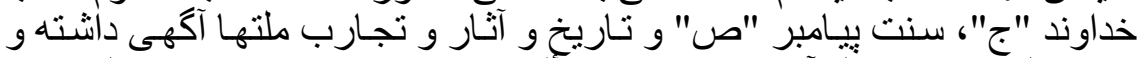

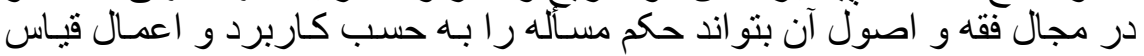

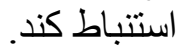

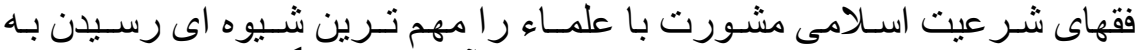

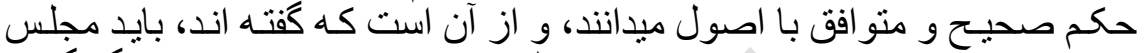

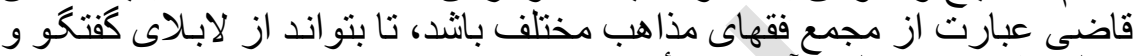

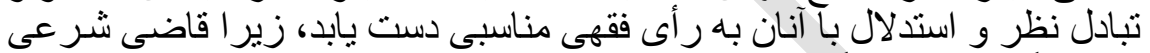

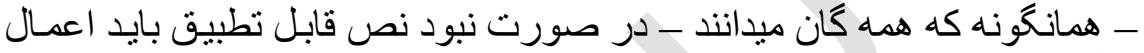

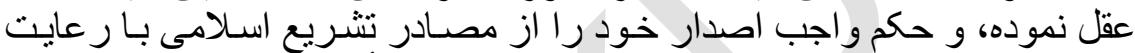

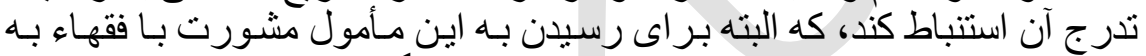

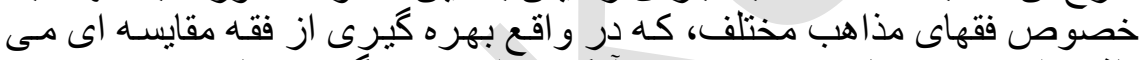

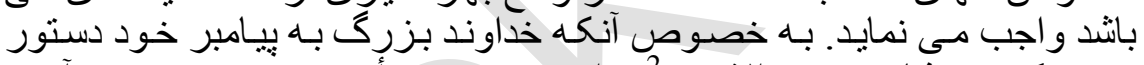

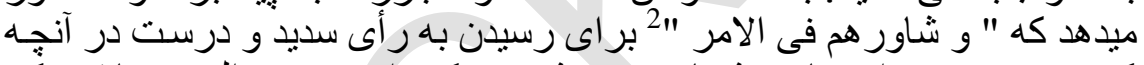

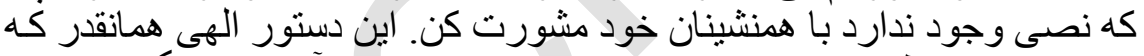

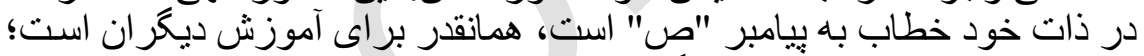

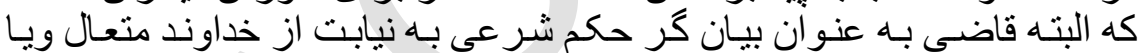

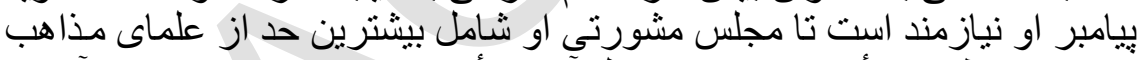

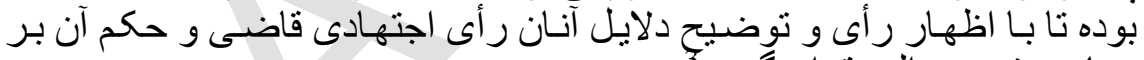

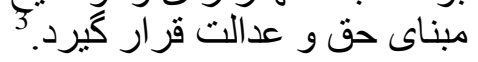

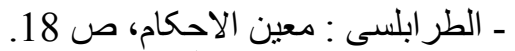

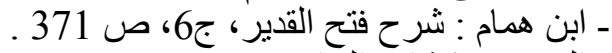

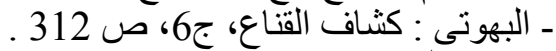

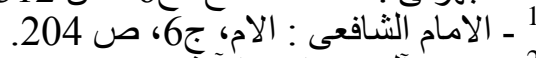
2 ـ سورة آل عمران ، الآية : 259.

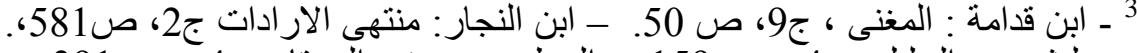

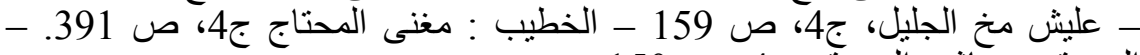

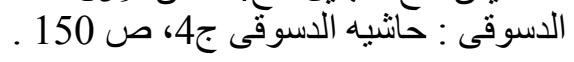




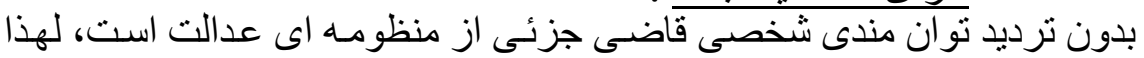

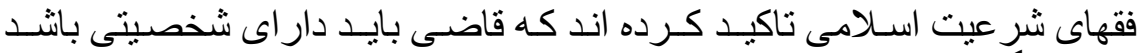

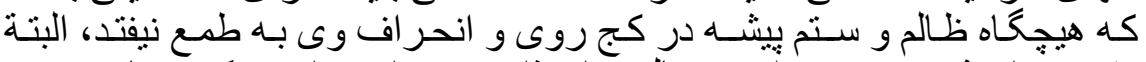

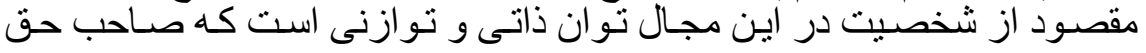

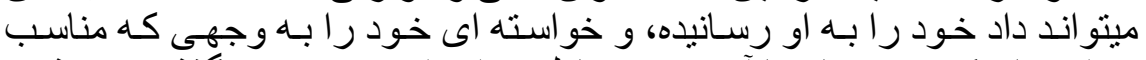

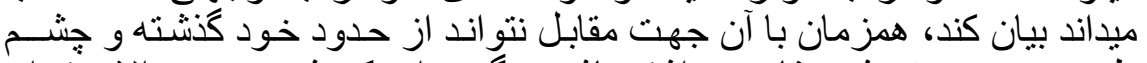

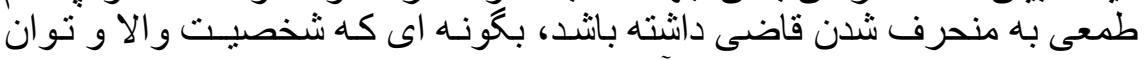

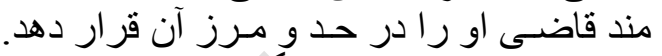

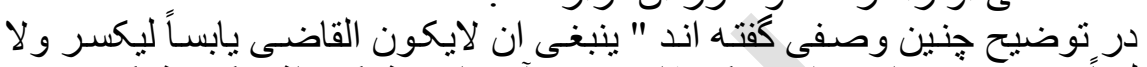

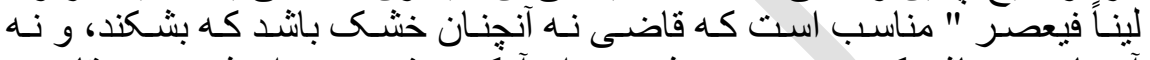

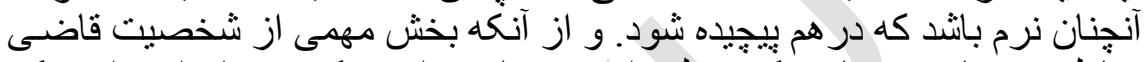

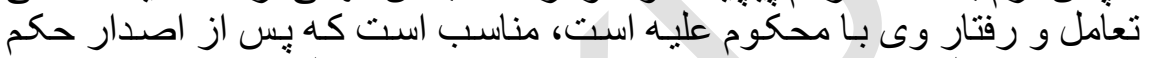

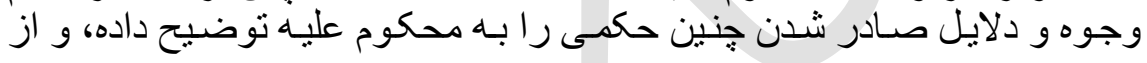

در المغنى آورده است كه: روزى كعب بن سو ار به مجلس عمر بن الخطاب نشسته بود

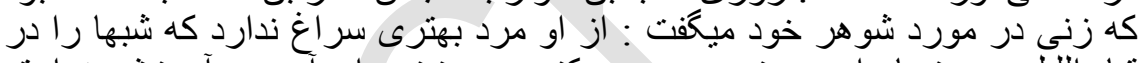

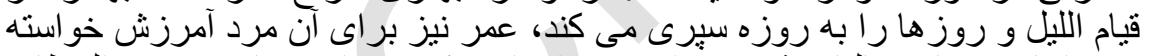

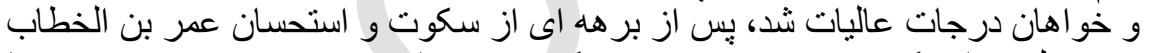

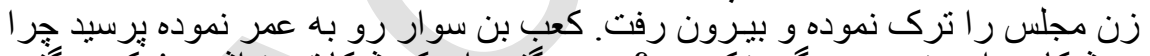

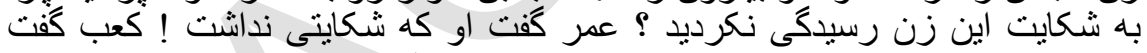

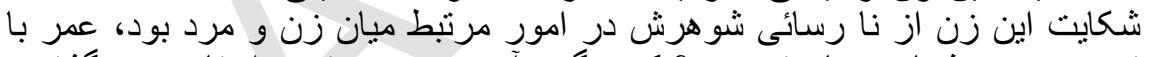

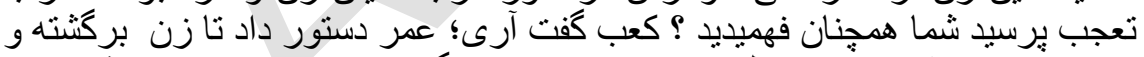

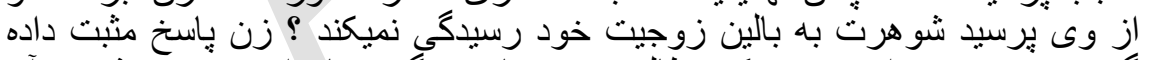

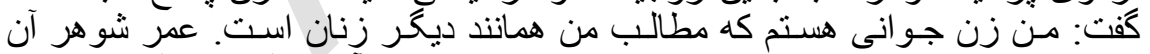

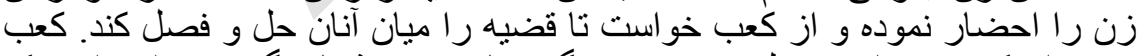

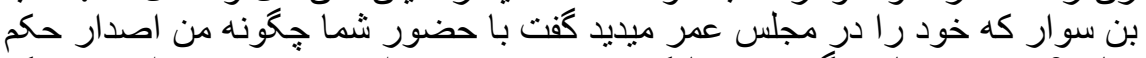

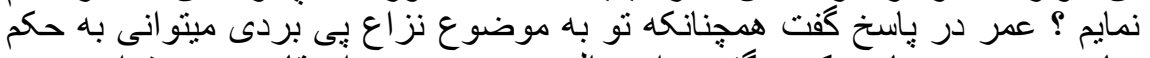

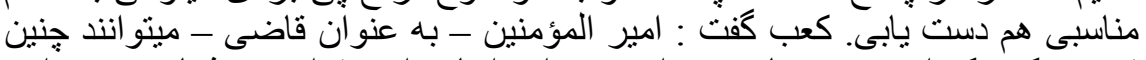

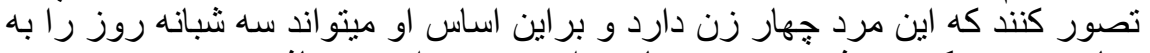

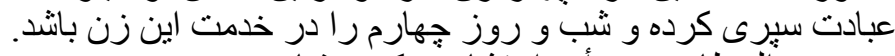

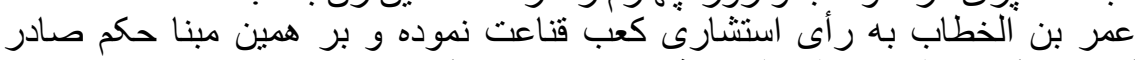

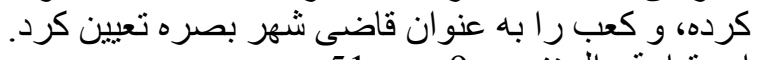
ابن قدامة : المغنى، جون، صنوان صاضى 51. 


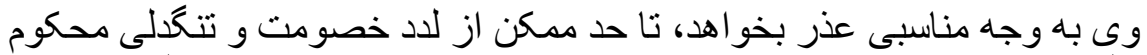

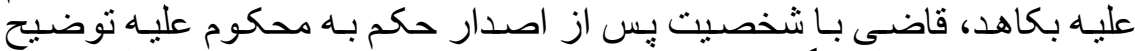

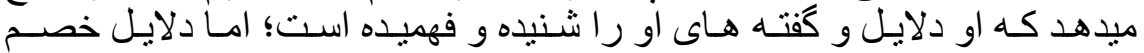

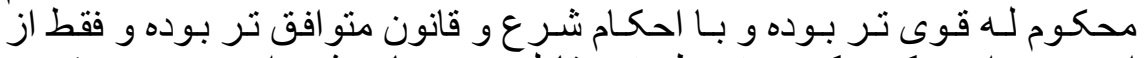

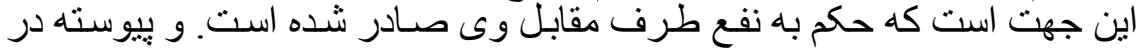

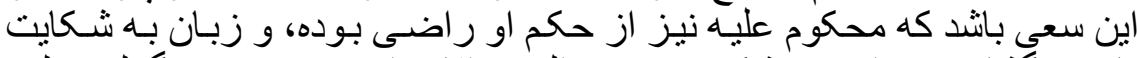

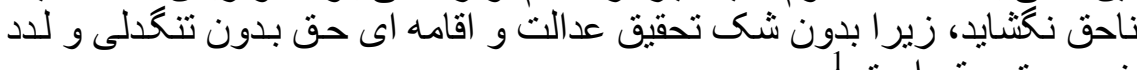

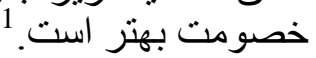

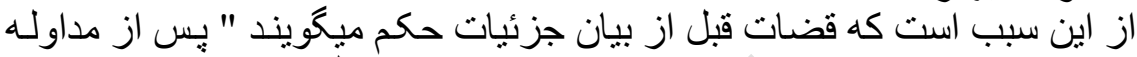

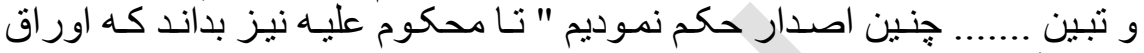

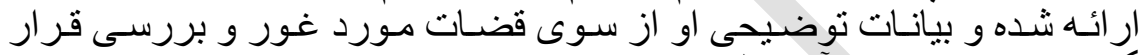

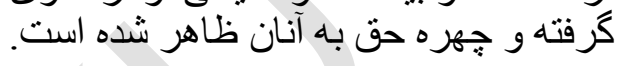

\section{انتخاب هم نشينان :}

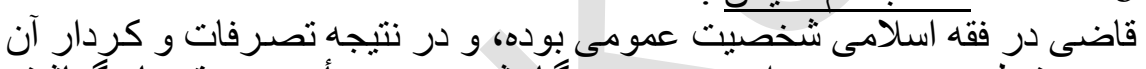

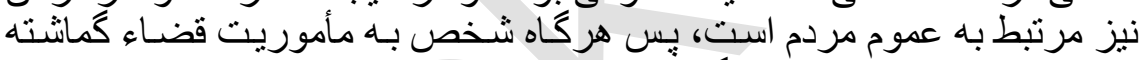

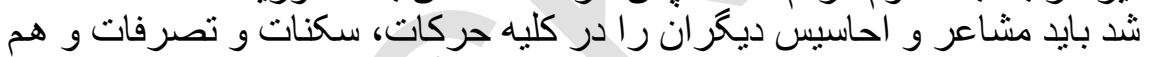

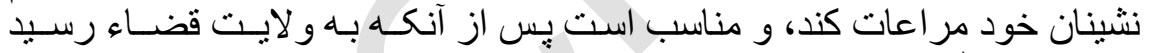

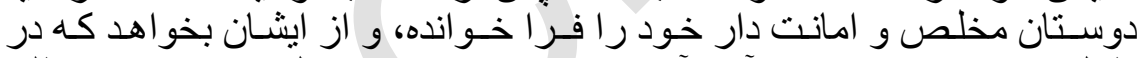

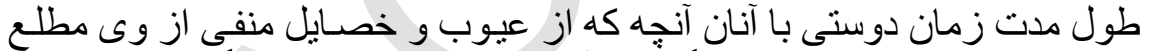

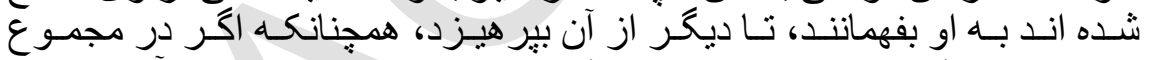

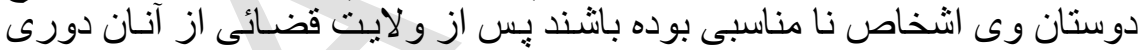
كند.

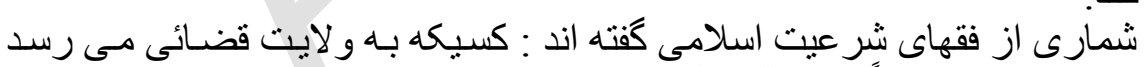

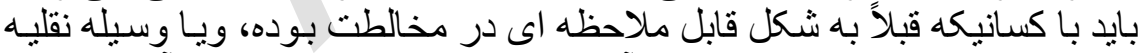

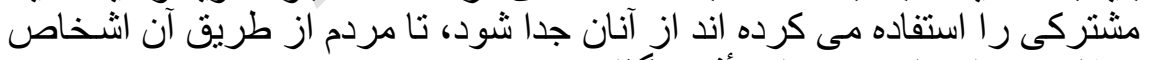

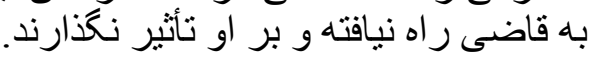

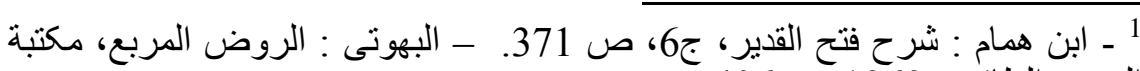

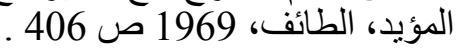




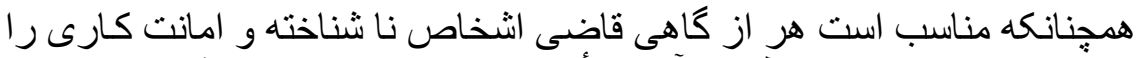

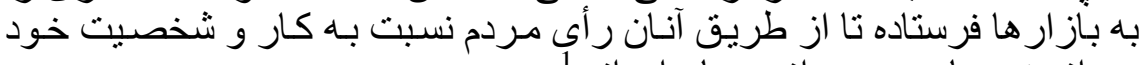

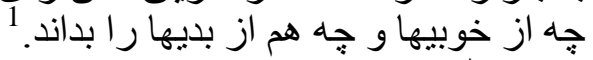
7 - محل كار مناسب :

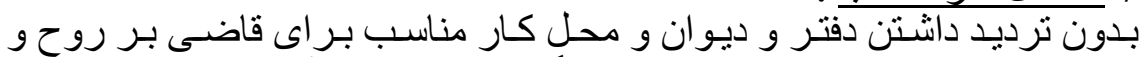

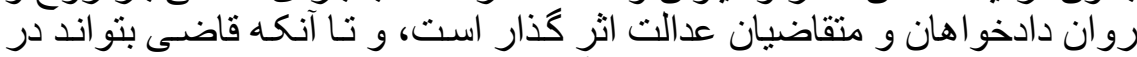

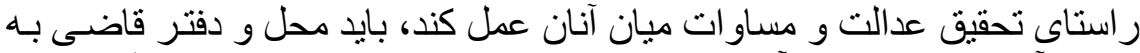

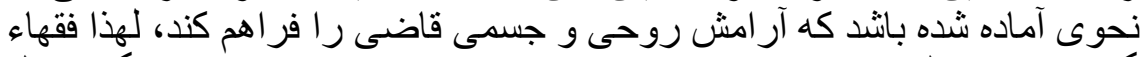

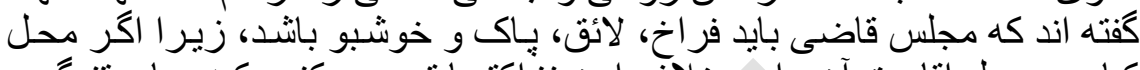

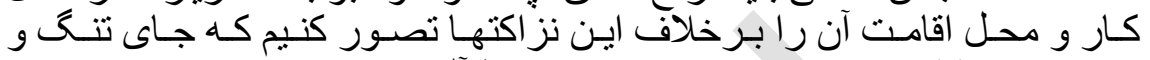

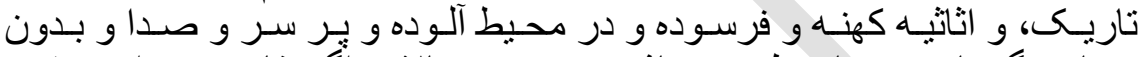

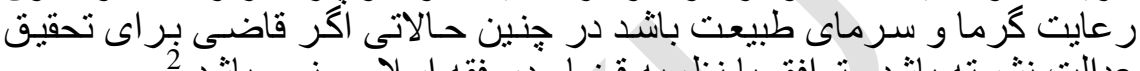

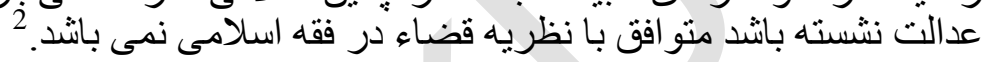

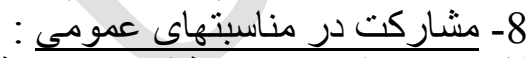

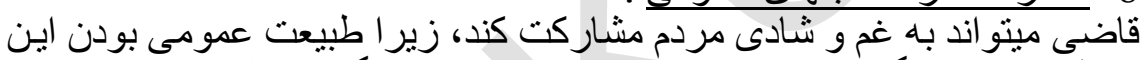

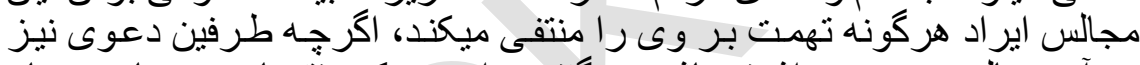

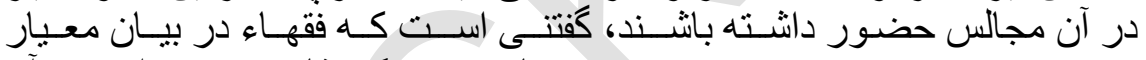

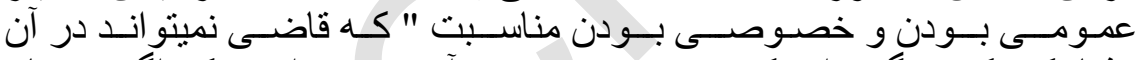

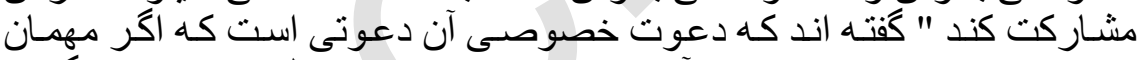

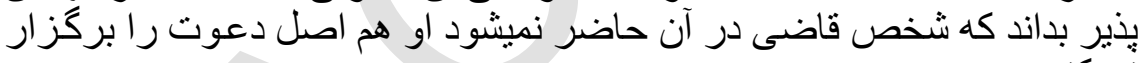
نميكند.

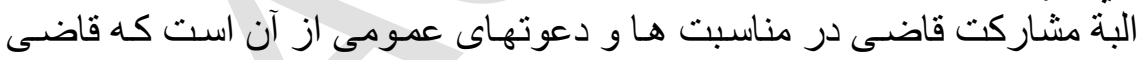

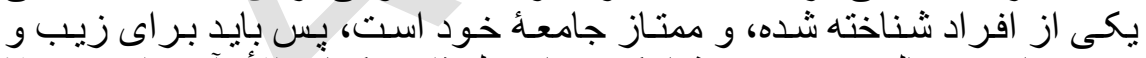

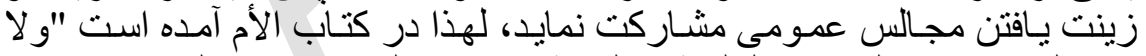

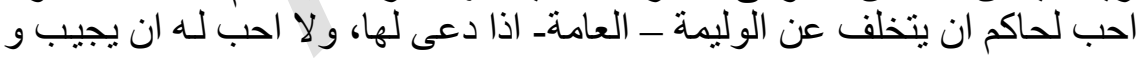

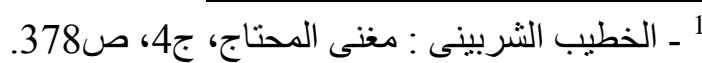

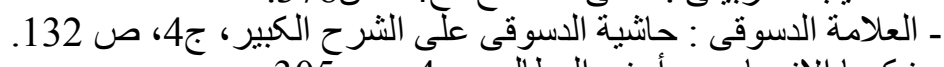

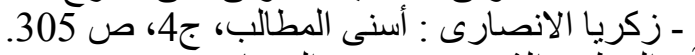

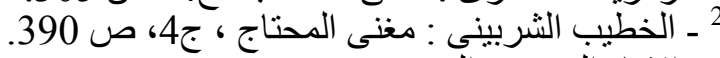

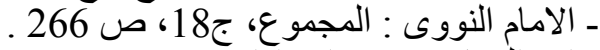

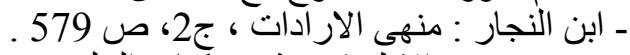

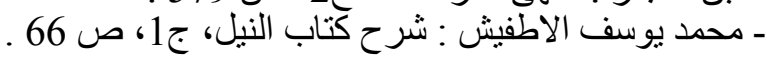




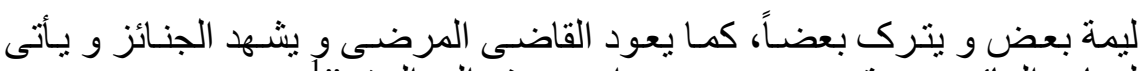

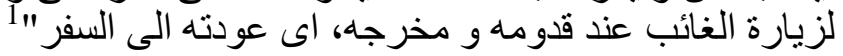

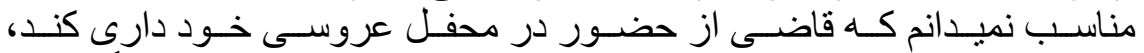

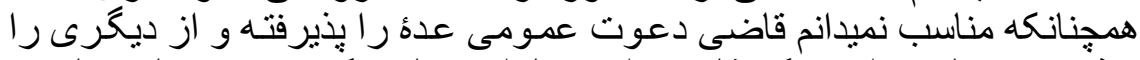

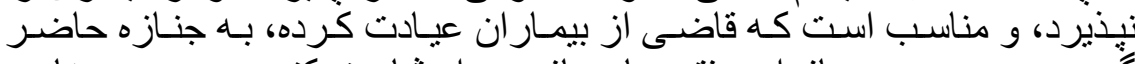

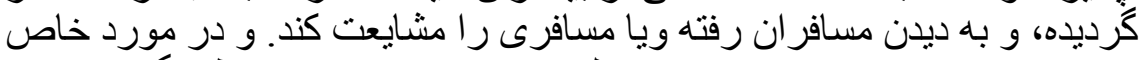

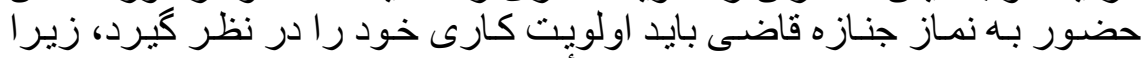

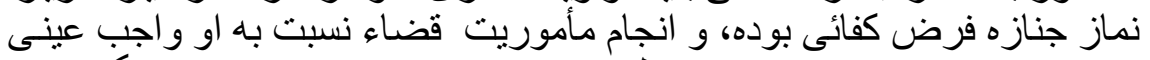

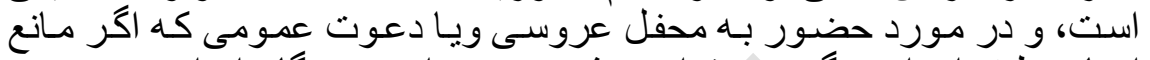

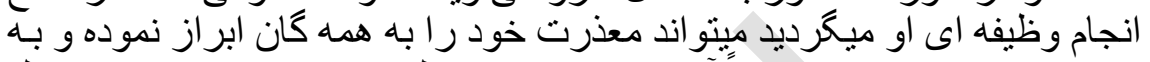

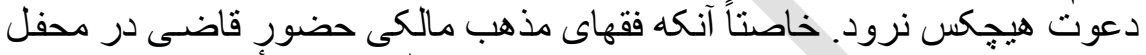

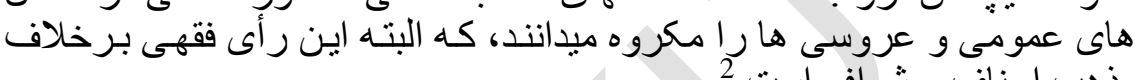
مذهب احناف و شوى شرو افع است.

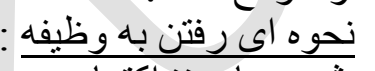

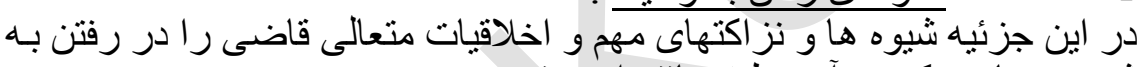

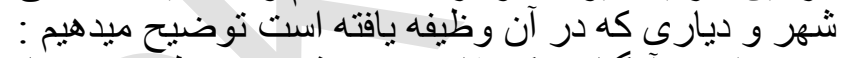

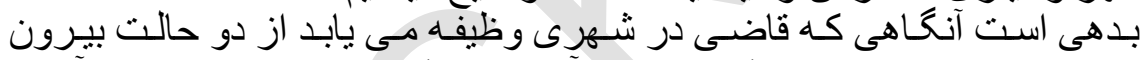

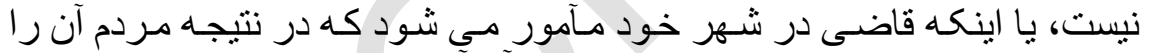

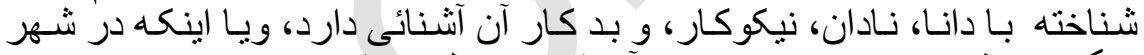

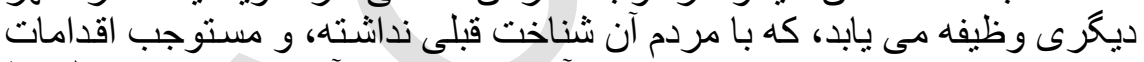

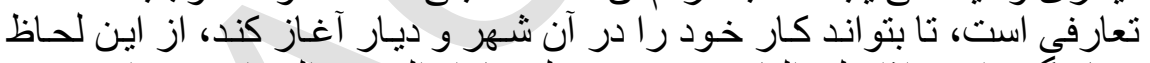

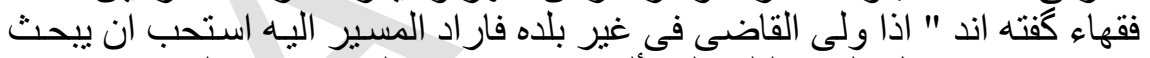

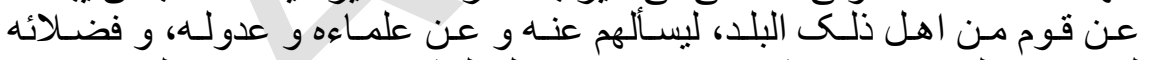

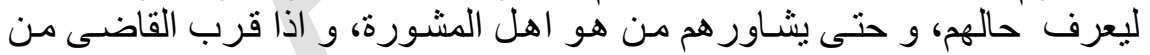

1 ـ الامام الثافعى : الام، ج6، صك 204.

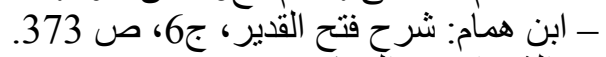

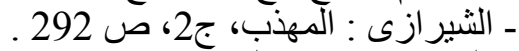

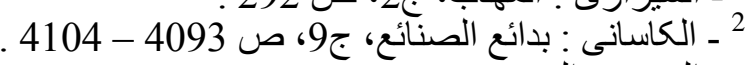

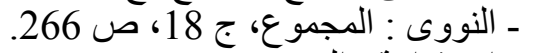

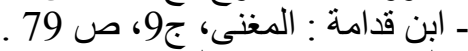

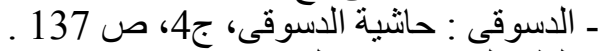

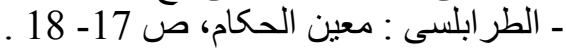




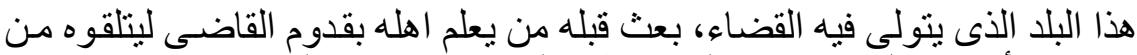

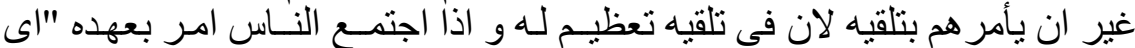

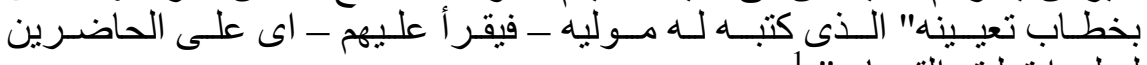

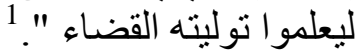

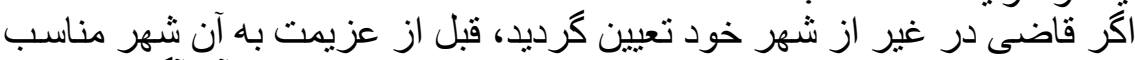

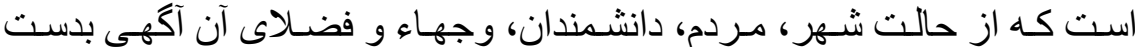

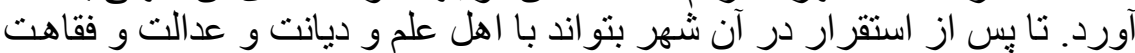

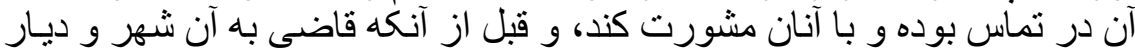

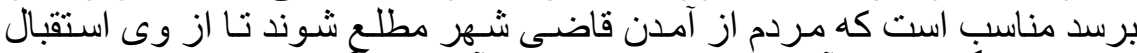

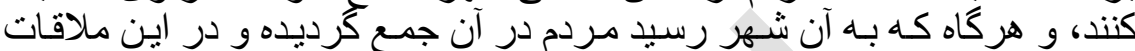

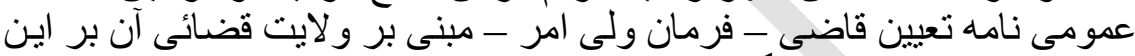

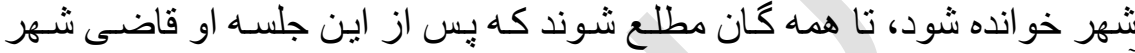

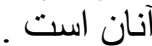

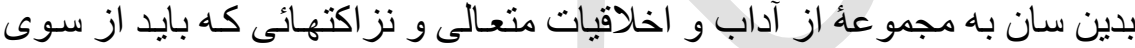

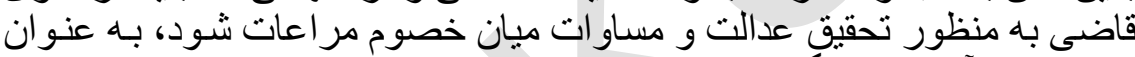

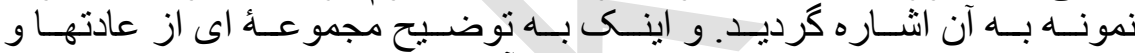

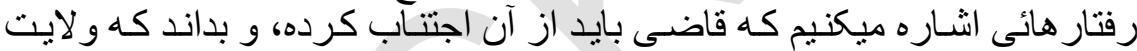

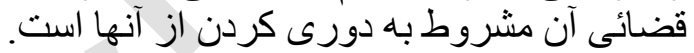

1 ـ البهوتى : كثاف القناع، ج6، ص 311. 311. - الشربينى : مغنى المحتاج، ج4، ص

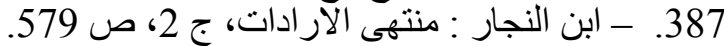

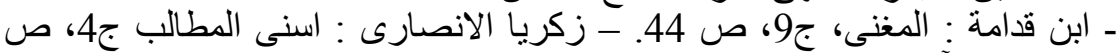
392 و ما بعد آن . 
بيوست بـ كذنته

تتبع ونـارش: محمد ناصر " حسن زاده "

\title{
سير تحول قضاعومشروطيت درافغانستان
}

\author{
مبحث بـانزدهم \\ تشكيلات محاكم دوره (مانيه
}

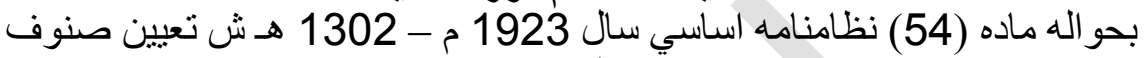

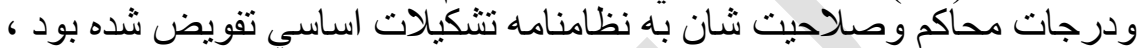

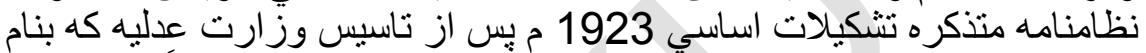

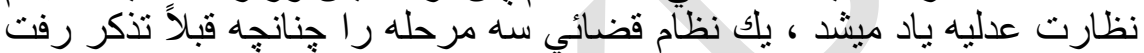

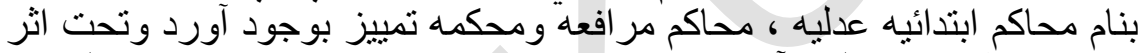

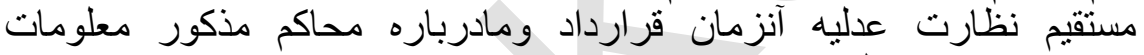
مختصري بقرار ذيل ار ائه مينمائيم : مانيه الف :- محكمه ابتدائيه عدليه :

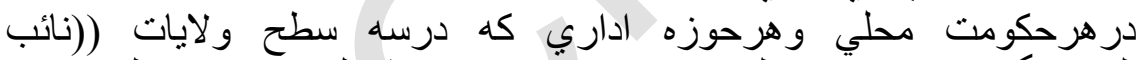

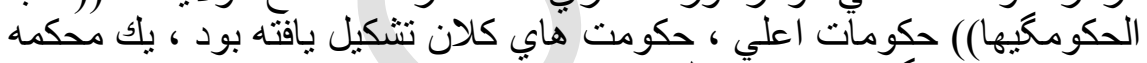

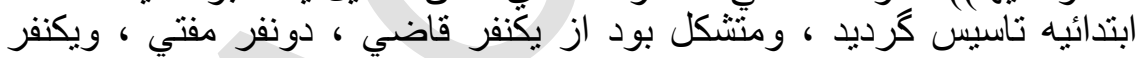

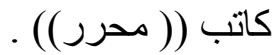

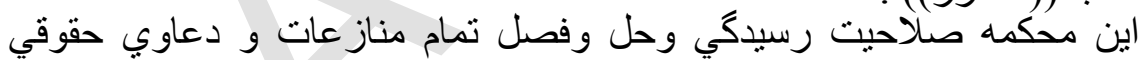

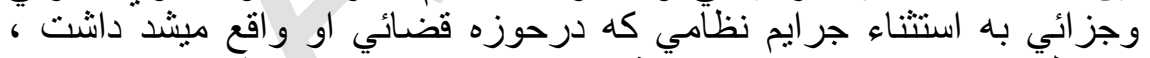

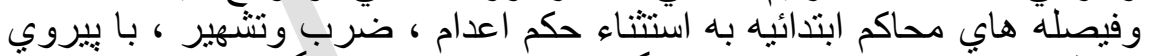

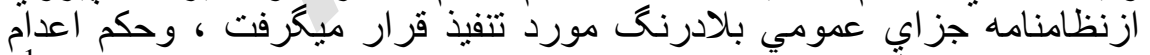

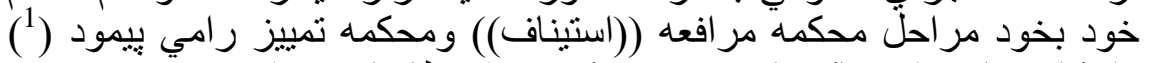

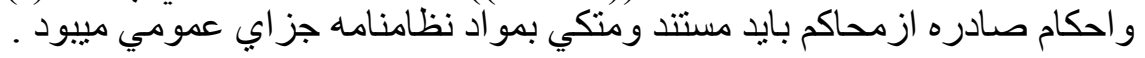

1 يس اين ادعاي آقابي سيد مهدي فرخ مندرج درجلد اول كتاب تاريخ سياسي افغانستان

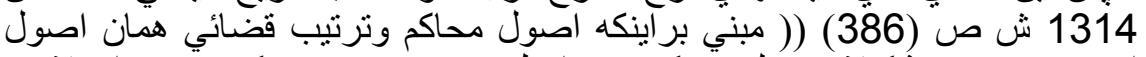

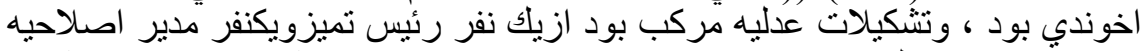

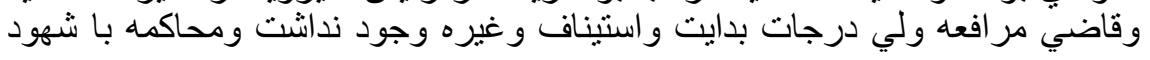


به اساس حكم ماده (53) نظامنامه اساسي هيج مرجعي حق مداخ مداخله درامور

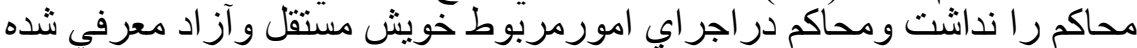

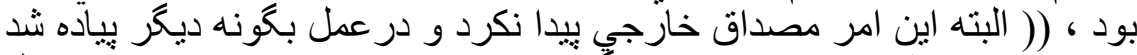

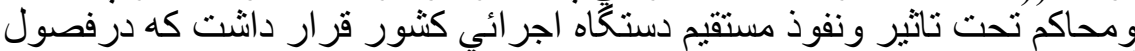

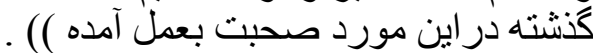

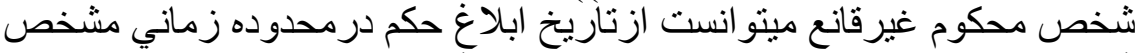

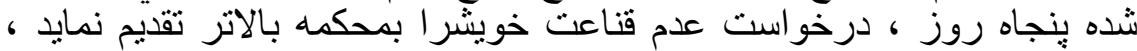

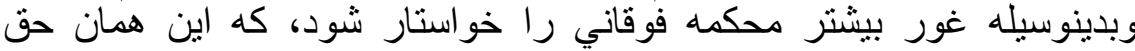

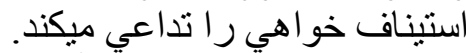

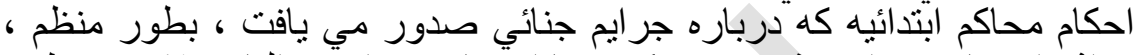

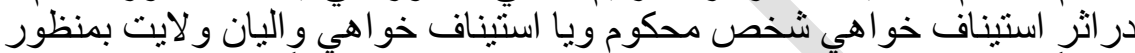

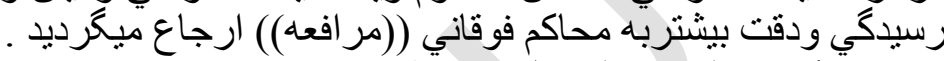

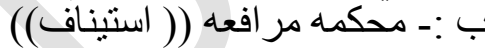

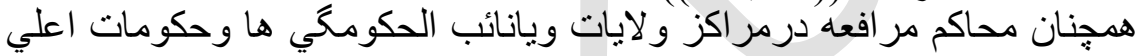

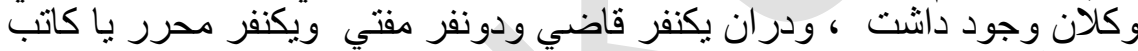

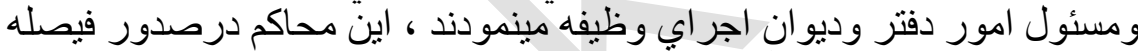

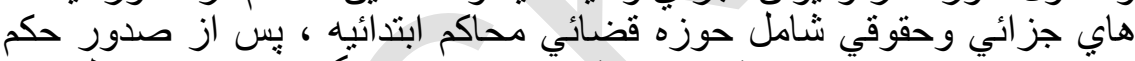

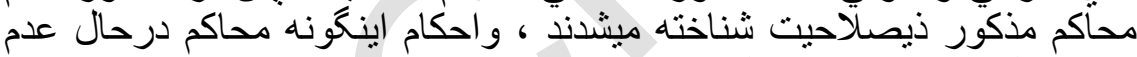

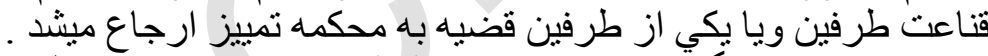

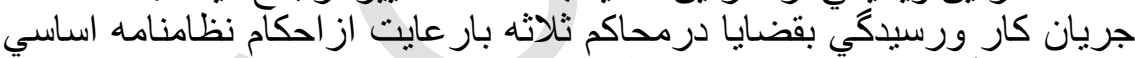

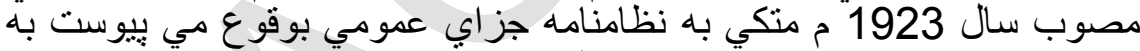

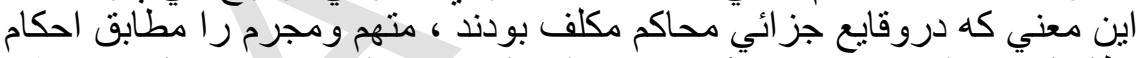

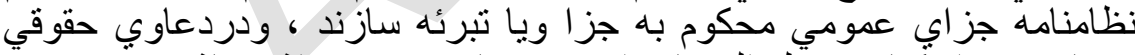

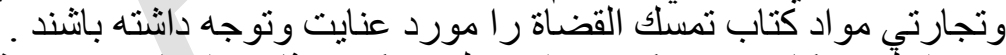

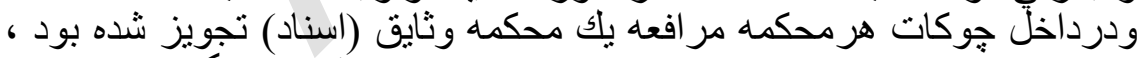

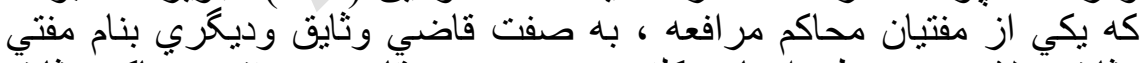

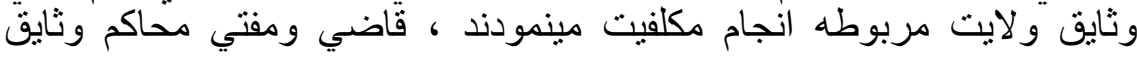

رتق وفتق ميشد )) بموجب مطالب وتفصيلاتيكه درباب محاكم ونظامنامه هاي دوره

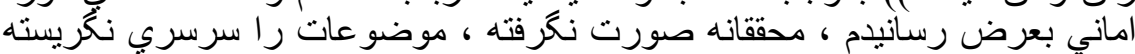

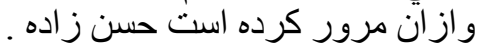


در عين حال راجع بمسائيلكه بمحكمه مر افعه وارد ميكرديد دربعد استينافي آن

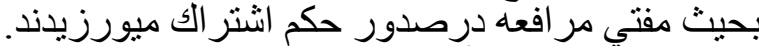

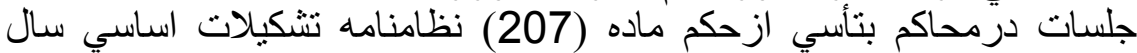
1302 هـ ش وماده (50) نظامنامه اساسي سال (207) نظمادي 1302 هـ ش بطور علني انعقاد مي يافت . مكر بعضي قضانيائيكه نظامنامه مخصوصه به خفيه دايرشدن جلسات آن امر

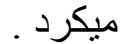

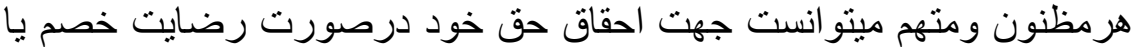

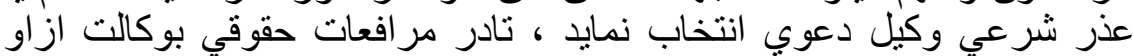

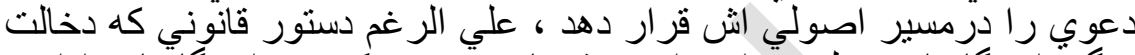

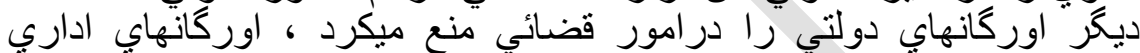

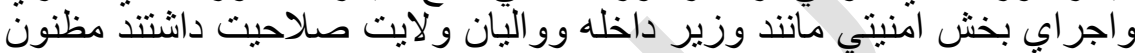

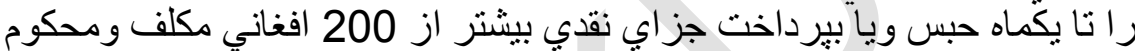

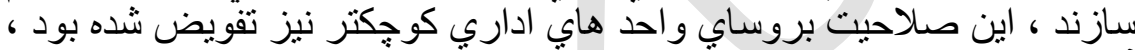

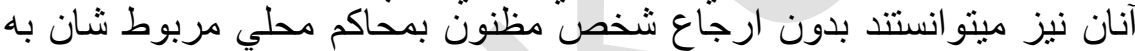

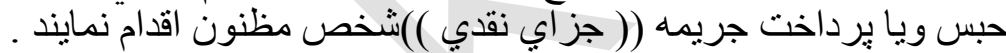

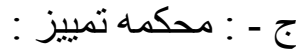
اين محكمه ر را در ابعاد ذيل مينو ان مطالعه وبررسي كرد :

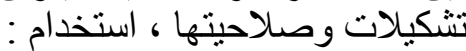

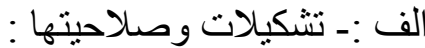

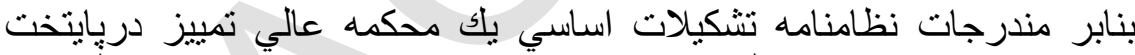

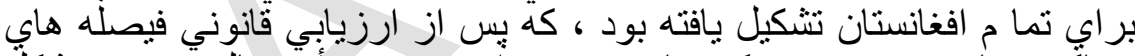

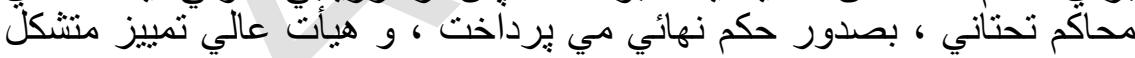

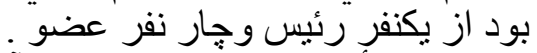

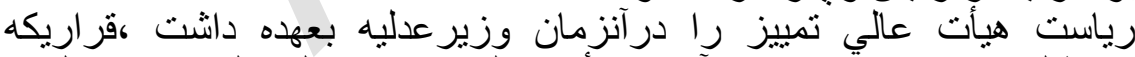

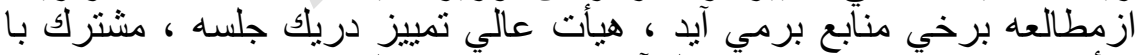

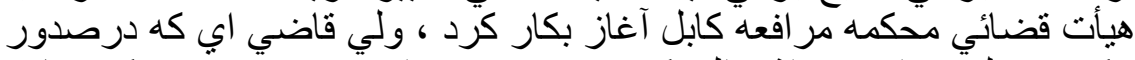

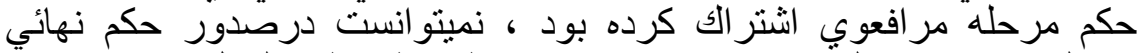

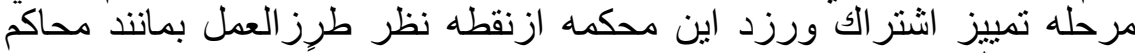

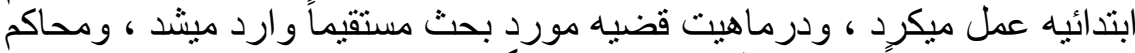

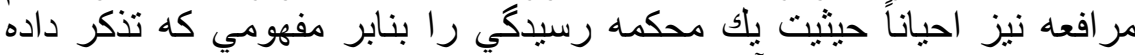

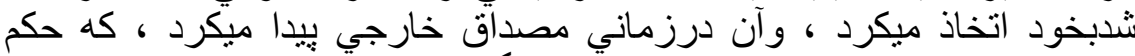
محكمه ابتدائيه را نقض ودعوي رآن درزي درييشخاه خود بمأنند محاكم ابتدائيه تحت 


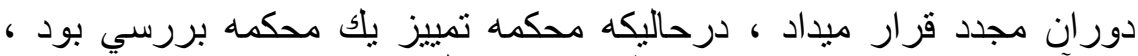

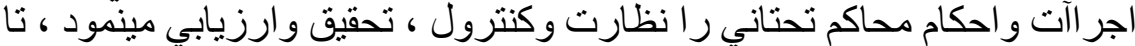

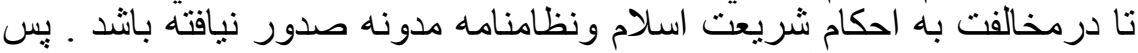

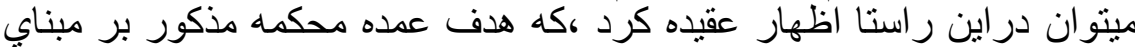

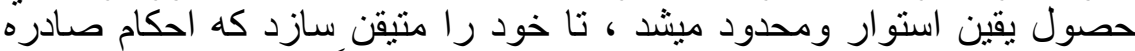

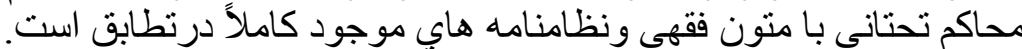

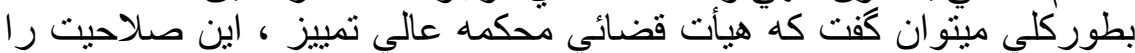

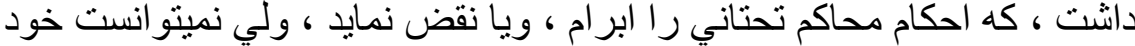

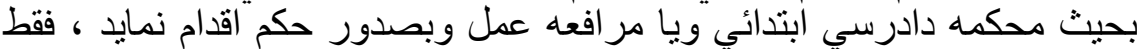

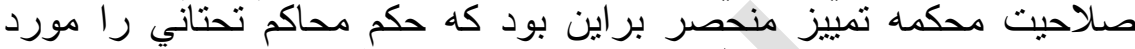

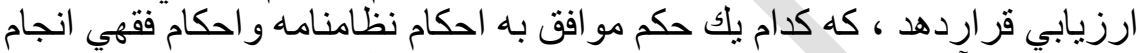

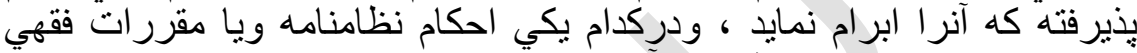

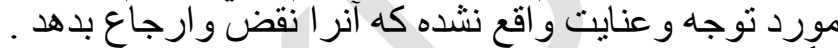

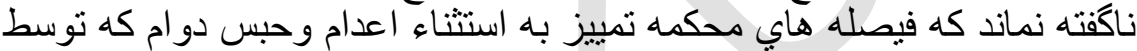

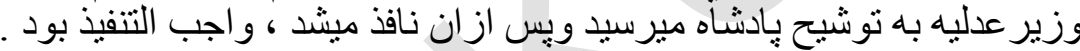

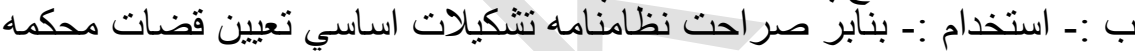

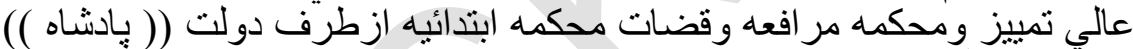

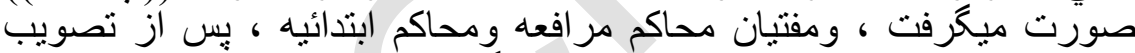

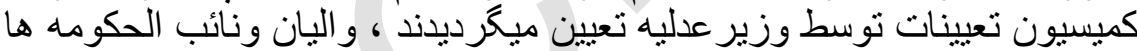
صلاحيت تقرر و استخدام مفتيان محاكم ابتدائيه وكاتبان محاكم مرئن مر افعه ومحاكم

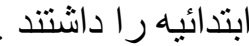

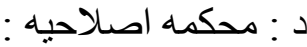

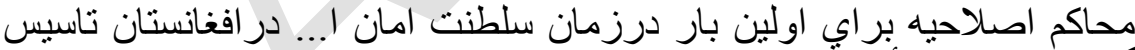

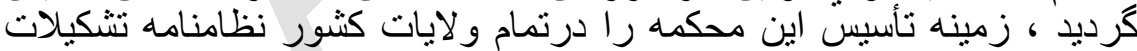

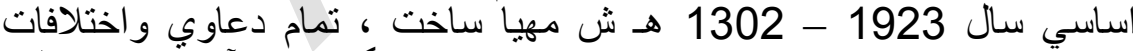

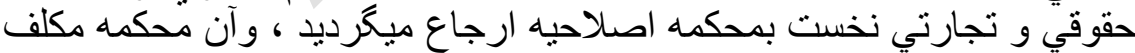

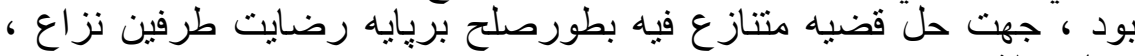

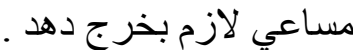

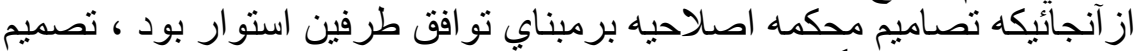

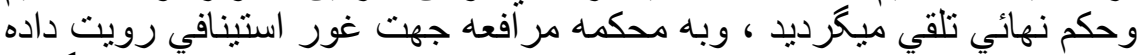

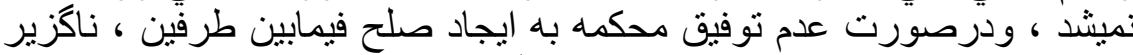

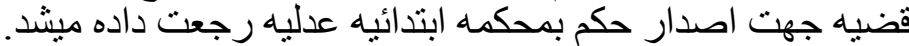


طرفين دعوي ، در اصدار تصاميم محكمه اصلاحيه نقش ارزنده داشتند ، وبدون

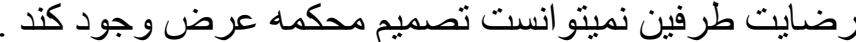

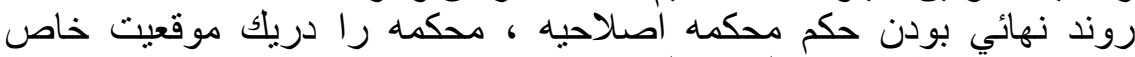
قر ارميداد ، مظهر استقلال وشكل دهنده قدرت محكمه مذكور را توجيه ميكرد

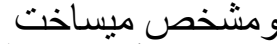
بيش از تأسيس اينكونه محاكم حل وفصل قضاياي مدني مربوط حوزه قضائي

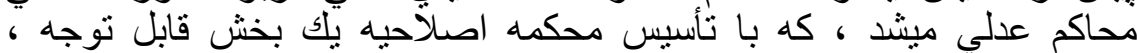

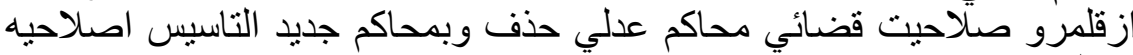

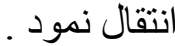

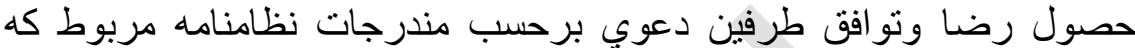

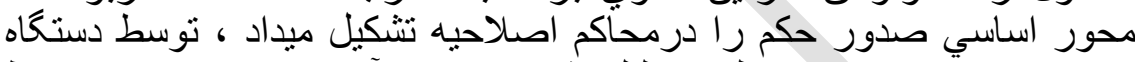

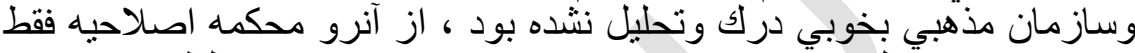

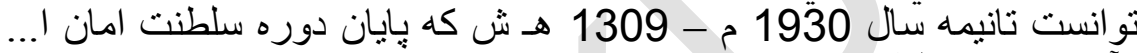

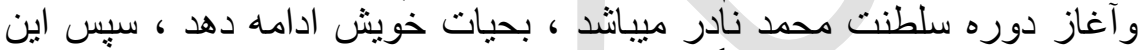

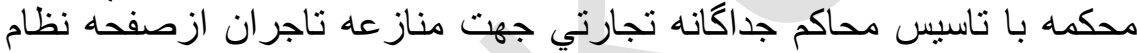

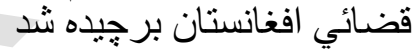

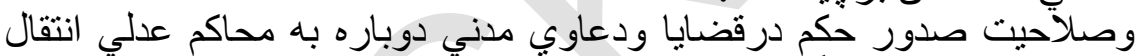

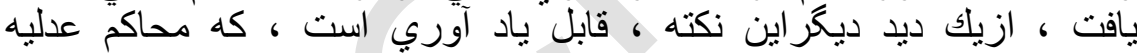

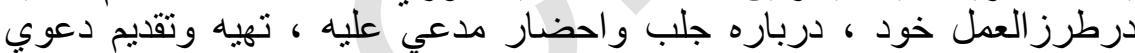

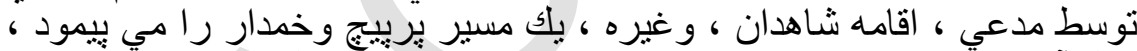

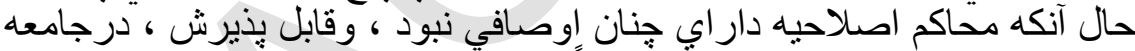

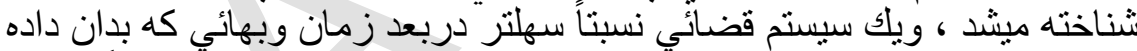

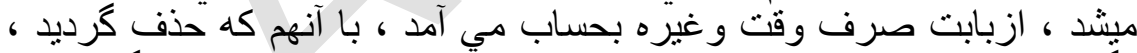

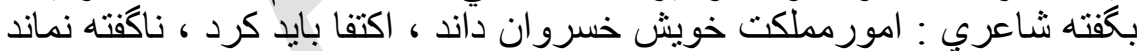

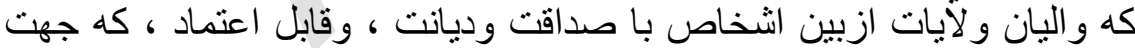

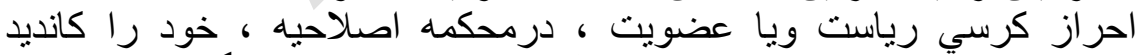

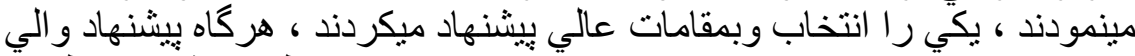

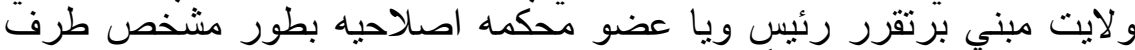

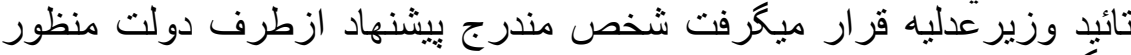

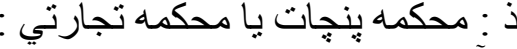

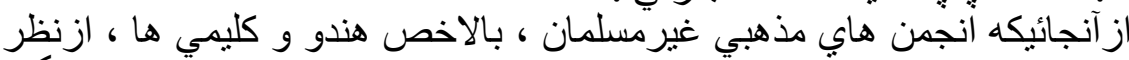

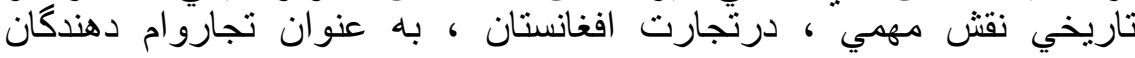




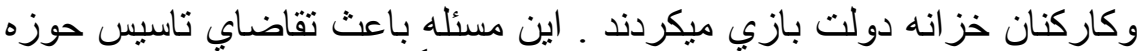

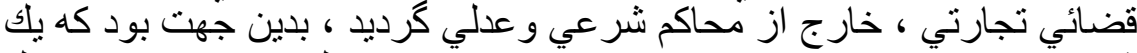

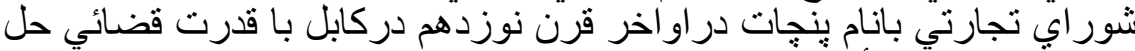

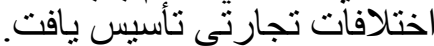

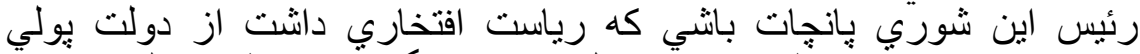

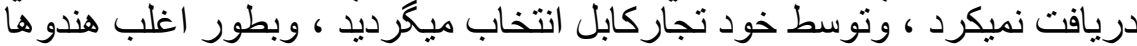

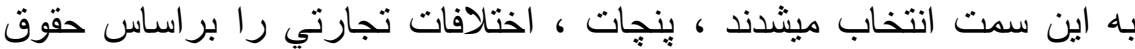

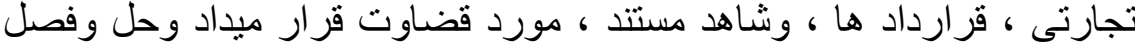

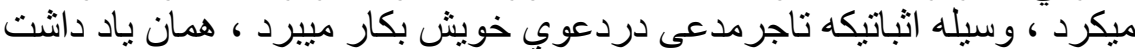

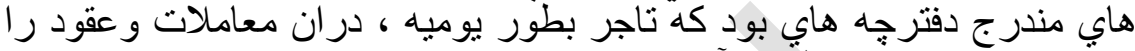

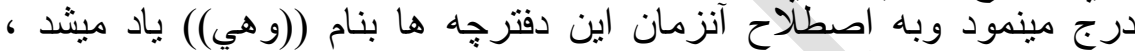

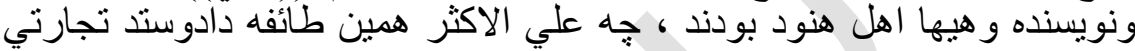

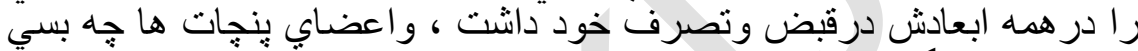

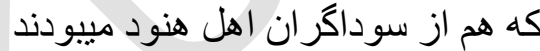

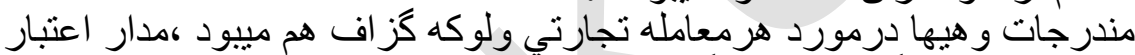

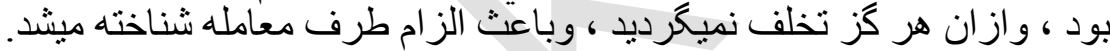

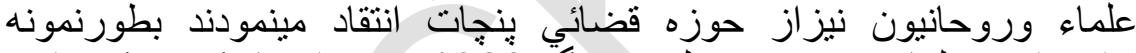

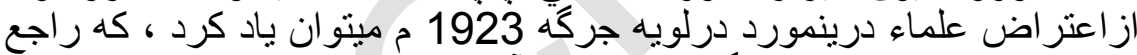

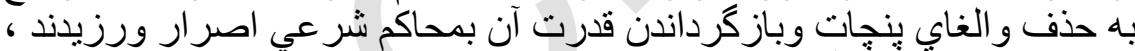

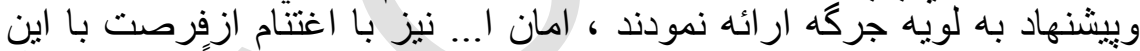

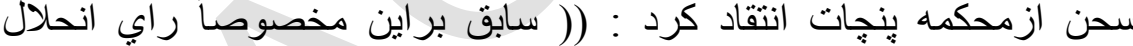

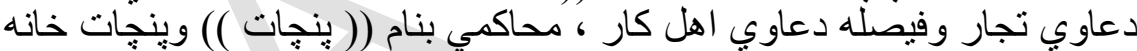

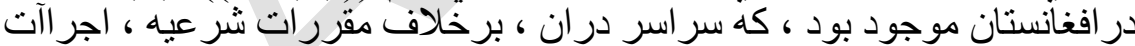

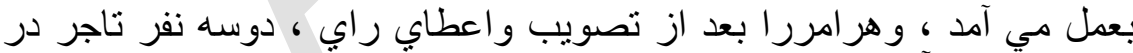

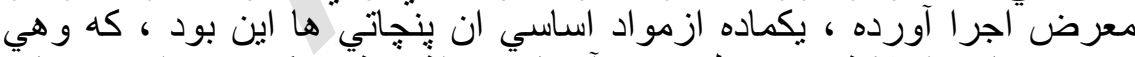

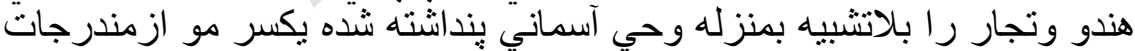

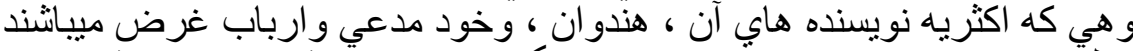

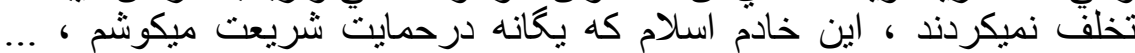

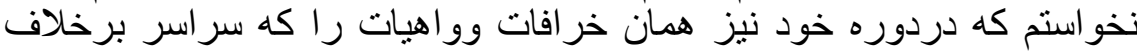

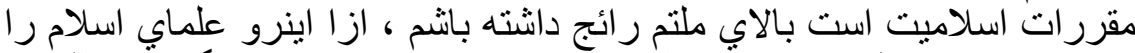

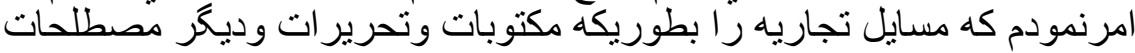

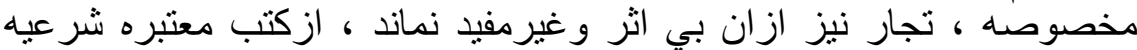


درحيز تحرير در آورده اورا بصورت يك نظام نامه عام فهم شايع نموده ، بِنجات

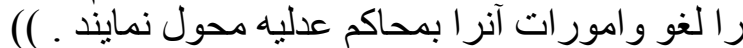

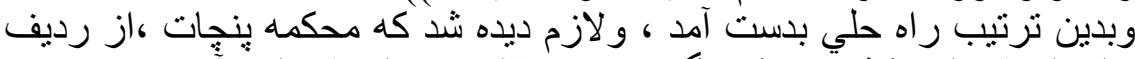

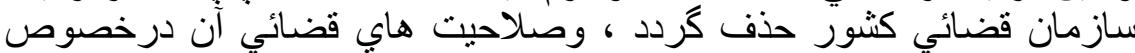

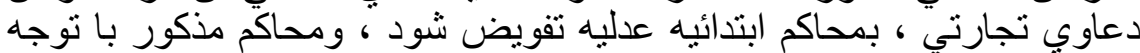

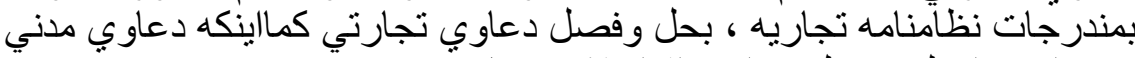

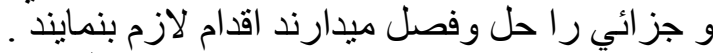

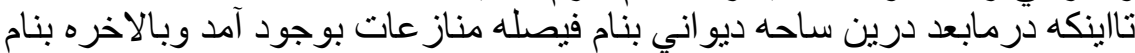

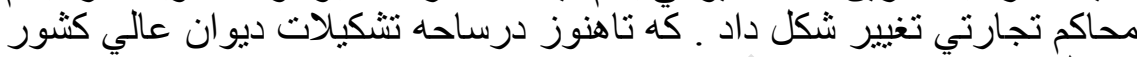

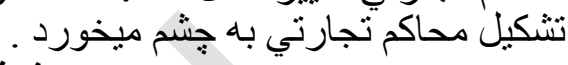
مبحث شانزدهم

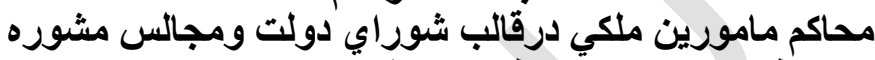

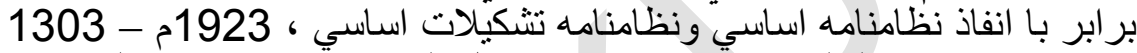

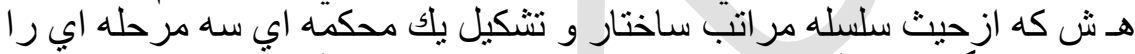

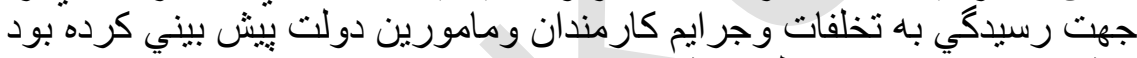

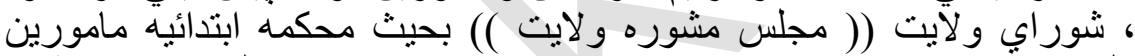

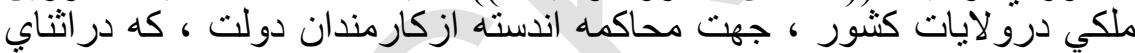

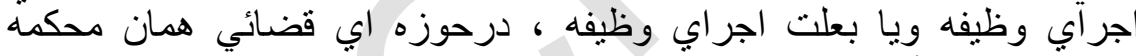

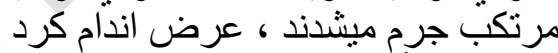

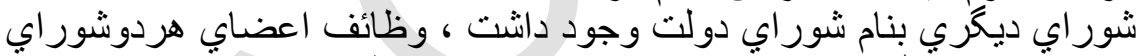

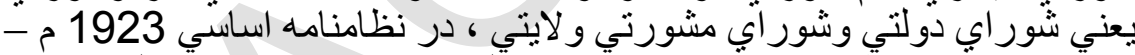

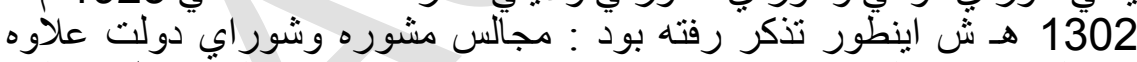

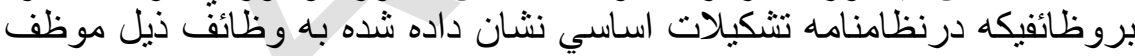
الف :- براي ترقي صناعات ، تجارت ، زر اعت ، معارف ، همه تكاليفي كه

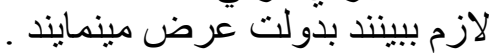

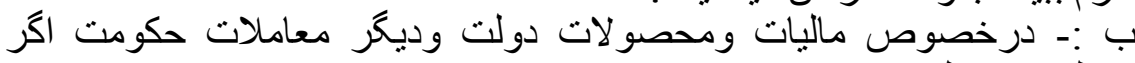

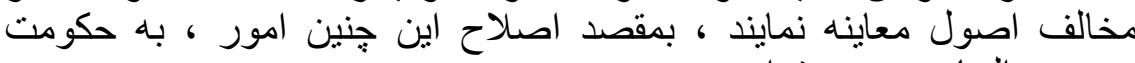

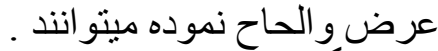

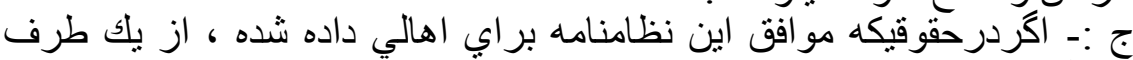

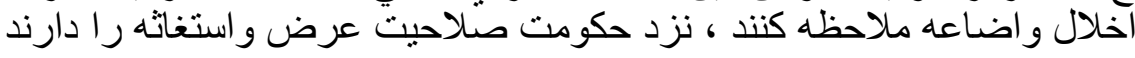




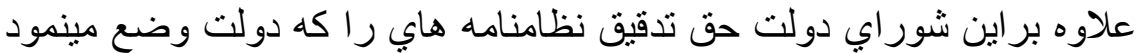

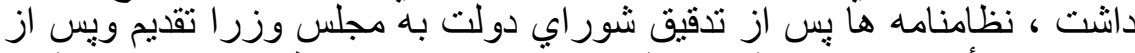

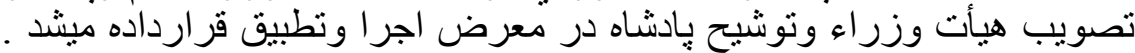

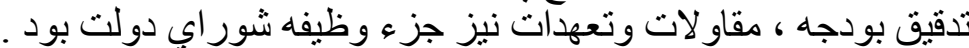

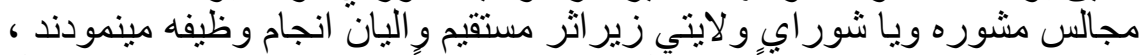

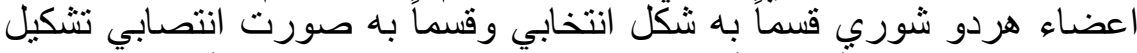

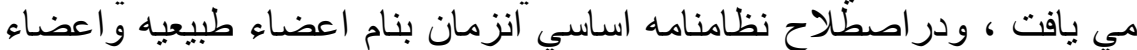

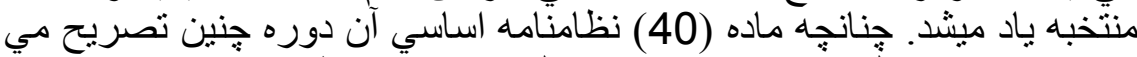

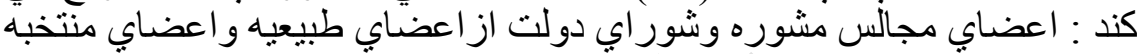

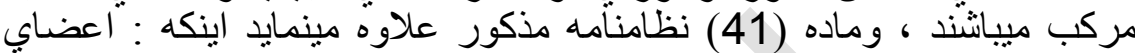

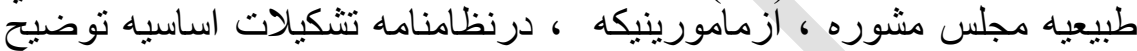

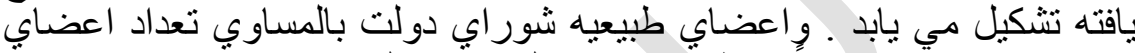

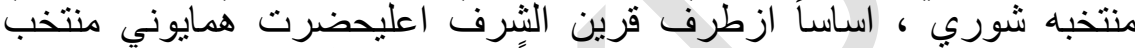

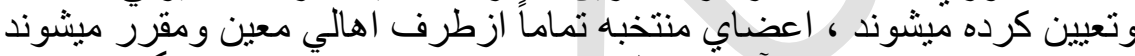

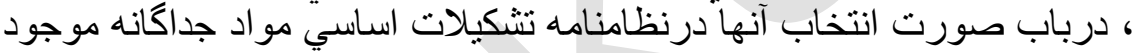

بهمه حال اعضابي شورابي دولت مركب بود از (25) نفر عضو انتخابي و (25)

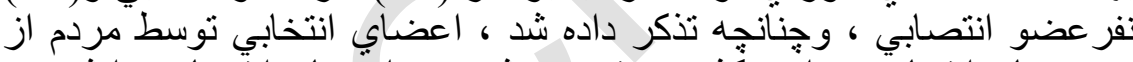

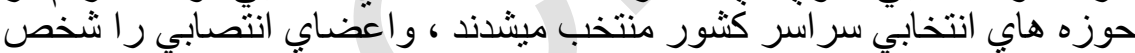

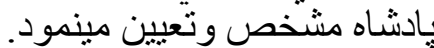
دوره خدمت هردوشور اي سها سال بود ، كه بحيث يك دوره تقنينيه بشمار ميرفت

وبرحسب مصرحات نظامنامه اساسي علاوه بر اعضاي طبيعيه دائمي شور ائي

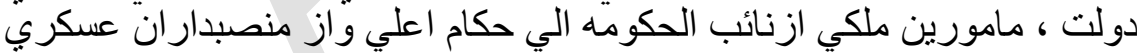

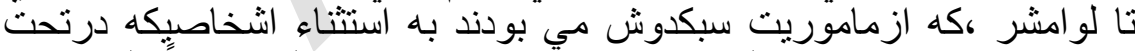

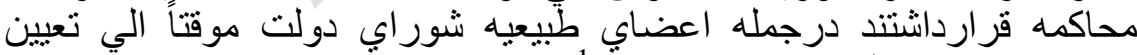

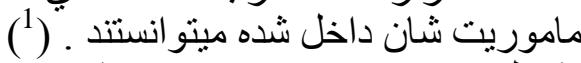

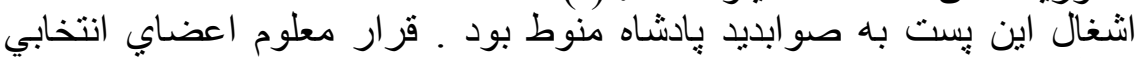
مجالس مشوره توسط كسانيكه بدولت ماليه مي برداه برداختند ،درهرولايت

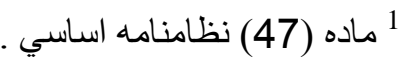




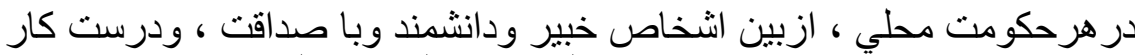

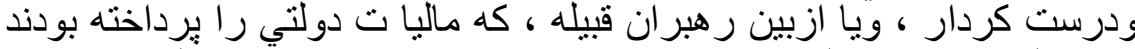

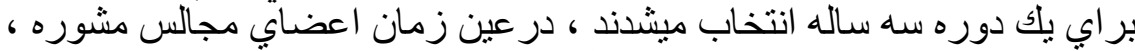

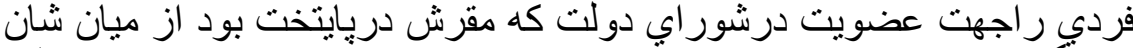

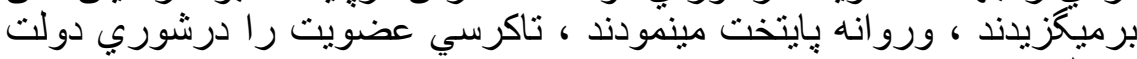

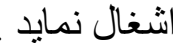

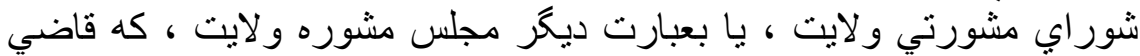

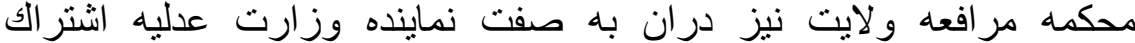

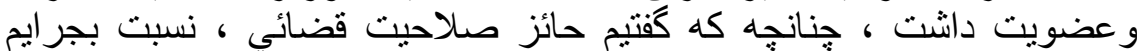

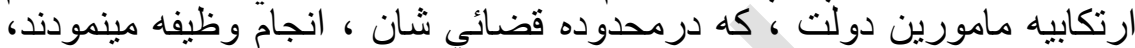

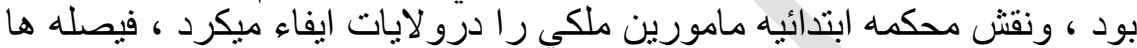

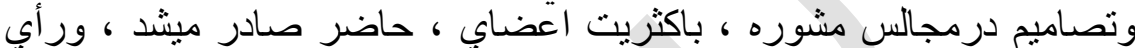

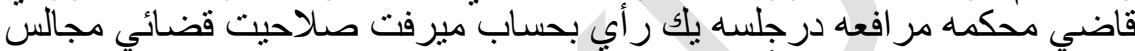

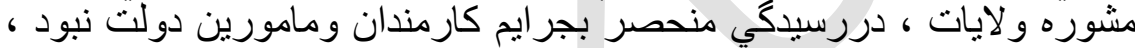

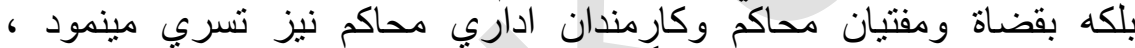

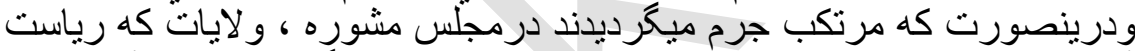

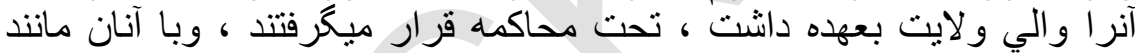

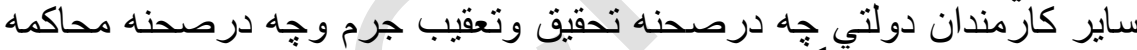

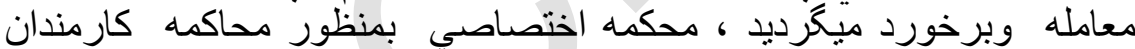

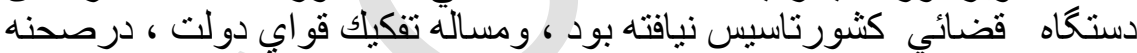

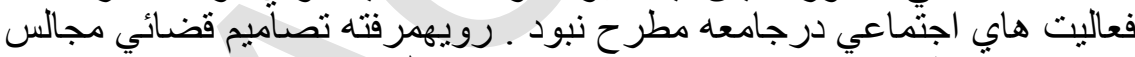

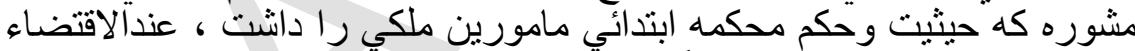

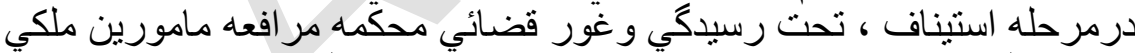

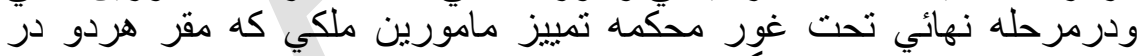

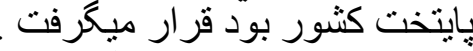

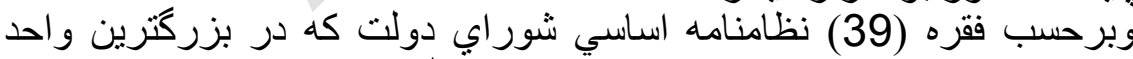

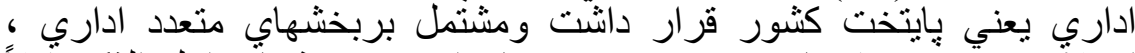

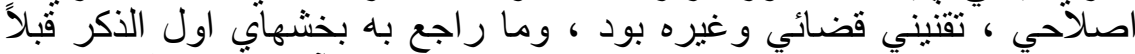

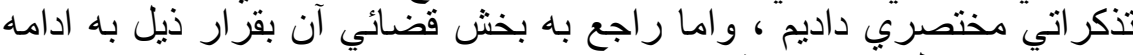

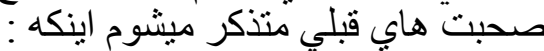

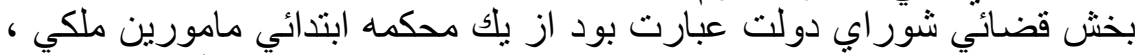

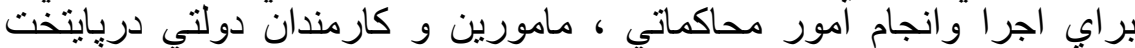

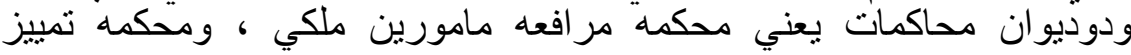


مامورين ملكي براي تمام افغانستان ، البته مقر اين هرسه دستخاه قضائي ،

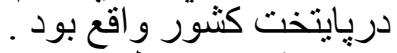

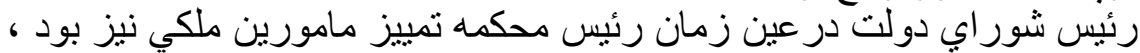

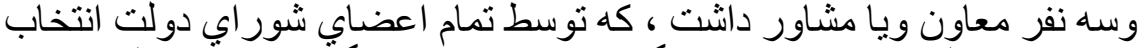

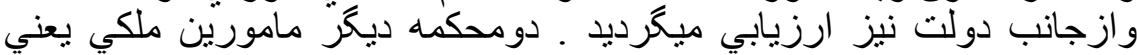

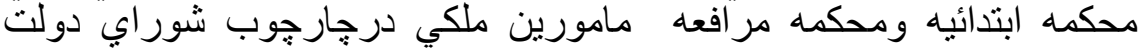

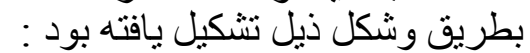

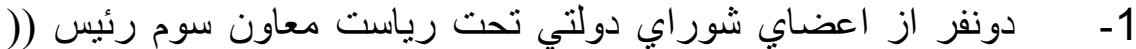

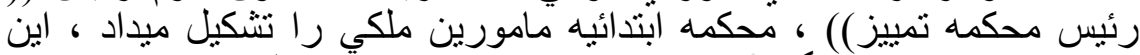

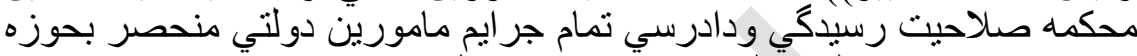

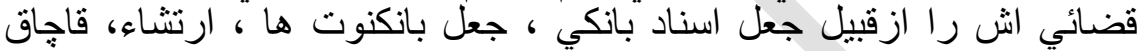

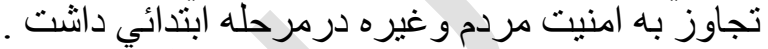

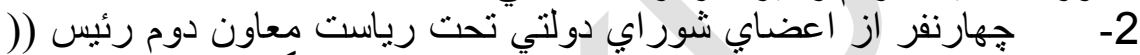

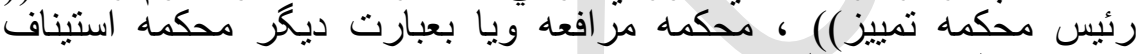

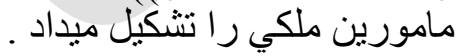

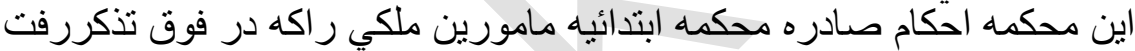

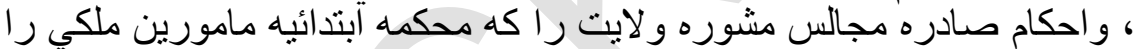

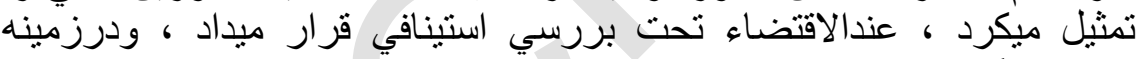

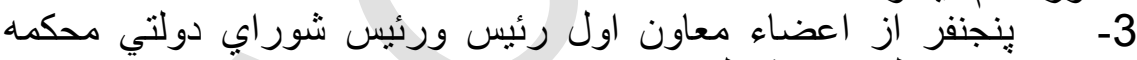

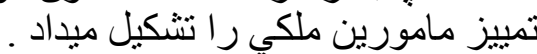

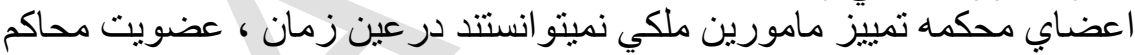
يائين تررا احراز نمايند.

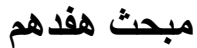

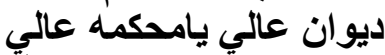

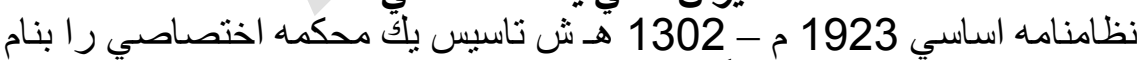
ديوان عالي ، بمنظور رسيدكي ، بجرايم وزراء كابينه اينطور بيش بيش بيني كرده

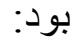

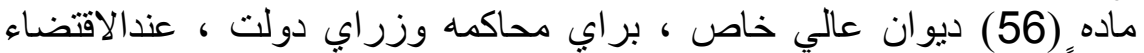

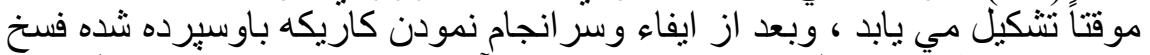

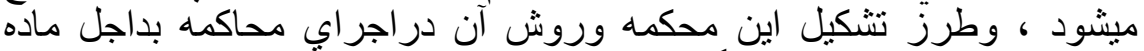

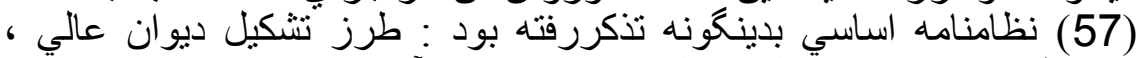

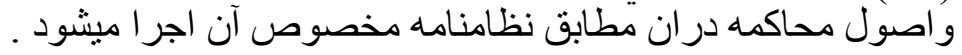


تشكيلات اين ديوان كه قرارفوق به نظامنامه مخصوص بكون آن حواله كرديده بود

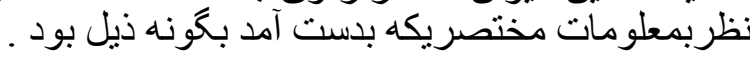

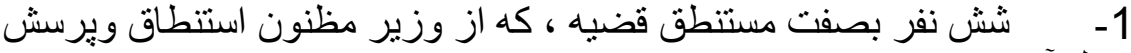

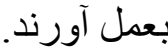

$$
\text { 2 - 2 }
$$

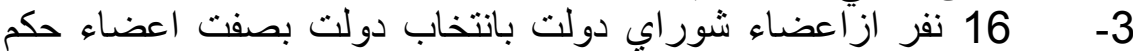

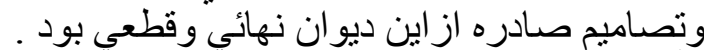

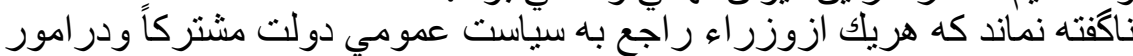

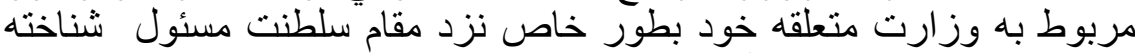

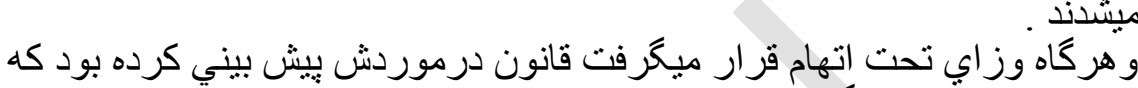

\section{مبحمة نظامي}

بموجب نظامنامه نشكيلات اساسي 1923م -

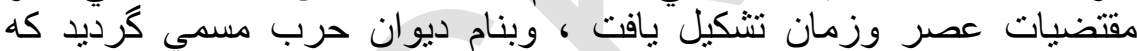

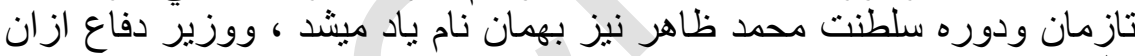

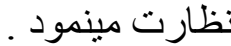
ديوان حرب جرايم متعلق بصاحبمنصبان اردو ، افر اد اد اردو ، و وافراد امنيت ويا

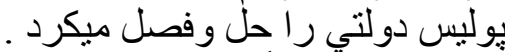

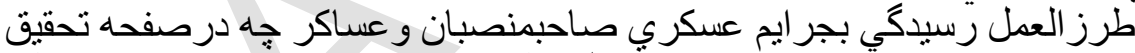
وتعقيب وجهه درصفحه محاكمه ، بذاخل نظامنامه جز اي عسكري تنسيق وتنظيم

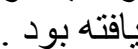
دعاوي ميان افر اد جامعه وصاحبمنصبان عسكري ، و افراد اردو و وامنيه وهكذا

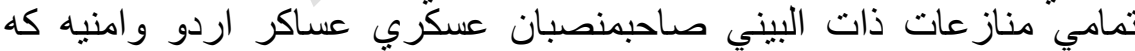

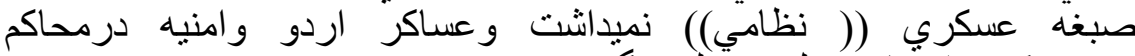

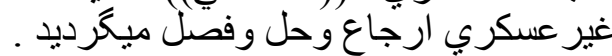

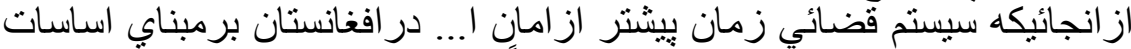

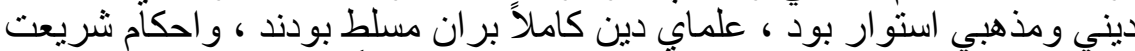

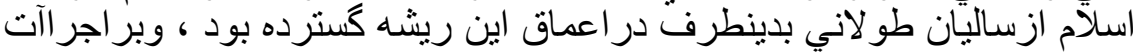

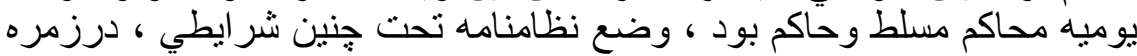


بيشرفت ، قابل توجهي درساحه نظام حقوقي وقانوني در افغانستان بحساب

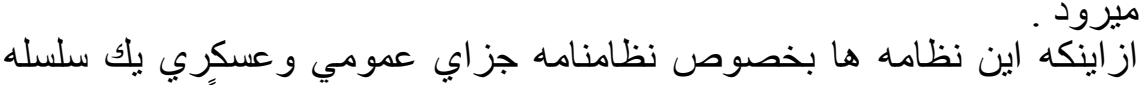

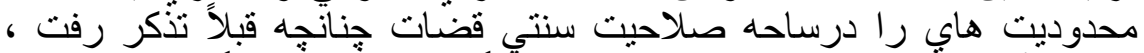

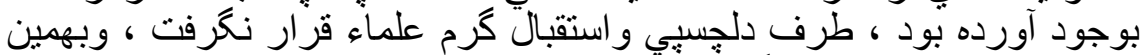

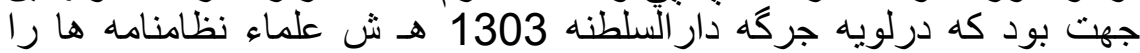

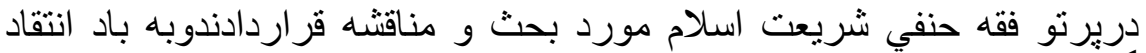
كر فتند .

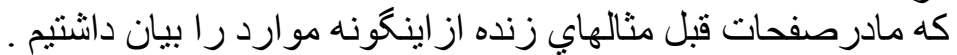

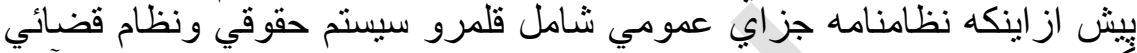

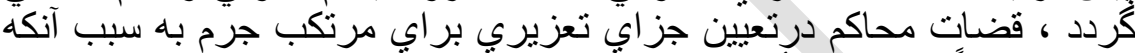

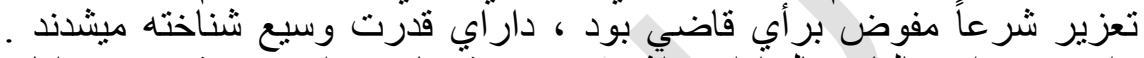

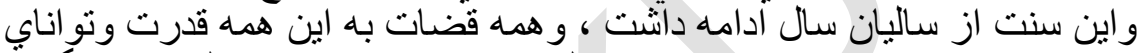

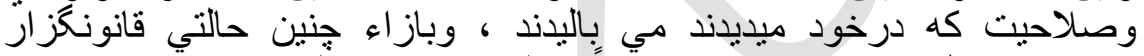

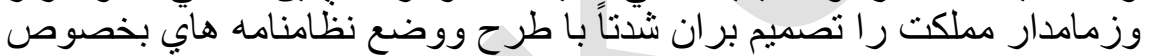

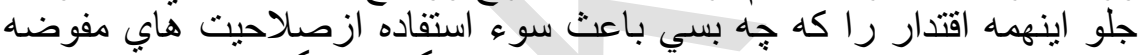

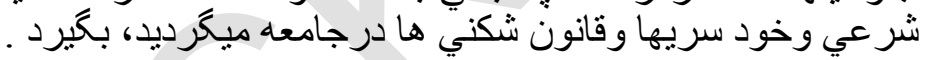




\section{كاربرد قراردادهاى اسلامى

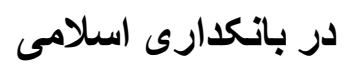

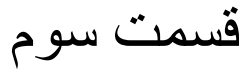 \\ وديعت}

تعريف

بند 59 مـاده 2 قانون بانكدارى، قرارداد وديعت رإ جنين تعريف نموده است:

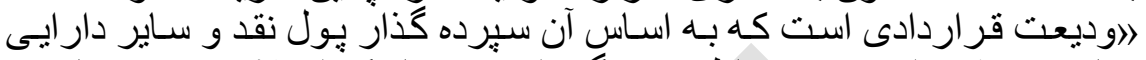

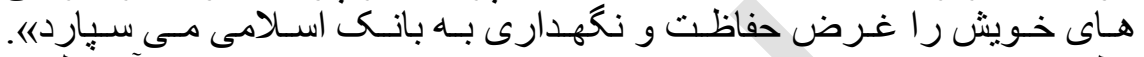

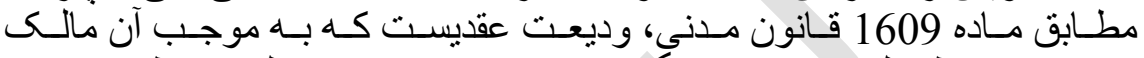

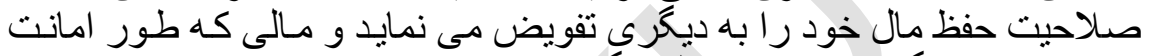

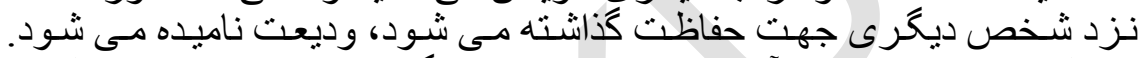

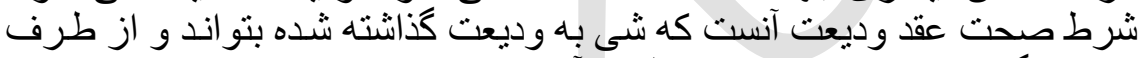

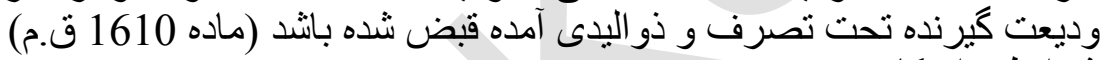
شر ايط و احكام

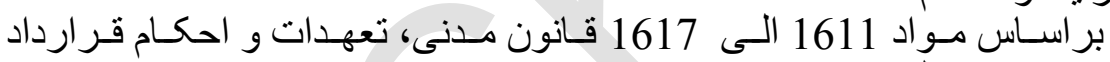
وديعت قرار ذيل يِش بيش بينى شده است

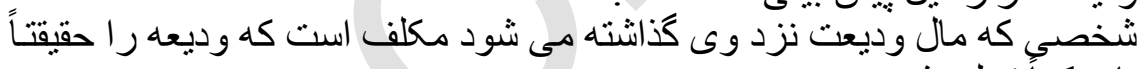

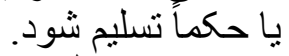

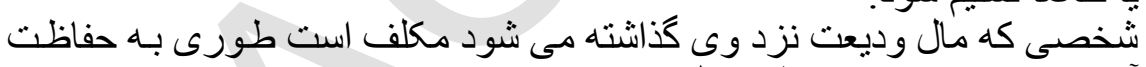

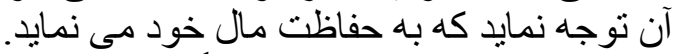

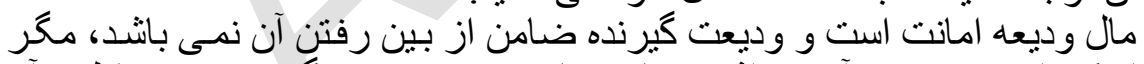

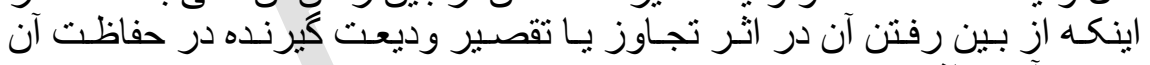
بوجود آمده باتثد.

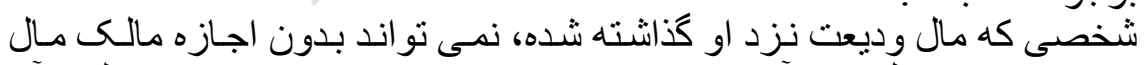

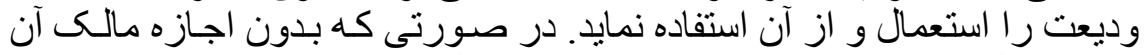

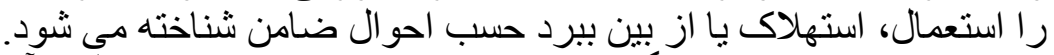

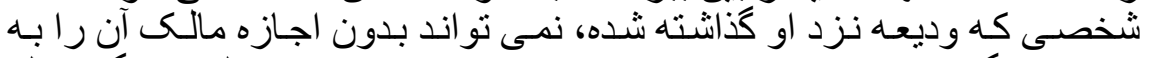

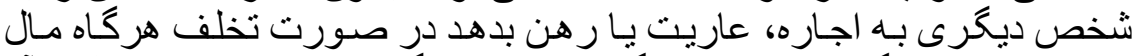

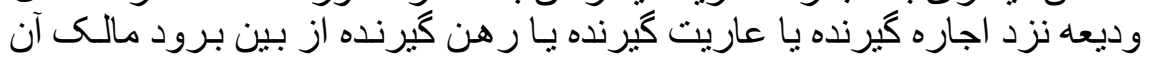


در مطالبه ضمان از اجاره كيرنده، عاريت كيرنده، رهن كير كيرنده يـا شخصسى كه

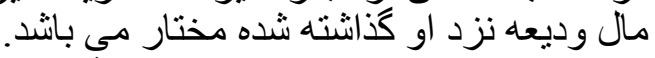
كاربردهاى قر مئ بارداد وديعت

$$
\text { الف) حساب جارى } 1
$$

در بانكهاى اسلامى ماليزيا و كويت، حساب جارى آنه بر اساس عقد وديعت بذئير فتـه

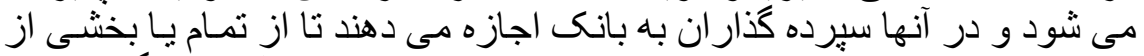

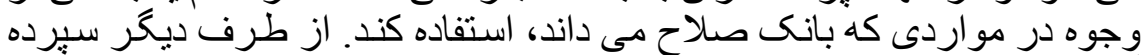

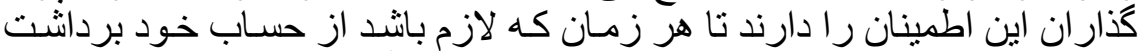

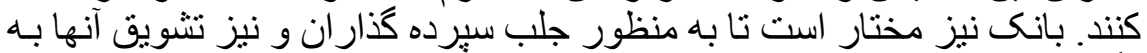

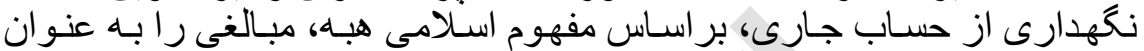

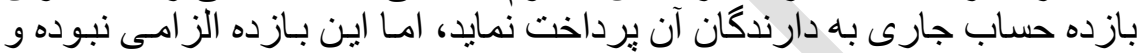

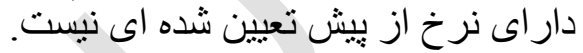

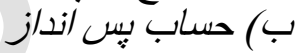

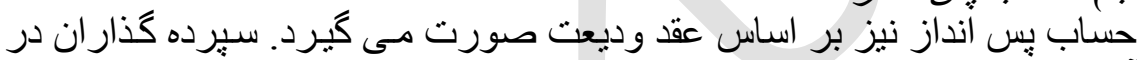

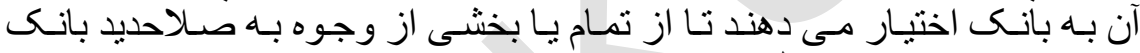

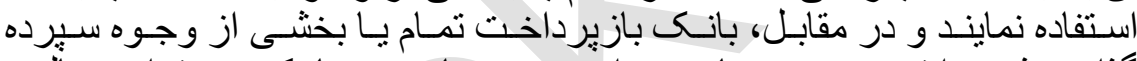

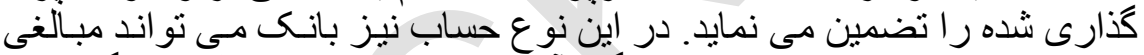

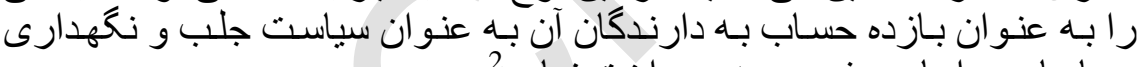

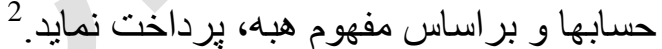

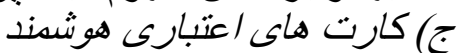

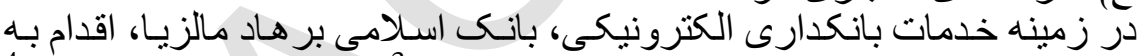

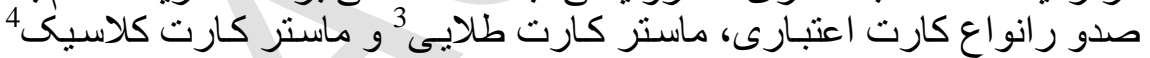

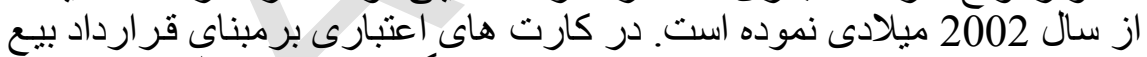

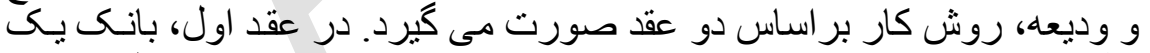

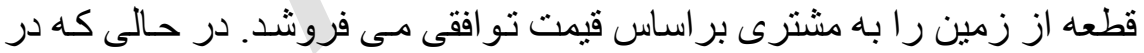

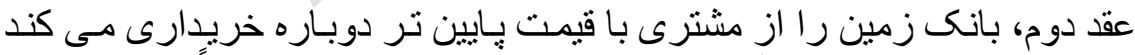

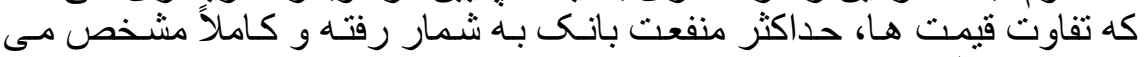

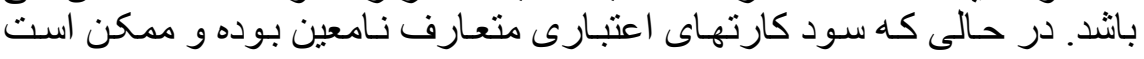

. Current Account. ${ }^{1}$ 2 2. ليلا محر ابى، 》(معرفى روشهاى تأمين مالى اسلامى در كثو هاى مختلف)، ص 3. . Master Card Gold. ${ }^{3}$ . KBI Master Card Classic. ${ }^{4}$ 


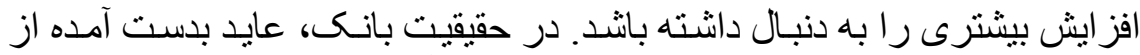

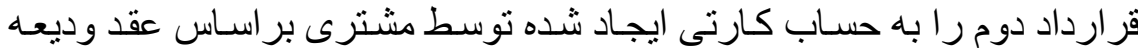

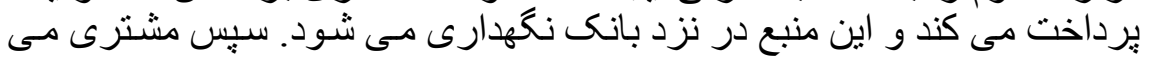

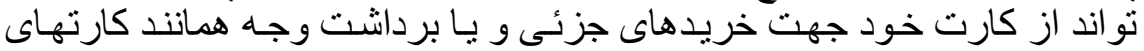

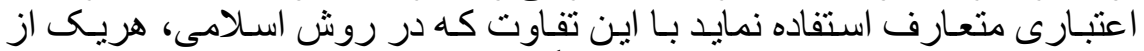

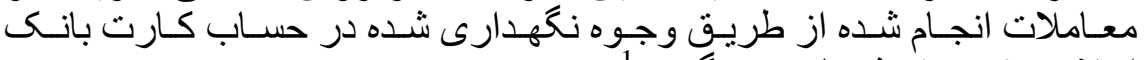

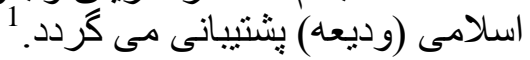

\section{وقف}

وقعريف در لغت بـه معناى حبس، 2 ايستادن، ايستاد ماندن و آر ام كرفتن است. در

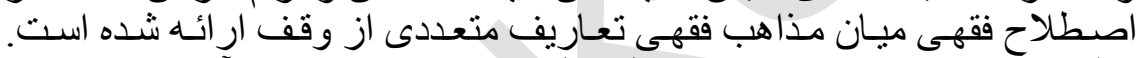

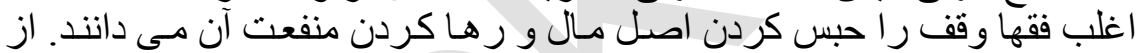

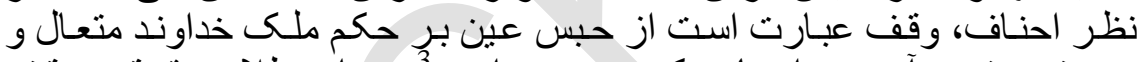
صرف منفعت آن در را اههاى كه دون دوست دارد.

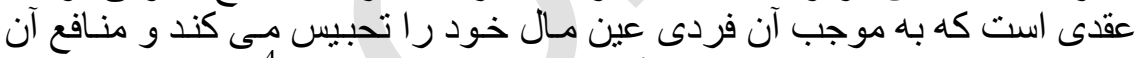

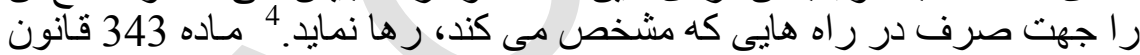

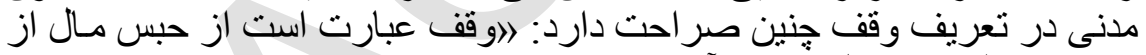

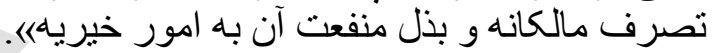
شر ايط و احكام وقف مانه

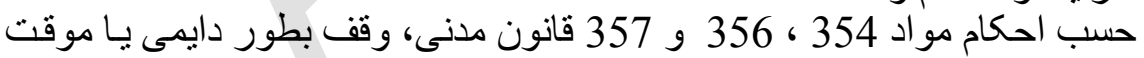

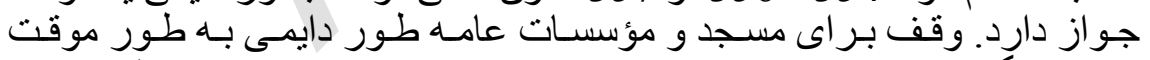

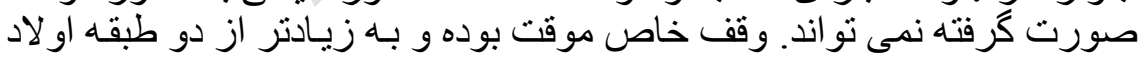

$$
\begin{aligned}
& \text { 1 } 10
\end{aligned}
$$

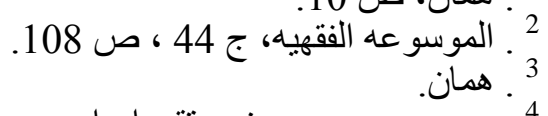

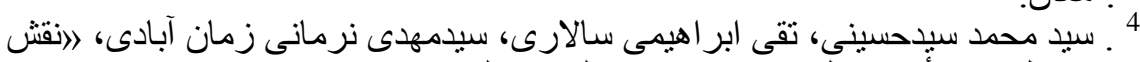

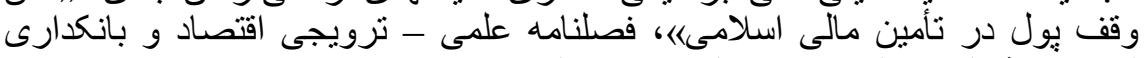

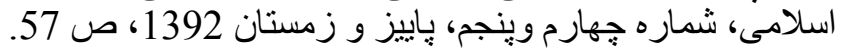




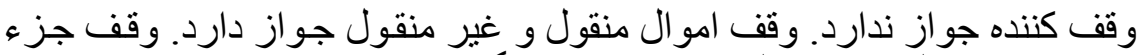

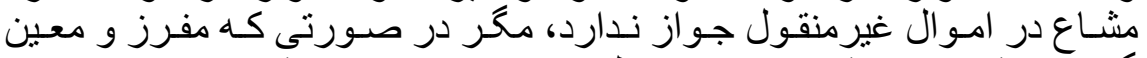

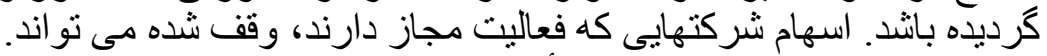

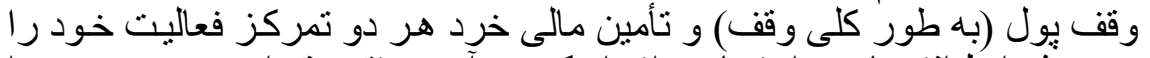

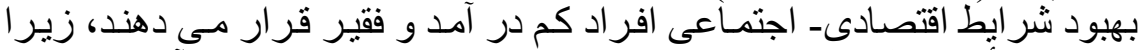

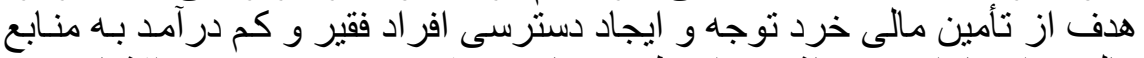

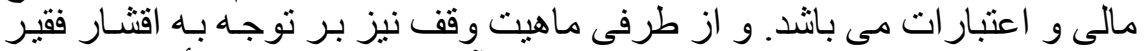

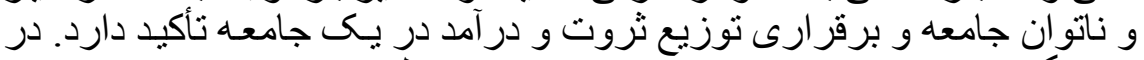

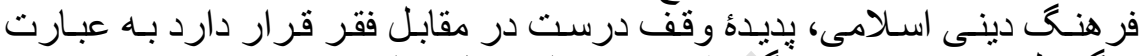

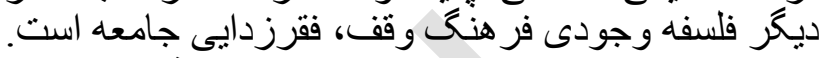
كاربردهاى وقردف

الف) كاربرد وقف در سرمايه كذارى

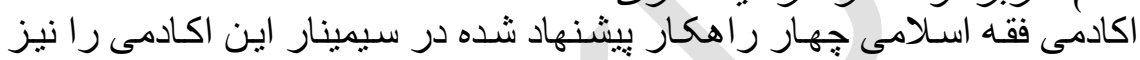

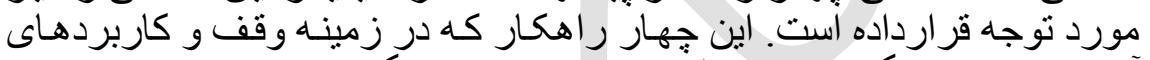

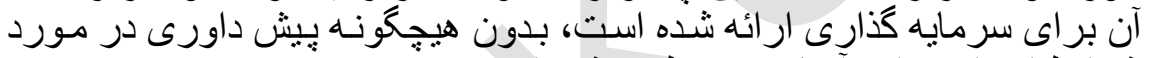

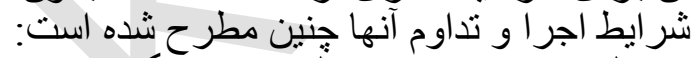

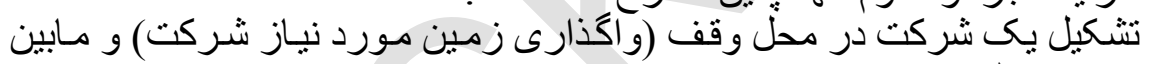

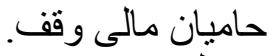

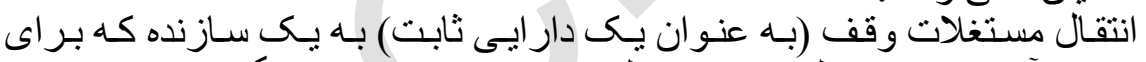

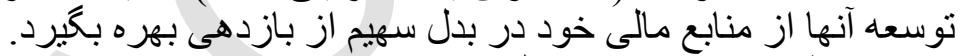

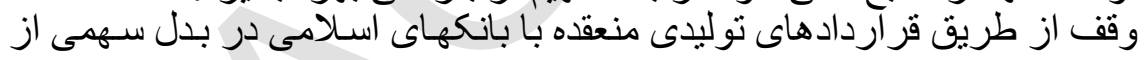

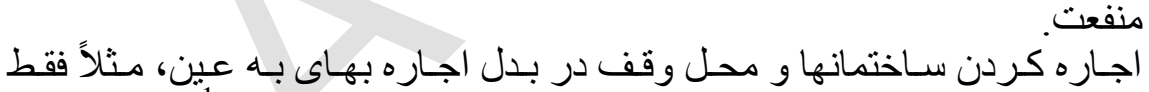

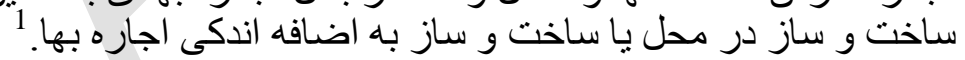

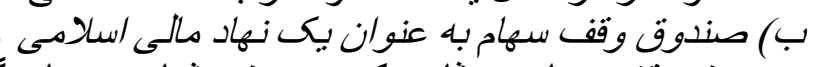

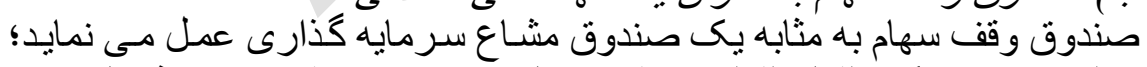

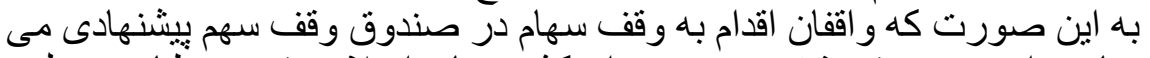

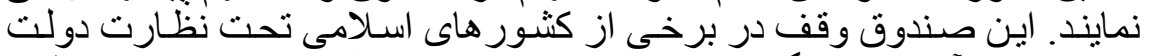

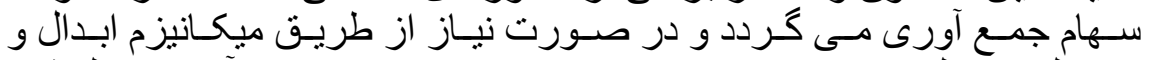

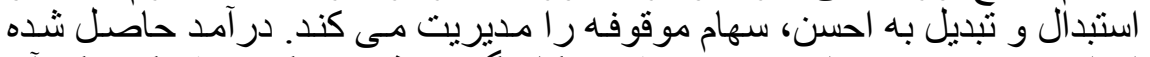

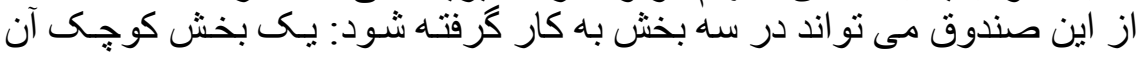

1 . منور اقبال، طريق اله خان، همان، ص 161. 


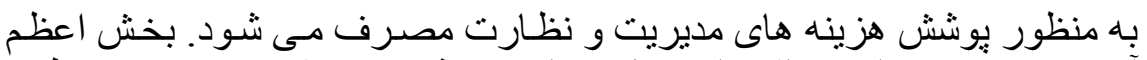

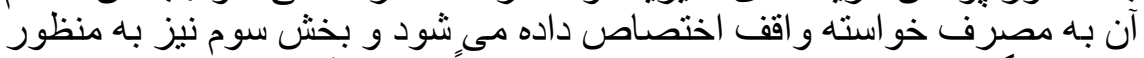

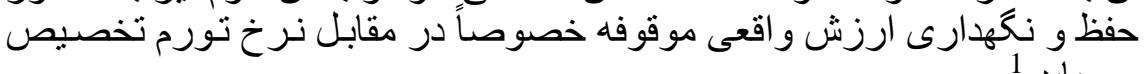
مى يابد. 1

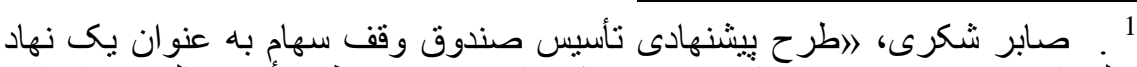

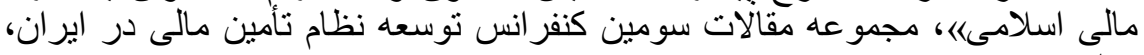
بينا، ص 290. 


\section{بسم الله "ضيائى"}

\section{نظارت قضائى بر اعمال ادارى

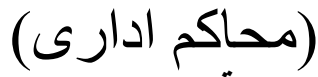

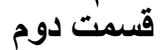

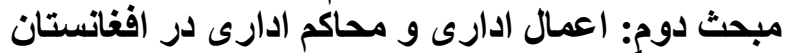

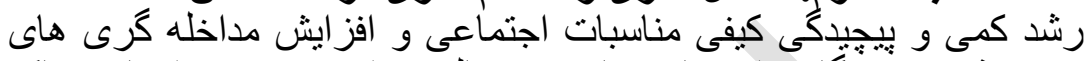

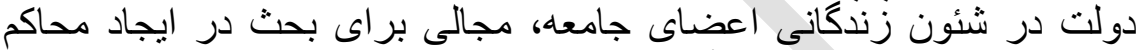

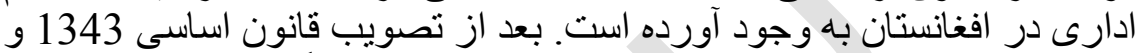

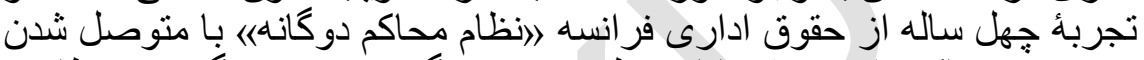

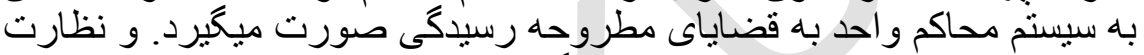

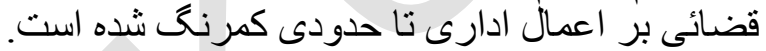

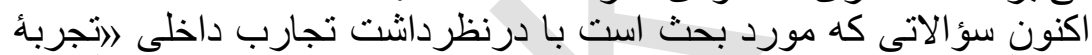

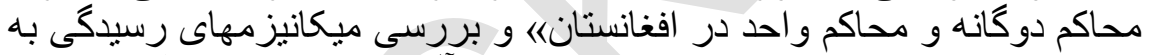

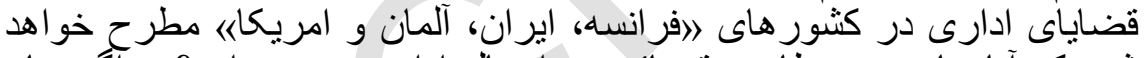

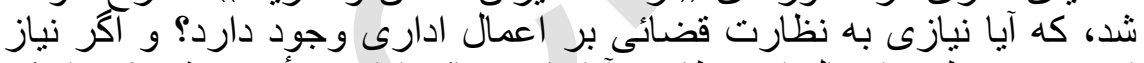

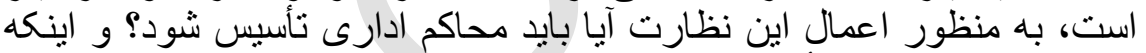

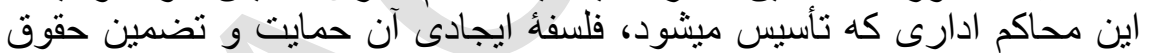

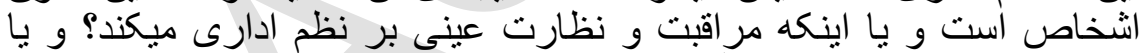

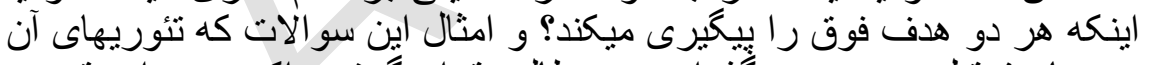

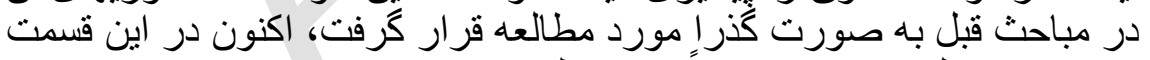

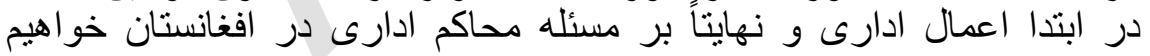

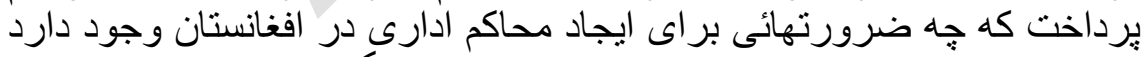

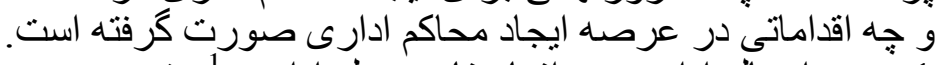

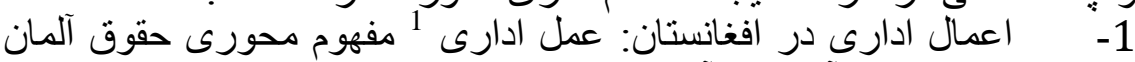

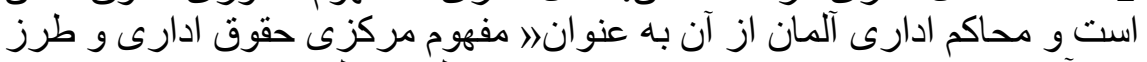

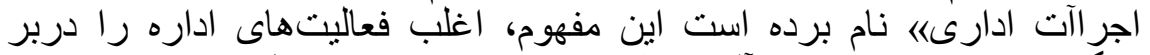

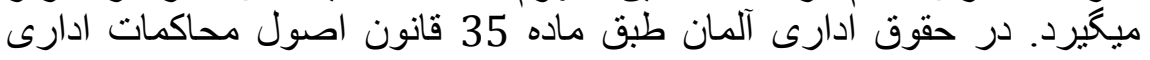

${ }^{1}$ Admins Tra Tive Act, verwaltung sakt 
آلمان مصوب 1976 عمل ادارى شامل هر دستور، تصميم و يام يأ هراقدام

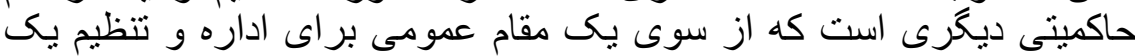

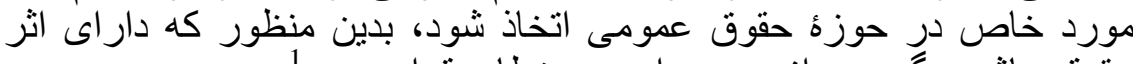

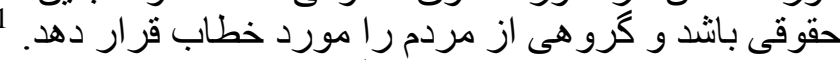

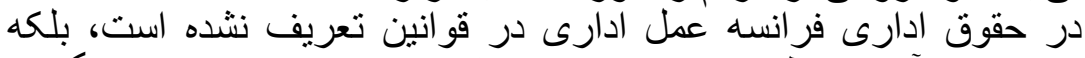

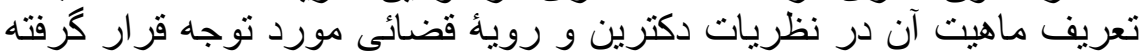

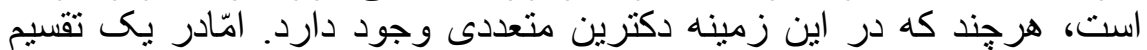

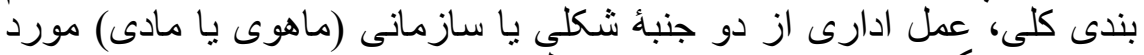

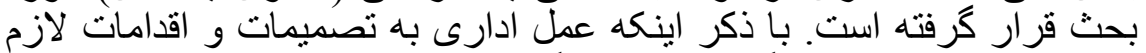

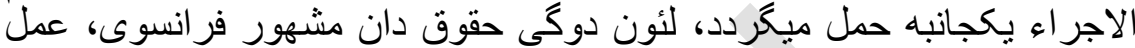

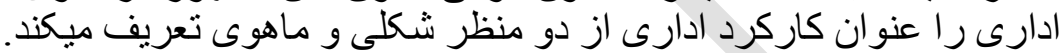

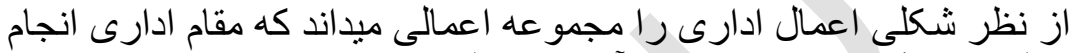

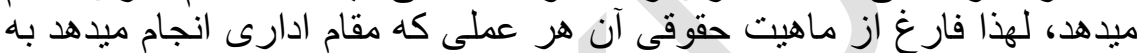

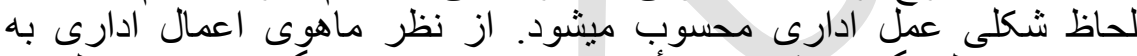

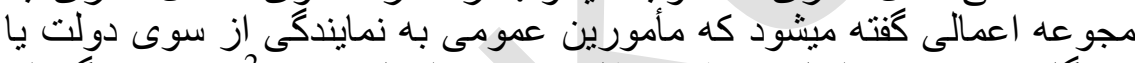

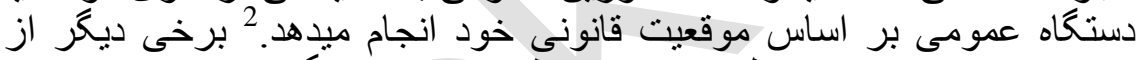

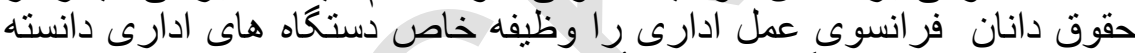

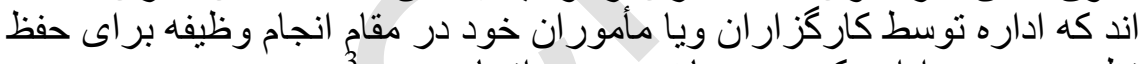

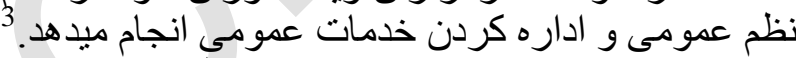

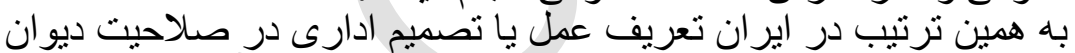

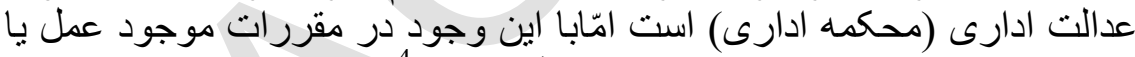

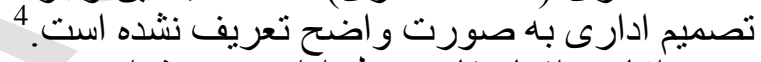

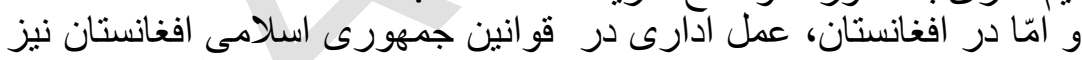

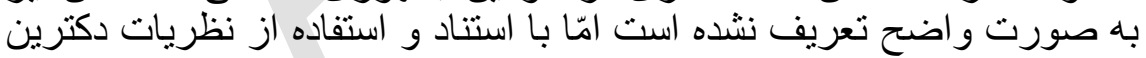

1 هداوند، مهذى و ديكران، آئين هاى تصميم كيرى در حقوق ادارى، انتشارات

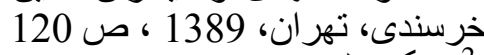

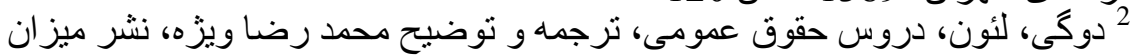

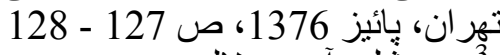

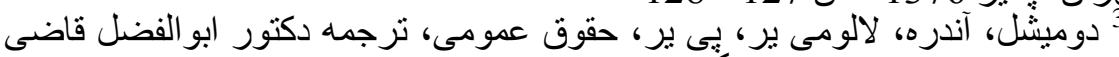

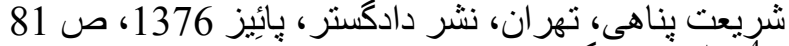

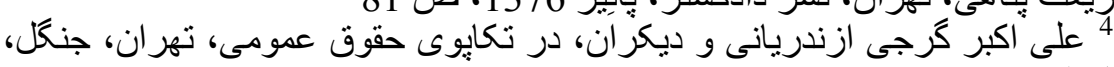

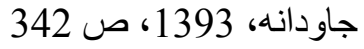


و احكام قضائى جنين برداشت ميشود كه اعمال اداره به صورت عمده به دو

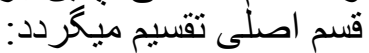

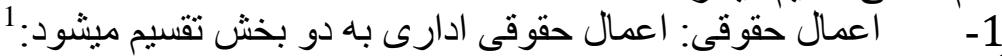

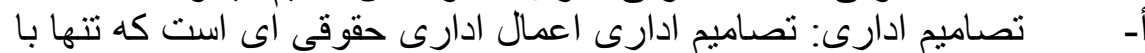

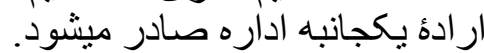

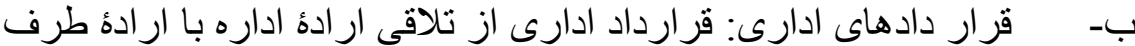

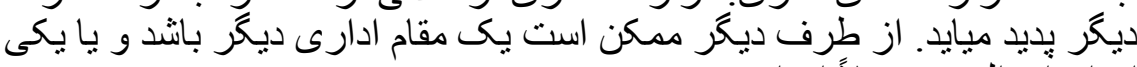

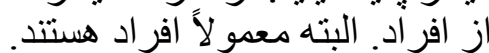

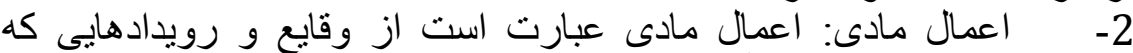

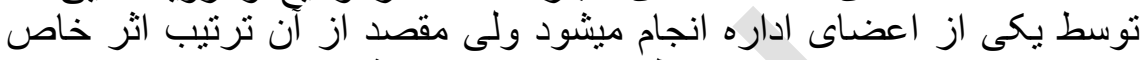

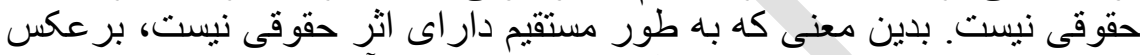

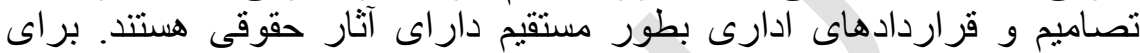

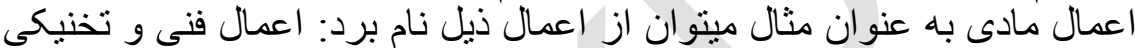

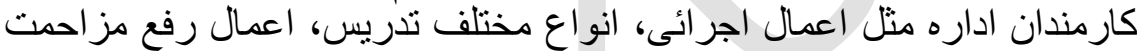

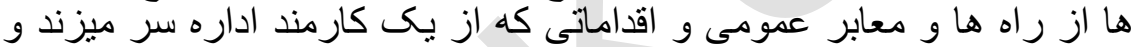

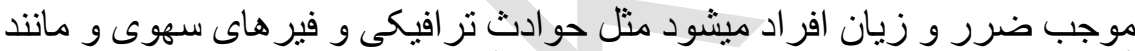

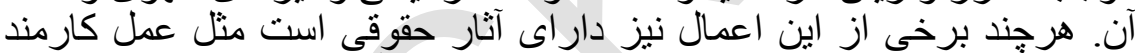

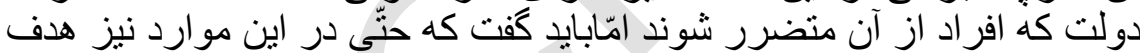

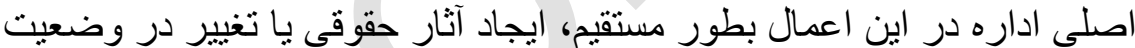
حقوقى افر اد نيست.

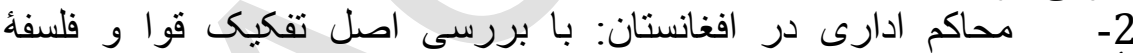

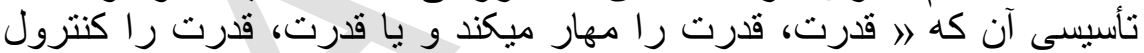

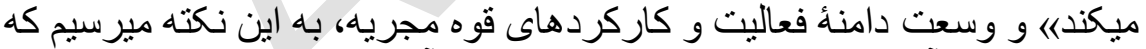

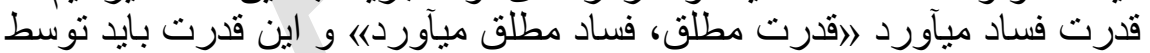

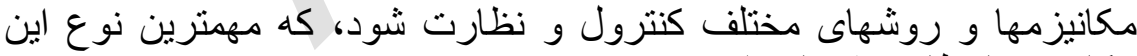
مكانيزم ها نظارت قضيزئي است.

1 دانش، سرور، حقوق ادارى افغانستان، انتشار ات دانشحاه ابن سينا، كابل، بهار 1394

2 دانش، سرور، حقوق ادارى افغانستان، انتشارات دانشگاه ابن سينا، كابل، بهار 1394 صن 374 
قبل از ايجادِ ميكانيزم نظارت قضائى بر اعمال ادارى، بهانه اصطلاح

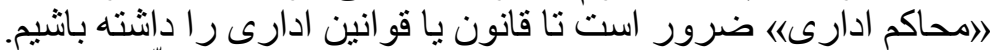

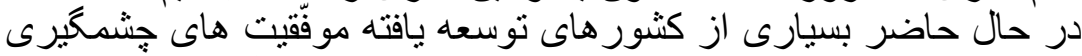

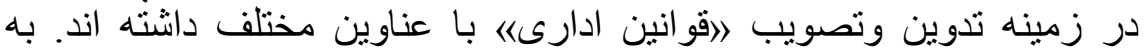

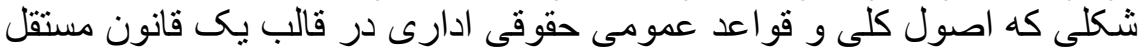

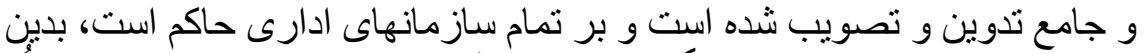

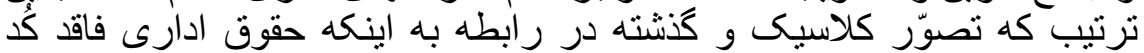

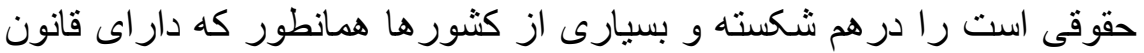

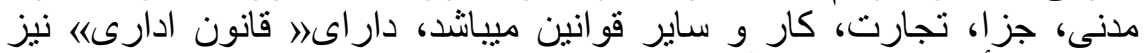

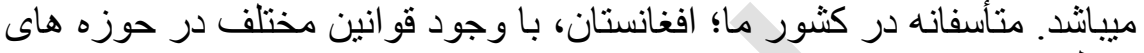

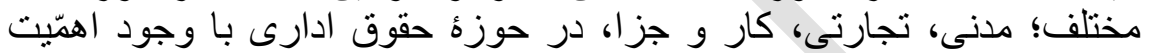

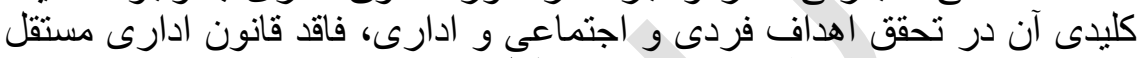

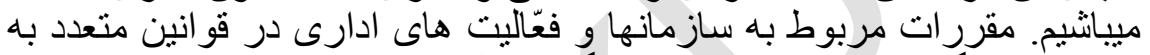

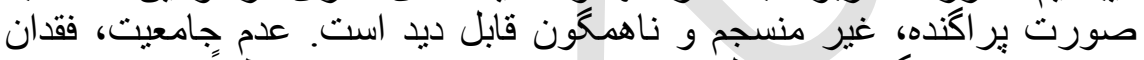

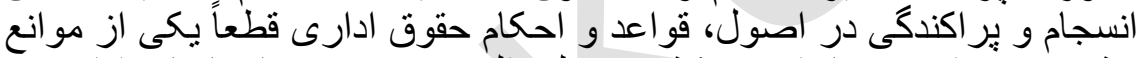

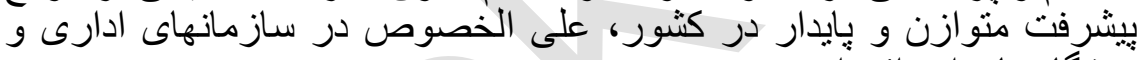
دستخاه هاى اجر ائى أست دون.

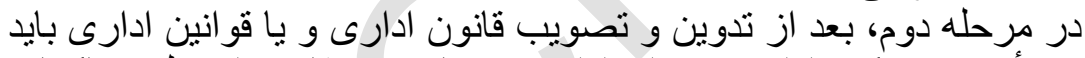

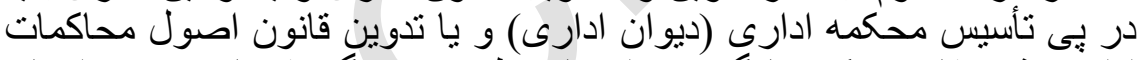

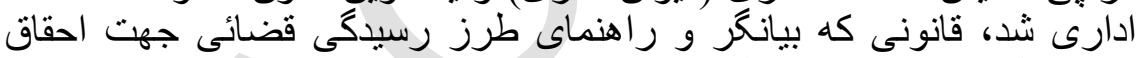

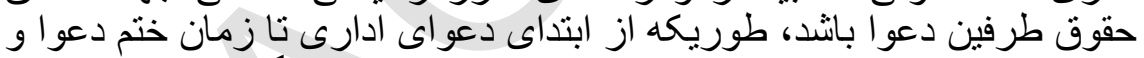

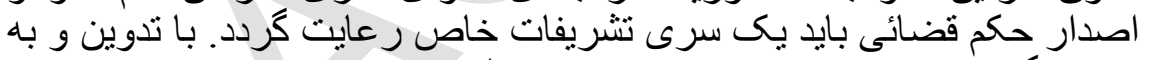

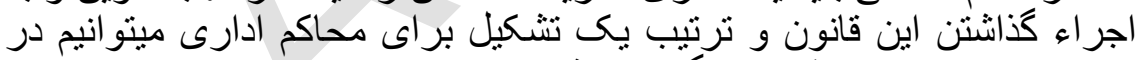

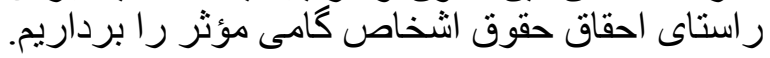

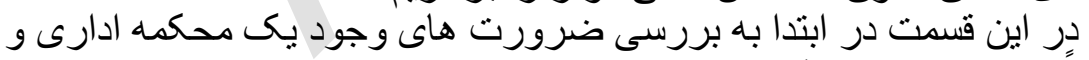

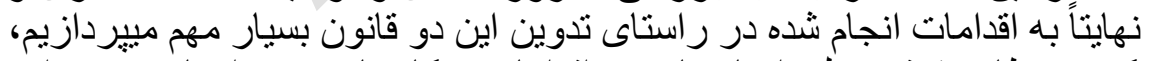

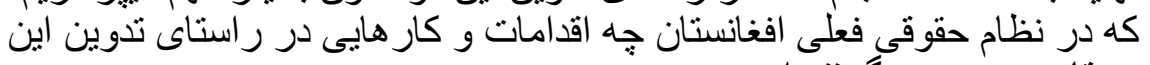

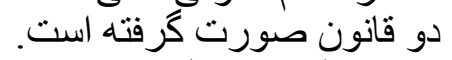
مسئله و سؤال اينجاست كه آيا در نظام حقوقى افغانستان نيازى بانه ايجان ايجاد

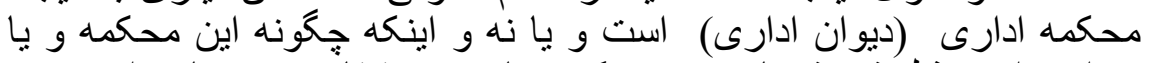

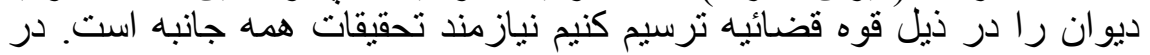

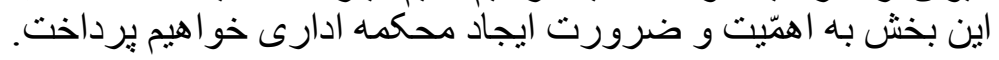




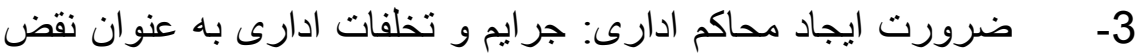

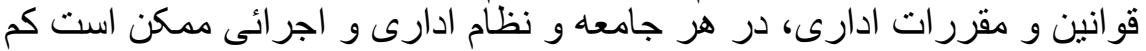

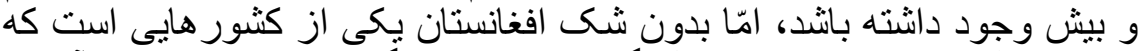

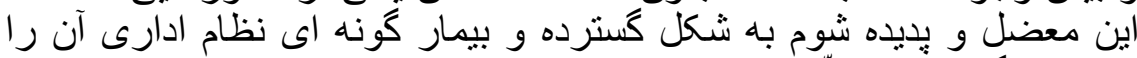

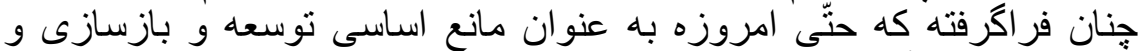

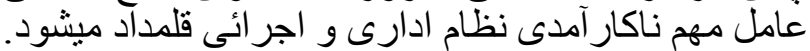

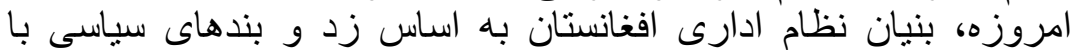

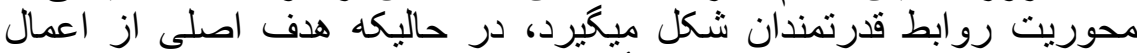

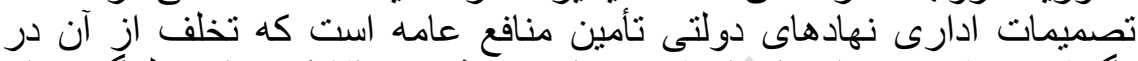

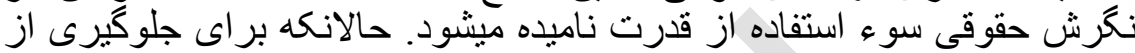

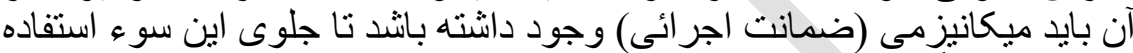

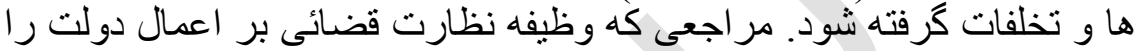

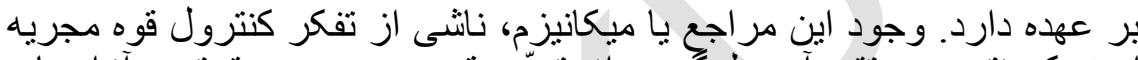

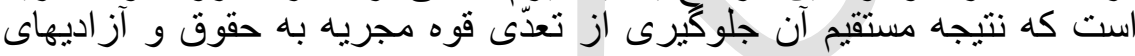

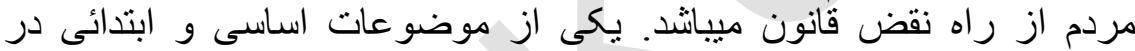

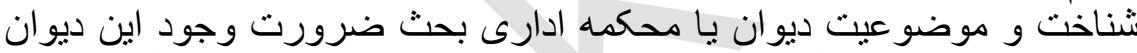

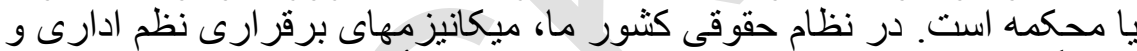

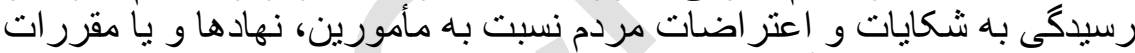

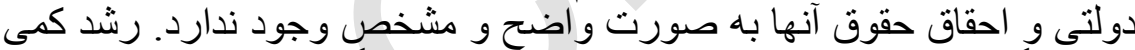

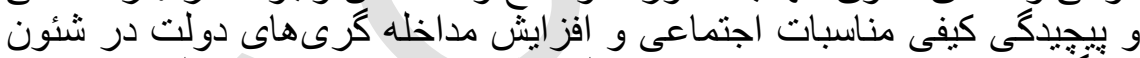

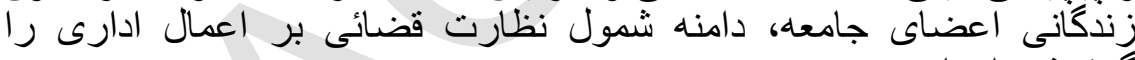
كسترش داده است.

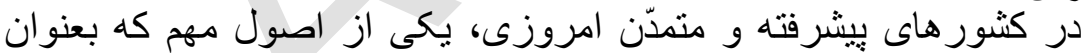

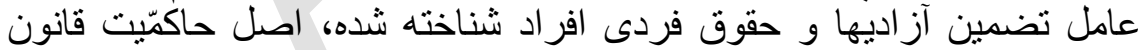

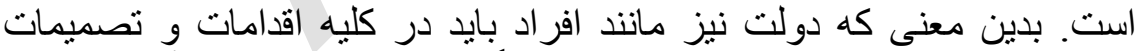

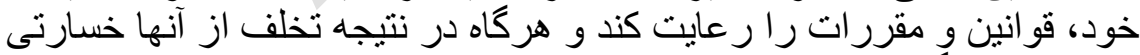

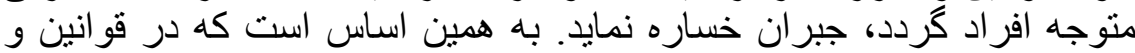

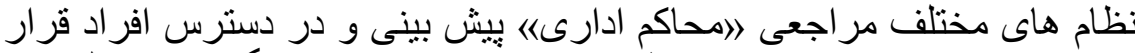

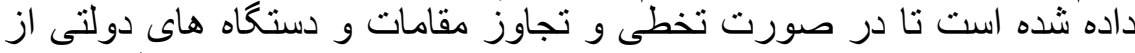

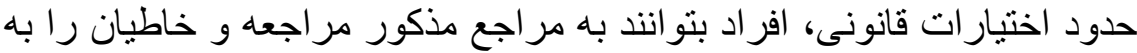

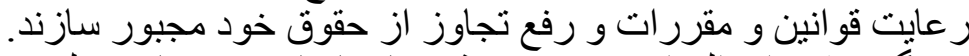

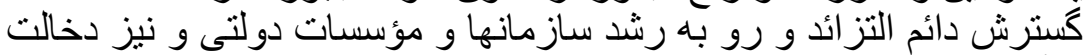

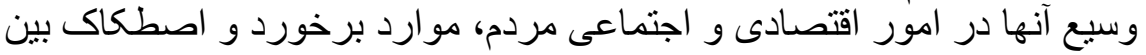


مردم و دولت و كاركز ار ان دولتى را امرى اجتناب نابذيزير و حتمى ساخته است.

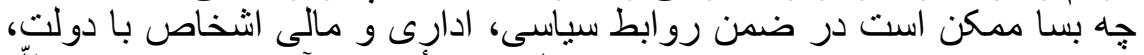

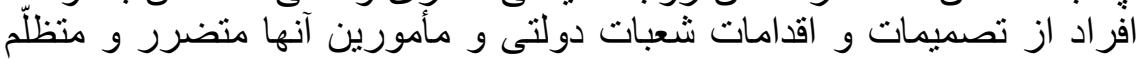

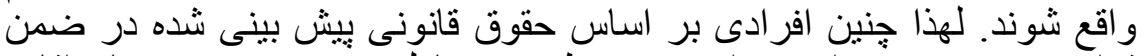

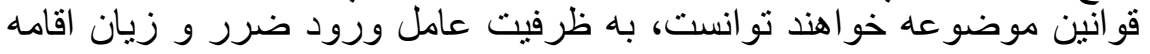

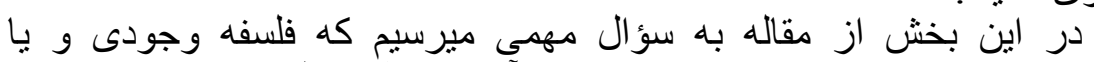
دعوى نمايند.

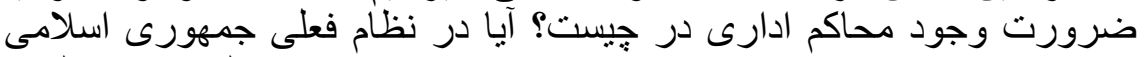

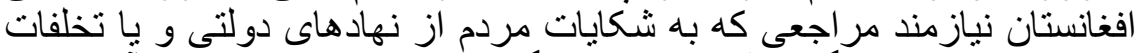

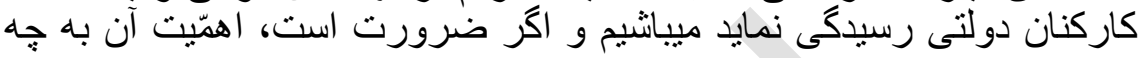
ميز ان استب دئ ماده 120 قانون اساسى:

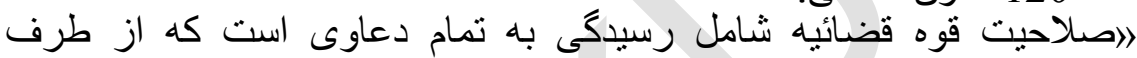

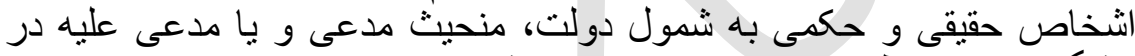

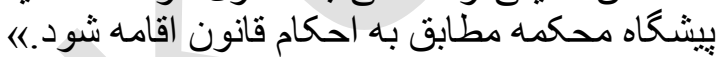

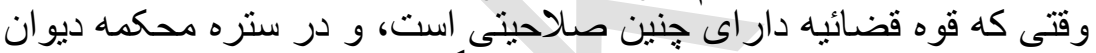

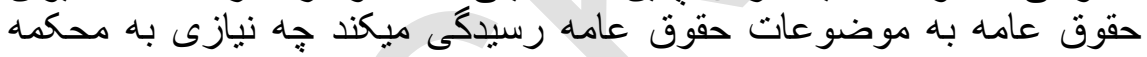

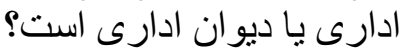

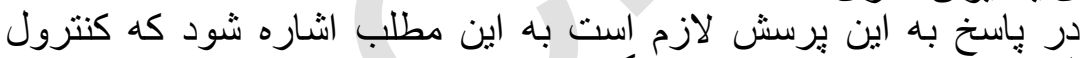

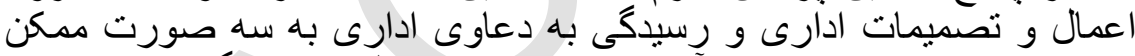

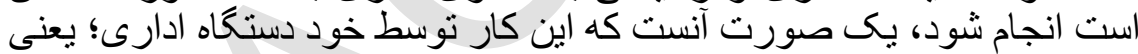

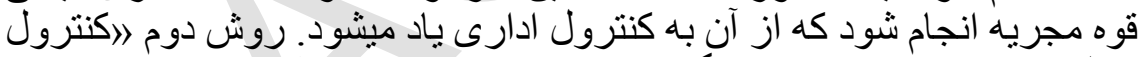

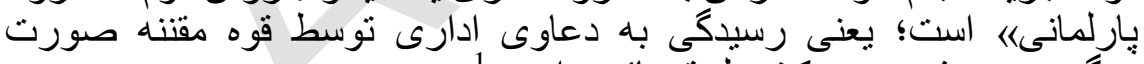

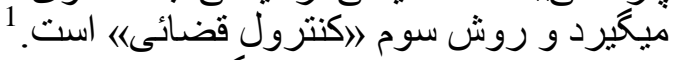

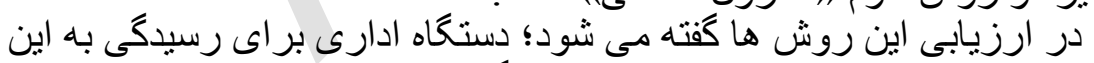

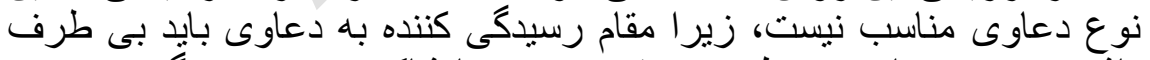

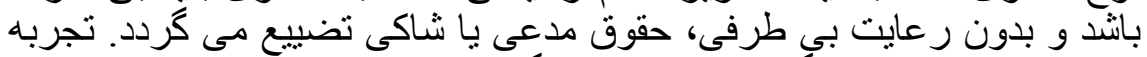

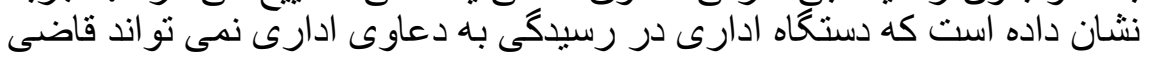
بى طرف بانثد.

1 ـهدايت نيا كنجى، فرج الله، جايكاه ديو ان عدالت ادارى در رسيدكى به شكايات مردم

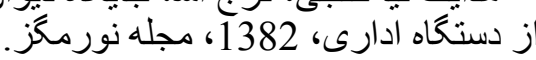




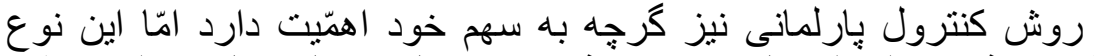

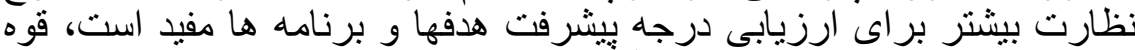

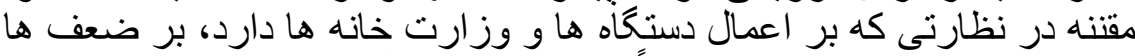

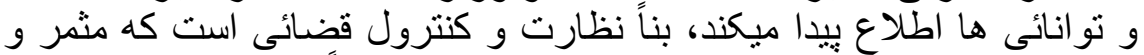

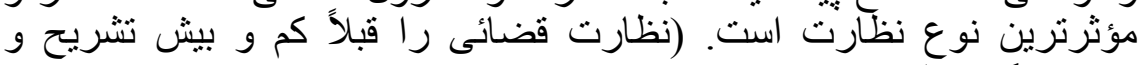

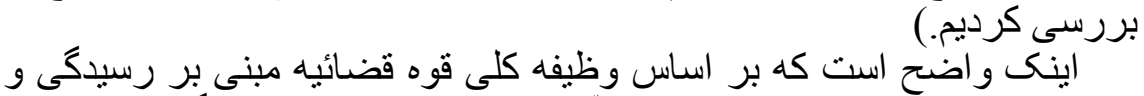

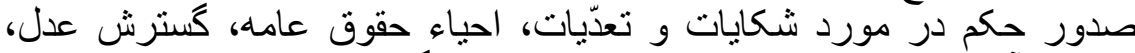

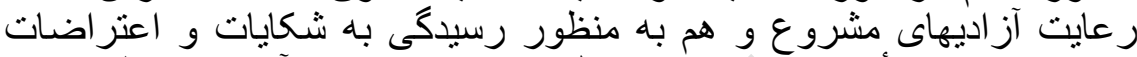

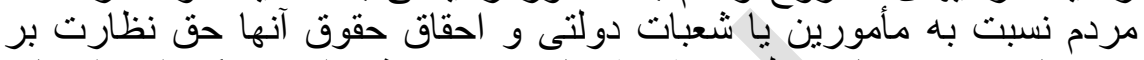

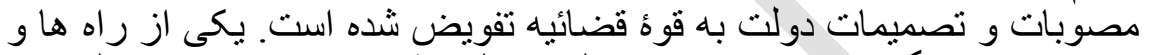

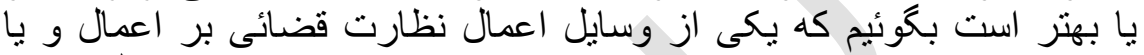

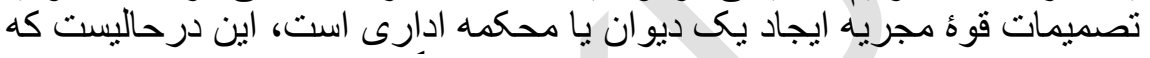

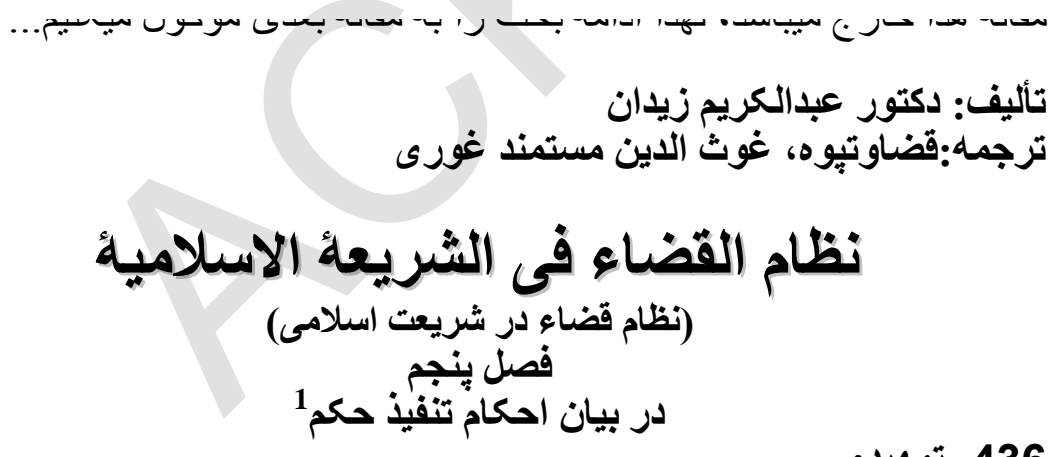

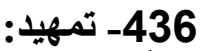

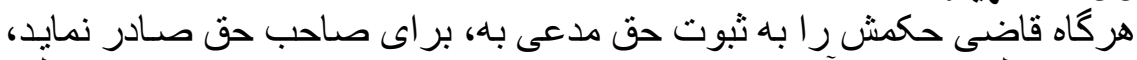
اينجا سو الى بيش مى آيد از مرجع قانونى كه در صور به برت خوددارى محكوم عليه

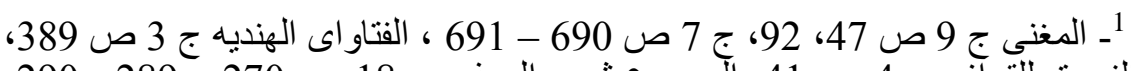

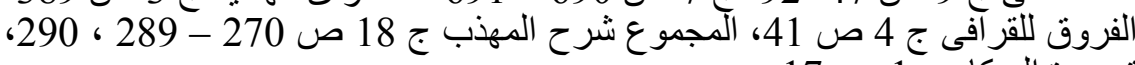
تبصرة الحكام ج 1 ص لـ 17 


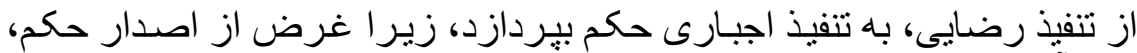

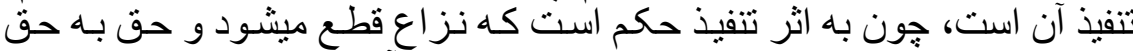

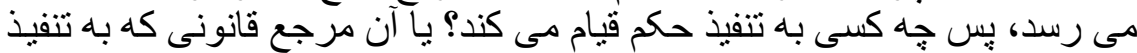

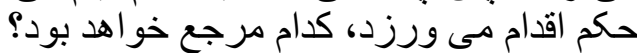

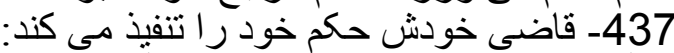

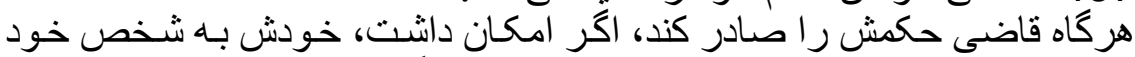

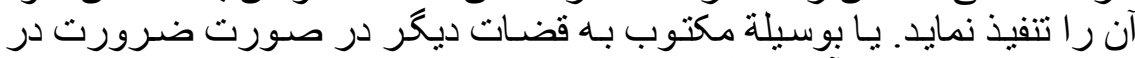

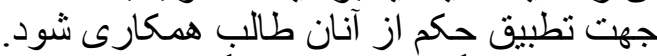

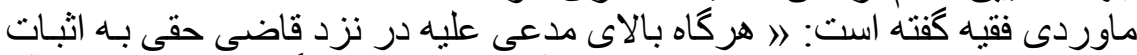

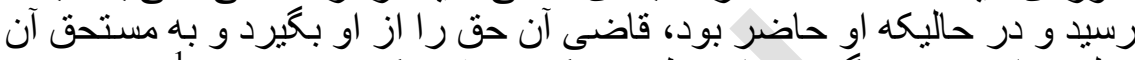

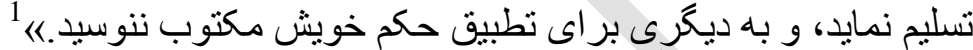

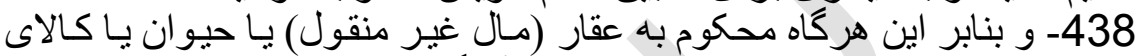

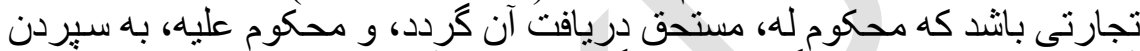

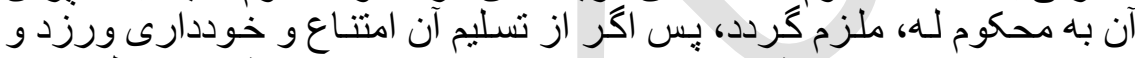

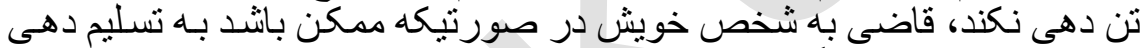

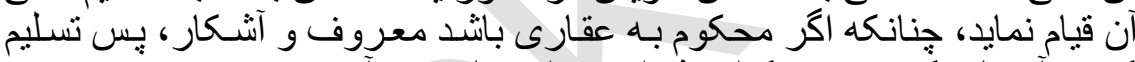

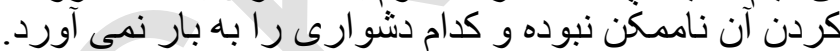

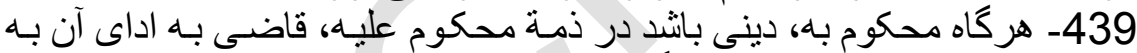

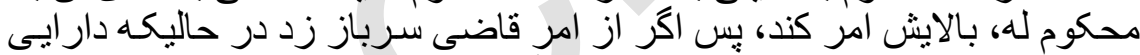

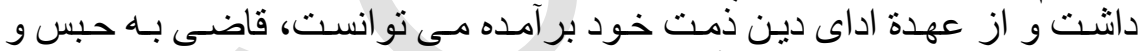

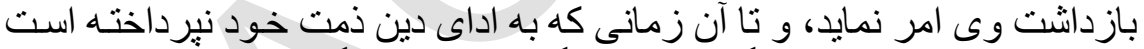

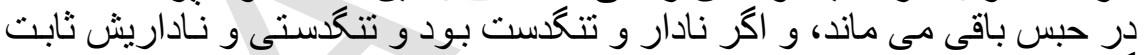

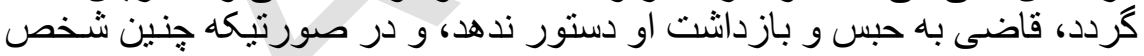

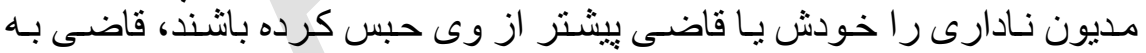

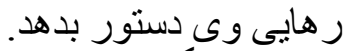

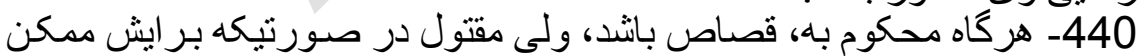

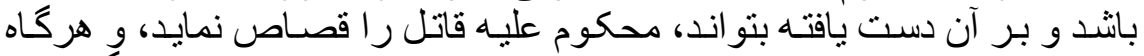

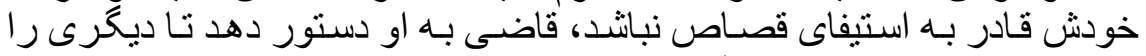

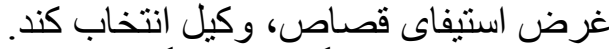

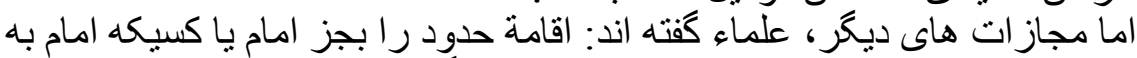

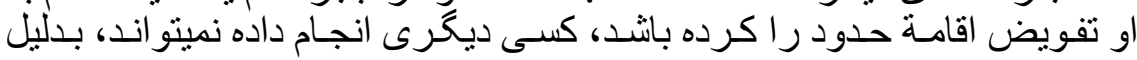

ــ ادب القاضى اللماوردى ج 1 ص 149 


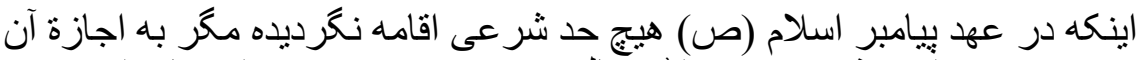

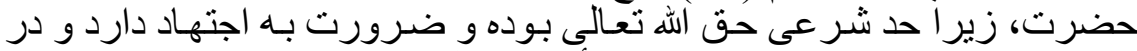

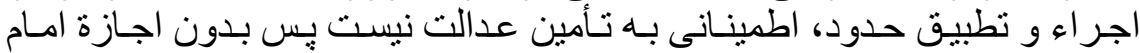

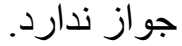

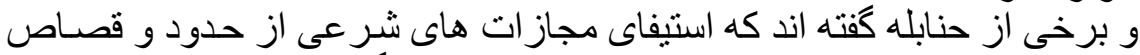

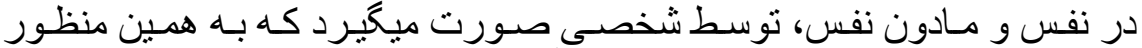

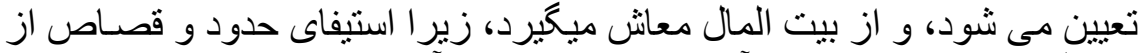

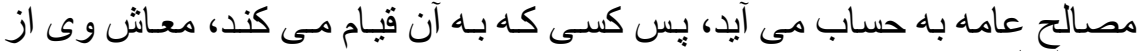

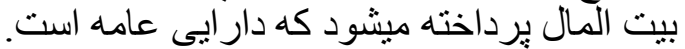

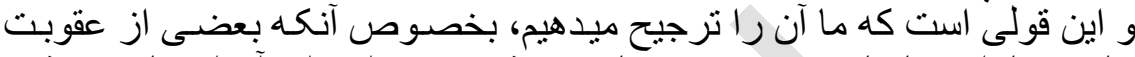

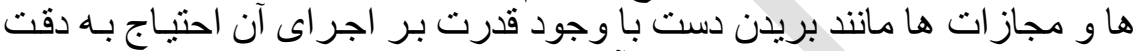

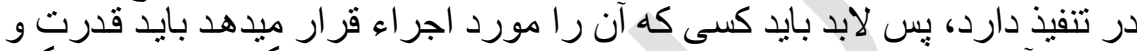

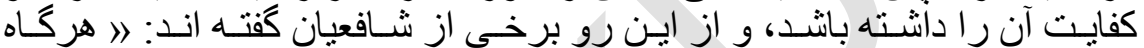

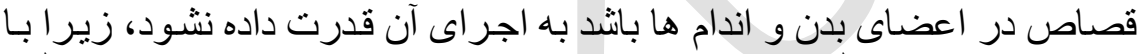

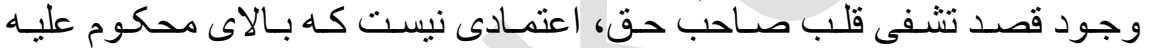

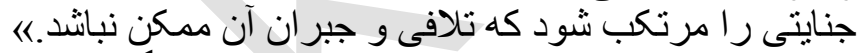

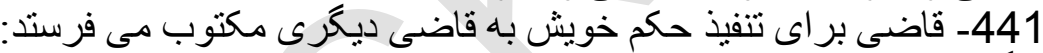

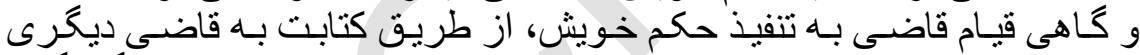

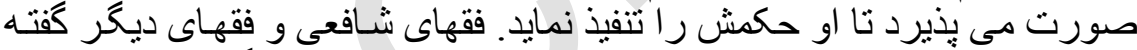

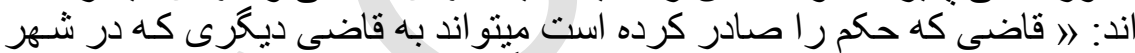

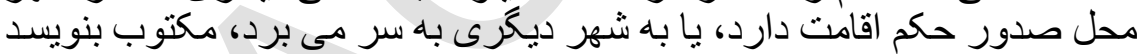

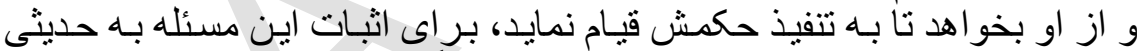

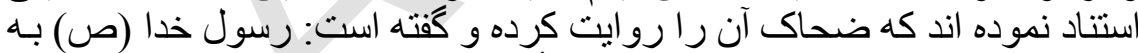

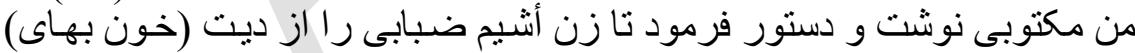

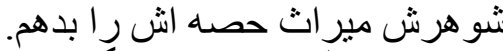

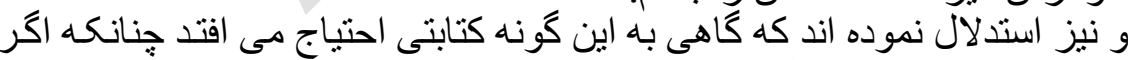

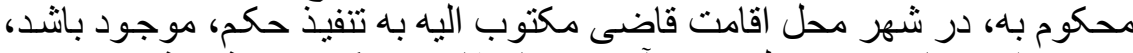

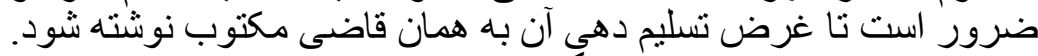

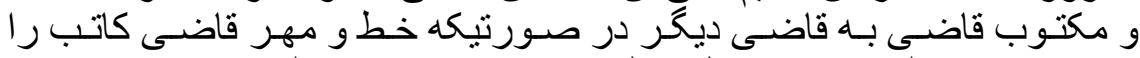

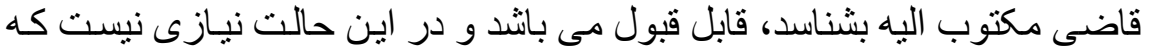


بر ايى اثبات مكتوب قاضي اول طورى كه برخى از فقهاء كفته اند، دو نفر شـاهد

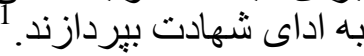

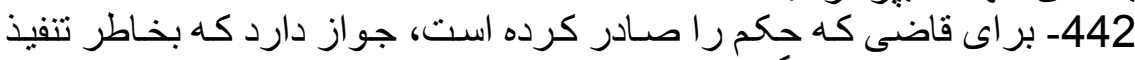

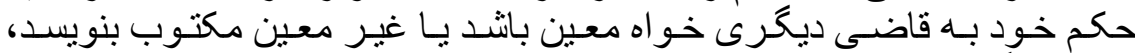

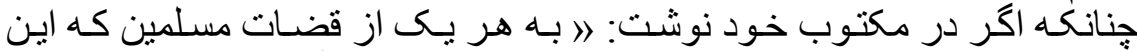

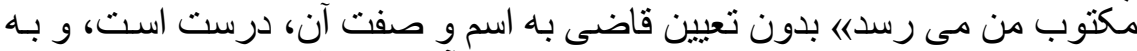

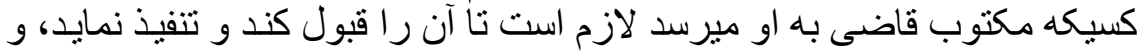

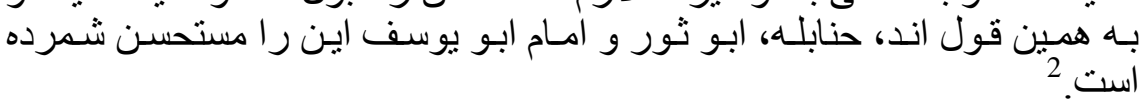

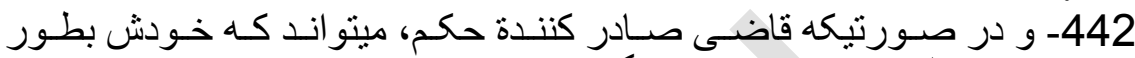

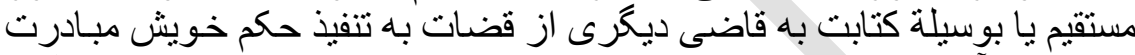

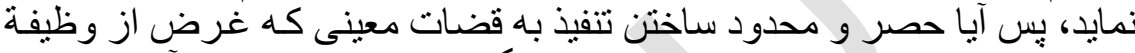

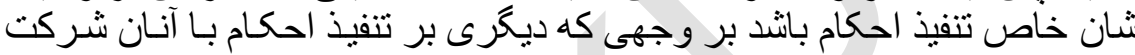

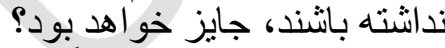

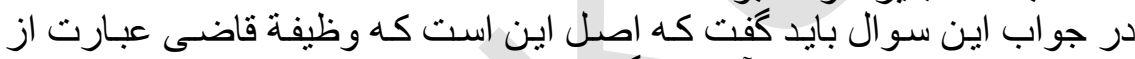

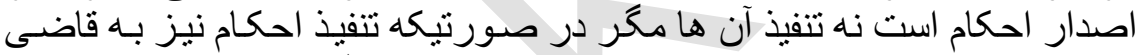

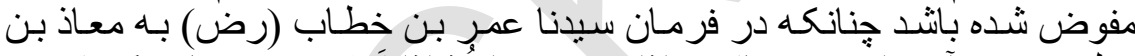

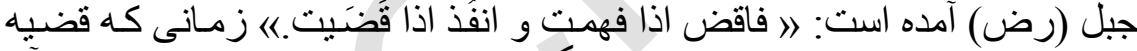

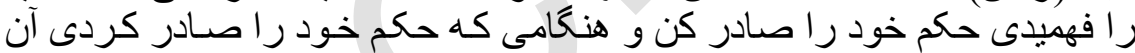

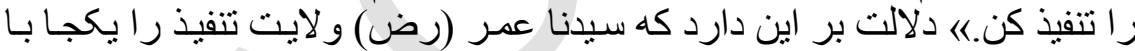

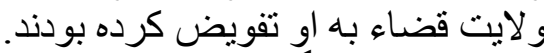

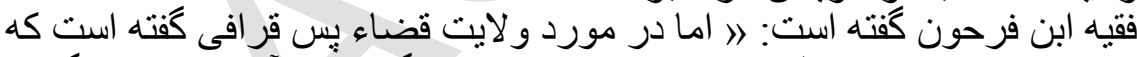

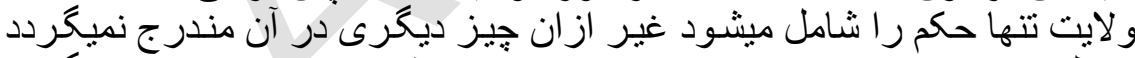

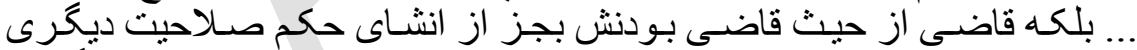

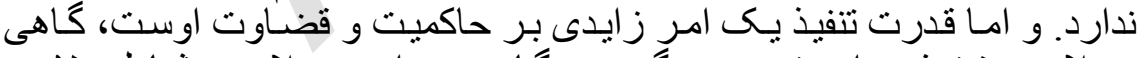

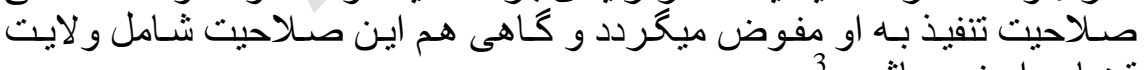

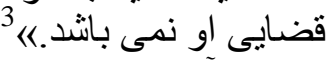

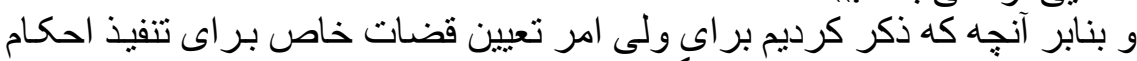

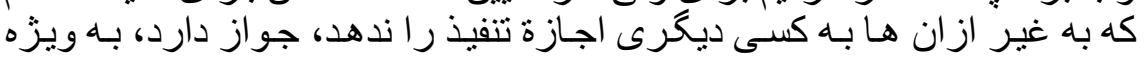

$$
\begin{aligned}
& \text { 1 ـ المجموع ج } 18 \text { ص } 399 \text { - } 394 \text { - } 400 \\
& \text { 2ـ المغنى ج } 9 \text { ص ج } 94 \text { - } 96 \\
& \text { 3ـ ابن فرحون ج } 1 \text { ص ص صل } 17
\end{aligned}
$$


آنكه قضاء وظيفه يى است كه تخصيص آن به زمان و مكان و نوع خصومت ها

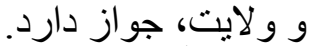

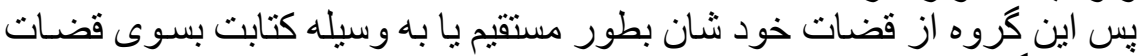

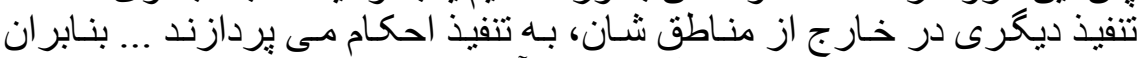

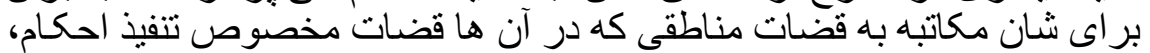

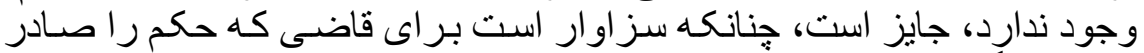

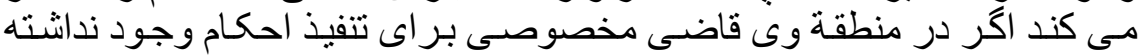

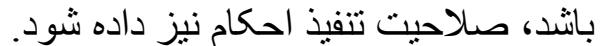

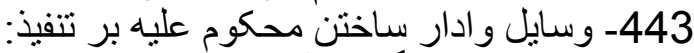

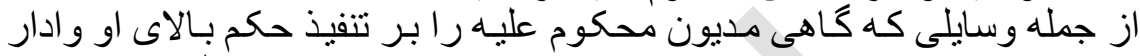

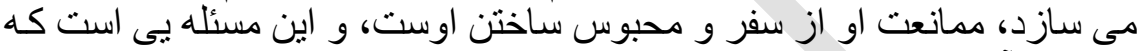
فقهاء بر آن تصريح كرده اند.

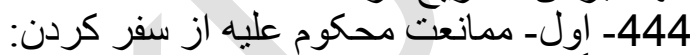

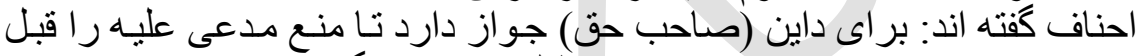

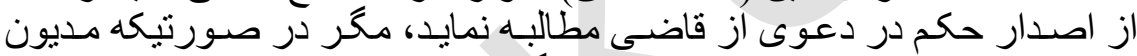

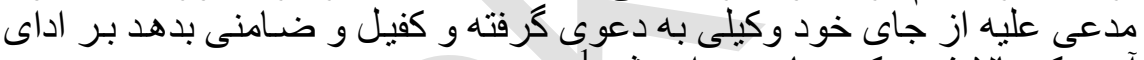

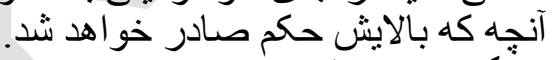

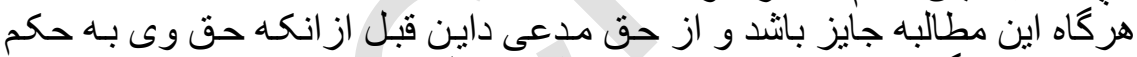

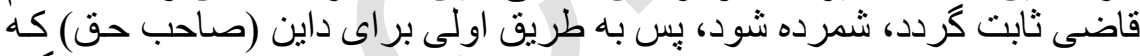

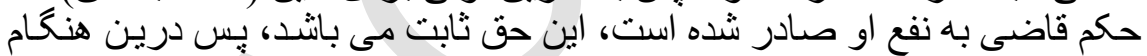

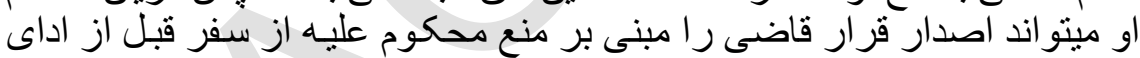
حق محكوم باه، مطالبه نمايد.

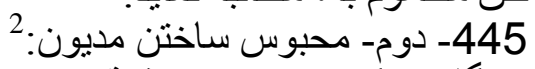

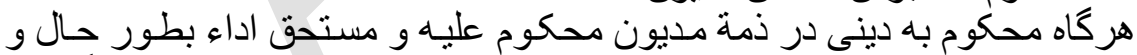

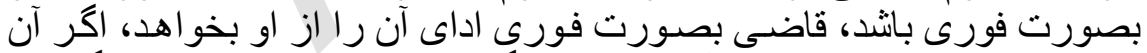

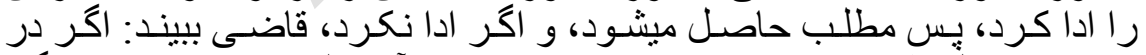

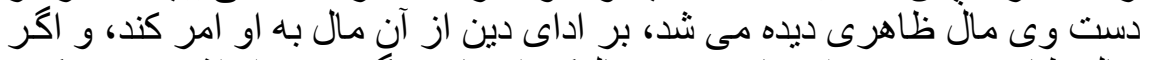

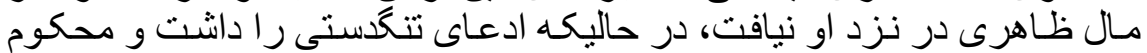

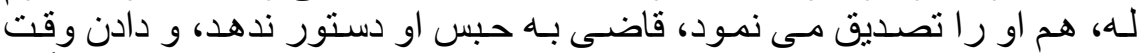

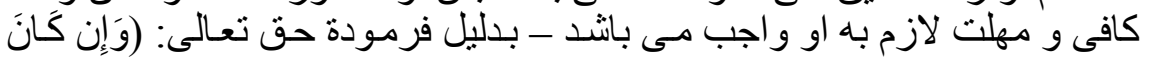

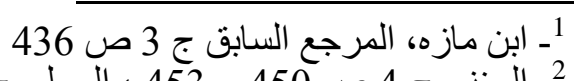

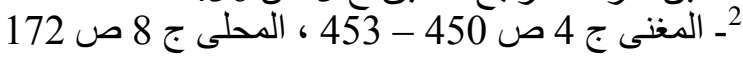




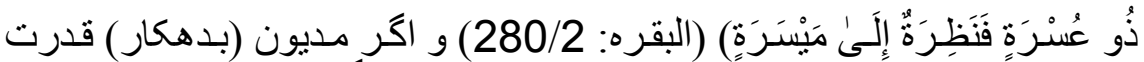

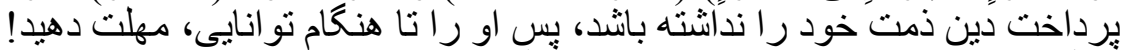

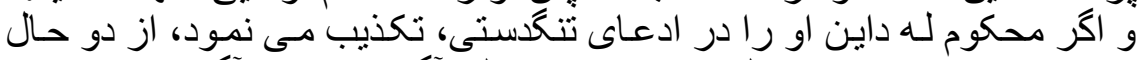

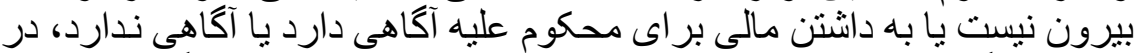

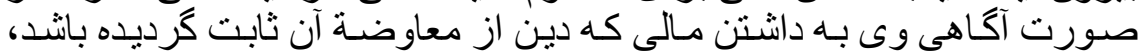

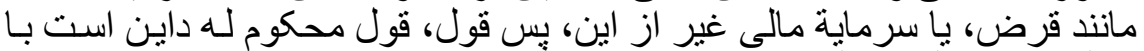

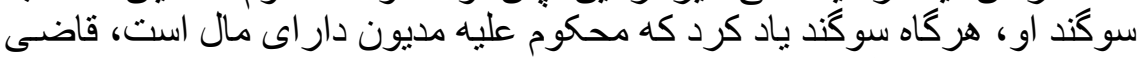

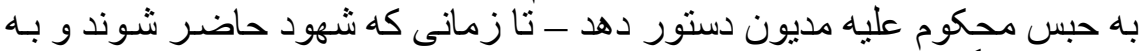

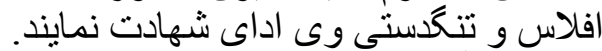

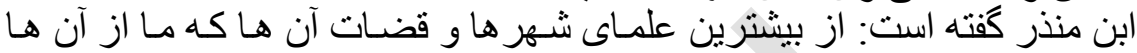

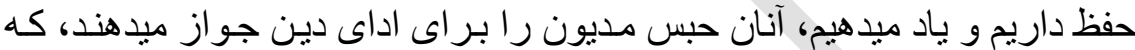

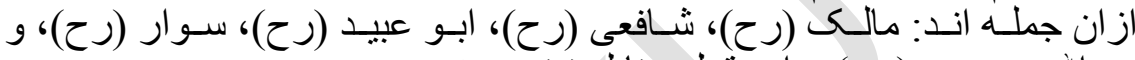

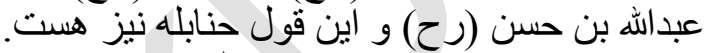

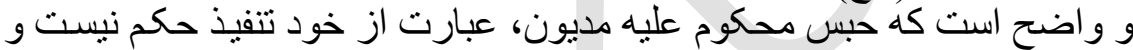

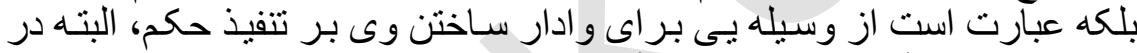

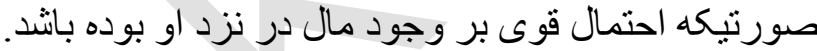

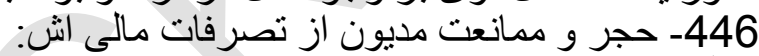

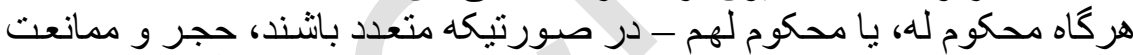

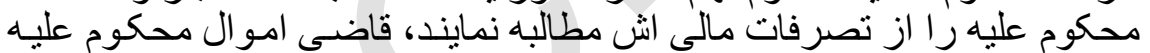

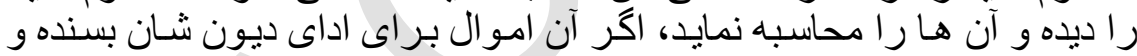

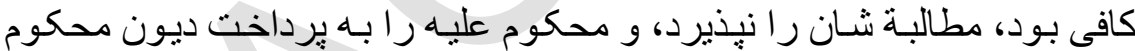

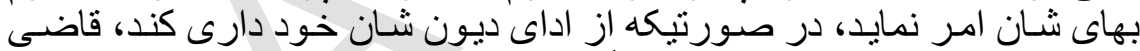

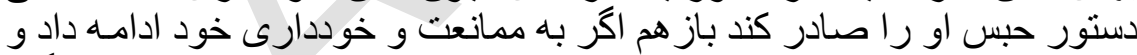

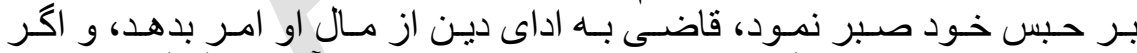

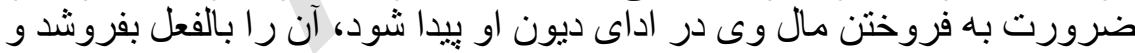

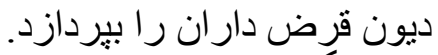

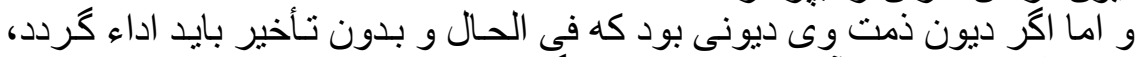

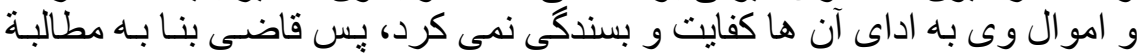

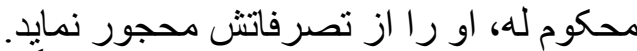

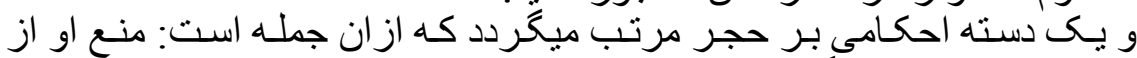

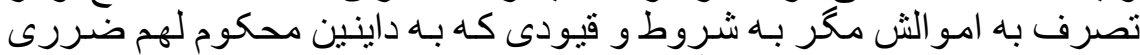

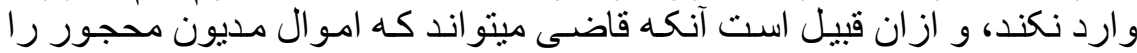

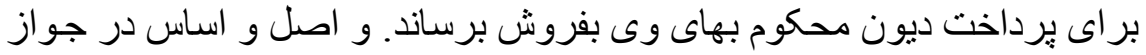




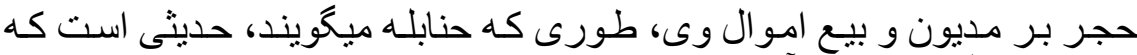

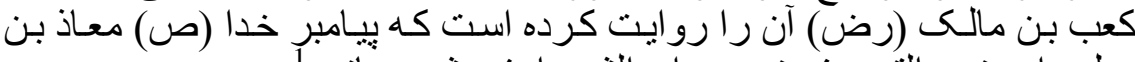

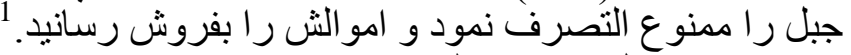
447- بيع اموال محنوع التهرف عليه مديون:

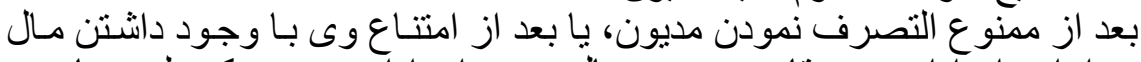

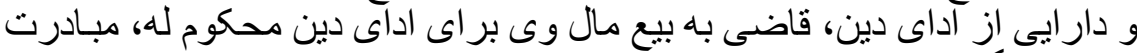

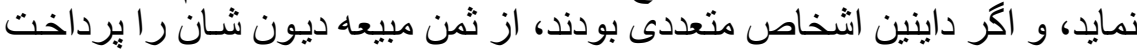

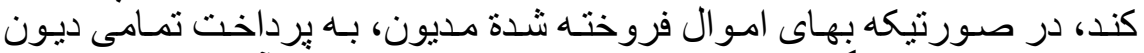

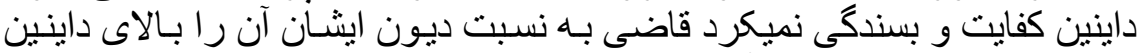

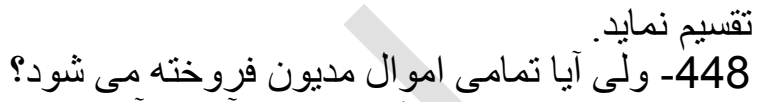

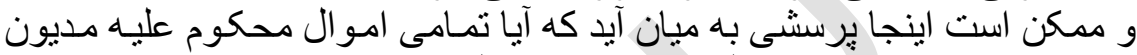

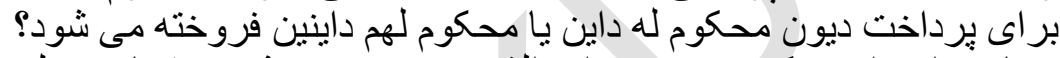

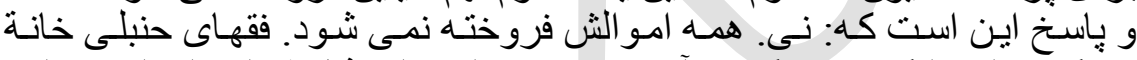

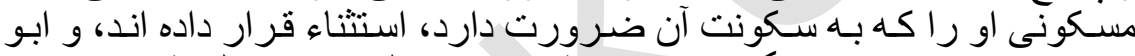

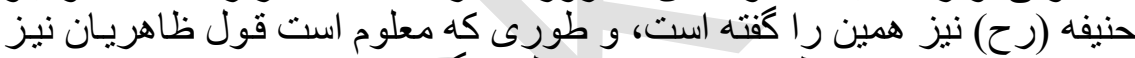

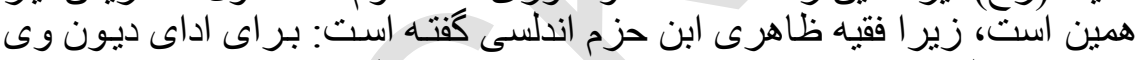

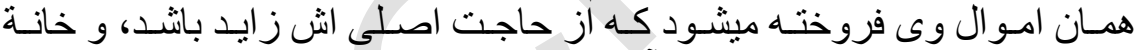

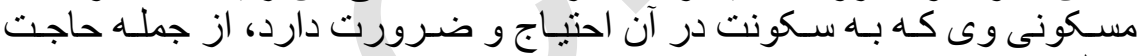

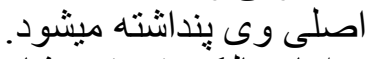

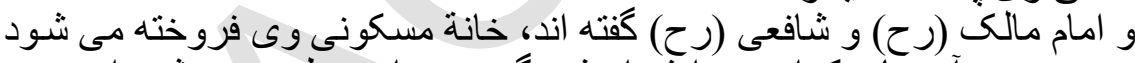

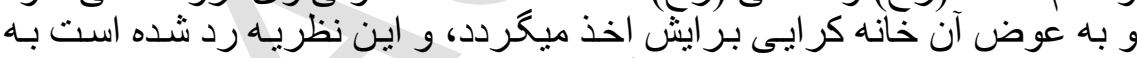

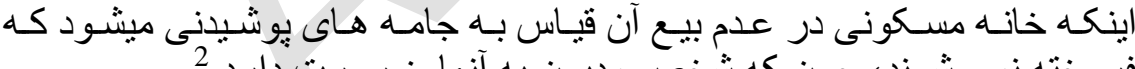

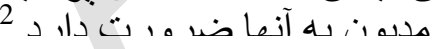

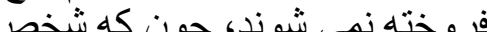

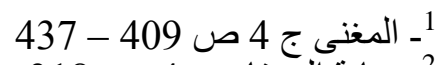

2ـ نهاية المحتاج ج 4 ص ص 318 ـ 437 ، المحلى ج 4 ص 409 ، 442 - 445 ، المحلى ج 8

ص 174 
قضاوتيوه حضرت كل حسامى

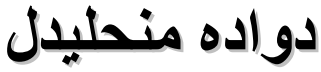 \\ او دهغه يايلى دمدنى قاتون اوشريعث لله نظره

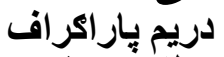 \\ دطلاق دولونه دئه}

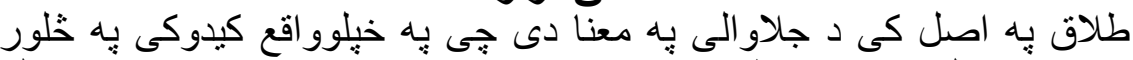

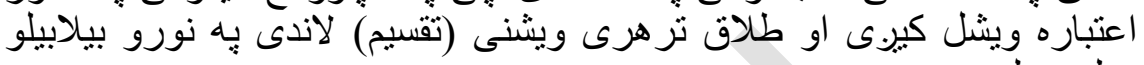
جولونوبيليزى : اعني

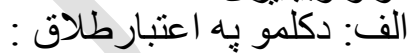

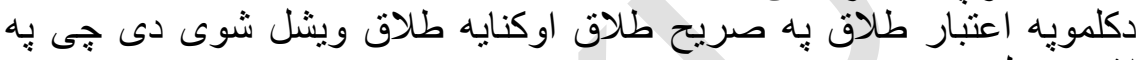
لاندى دول ديه اعنيار :

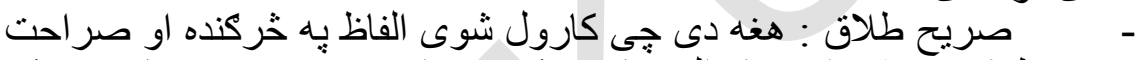

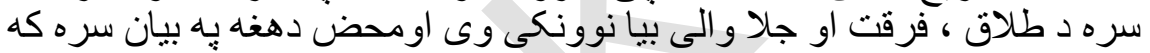

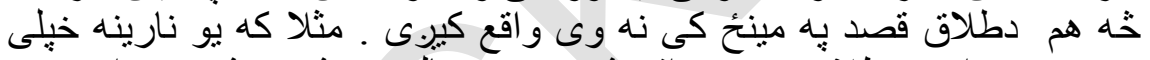

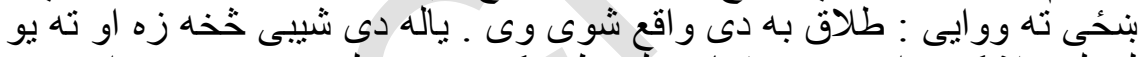

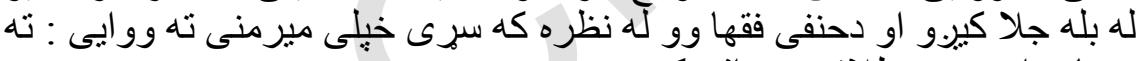

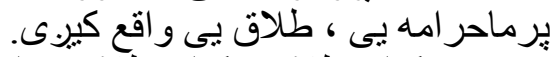

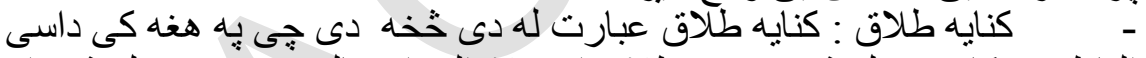

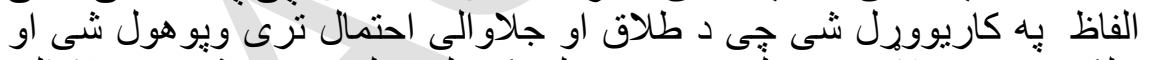

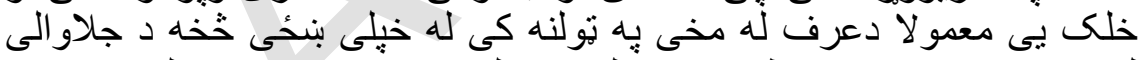

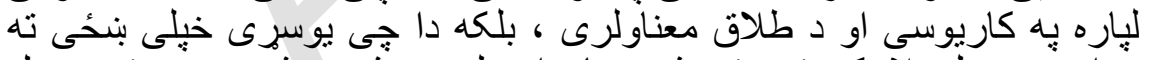

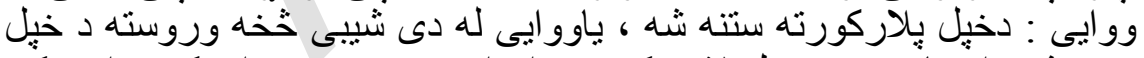

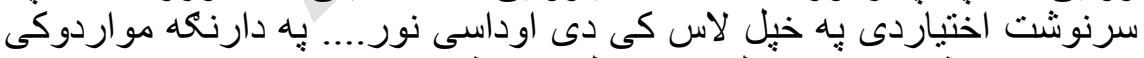

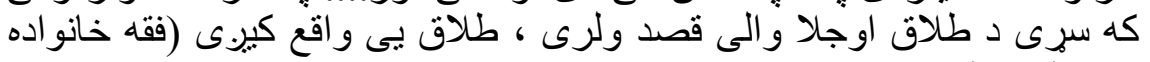

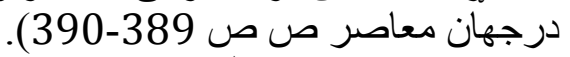

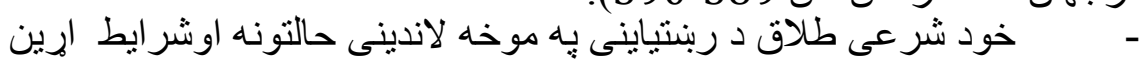

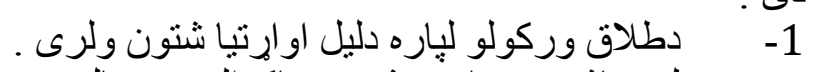

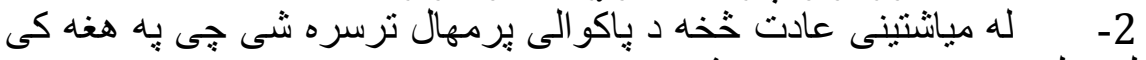

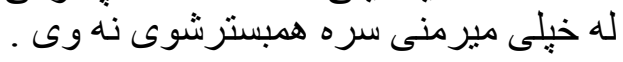




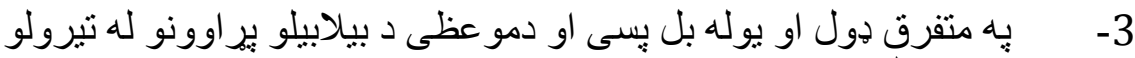

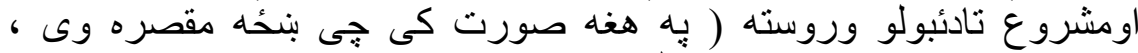

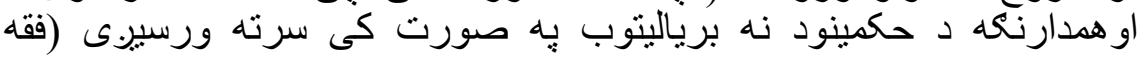

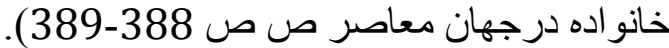

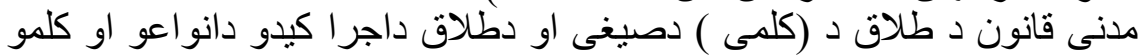

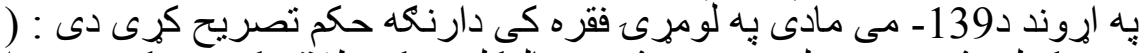

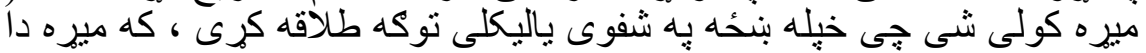

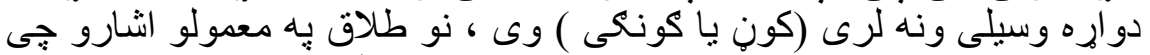

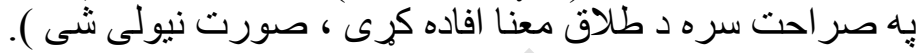

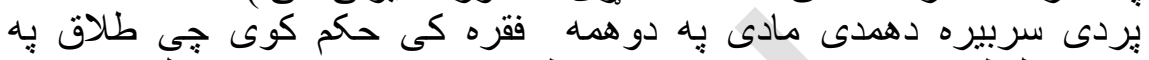

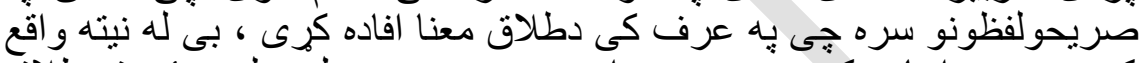

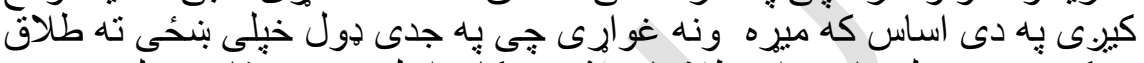

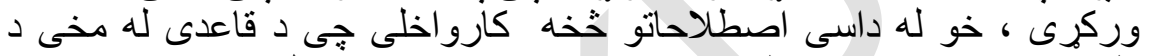

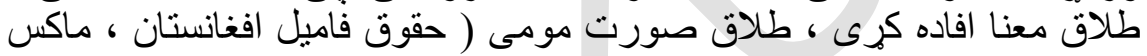

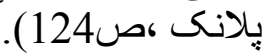

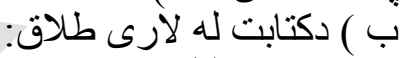

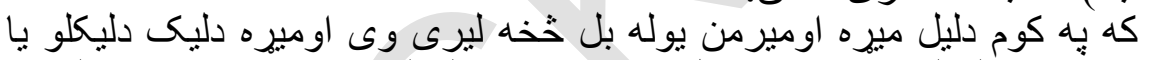

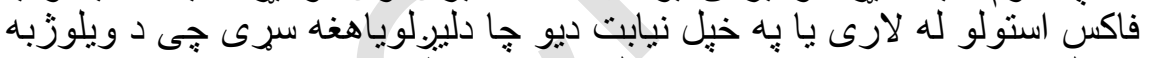

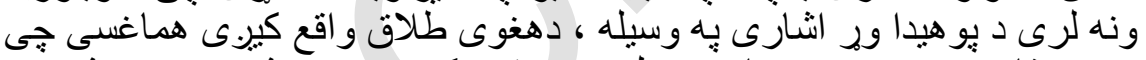

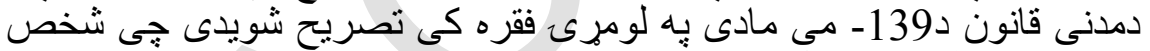

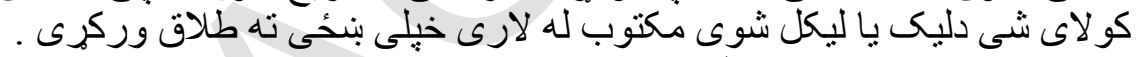

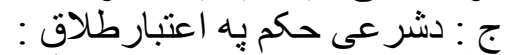

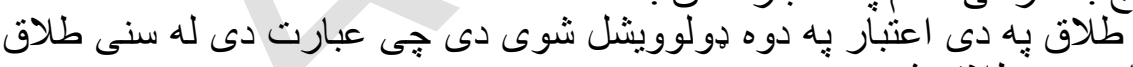

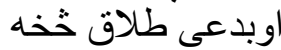

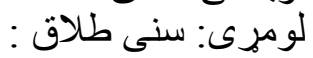

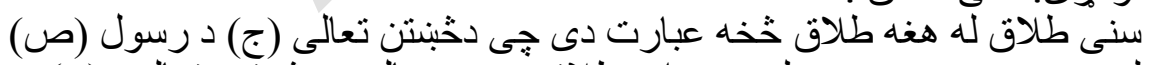

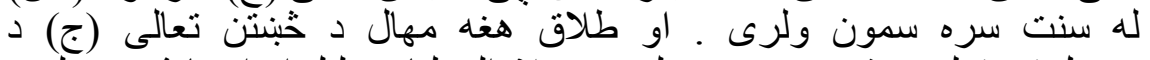

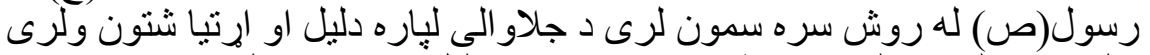

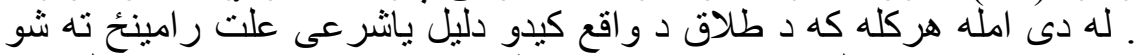

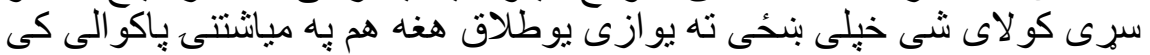

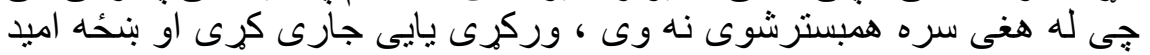

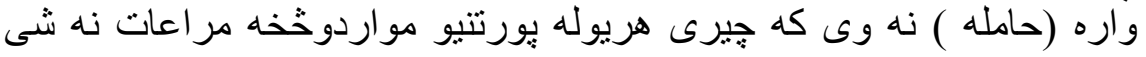


طلاق ، بدعى دى او جارى كول يى جايزندى او ترسره كوونكى يى

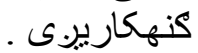

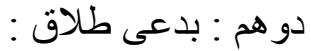

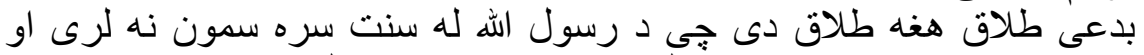

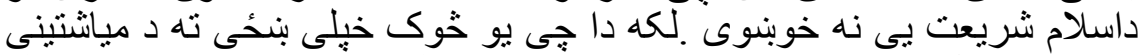

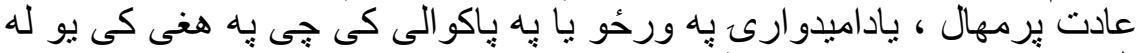

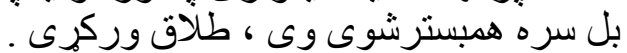

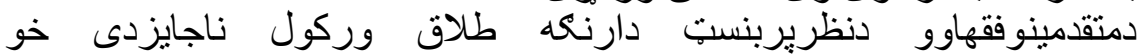

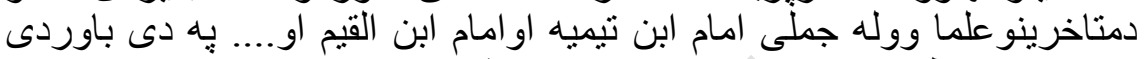

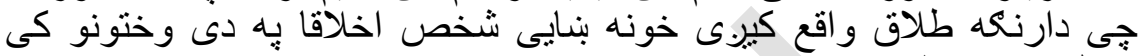

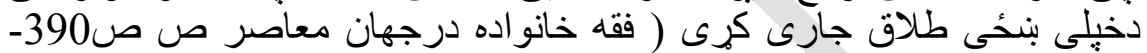

د: طلاق د و اقع كيدو اونه و اقع كيدوله نظره :

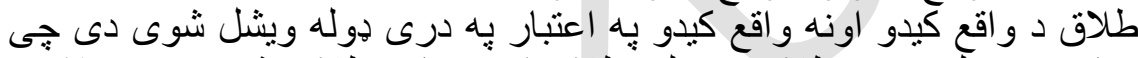

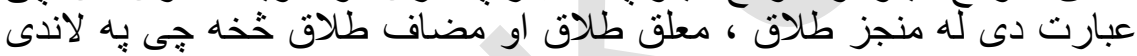

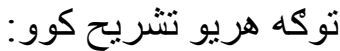

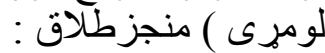

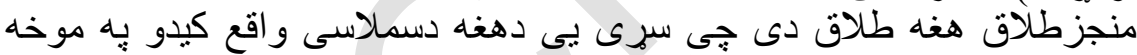

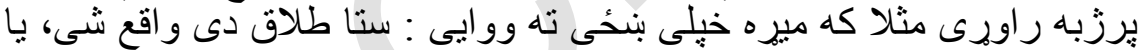

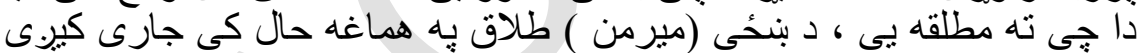

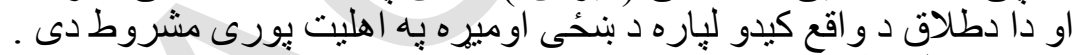

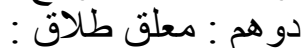

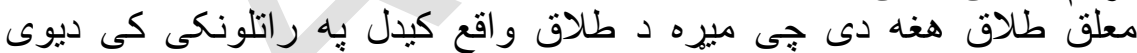

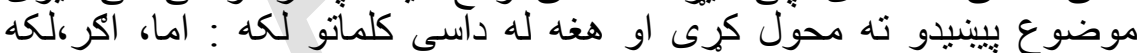

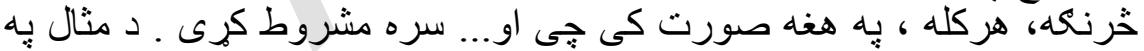

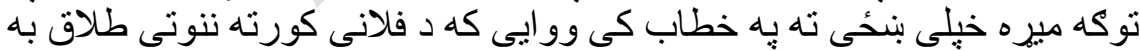

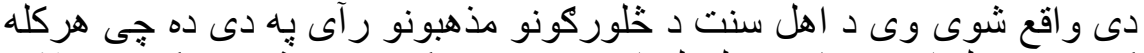

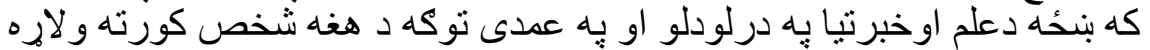

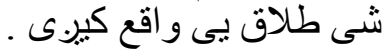
دريم : مضاف طلاف وقلاق : ميرى

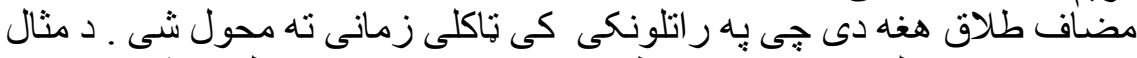

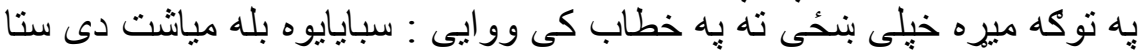

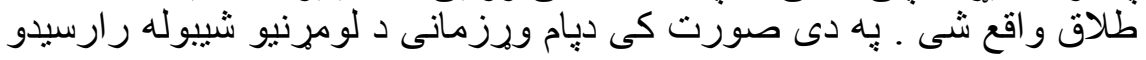




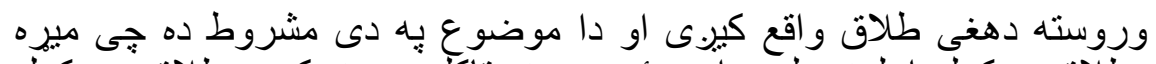

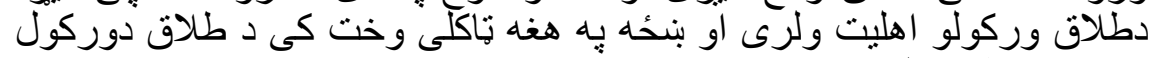

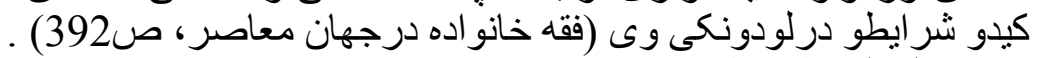

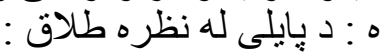

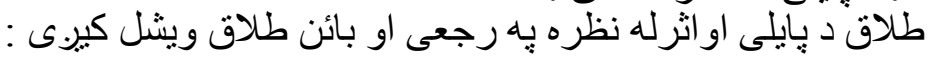

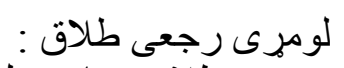

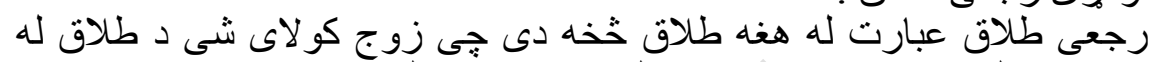

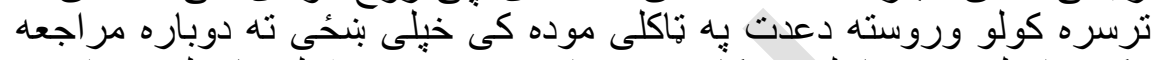

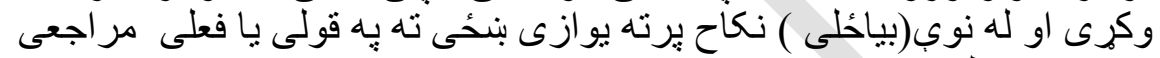

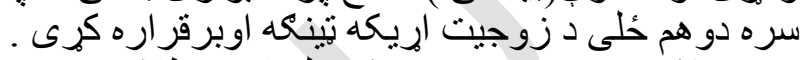

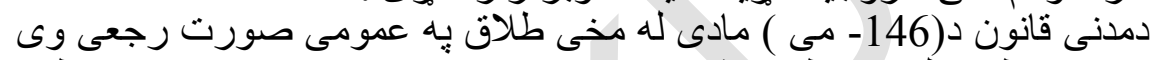

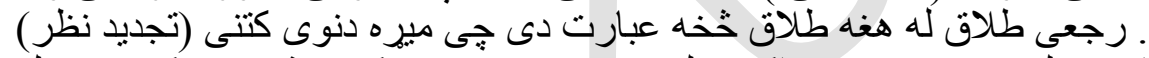

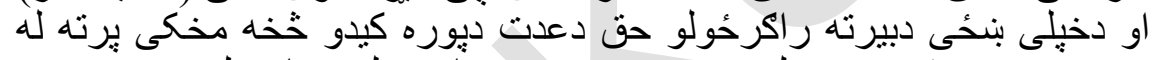

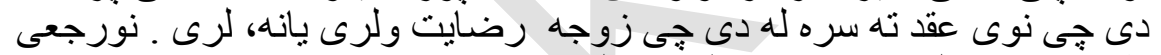

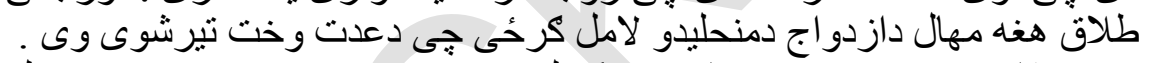

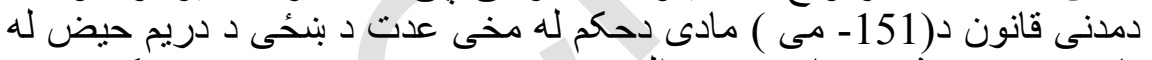

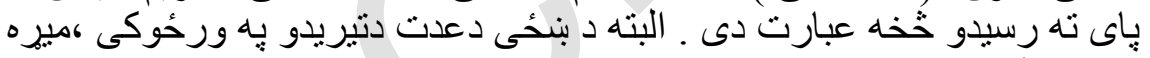

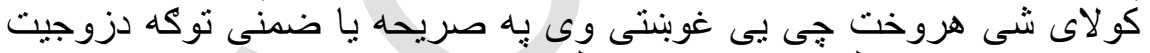

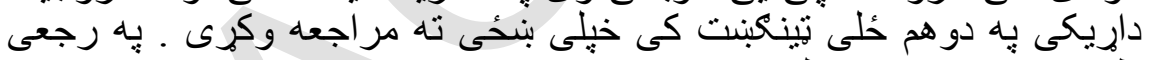

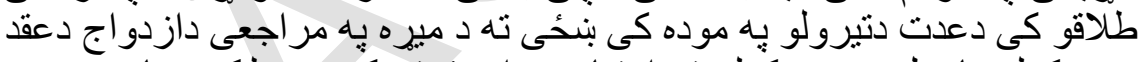

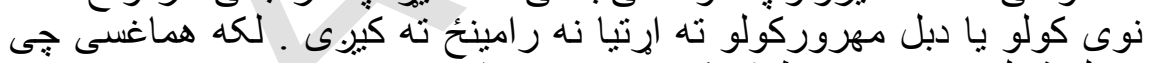

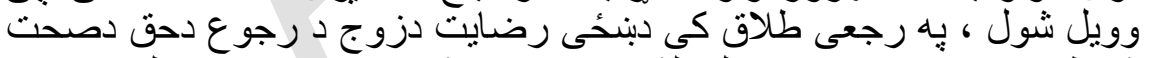

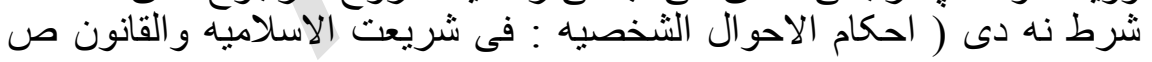
صنا289-280).

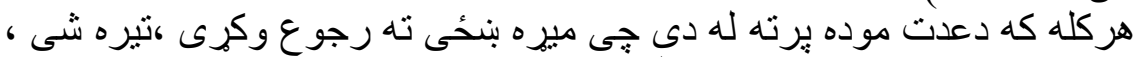

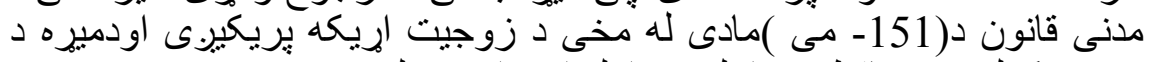

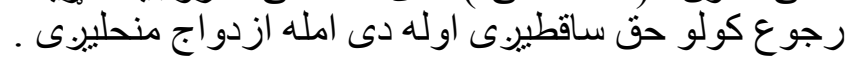

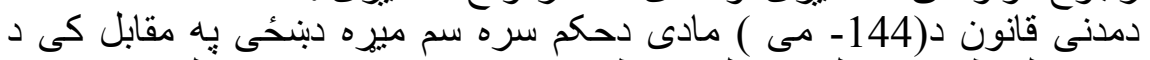

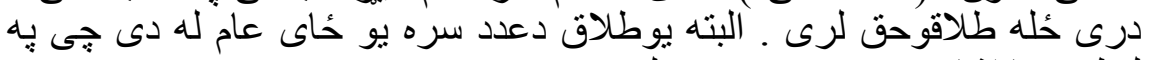

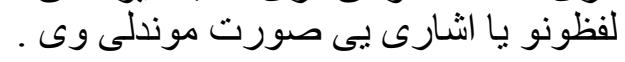




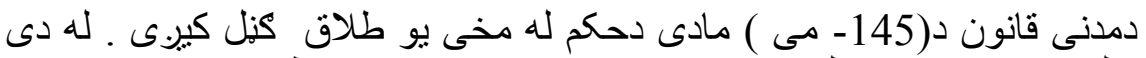

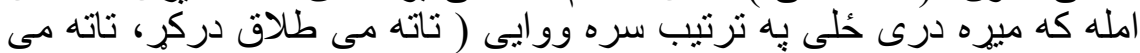

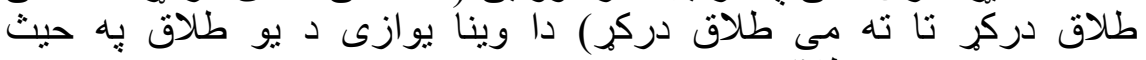

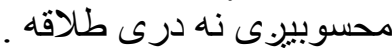

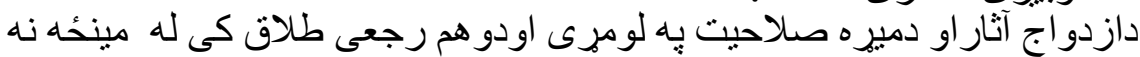

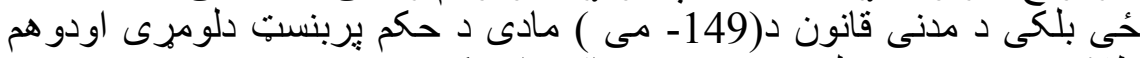

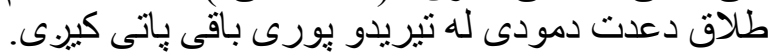

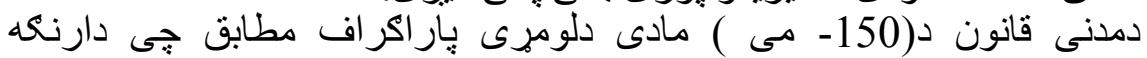

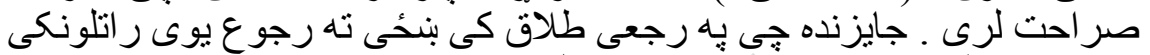

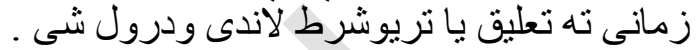

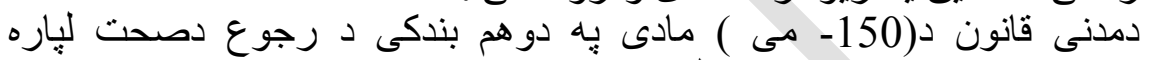

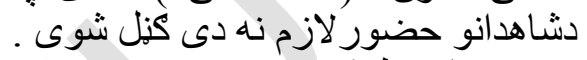

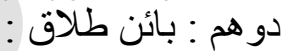

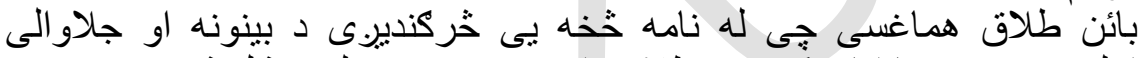

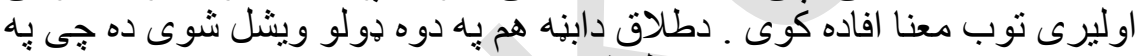

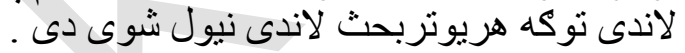

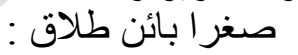

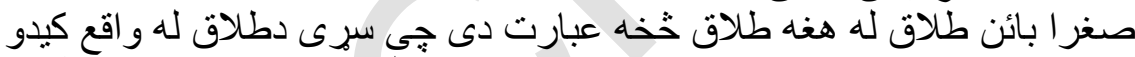

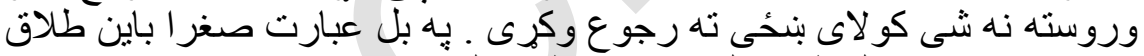

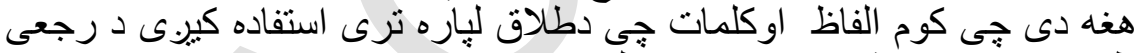

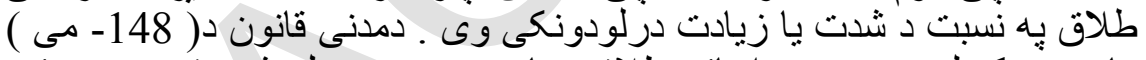

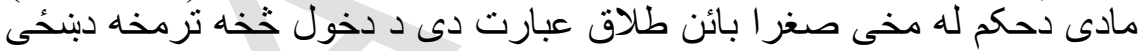

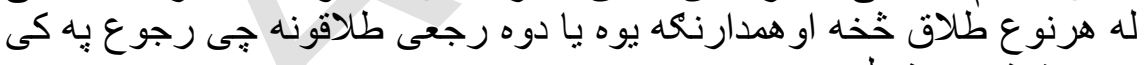

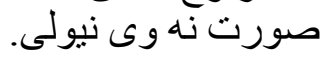

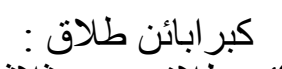

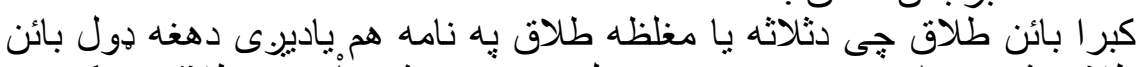

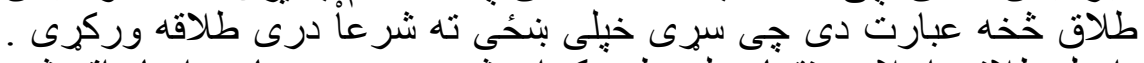

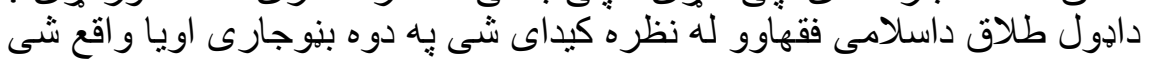

$$
\text { -1 }
$$




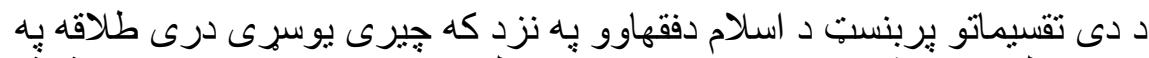

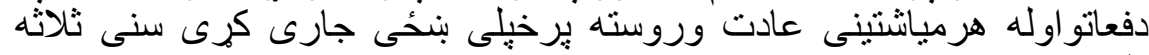

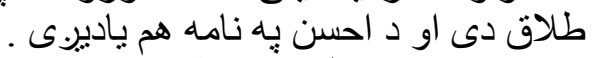

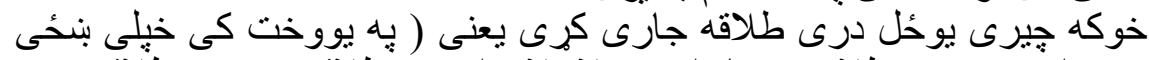

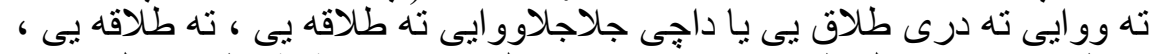

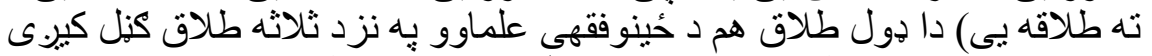

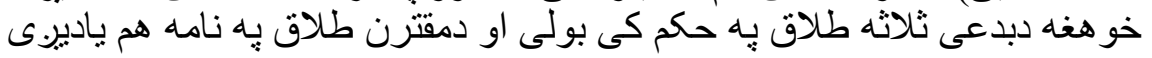

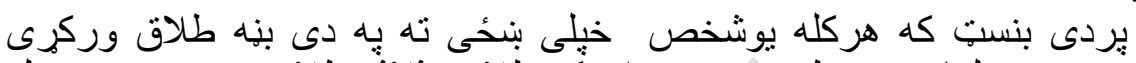

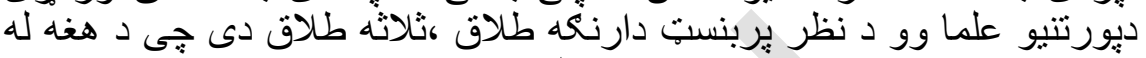

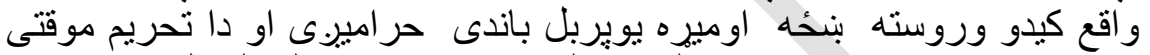

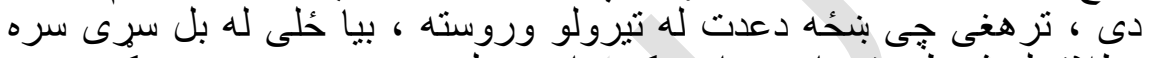

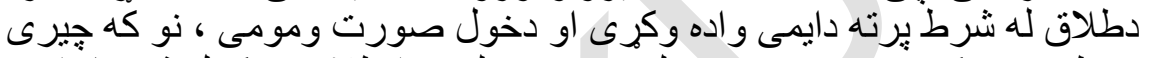

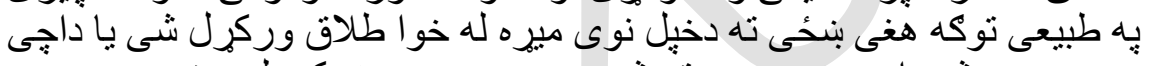

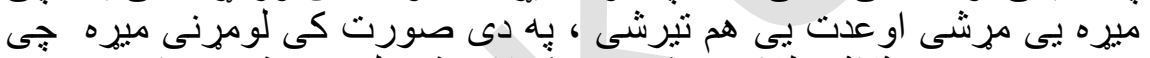

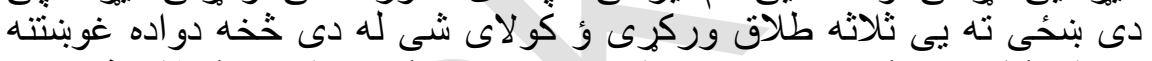

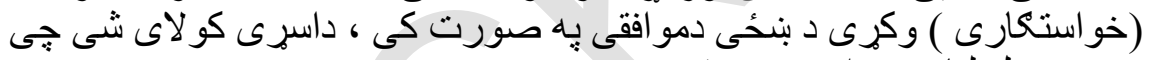

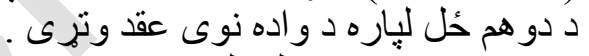

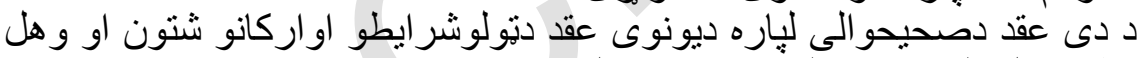

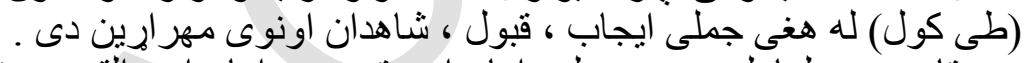

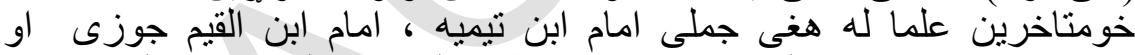

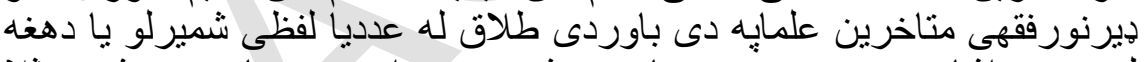

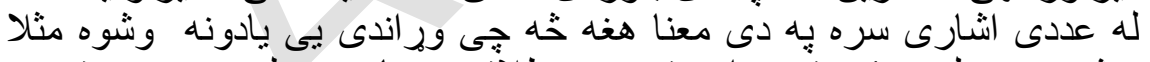

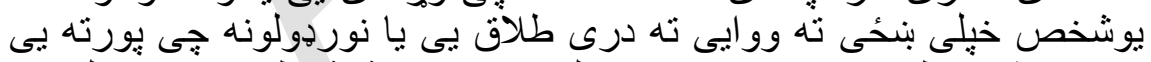

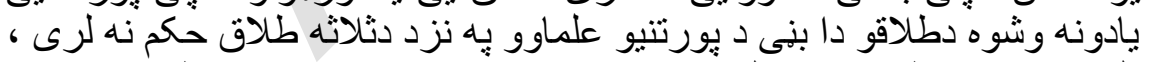

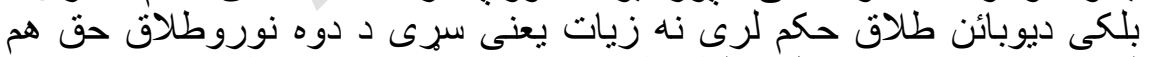

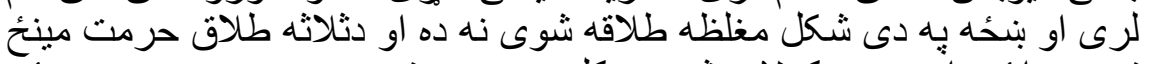

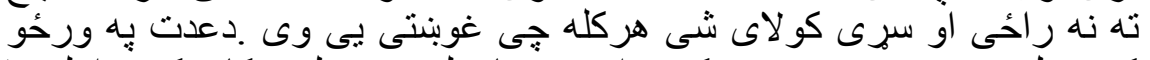

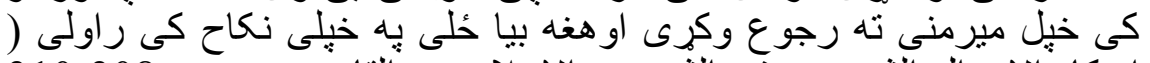

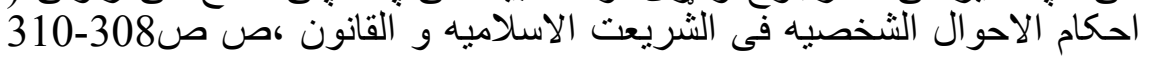

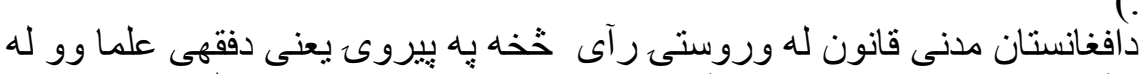

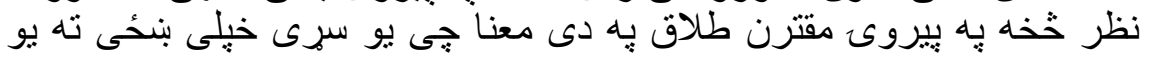




\section{دواده منحليدل}

قُخايو

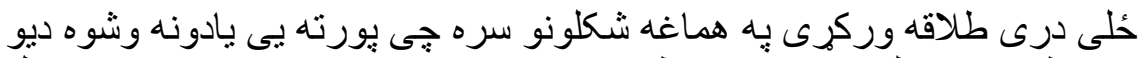

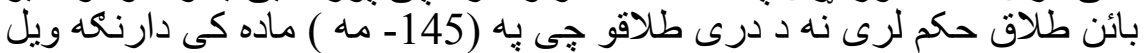

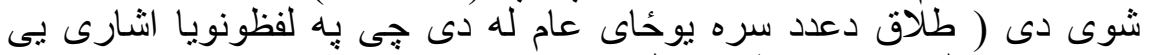

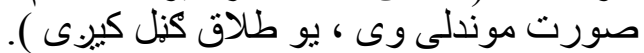

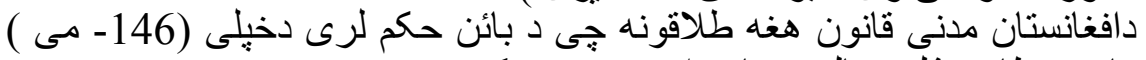

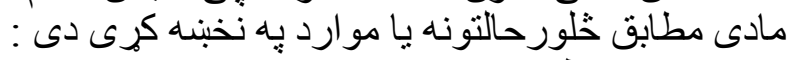

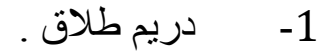

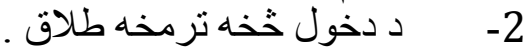

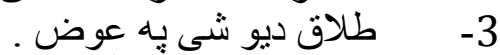

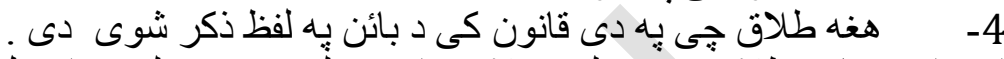

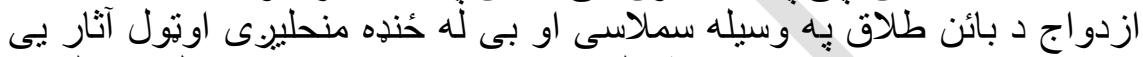

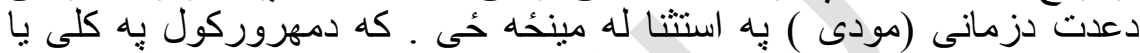

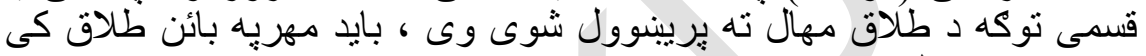

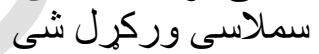

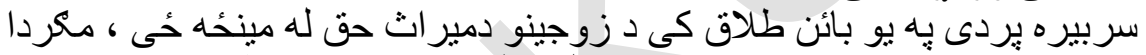

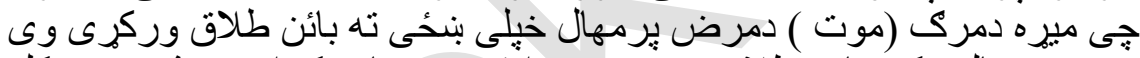

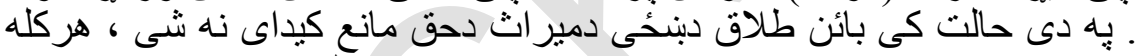

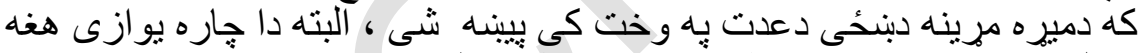

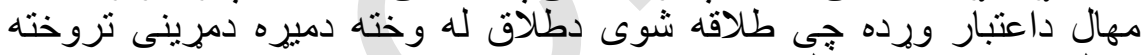

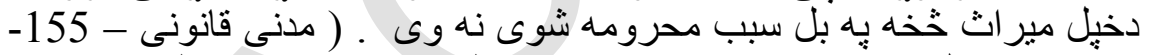

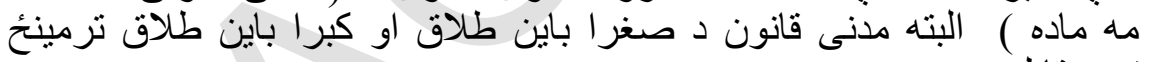

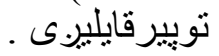

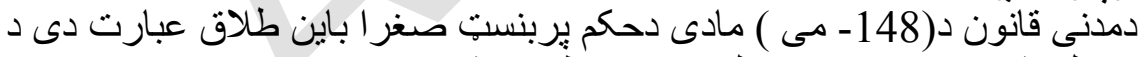

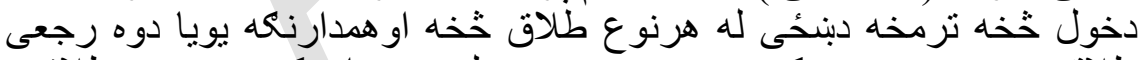

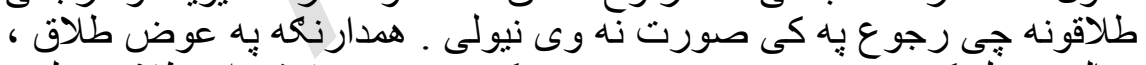

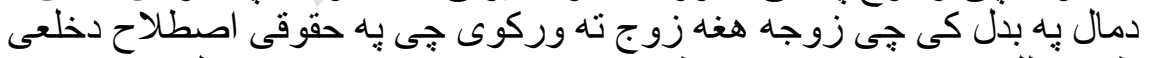

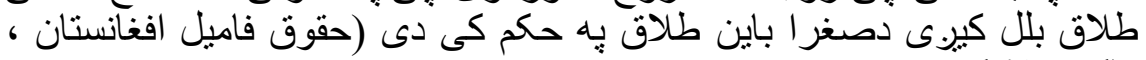

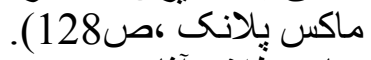

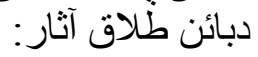

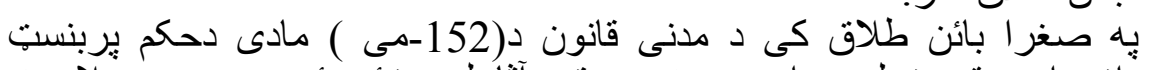

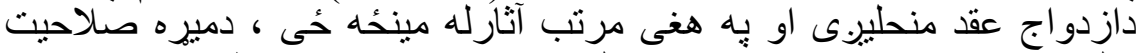

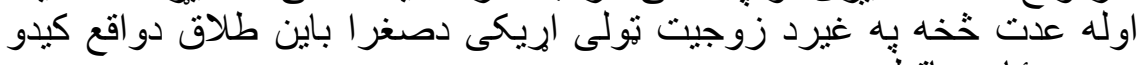

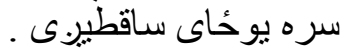




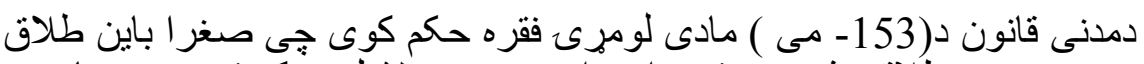

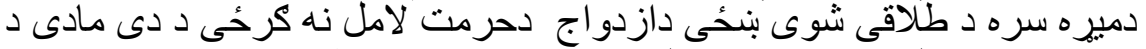

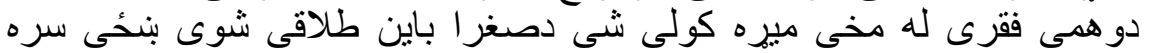

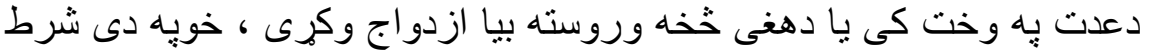

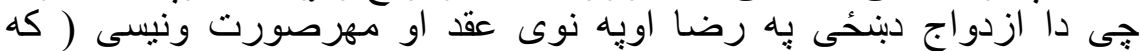

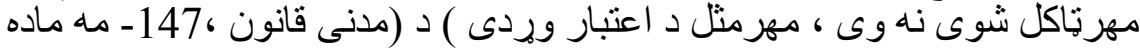

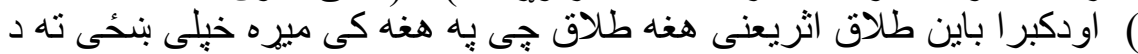

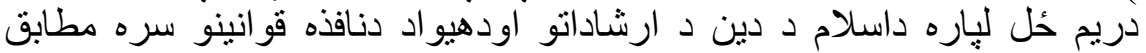

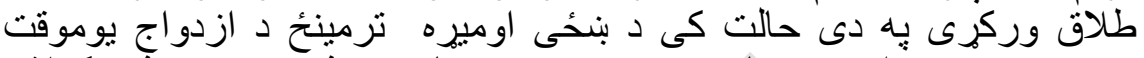

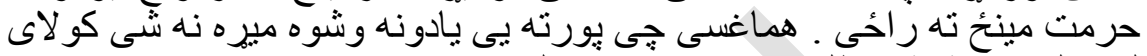

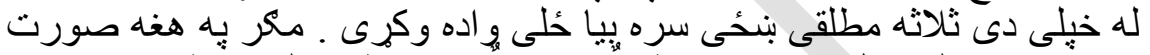

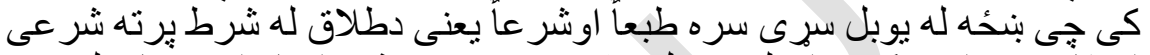

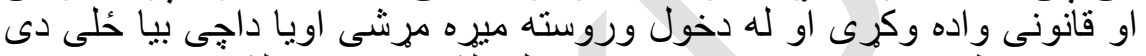

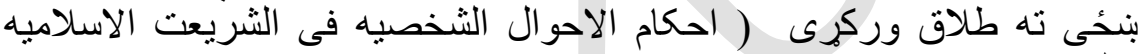

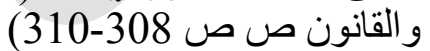

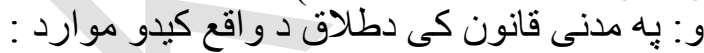

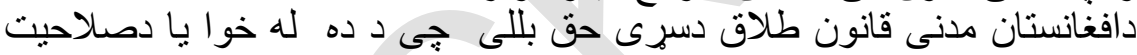

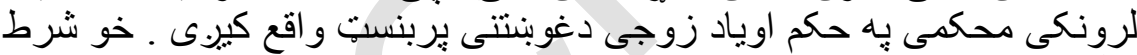

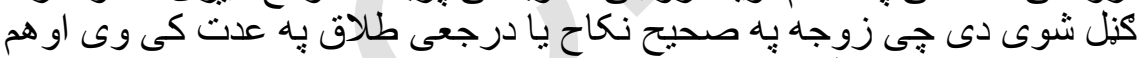

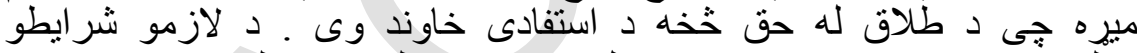

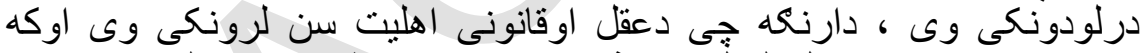

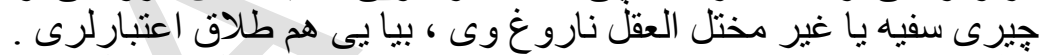

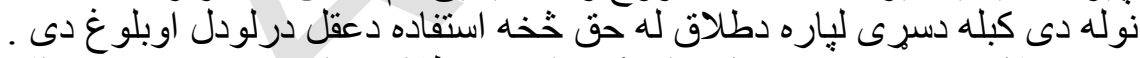

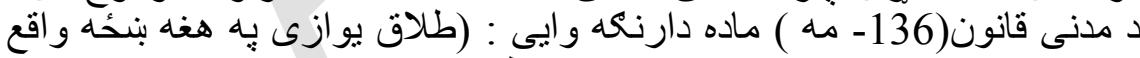

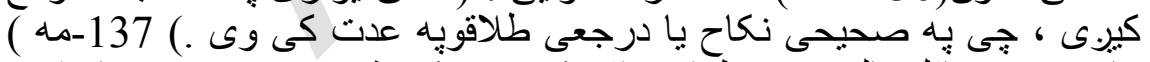

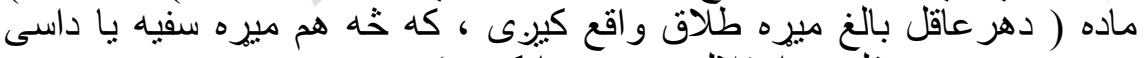

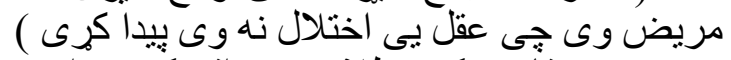

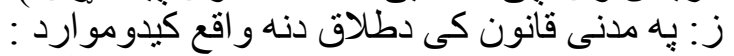

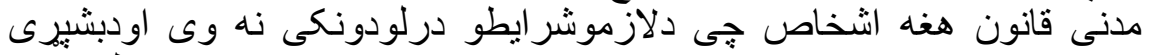

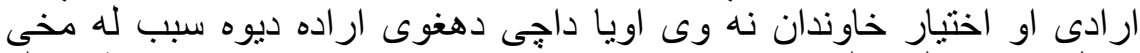

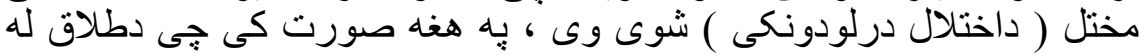

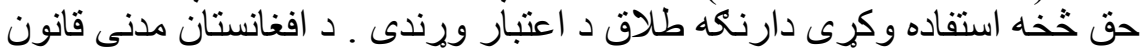

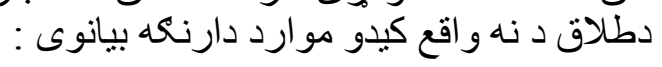




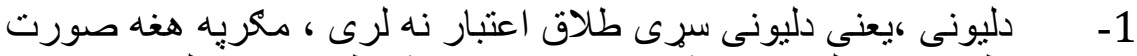

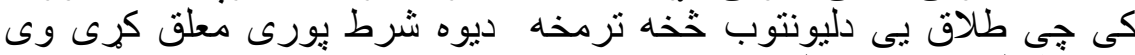

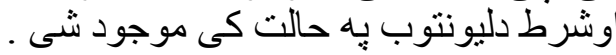
3-

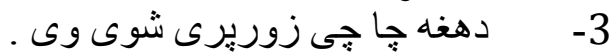

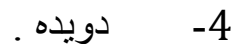

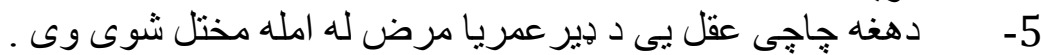

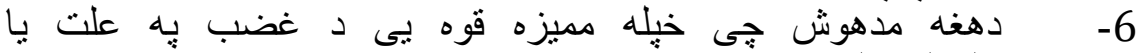

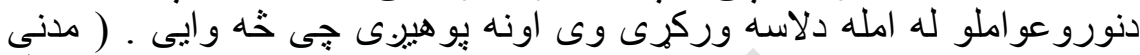

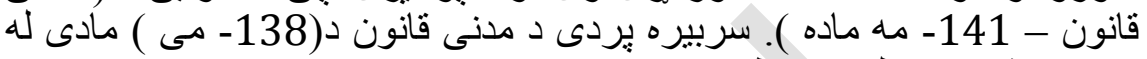

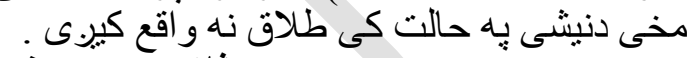

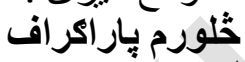

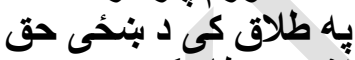

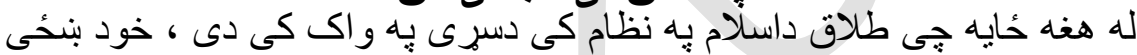

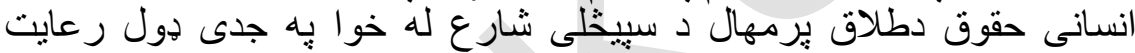

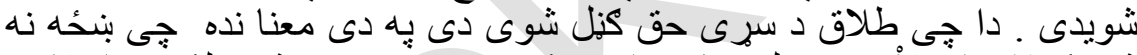

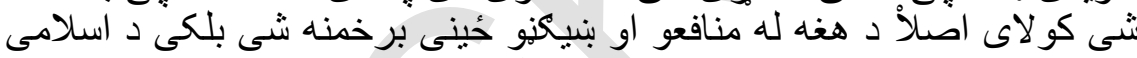

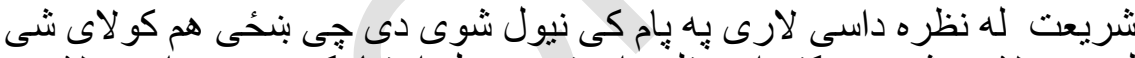

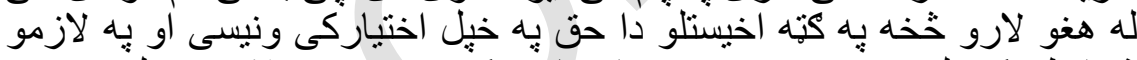

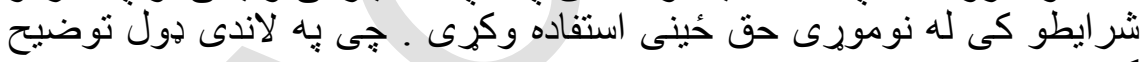

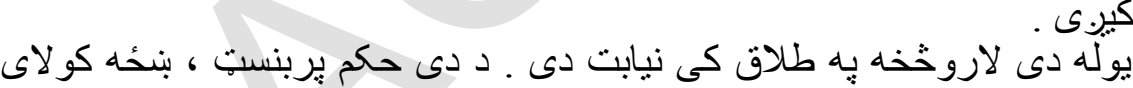

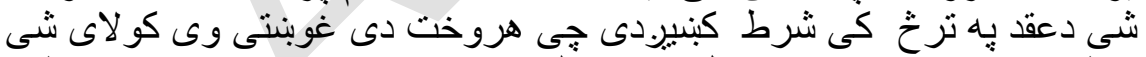

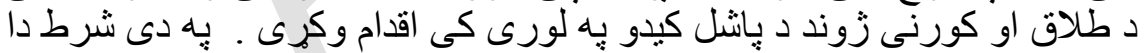

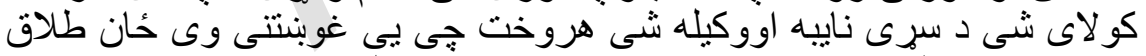

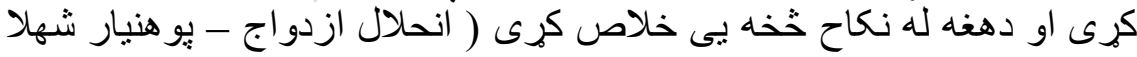

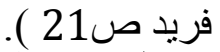

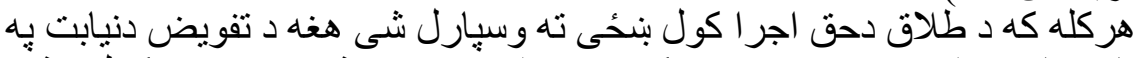

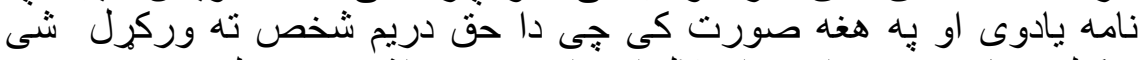

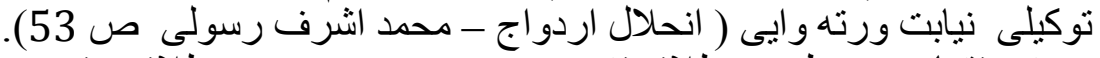

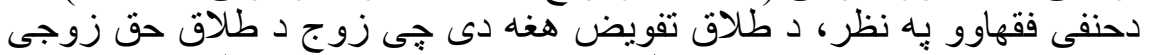

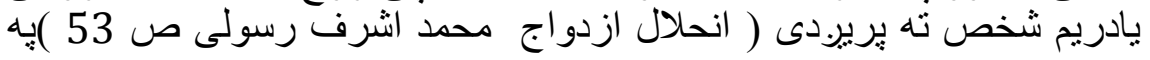




\section{دواده منحليدل}

قُخايو

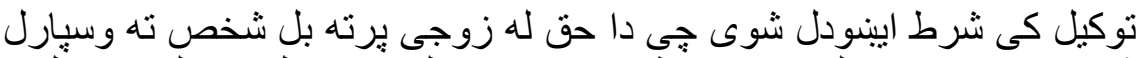

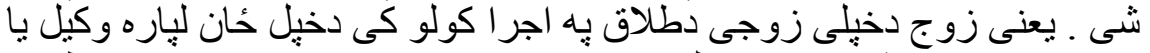

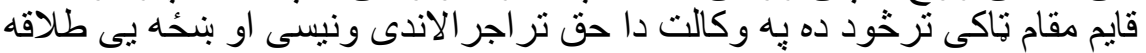
كرى .

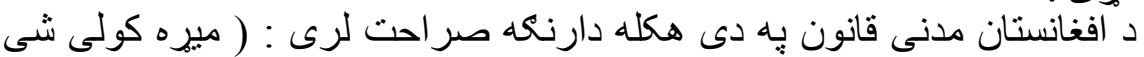

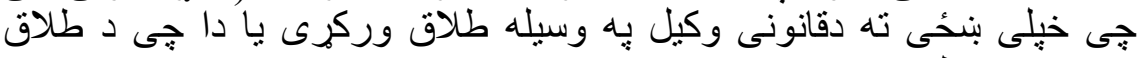

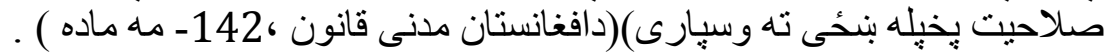

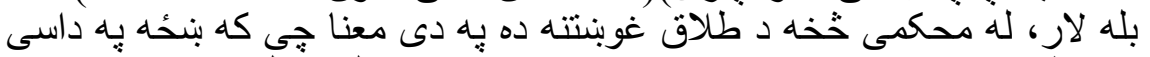

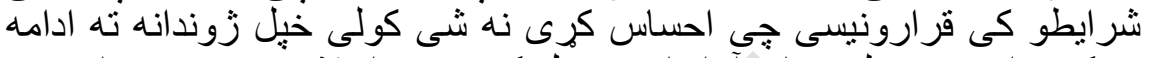

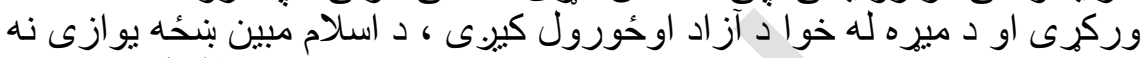

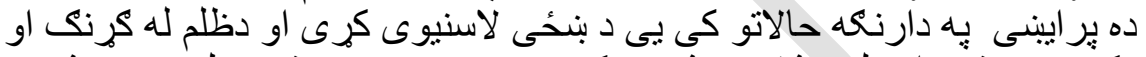

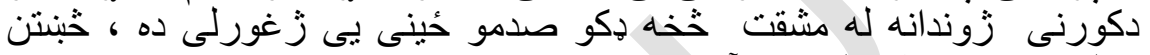

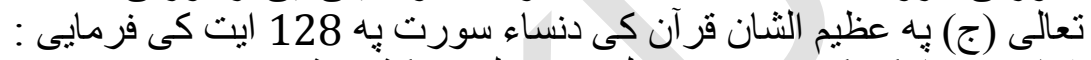

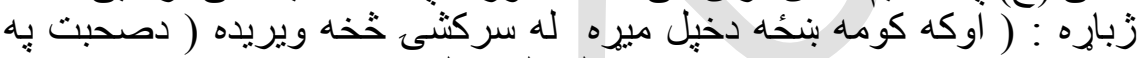

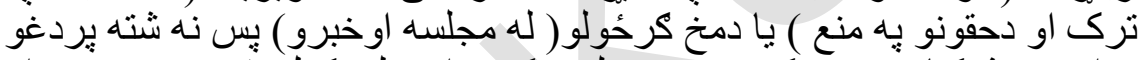

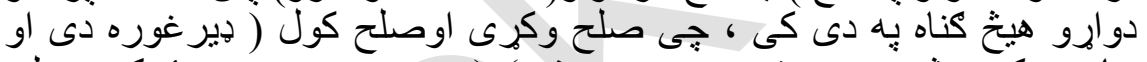

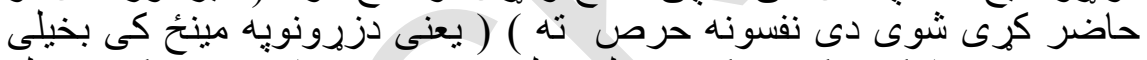

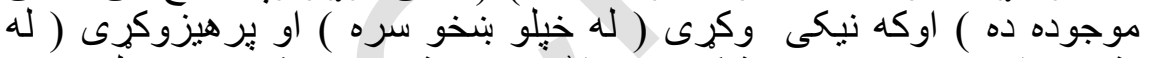

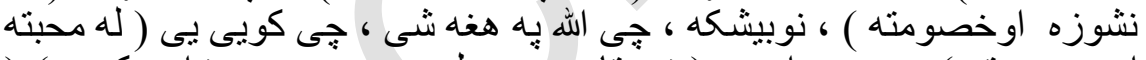

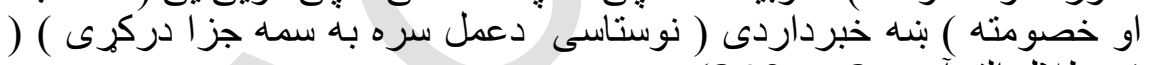

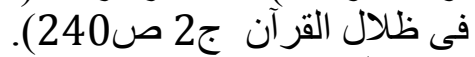

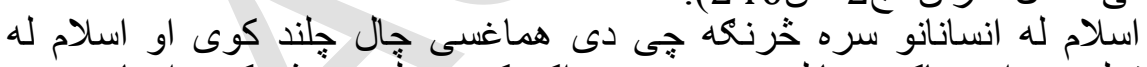

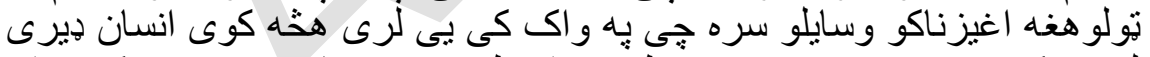

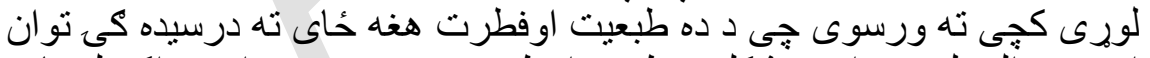

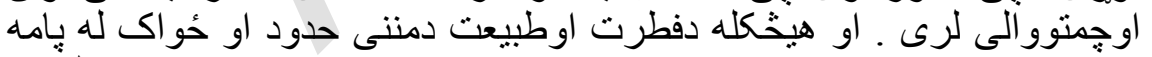

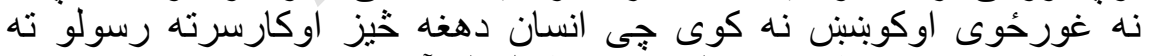

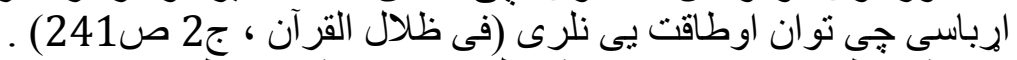

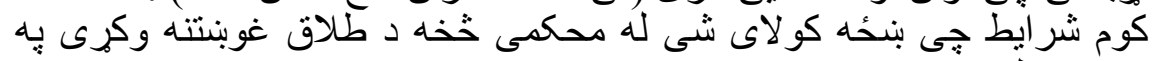

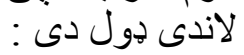

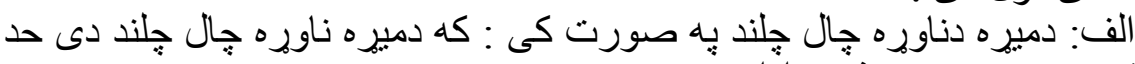

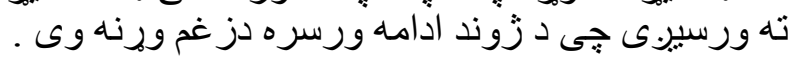




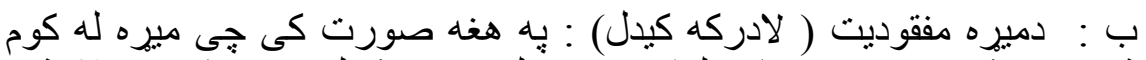

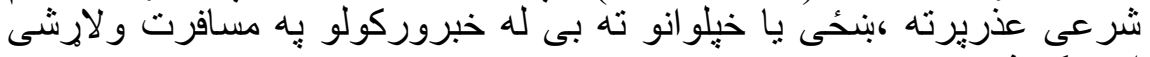

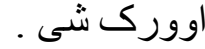

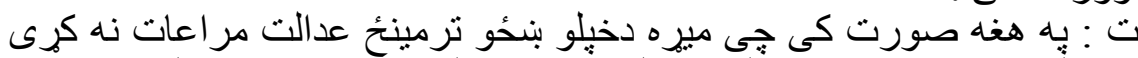

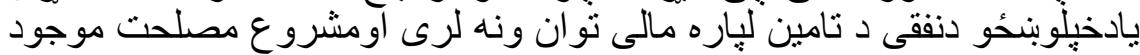

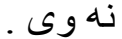

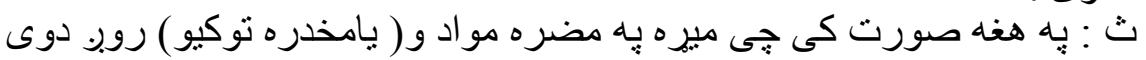

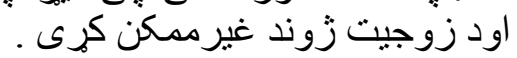
دطلاق ثبتول : درون

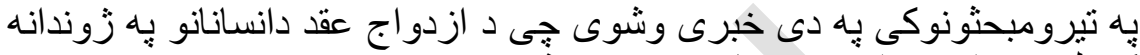

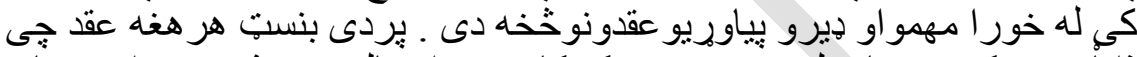

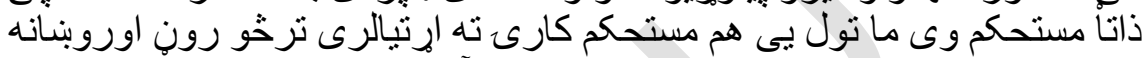

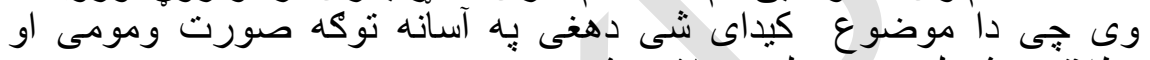

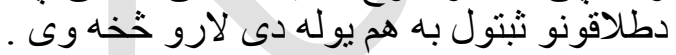

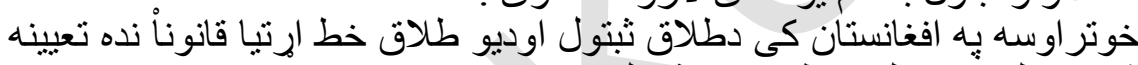

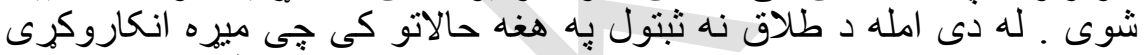

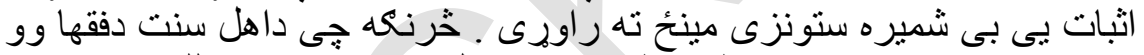

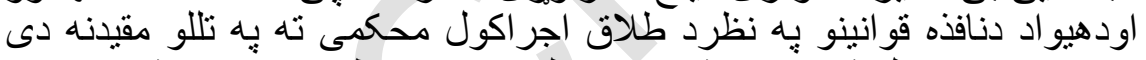

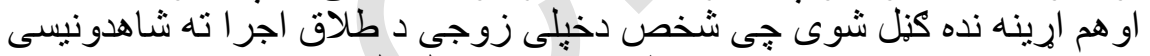

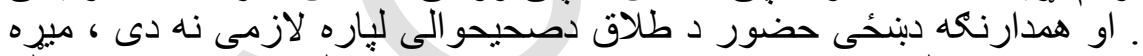

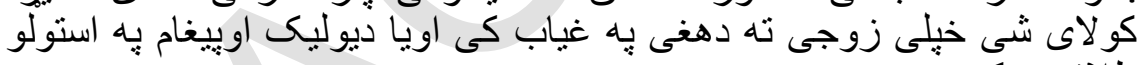
طلاق وركرى . كئ

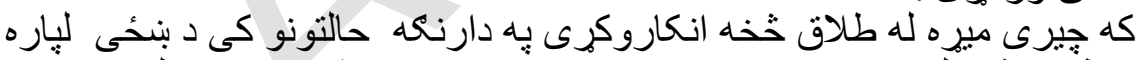

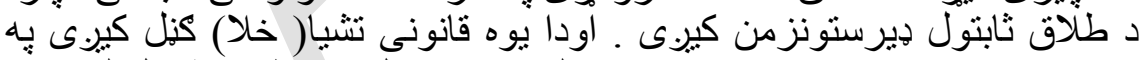

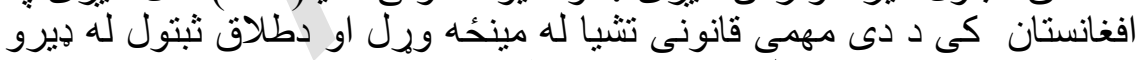

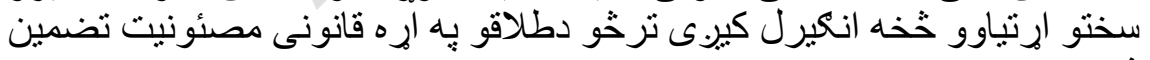




\section{كزارش اجرالت محاكم مركز وولايات كشور}

درمورد رسيده كى به قضاياى تجاوز جنسى و خشونت عليه زن فرن

\section{در سال 1395}

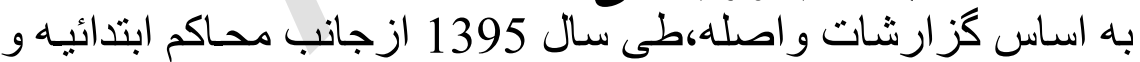

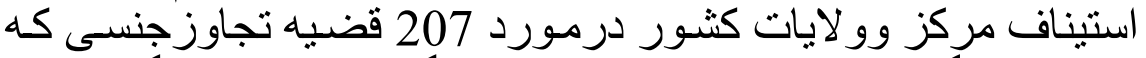

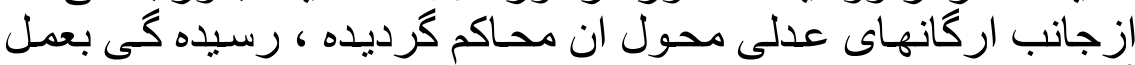

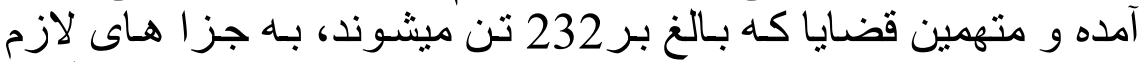

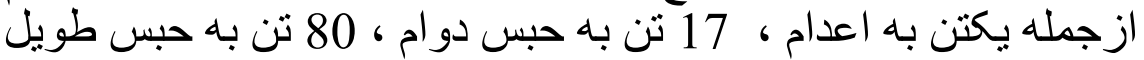

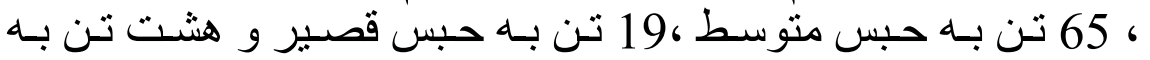


ازفعاليتهاى محاكم در رسيده كى به قضاياى تجاوز جنسى

قضضاء

جريمـه نقدى محكوم و 42 تن ازمتهمين بنابر عدم موجوديت دلايل

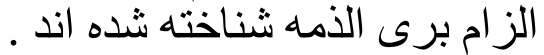

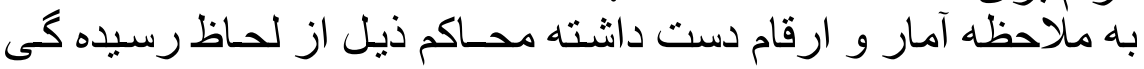
به قضاياى فوق در صدر قر ار دار دارند:

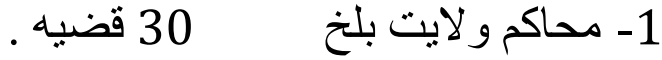

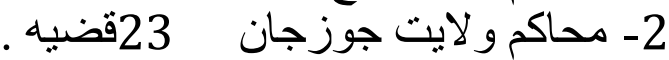

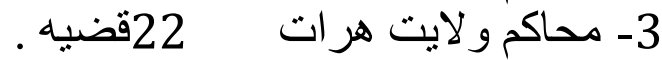
4- 3- محاكم و لايت كابل 19

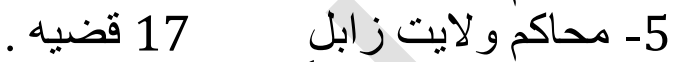

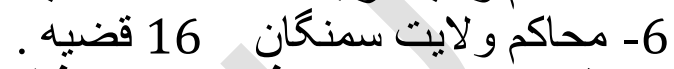

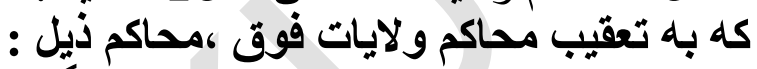

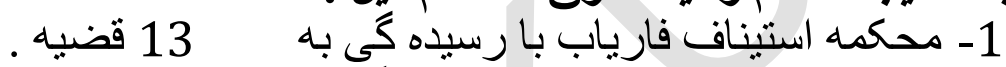

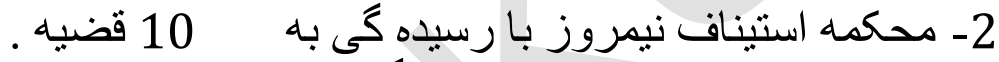

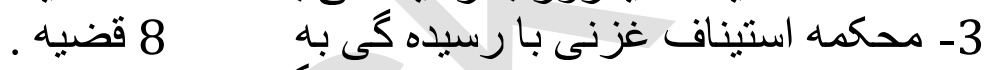

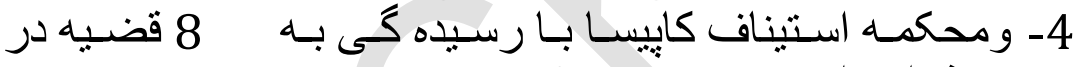

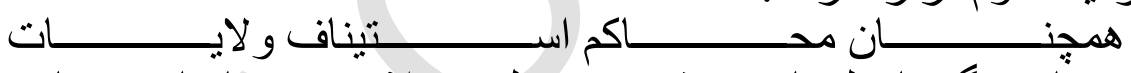

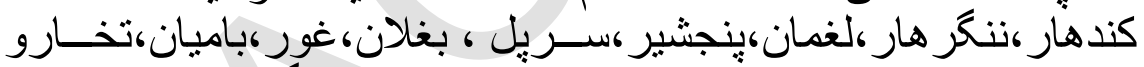

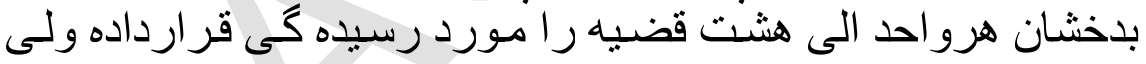

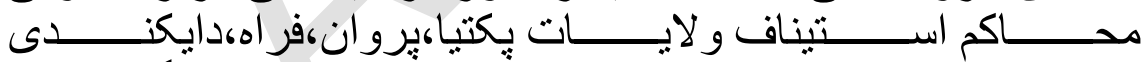

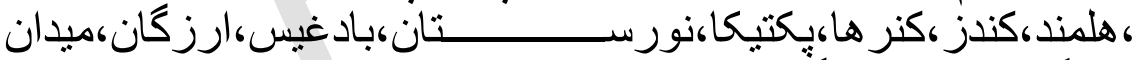

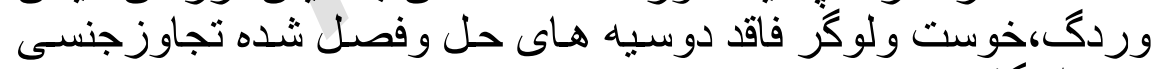
درسال كذشته بوده اند.

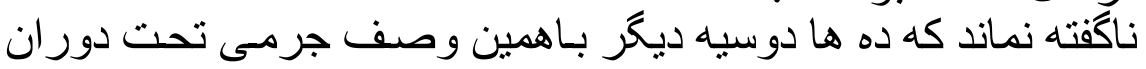

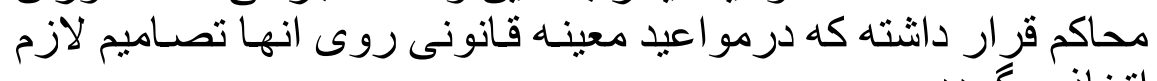
اتخاذ ميكردد .

ب : قضاياى خشونت عليه زن : 
ازفعاليتهاى محاكم در رسيده كَى به قضاياى تجاوز جنسى

قضاء

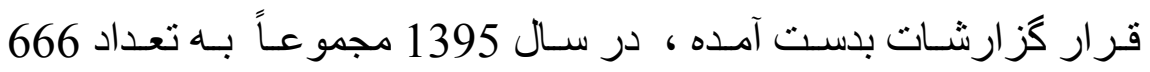

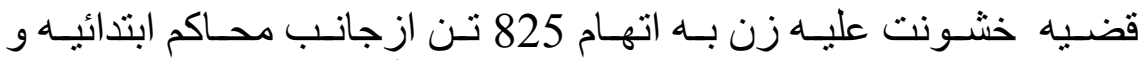

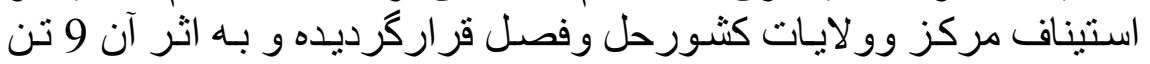

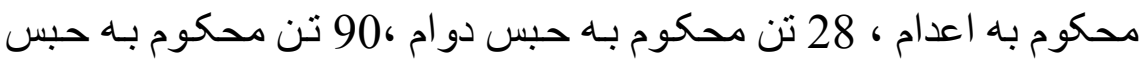

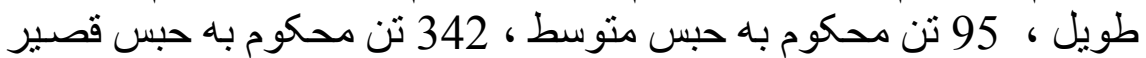

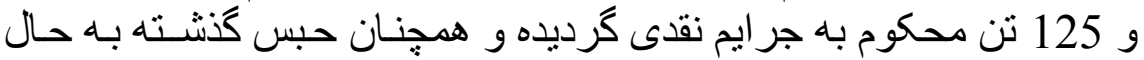

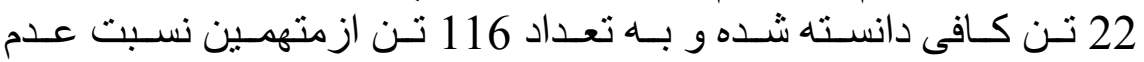

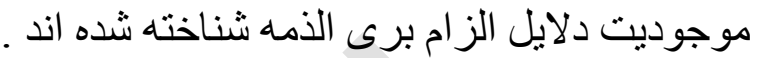

150 قضيه

122 قضيه

55 قضيه

52 قضيه

30

29

29 قضيه

27 قضيه

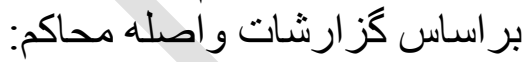

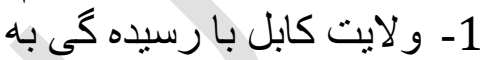

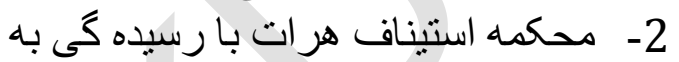

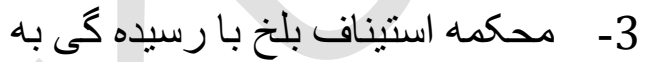

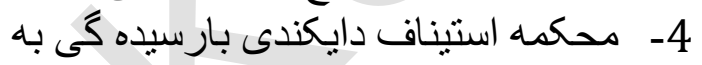

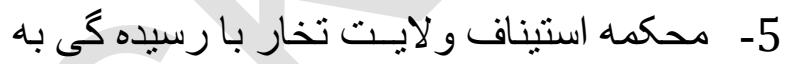

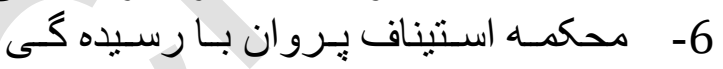
قضيه

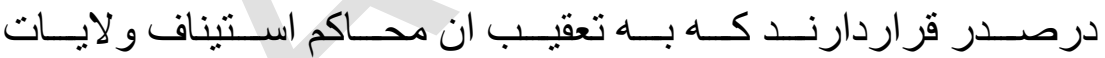

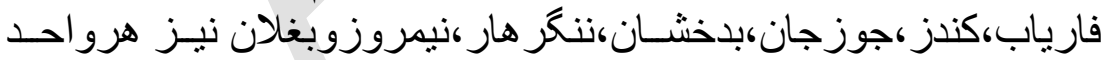

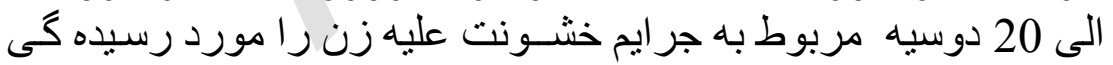

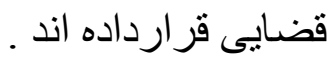

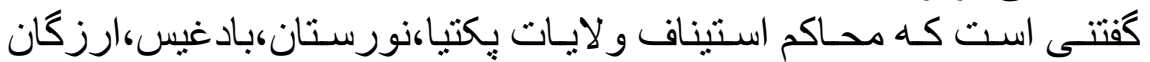

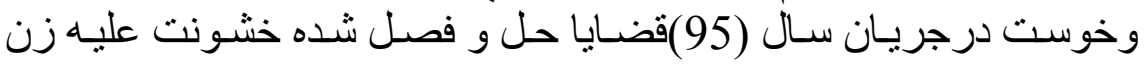

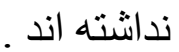
جداول مربوطه به قضـاياى رسيده كى شده تجاوز جنسى وخشونت عليه زن ذيلاً غرض ملاحظه تقديم است : نقائ 


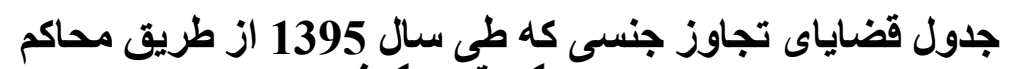

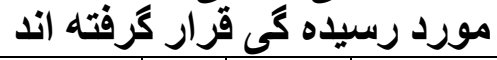

\begin{tabular}{|c|c|c|c|c|c|}
\hline تصميم قضائى & تاريخ جلسه قضائى & | ت متهدين & نوع قضيه & محكمه مربوطه & شماره \\
\hline بيست سال حبس تتفيذى & $1395 / 10 / 27$ & 1 & تجاوزجنسى & محكمه ابتدائيه خشونت عليه زن و لايت & 1 \\
\hline برى الذمه & $1395 / 10 / 13$ & 1 & رנ & נر & 2 \\
\hline נر & $1395 / 10 / 6$ & 1 & נر & رנ & 3 \\
\hline بيست سال حبس تتفيذى & $1395 / 10 / 13$ & 1 & נر & رנ & 4 \\
\hline رנ & $1395 / 8 / 24$ & 1 & رנر & رנ & 5 \\
\hline برى الذمه & $1395 / 8 / 3$ & 1 & رر & رנ & 6 \\
\hline هفت سال حبس تنفيذى & $1395 / 5 / 25$ & 1 & נر & رנر & 7 \\
\hline بيست سال حبس تنفيذى & $1395 / 12 / 29$ & 1 & رנ & رנ & 8 \\
\hline برى الذمه & $1395 / 12 / 16$ & 1 & رנ & رנ & 9 \\
\hline رر & נر & 1 & נر & נر & 10 \\
\hline ينج سال ويكماه حبس تنفيذى & $1395 / 3 / 8$ & 1 & رנ & |ديو ان رسيده كَى به جر ايجي خشونت عليه زن & 11 \\
\hline بر ائت & $1395 / 3 / 10$ & 1 & رנ & נر & 12 \\
\hline بر ائت & $1395 / 3 / 15$ & 1 & رנ & رנ & 13 \\
\hline نفر هفت هفت سال حبس تنفيذى نقدي & נر & $\Lambda$ & |تجاوزومجبو & 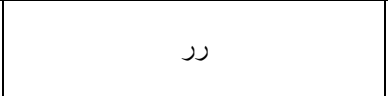 & 14 \\
\hline بر ائت & $1395 / 6 / 13$ & 1 & تجاوزجنسى & رر & 15 \\
\hline شانز ده شانزده سال حبس & $1395 / 7 / 5$ & 3 & رر & נر & 16 \\
\hline هفت سال حبس تنفيذى & $1395 / 7 / 27$ & 1 & رנ & رנ & 17 \\
\hline بيست سال حبس تنفيذى & $1395 / 12 / 2$ & 1 & ررواختطاف & رנ & 18 \\
\hline برى الذمه & $1395 / 12 / 16$ & 1 & ت تجاوزجنسى & נر & 19 \\
\hline سه سال حبس تتفيذى & $1395 / 2 / 20$ & 2 & تجاوزجنسى & ديو ان جز اى محكمه ابتدائيه شهرى هرات & 20 \\
\hline هفده سال حبس تتفيذى & $1395 / 3 / 4$ & 1 & رנ & رנ & 21 \\
\hline يكسال وششماه حبس تتفيذى & $1395 / 3 / 24$ & 1 & رנ & رנ & 22 \\
\hline ده سال حبس تتفيذى & $1395 / 4 / 9$ & 1 & رנ & رנ & 23 \\
\hline هزده سال حبس تتفيذى & $1395 / 4 / 31$ & 1 & נر & נر & 24 \\
\hline |هرو احد هشت سال حبس تتفيدى & $1395 / 5 / 11$ & 4 & رנ & رנ & 25 \\
\hline برى الذمه & $1395 / 5 / 17$ & 2 & נر & رנ & 26 \\
\hline بنج سال بكماه حبس & $1395 / 5 / 20$ & 1 & נر & נر & 27 \\
\hline بر ائت & $1395 / 6 / 7$ & 1 & נر & נر & 28 \\
\hline
\end{tabular}




\section{قاء}

\begin{tabular}{|c|c|c|c|c|c|}
\hline يكسال وشُشماه حبس تتفيذى & $1395 / 7 / 15$ & 1 & رנر & رנ & 29 \\
\hline اعدام & $1395 / 7 / 24$ & 1 & رנ & رر & 30 \\
\hline شش سال حبس تنفيذى & $1395 / 7 / 26$ & 1 & رر & رر & 31 \\
\hline ينج سال ويكماه حبس تنفيذى & $1395 / 9 / 20$ & 1 & رנ & رر & 32 \\
\hline دو ازده سال حبس تتفيذى & $1395 / 9 / 23$ & 1 & נر & رנر & 33 \\
\hline برى الذمه & $1395 / 7 / 12$ & 1 & رנر & ديو ان جز اى محكمه استيناف و لايت هر ات & 34 \\
\hline ل دو ازده ماه حبس تتفيذى & $1395 / 6 / 6$ & 1 & رנر & رנ & 35 \\
\hline ينج سال يكماه حبس تنفيذى & $1395 / 7 / 12$ & 1 & رנ & رנ & 36 \\
\hline | يُنج سال ويكماه حبس تنفيذى & $1395 / 2 / 28$ & 1 & رנر & ديو ان جز اى محكمه استيناف و لايت بلخ & 37 \\
\hline بنج سال حبس تنفيذى & $1395 / 3 / 5$ & 1 & رנ & رנ & 38 \\
\hline بنج سال حبس تتفيذى & $1395 / 3 / 16$ & 1 & رנر & 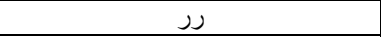 & 39 \\
\hline هشت سال حبس تتفيذى & $1395 / 3 / 29$ & 1 & رנر & 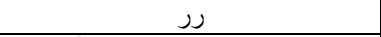 & 40 \\
\hline برى الذهـ & $1395 / 5 / 2$ & 1 & ادعاى تجاوز & رנر & 41 \\
\hline هرواحد بيست بيست سال حبس & $1395 / 5 / 26$ & 2 & تجاوزجنسى & g & 42 \\
\hline يكى بِّج سال ويكماه & $1395 / 6 / 27$ & 2 & נر & رנ & 43 \\
\hline | بِنج سال و يكماه حبس تنفيذى & $1395 / 8 / 1$ & 1 & رر & رر & 44 \\
\hline دوسال حبس تتفيذى & $1395 / 8 / 4$ & 1 & رנر & נر & 45 \\
\hline برى الذمه & $1395 / 9 / 16$ & 2 & رנر & رנ & 46 \\
\hline هشت سال حبس تتفيذى & $1395 / 9 / 30$ & 1 & رנ & رנر & 47 \\
\hline | هشت سال ويكماه حبس تتفيذى & رנ & 1 & 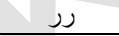 & رנ - (2- - مر & 48 \\
\hline شش سال حبس تنفيذى & $1395 / 10 / 8$ & 1 & رנ & 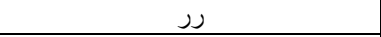 & 49 \\
\hline شش سال حبس تنفيذى & $1395 / 10 / 28$ & 1 & ر & رנ - مد - م & 50 \\
\hline 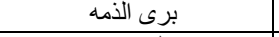 & $1395 / 11 / 2$ & 1 & رנ - (ر - م & 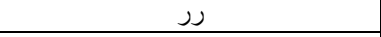 & 51 \\
\hline هفت سال حبس تتفيذى & $1395 / 11 / 4$ & 1 & נر & رנ & 52 \\
\hline هفت سال وششماه حبس تتفيذى & $1395 / 1 / 7$ & 1 & נر & ديوان رسيد گىى به تخلفات اطفال بلخ & 53 \\
\hline ل برى الذمه & $1395 / 3 / 25$ & 1 & נر & 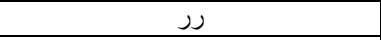 & 54 \\
\hline سه سال حجزتنفيذى & $1395 / 7 / 6$ & 1 & נر & رנ & 55 \\
\hline هشت سال حبس تتفيذى & $1395 / 1 / 31$ & 1 & رנر & ديو ان جزا محكمه ابتدائيه شهرى بلخ & 56 \\
\hline برى الذمه & $1395 / 4 / 12$ & 1 & נر & رנ & 57 \\
\hline برى الذمه & $1395 / 5 / 23$ & 1 & נر & رנ & 58 \\
\hline دوسال ويكماه حبس تتفيذى & $1395 / 7 / 6$ & 1 & נر & נر & 59 \\
\hline برى الذمه & $1395 / 8 / 10$ & 1 & تجاوزجنسى & 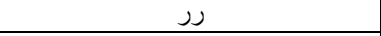 & 60 \\
\hline بيست سال حبس تتفيذى & $1395 / 8 / 3$ & 1 & נر & נر & 61 \\
\hline 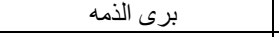 & $1395 / 9 / 1$ & 1 & تجاوزجنسى & 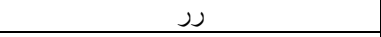 & 62 \\
\hline رر - ما & $1395 / 9 / 8$ & 1 & 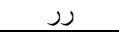 & 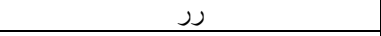 & 63 \\
\hline سه سال حجز تتفيذى & $1395 / 1 / 21$ & 1 & رد & رر - م - م & 64 \\
\hline دو سال و هفت ماه حجز تنفيذى & $1395 / 2 / 28$ & 1 & נر & رנ & 65 \\
\hline هشت سال حبس تنفيذى & $1395 / 5 / 4$ & 1 & נر & محكمه ابتدائيه ولسو الى مارمل بلخ & 66 \\
\hline شش سال حبس تتفيذى & $1395 / 2 / 25$ & 1 & رנ & ديو ان جزاى محكمه شهرى كندهار & 67 \\
\hline נر & $1395 / 11 / 9$ & 1 & رנ & נر & 68 \\
\hline بنج سال حبس تتفيذى & $1395 / 11 / 23$ & 1 & 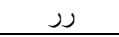 & 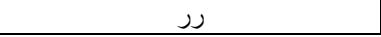 & 69 \\
\hline
\end{tabular}




\section{قاء}

\begin{tabular}{|c|c|c|c|c|c|}
\hline هرو احد ده سال حبس تتفيذى & $1395 / 6 / 13$ & 3 & رנ & رנ & 70 \\
\hline هفت سال حبس & $1395 / 9 / 10$ & 1 & ت تجاوزجنسى & ديو ان جز ا محكمه استيناف و لايت ننكر هار & 71 \\
\hline بر ائت & $1395 / 9 / 22$ & 1 & رנ & ر & 72 \\
\hline هفت سال حبس تتفيذى & $1394 / 12 / 11$ & 1 & رנ & حوزه اول محكمه استيناف و لايت ننكر هار & 73 \\
\hline بمدت يكسال حجز & $1395 / 1 / 8$ & 1 & 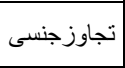 & 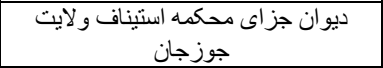 & 74 \\
\hline دوسال حبس تتفبذى & $1395 / 2 / 27$ & 1 & تجاوزجنسى & رנ & 75 \\
\hline شانزده حبس تتفيذى & $1395 / 5 / 3$ & 1 & تجاوزجنسى & رנ & 76 \\
\hline دوسال حبس تتفيذى & $1395 / 5 / 3$ & 1 & | تجاوزجنسى & ر & 77 \\
\hline ينج سال حبس تنفيذى & $1395 / 5 / 6$ & 1 & تجاوزجنسى & رנ & 78 \\
\hline يكسال حبس تنفيذى & $1395 / 5 / 18$ & 1 & تجاوزجنسى & رנ & 79 \\
\hline دو ازده سال حبس تنفيذى & $1395 / 5 / 24$ & 1 & تجاوزجنسى & رנ & 80 \\
\hline هشت سال حبس تنفيذى & $1395 / 7 / 11$ & 1 & تجاوزجنسى & קر & 81 \\
\hline ينج سال حبس تنفيذى & נر & 1 & تجاوزجنسى & ل & 82 \\
\hline ل رد & 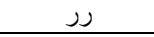 & 1 & تجاوزجنسى & 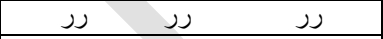 & 83 \\
\hline شش سال حبس تنفيذى & $1395 / 7 / 18$ & 2 & تجاوزجنسى & נر & 84 \\
\hline هشت سال حبس تنفيذى & $1395 / 8 / 2$ & 1 & تجاوزجنسى & رנ & 85 \\
\hline دوسال حبس تتفبذى & $1395 / 8 / 9$ & 1 & تجاوزجنسى & رנ رנ & 86 \\
\hline ده سال حبس تتفبذى & נر & 1 & تجاوزجنسى & رנ ر رנ & 87 \\
\hline يكسال حبس تنفيذى & رر & 1 & تجاوزجنسى & رנ & 88 \\
\hline ينج سال حبس تنفيذى & $1395 / 8 / 26$ & 1 & تجاوزجنسى & رנ & 89 \\
\hline ششماه حبس تنفيذى & $1395 / 9 / 28$ & 1 & تجاوزجنسى & رנ & 90 \\
\hline ينج سال حبس تنفيذى & $1395 / 10 / 1$ & 1 & |قدام به تجاوز & رנ & 91 \\
\hline يَنج سال حبس تنفيذى & $1395 / 10 / 5$ & 1 & تجاوزجنسى & נر & 92 \\
\hline رر & رر & 1 & تجاوزجنسى & رנ & 93 \\
\hline شانزده سال حبس تتفيذى & $1395 / 12 / 1$ & 1 & تجاوزجنسى & נر & 94 \\
\hline ينج ينج سال حبس تتفيذى & دونفر & 2 & تجاوزجنسى & رد & 95 \\
\hline شش شش سال حبس تنفبذى & $1395 / 10 / 1$ & 2 & تجاوزجنسى & رر & 96 \\
\hline ينج سال ويكماه حبس تتفيذى & $1395 / 4 / 21$ & 1 & تجاوزجنسى & ديو ان جزاى محكمه استيناف و لايت لغمان & 97 \\
\hline يكسال حبس تتفيذى & $1395 / 10 / 26$ & 1 & | تجاوزجنسى & رנ & 98 \\
\hline يكنفر سه سال وجهار ماه حجزو & $1395 / 10 / 7$ & 2 & נر & ديوان جز اى استيناف ولايت بِنشير & 99 \\
\hline دوماه ودوروز حبس تتفيذى & $1395 / 9 / 22$ & 2 & تجاوزجنسى & محكمه خنجان بِنجشبر & 100 \\
\hline يكنفرسه سال وجهارماه & $1395 / 8 / 10$ & 2 & لو اط & ديو ان جز اى محكمه شهرى بيجشير & 101 \\
\hline بر ائت & $1395 / 3 / 31$ & 2 & خود كشى & נر & 102 \\
\hline سه سال وششماه حجز & $1395 / 7 / 30$ & 1 & ت تجاوزجنسى & ديو ان جز اى محكمه استيناف و لايت سريّل & 103 \\
\hline سه سال و شُماه حجز & $1395 / 6 / 9$ & 1 & | تجاوزجنسى & ديو ان جز اى محكمه شهرى سربِل & 104 \\
\hline بر ائت & $1395 / 10 / 20$ & 1 & | تجاوزجنسى & رנ & 105 \\
\hline هرواحد ينج ينج سال حبس & $1395 / 10 / 25$ & 1 & | تجاوزجنسى & محكمه ابتدائيه ولسو الى بلخ آب سربل & 106 \\
\hline ششماه حبس تنفيذى & $1395 / 5 / 7$ & 1 & ت تجاوزجنسى & ديوان جزاى استيناف و لايت نبمروز & 107 \\
\hline ليكنفرجهارسال دومى شش سال & $1395 / 5 / 30$ & 2 & رנ ر رנ & رر & 108 \\
\hline
\end{tabular}




\section{قاء}

\begin{tabular}{|c|c|c|c|c|c|}
\hline جهارماه حبس تتفيذى & $1395 / 1 / 5$ & 1 & קر & ديو ان محكمه ابتدائيه ولايت نيمروز & 109 \\
\hline يكسال حجز & $1395 / 1 / 30$ & 1 & - م & 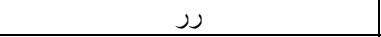 & 110 \\
\hline حفظ دوسيه زيرسن قانونى & رנ - (ر - م & 1 & - ا & 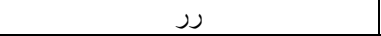 & 111 \\
\hline دوماه حبس تنفيذى & $1395 / 1 / 29$ & 1 & 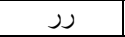 & رנ & 112 \\
\hline سه سال حجز & $1395 / 3 / 30$ & 1 & | & رנ & 113 \\
\hline ينج سال حبس تنفيذى & $1395 / 8 / 7$ & 1 & ا & رر & 114 \\
\hline برائت & $1395 / 7 / 1$ & 1 & رנ رر & رر & 115 \\
\hline ششماه حبس تنفيذى & $1395 / 10 / 19$ & 1 & لي & رנ & 116 \\
\hline ينج سال وده روزحبس تتفيذى & $1395 / 11 / 14$ & 1 & تجاوزجنسى & ديو ان جز اى محكمه استيناف و لايت بغلان & 117 \\
\hline برى الذمه & $1395 / 11 / 20$ & 1 & رנ & رנر & 118 \\
\hline برى الذهـ & $1395 / 12 / 5$ & 1 & | اقدام به تجاوز & رנ & 119 \\
\hline دو ازده سال حبس تتفيذى & $1395 / 12 / 8$ & 1 & ت تجاوزجنسى & נر & 120 \\
\hline تعين مهرمثل & $1395 / 2 / 27$ & 1 & رנ & ديوان جزاى محكمه شهرى و لايت سمنگان & 121 \\
\hline جهار سال حجز & $1395 / 2 / 26$ & 1 & ر & رנ & 122 \\
\hline برى الذهه & $1395 / 3 / 23$ & 1 & 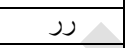 & ر & 123 \\
\hline هفت سال حجز & $1395 / 3 / 27$ & 1 & 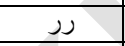 & رנ & 124 \\
\hline دوسال حبس تتفيذى & $1395 / 9 / 23$ & 1 & ر & נر & 125 \\
\hline سه سال وششماه حبس تتفيذى & $1395 / 10 / 7$ & 1 & נر & 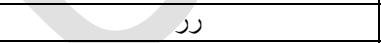 & 126 \\
\hline يكى سال وششماه حبس تتفيذى & 1395/11/19 & 1 & رנ & رנ - (2- مر & 127 \\
\hline هفت سال وششماه حجز & $1395 / 3 / 30$ & 1 & رנ & ديوان جزاى محكمة استيناف ولايت & 128 \\
\hline جهارسال حجز & $1395 / 4 / 30$ & 1 & נر & رנ & 129 \\
\hline برائت & $1395 / 5 / 30$ & 1 & ر & رנ & 130 \\
\hline يكى بنج سال ود ومى سه سال & $1395 / 6 / 17$ & 2 & 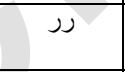 & נر & 131 \\
\hline دو سال وششماه حبس تنفيذى & $1395 / 7 / 28$ & 1 & رנ - لا & رנ & 132 \\
\hline يدوسال حبس تتفيذى & $1395 / 11 / 20$ & 1 & رر & رر & 133 \\
\hline دو دوسال حبس تتفيذى & رر & 2 & رנ & رנ & 134 \\
\hline هرو احد دو سال وششماه حجز & $1395 / 7 / 18$ & 2 & رנ & رנ & 135 \\
\hline لدو سال وششماه حجز & $1395 / 8 / 12$ & 1 & رנ & رנ & 136 \\
\hline برائت & $1395 / 5 / 2$ & 2 & ر & ديوان جز اي محكمه استيناف غور & 137 \\
\hline ينج سال حبس تنفيذى & $1395 / 11 / 5$ & 1 & |قدام بتجاوز & ديوان جزاى استيناف و لايت زابل & 138 \\
\hline وديكردو يكنفرشه سال حبس حبن تنفيذى & $1395 / 9 / 30$ & 2 & |تجاوزجنسى & נر & 139 \\
\hline هرو احد سه سال حبس تنفيذى & $1395 / 7 / 13$ & 2 & |قدام بتجاوز & رנ & 140 \\
\hline جهارسال حبس تتفيذى & $1395 / 10 / 7$ & 1 & تجاوزجنسى & ديو ان جزاى شهرى و لايت زابل & 141 \\
\hline هرواحد جهارسال حبست & $1395 / 7 / 13$ & 2 & נر & رد & 142 \\
\hline برائت & $1395 / 1 / 17$ & 1 & ر & ديو ان جزاى محكمه استيناف و لايت زابل & 143 \\
\hline ينج سال حبس تنفيذى & $1395 / 1 / 28$ & 1 & ر & 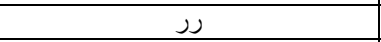 & 144 \\
\hline بنج سال ويكماه حبس تنفيذى & 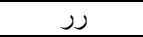 & 1 & رנر & رנر & 145 \\
\hline شش سال حبس تنفيذى & $1395 / 4 / 5$ & 1 & رנر & رנ & 146 \\
\hline هرو احد يكسال حبس تنفيذى & $1395 / 5 / 19$ & 2 & رנ & رנر & 147 \\
\hline
\end{tabular}




\section{قاء}

\begin{tabular}{|c|c|c|c|c|c|}
\hline يكسال ونه ماه حبس تتفيذى & $1395 / 7 / 27$ & 2 & رر & ر & 148 \\
\hline دوسال وشُشماه حبس تنفيذى & $1395 / 9 / 1$ & 1 & رנ & رנ & 149 \\
\hline برائت & $1395 / 9 / 30$ & 1 & ر & رر & 150 \\
\hline هرواحد بِنزيذد سال حبس & $1395 / 10 / 13$ & 3 & נر & נر & 151 \\
\hline شش سال حبس تنفيذى & $1395 / 11 / 14$ & 1 & رر & رנ & 152 \\
\hline بذجج سال ويكماه حبس تتفيذى & $1395 / 11 / 19$ & 1 & رנ & رנ & 153 \\
\hline شانزده سال حبس تنفيذى & $1395 / 12 / 19$ & 1 & ر & ر & 154 \\
\hline بر ائت & $1395 / 5 / 21$ & 1 & ر & محكمه ابتدائيه يكه ولنگ و لايت باميان & 155 \\
\hline ينج سال حبس تنفيذى & $1395 / 6 / 16$ & 1 & رנ & נر & 156 \\
\hline بيست سال حبس تنفيذى & $1395 / 1 / 22$ & 1 & ر & ديو ان جز اى محكمه استيناف تخار & 157 \\
\hline هرو احد شانزده شانز ده سال & $1395 / 4 / 2$ & 2 & رנ & נر & 158 \\
\hline شش سال حبس تنفيذى & $1395 / 7 / 11$ & 1 & رر & رנ & 159 \\
\hline ينج سال وششماه حبس تتفيذى & $1395 / 7 / 13$ & 1 & رر & رנر & 160 \\
\hline هرو احد شانزده شانز ده سال & $1395 / 8 / 30$ & 2 & נر & رر & 161 \\
\hline إينج سال و هفت ماه حبس تتفيذى & $1395 / 8 / 27$ & 1 & ر & ر & 162 \\
\hline سه ماه حجز تتفيذى & $1395 / 10 / 8$ & 1 & ر & ر & 163 \\
\hline سه ماه حبس تنفيذى & $1395 / 11 / 12$ & 1 & ر & رנ & 164 \\
\hline ينج سال ويكماه حبس تنفيذى & $1395 / 12 / 1$ & 1 & ر & ر & 165 \\
\hline دو سال حبس تتفيذى & $1394 / 3 / 17$ & 1 & נر נر & ديوان جزاى محكمه استيناف و لايت تخار & 166 \\
\hline شانزده سال حبس & $1394 / 4 / 7$ & 1 & آ & رנ & 167 \\
\hline بيست سال حبس & $1394 / 4 / 14$ & 1 & رנر رנ & נر נر & 168 \\
\hline سه سال حبس & $1394 / 5 / 7$ & 1 & رנ رנ & رנ رנ & 169 \\
\hline بر ائت & $1394 / 9 / 18$ & 1 & נر رנ & رנ رנ & 170 \\
\hline بر ائت & $1394 / 11 / 21$ & 1 & رנ رנ & נر נر & 171 \\
\hline بيست سال حبس & $1394 / 2 / 13$ & 1 & رנ رנ & נر נر & 172 \\
\hline شانز ده سال حبس & $1394 / 2 / 13$ & 1 & נر رנ & رנ رנ & 173 \\
\hline شانزده سال حبس & $1394 / 2 / 27$ & 1 & رנ رנ & رנ رנ & 174 \\
\hline جهارسال حبس & $1394 / 5 / 4$ & 1 & נر נر & נر נر & 175 \\
\hline هزده سال حبس & $1394 / 6 / 15$ & 1 & נر נر & נر נر & 176 \\
\hline جهار هزارجريمه نقدى & $1394 / 8 / 13$ & 1 & رנ رر & رנ رر & 177 \\
\hline يُنج سال حبس تنفيذى & $1395 / 1 / 29$ & 1 & رנ & ديو ان جز اى محكمه استيناف و لايت فارياب & 178 \\
\hline ده سال حبس تتفيذى & $1395 / 2 / 26$ & 1 & ر & ر & 179 \\
\hline هرو احد شانزده سال حبس & $1395 / 5 / 16$ & 2 & נر & נر & 180 \\
\hline يُنج سال حبس تنفيذى & $1395 / 5 / 19$ & 1 & رנ & رנ & 181 \\
\hline بر ائت & $1395 / 6 / 14$ & 3 & ر & ر & 182 \\
\hline يُجج سال وششماه حبس تتفيذى & $1395 / 8 / 9$ & 1 & ر & رנ & 183 \\
\hline هرو احد شانزده سال حبس & $1395 / 9 / 30$ & 2 & נر & נر & 184 \\
\hline بر ائت & $1395 / 10 / 14$ & 2 & رر & رر & 185 \\
\hline شش سال حبس تنفيذى & $1395 / 10 / 10$ & 1 & 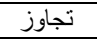 & ديوان جز اى محكمه استيناف غزنى & 186 \\
\hline
\end{tabular}

\section{1}




\section{قائ}

\begin{tabular}{|c|c|c|c|c|c|}
\hline بيست سال حبس تنفيذى & $1395 / 10 / 27$ & 1 & رנ & رנ & 187 \\
\hline هرو احد بِنج سال ودوماه حبس & $1394 / 7 / 21$ & 2 & رر رر & رر & 188 \\
\hline شانزده سال حبس تتفيذى & $1394 / 7 / 21$ & 1 & ( & נر נر & 189 \\
\hline بيست سال حبس تنفيذى & $1394 / 8 / 12$ & 1 & ر & رנ & 190 \\
\hline شانزده سال حبس تتفيذى & $1394 / 9 / 3$ & 1 & رנ رנ & נر & 191 \\
\hline نه سال وسه ماه حبس تتفيذى & $1394 / 10 / 15$ & 1 & رد رנ & נر & 192 \\
\hline يكسال حبس تنفيذى & $1394 / 6 / 3$ & 1 & | تجاوزجنسى & ديو ان جز اى محكمه استيناف و لايت غزنى & 193 \\
\hline نه ماه حجز & $1394 / 1 / 23$ & 1 & 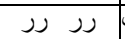 & ديو ان جزاى محكمه استيناف و لايت فارياب & 194 \\
\hline يكسال حبس تنفيذى & $1394 / 3 / 19$ & 1 & آ آ آ رر & رנ رנ & 195 \\
\hline جهارسال حبس تنفيذى & $1394 / 9 / 15$ & 1 & - آ & رנ & 196 \\
\hline ينج سال حبس تنفيذى & $1394 / 6 / 7$ & 1 & رر رر & رر & 197 \\
\hline شانز ده سال حبس & $1394 / 5 / 18$ & 1 & - آ & رر رנ & 198 \\
\hline نه سال حبس تنفيذى & $1395 / 4 / 23$ & 1 & ر & ديو ان جزاى محكمه شهرى بدخشان & 199 \\
\hline بر ائت & $1395 / 4 / 12$ & 1 & رر & ديوان جز اى محكمه استيناف و لايت كاييسا & 200 \\
\hline شانز ده سال حبست تتفبذى & $1395 / 5 / 25$ & 1 & נر & رנ & 201 \\
\hline بر ائت & $1395 / 12 / 11$ & 1 & נر & ر & 202 \\
\hline سه ماه حجز تنفيذى & $1395 / 11 / 27$ & 1 & ر & ر & 203 \\
\hline هزّده سال حبس تنفيذى & $1395 / 4 / 9$ & 1 & נر & محكمه شهرى ولايت كايِيسا & 204 \\
\hline يكسال وششماه حبس تتفيذى & $1395 / 9 / 3$ & 1 & נر & رנ & 205 \\
\hline شانزده سال حبس تتفيذى & $1395 / 11 / 13$ & 1 & رנ & נر & 206 \\
\hline \multirow[t]{2}{*}{ شانز ده سال وششماه حبست } & $1395 / 11 / 27$ & 1 & נر & נر & 207 \\
\hline & & 232 & & & 208 \\
\hline
\end{tabular}

\section{جدول قضاياى خشونت عليه زن كه طى سال 1395 از طريق محاكم

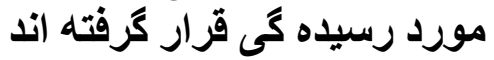




\section{قـضئ}

\begin{tabular}{|c|c|c|c|c|c|}
\hline تصميم قضايى & |تاريخ جلسه قضايى| & $\begin{array}{l}\frac{\xi}{k} \\
\frac{L}{E}\end{array}$ & نوع اتهام & محكمه مريوطه & شماره \\
\hline ششماه حبس تنفيذى & $1395 / 2 / 26$ & 1 & ازمكارووظيفه & 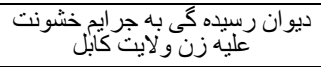 & 1 \\
\hline بازده سال حبس تتفيذى & $1395 / 3 / 1$ & 1 & ضرب منجربه مرك | & 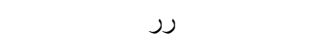 & 2 \\
\hline جريمه نقدى & $1395 / 3 / 24$ & 1 & لت وكوب & 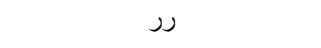 & 3 \\
\hline شانز ده سال حبس تتفيذى & $1395 / 5 / 4$ & 1 & | خشونت منجربه قتل | & رد & 4 \\
\hline هشت سال حبس تتفيذى & $1395 / 5 / 9$ & 1 & | خود سوزي منجربها & 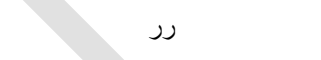 & 5 \\
\hline يكسال وششئماه حبس & $1395 / 5 / 18$ & 1 & ل لت وكوب & נر & 6 \\
\hline هفت سال حبس تتفيذى & $1395 / 5 / 23$ & 1 & مسبب خود كثىى & 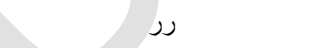 & 7 \\
\hline دوسال حبس تتفيذى & $1395 / 5 / 30$ & 1 & نكاح اجبارى & 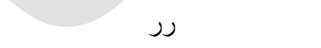 & 8 \\
\hline بنجج سال ويكيكماه حبس & נر & 1 & مسبب خود كثى & $\gamma$ & 9 \\
\hline بنج سال ودو ماه حبس & $1395 / 6 / 6$ & 1 & رנ & رנ & 10 \\
\hline 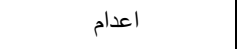 & $1395 / 6 / 13$ & 1 & قتل & 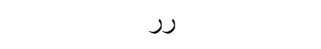 & 11 \\
\hline سه ماه حبس تتفيذى & $1395 / 6 / 15$ & 1 & آزارو اذيت & رد - ت ار & 12 \\
\hline شانزده سال حبس تتفيذى & $1395 / 6 / 20$ & 1 & قتل & 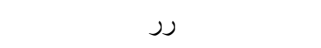 & 13 \\
\hline برى الذمه & $1395 / 7 / 3$ & 1 & ل لت وكوب & נر & 14 \\
\hline شانزده سال حبس تتفيذى & رנ & 1 & | خشونت منجربه قتل | & נر & 15 \\
\hline برى الذمه & $1395 / 7 / 6$ & 1 & ل لت وكوب & رد - ت إ & 16 \\
\hline شانزده سال حبس تتفيذى & 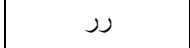 & 1 & قتل & 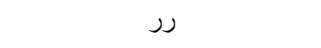 & 17 \\
\hline جهارماه حبس تتفيذى & $1395 / 7 / 19$ & 1 & لت وكوبى & رد - ت ار & 18 \\
\hline بنج ودومى ويكمائ حبس & $1395 / 7 / 24$ & 2 & خود سوزي منجربه & رנ & 19 \\
\hline برى الذمه & $1395 / 8 / 8$ & 1 & |زدواج زيش ازيك |ز & رנ & 20 \\
\hline بنج سال ويكماه حبس & رנ & 1 & مسبب خود كثى & נر & 21 \\
\hline
\end{tabular}

\section{3}




\section{قـضئ}

\begin{tabular}{|c|c|c|c|c|c|}
\hline شانزده سال حبس تتفيذى & $1395 / 9 / 20$ & 1 & قتل & 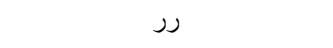 & 22 \\
\hline سه سال وتفيذه ماه حبس & $1395 / 10 / 4$ & 1 & مسبب خود كثىى & 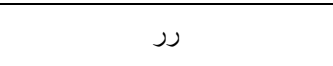 & 23 \\
\hline برى الذهـ & $1395 / 10 / 18$ & 3 & مسبب بقتل & رد - ت ار & 24 \\
\hline رנ & $1395 / 10 / 20$ & 1 & قتل & 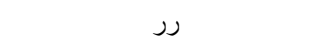 & 25 \\
\hline يكسال وششيذماه حبس & $1395 / 10 / 25$ & 1 & لو اطولت وكوب & 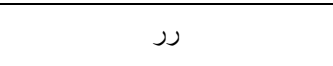 & 26 \\
\hline برى الذهـ & رد - ت ار & 2 & مسبب خود كثى & 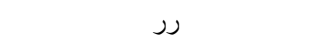 & 27 \\
\hline هفده سال حبس تتفيذى & $1395 / 11 / 9$ & 1 & قتل & 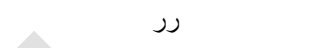 & 28 \\
\hline جهارماه حبس تنفيذى & 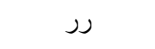 & 1 & ل لت وكوب & 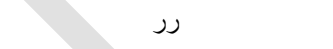 & 29 \\
\hline يكسال حبس تنفيذى & $1395 / 11 / 24$ & 1 & 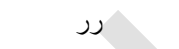 & رد - ت ار & 30 \\
\hline ششماه حبس تنفيذى & $1395 / 11 / 25$ & 1 & رر & رد - ت ار & 31 \\
\hline 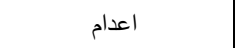 & $1395 / 12 / 7$ & 1 & قتل & ر & 32 \\
\hline هرو احد ينازذه سال حبس & $1395 / 1 / 32$ & 2 & خو نكثى & ديوان جز اى محكمات ابتدائيه شهرى & 33 \\
\hline | هانزده روزحبس تنفيذى & $1395 / 1 / 28$ & 1 & رנ & נر - ت ا & 34 \\
\hline يك ماه حبس تنفيذى & $1395 / 2 / 13$ & 1 & لت وكوب & رر & 35 \\
\hline بيست سال بس تتفيذى & $95 / 2 / 23$ & 1 & ضرب منجربقتل & 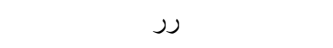 & 36 \\
\hline سه ماه حبس تنفيذى & $1395 / 3 / 3$ & 1 & لت وكوب & رد & 37 \\
\hline נر & ر & 1 & رנ & 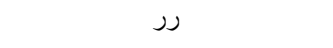 & 38 \\
\hline بيست سال حبس تتفيذى & $1395 / 3 / 11$ & 1 & خشونت منجربقتل & 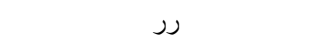 & 39 \\
\hline بنج ماه حبس & $1395 / 3 / 22$ & 1 & لت وكوب & رد & 40 \\
\hline جهارماه حبس تتفيذى & رנ & 1 & נر & 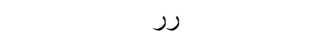 & 41 \\
\hline ششماه حبس تنفيذى & $95 / 4 / 6$ & 1 & لت وكوب & رد & 42 \\
\hline נر & $1395 / 4 / 9$ & 1 & נر & נر & 43 \\
\hline سه ماه حبس تنفيذى & رנ & 1 & رנ & رנ & 44 \\
\hline سه ماه حبس تتفيذى & $1395 / 5 / 7$ & 1 & آزارو اذيت & 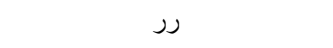 & 45 \\
\hline
\end{tabular}

\section{4}




\section{قـضئ}

\begin{tabular}{|c|c|c|c|c|c|}
\hline ده سال حبس تنفيذى & $1395 / 5 / 14$ & 1 & مجروحيت منجربه & נر - ت ار & 46 \\
\hline دوماه حبس تتفيذى & $1395 / 5 / 16$ & 1 & لت وكوبى & رر & 47 \\
\hline ششماه حبس تتفيذى & $1395 / 5 / 20$ & 1 & 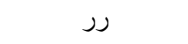 & 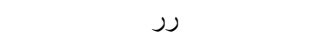 & 48 \\
\hline يكسال ششماه حبس ويك & $1395 / 5 / 20$ & 2 & خود كثى & رנ & 49 \\
\hline هرو احد ينج سال حبس & $1395 / 5 / 24$ & 3 & נر & 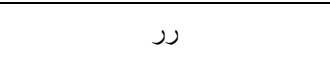 & 50 \\
\hline ششماه حبس تنفيذى & נر & 1 & ل تلت وكوب & رנ & 51 \\
\hline رد - ت ار & $1395 / 6 / 4$ & 1 & خو دكثى & 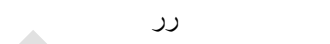 & 52 \\
\hline ششماه حبس تتفيذى & $1395 / 6 / 15$ & 1 & لت وكوب & رد - لَ & 53 \\
\hline يكماه حبس تتفيذى & $1395 / 7 / 4$ & 1 & تهديد & 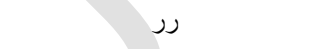 & 54 \\
\hline ششماه حبس تنفيذى & $1395 / 7 / 8$ & 1 & رנ & رد - ت ار & 55 \\
\hline سه ماه حبس تنفيذى & $1395 / 7 / 10$ & 1 & 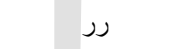 & 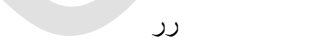 & 56 \\
\hline يكسال وشيذى تشاه حبس & $1395 / 7 / 18$ & 1 & لت وكوب & رנ & 57 \\
\hline يكسال وششيذى & $1395 / 7 / 20$ & 2 & ت تهديد & رנ & 58 \\
\hline بر ائت & $1395 / 7 / 22$ & 2 & آزار و اذيت & נر & 59 \\
\hline ششماه حبس تتفيذى & $1395 / 3 / 6$ & 1 & مجروحيت & ديو ان جز اى محكرمار استيناف و لايت & 60 \\
\hline جريمه نقدى & $1395 / 5 / 11$ & 1 & لت وكوبى & 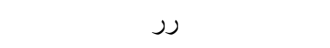 & 61 \\
\hline شانزده سال حبس تتفيذى & $1395 / 6 / 17$ & 1 & 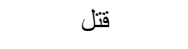 & 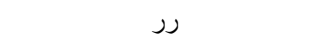 & 62 \\
\hline هرواحد بيست بيست حبس & $1395 / 10 / 4$ & 3 & 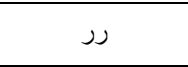 & 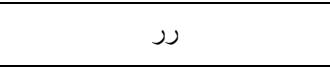 & 63 \\
\hline |هرواحد دو - دوسال حبس تبسى & رנ & 2 & 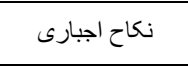 & 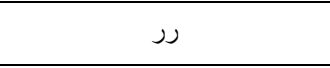 & 64 \\
\hline دوسال حبس تتفيذى & $1395 / 11 / 11$ & 1 & آزار و اذيت & 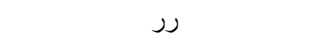 & 65 \\
\hline سه ماه حبس تتفيذى & 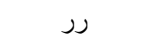 & 1 & خشونت & 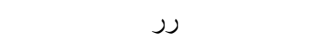 & 66 \\
\hline دو ازده سال حبس تتفيذى & $1395 / 8 / 10$ & 1 & 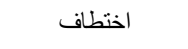 & 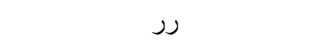 & 67 \\
\hline هفت ماه حبس تتفيذى & $1395 / 1 / 4$ & 1 & مجروحيت & 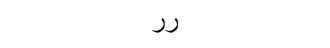 & 68 \\
\hline سه سال حبس تنفيذى & $1395 / 5 / 9$ & 1 & تحريك به فسق & 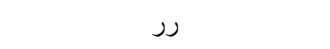 & 69 \\
\hline
\end{tabular}

\section{5}




\section{قـضاء}

\begin{tabular}{|c|c|c|c|c|c|c|c|}
\hline دوماه حبس & $1395 / 1 / 8$ & 1 & خشونت & \multicolumn{3}{|c|}{ ديو ان جزاى استيناف و لايت جوزجان } & 70 \\
\hline سه ماه حبس & $1395 / 1 / 25$ & 1 & 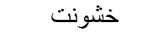 & رد & رנ & נر & 71 \\
\hline ينج سال حبس & $1395 / 2 / 26$ & 1 & رנ & נر & رر & נر & 72 \\
\hline بكسال حبس & $1395 / 2 / 27$ & 1 & נر & נر & נر & 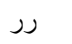 & 73 \\
\hline يكسال حبس & $1395 / 2 / 27$ & 1 & נر & נر & 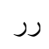 & נر & 74 \\
\hline سه ماه حبس & $1395 / 3 / 23$ & 1 & נر & נر & رر & נر & 75 \\
\hline دوسال حبس & $1395 / 5 / 6$ & 1 & 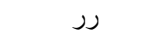 & 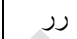 & رد & נر & 76 \\
\hline ينج ينج سال حبس & $1395 / 5 / 18$ & 2 & 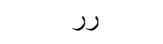 & رנ & رر & رد & 77 \\
\hline يُج ينج سال حبس & $1395 / 7 / 11$ & 2 & رנ & נر & رر & 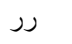 & 78 \\
\hline ينج سال ودو ماه حبس & $1395 / 8 / 2$ & 1 & 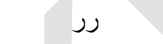 & נر - ت ار & رנر & נر & 79 \\
\hline ش ش ماه حبس & $1395 / 8 / 16$ & 1 & נر & رر & رر & رנ & 80 \\
\hline شانزده سال حبس & $1395 / 5 / 17$ & 1 & 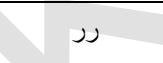 & ل بلايت & 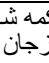 & ديوان & 81 \\
\hline شش ماه حبس & $1395 / 2 / 31$ & 1 & 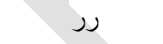 & 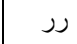 & 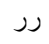 & נر & 82 \\
\hline سه ماه حبس & $1395 / 7 / 4$ & 1 & رנر & رנ & رנ & נر & 83 \\
\hline بر ائت الذمه & $1395 / 7 / 13$ & 1 & خشونت & 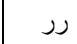 & נر & נر - ت اנ & 84 \\
\hline بيست بوم حبس & $1395 / 8 / 11$ & 1 & رנ & נر - ت ا & رנ & נر & 85 \\
\hline هفت سال حبس & $1395 / 9 / 7$ & 1 & 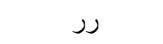 & 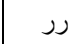 & נر & נر & 86 \\
\hline سه ماه حبس & $1395 / 11 / 3$ & 1 & 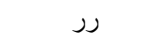 & 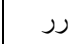 & رנ & נر - ل ار & 87 \\
\hline جهارماه حبس & $1395 / 11 / 12$ & 1 & 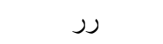 & 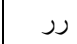 & נر & נر & 88 \\
\hline شش سال ودو ماه حبس & $1395 / 11 / 24$ & 1 & 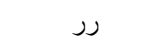 & נر & رر & נر & 89 \\
\hline بر ائت & $1395 / 9 / 28$ & 1 & خشونت & ميدان & ل كمّه & ديوان & 90 \\
\hline رد & $1395 / 11 / 23$ & 1 & رנر & & رد - ار & & 91 \\
\hline ده ماه حبس تنفيذى & $1395 / / 3 / 6$ & 1 & خشونت عليه زن & و ولايت & كوز كماس & ديوان & 92 \\
\hline 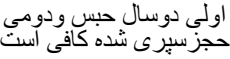 & $1395 / 7 / 8$ & 2 & لت وكوب & & 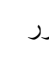 & & 93 \\
\hline
\end{tabular}

\section{6}




\section{قـضئ}

\begin{tabular}{|c|c|c|c|c|c|}
\hline دوسال حبس تتفيذى & $1395 / 8 / 17$ & 1 & ن ن نكاح زيرسن & 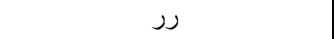 & 94 \\
\hline لينج سال يكماه حبس تنفيذى & $1395 / 9 / 11$ & 1 & ت تهديد & 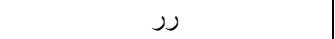 & 95 \\
\hline 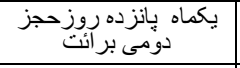 & $1395 / 11 / 2$ & 2 & 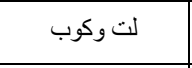 & 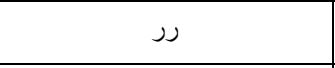 & 96 \\
\hline هشت ماه حبس تنفيذى & $1395 / 1 / 30$ & 1 & خشونت عليه زن & 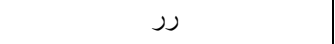 & 97 \\
\hline |يكسال ويكماه حبس تتفيذى & $1395 / 8 / 3$ & 1 & | ازدو اج غيرقانونى | & 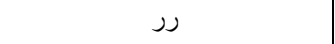 & 98 \\
\hline برائت & $1395 / 8 / 24$ & 1 & خود كثى & 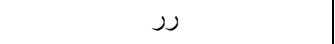 & 99 \\
\hline 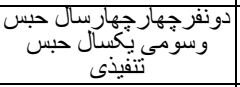 & $1395 / 6 / 1$ & 3 & مجروحيت & 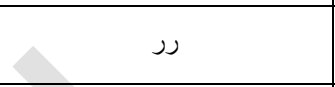 & 100 \\
\hline | شانزده سال حبس تتفيذى & $1395 / 2 / 25$ & 1 & لت وكوب & 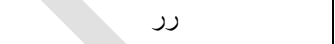 & 101 \\
\hline برى الذمه & $1395 / 4 / 23$ & 1 & 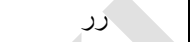 & ديوان جز اى محكمه استيناف يٍكتيا & 102 \\
\hline دونفربيست تُّنمه ويكى & $1395 / 6 / 1$ & 3 & ر ر اقدام به قتل & 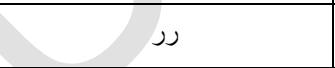 & 103 \\
\hline سهال ستفيذى سماه حبس & $1395 / 2 / 13$ & 1 & مجروحيت & ديوان جزاى استيناف و لايت كنر ها & 104 \\
\hline 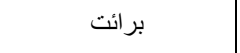 & $1395 / 8 / 10$ & 1 & נر & 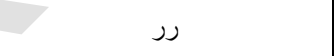 & 105 \\
\hline 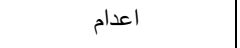 & 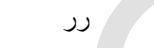 & 1 & خشونت منجربه قتل & 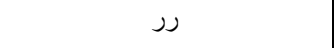 & 106 \\
\hline ينج سال حجز & $1395 / 8 / 7$ & 1 & 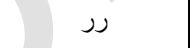 & 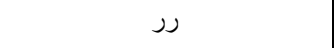 & 107 \\
\hline جريمه نقدى & $1395 / 11 / 25$ & 1 & مجروحيت & 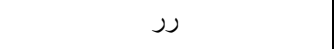 & 108 \\
\hline سه سه ماه حبس تنفيذى & $1395 / 12 / 3$ & 3 & مجروحيت & 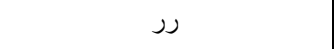 & 109 \\
\hline ينج سال حبس تنفبذى & $1395 / 10 / 7$ & 1 & 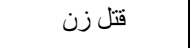 & ديو ان جز اى محكمه شهرى كنر ها & 110 \\
\hline يكماه حبس تتفيذى & $1395 / 11 / 3$ & 1 & ل لت وكوب & 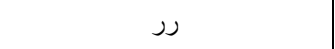 & 111 \\
\hline ينج سال ويكماه حبس & $1395 / 4 / 21$ & 1 & خشونت & ديوان جزاى محكمه استيناف و لايت & 112 \\
\hline يكسال حبس تنفيذى & $1395 / 10 / 26$ & 1 & נر & 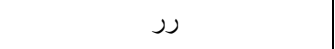 & 113 \\
\hline ينج سال ويكماه حبس & $1395 / 1 / 29$ & 1 & خشونت منجربه فوت & ديوان جزاى محكمه استيناف و لايت & 114 \\
\hline ده سال حبس تتفيذى & $1395 / 4 / 18$ & 1 & 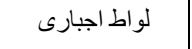 & 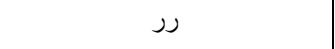 & 115 \\
\hline جريمه نقدى & $1395 / 4 / 6$ & 1 & 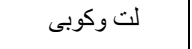 & נر & 116 \\
\hline برى الذمه & $1395 / 6 / 20$ & 1 & خشونت منجربه فوت & 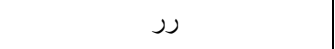 & 117 \\
\hline
\end{tabular}

\section{7}




\section{قاءخاء}

\begin{tabular}{|c|c|c|c|c|c|}
\hline بيست سال حبس تنفيذى & $1395 / 7 / 24$ & 1 & قتل & 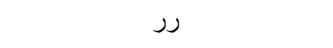 & 118 \\
\hline ده سال حبس تتفذى & $1395 / 9 / 4$ & 1 & مجروحيت & رر & 119 \\
\hline ينج سال ششماه حبس & נر & 1 & خشونت منجربقتل & 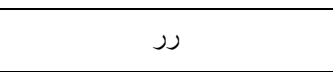 & 120 \\
\hline ايام سبرى شده كافى است & $1395 / 11 / 13$ & 1 & لت وكوب & 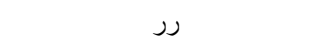 & 121 \\
\hline ينج سال ويكماه حبس & $1395 / 12 / 4$ & 1 & زنا اجبارى & 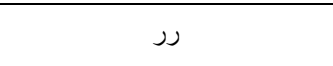 & 122 \\
\hline بنج سال وِيكماه حبس & $1395 / 1 / 29$ & 1 & خشونت & رנ & 123 \\
\hline شش سال حبس تنفيذى & $1395 / 9 / 14$ & 1 & 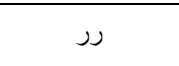 & ديو ان جزاى محكند استيناف و لايت & 124 \\
\hline بيست سال حبس تتفيذى & $1395 / 2 / 7$ & 2 & رر منجربقتل & 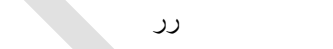 & 125 \\
\hline ينج سال ويكماه حبس & $1395 / 6 / 4$ & 3 & خشونت عليه زن & 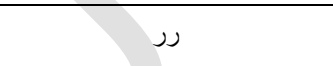 & 126 \\
\hline برى الذمه & $1395 / 1 / 17$ & 1 & از ازارو اذيت & ديوان جز اي محكمانه استيناف و لايت & 127 \\
\hline ينج سال ششئماه حبس & $1395 / 4 / 6$ & 1 & 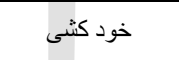 & נر - ت ا & 128 \\
\hline 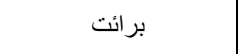 & $1395 / 5 / 20$ & 1 & قتل & $y$ & 129 \\
\hline ده سال حبس تتفيذى & $1395 / 5 / 24$ & 1 & قتل & נر & 130 \\
\hline يكنفربر ائت دوب ده سال & $1395 / 5 / 24$ & 2 & قتل & رנ & 131 \\
\hline سه سال حبس تنفيذى & $1395 / 7 / 6$ & 1 & مجروحيت & رد - ت ار & 132 \\
\hline هرو احد شانزده سال حبس & $1395 / 6 / 10$ & 2 & قتل & נر & 133 \\
\hline جهارماه حبس تنفيذى & $1395 / 6 / 16$ & 1 & مجروحيت & 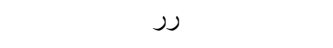 & 134 \\
\hline هز دهه سال حبس & $1395 / 7 / 13$ & 1 & قتل & رد - ت ار & 135 \\
\hline ششماه حبس تنفيذى & $1395 / 8 / 16$ & 1 & 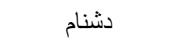 & رد - ت ار & 136 \\
\hline يكسال حبس تنفيذى & $1395 / 8 / 30$ & 1 & مجروحيت & 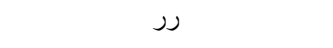 & 137 \\
\hline سه ماه حبس تنفيذى & $1395 / 9 / 17$ & 1 & خشونت عليه & رد & 138 \\
\hline جهار ماه حبس تنفيذى & $95 / 11 / 19$ & 1 & لت وكوب & رد & 139 \\
\hline 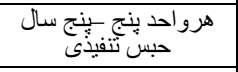 & $1395 / 2 / 29$ & 1 & خشونت وفعل زنا & ديوان جزاى محكمانه ابتدائيه شهرى & 140 \\
\hline سه ماه حبس تتفيذى & $1395 / 3 / 26$ & 1 & لت وكوب & 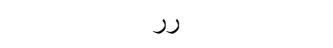 & 141 \\
\hline
\end{tabular}

\section{8}




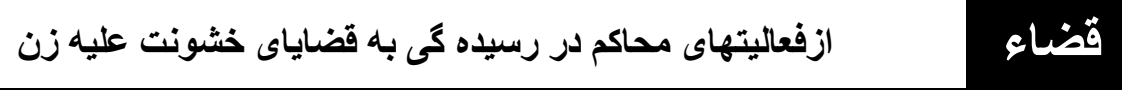

\begin{tabular}{|c|c|c|c|c|c|}
\hline سه سال حبس تنفيذى & $1395 / 4 / 6$ & 1 & خشونت & 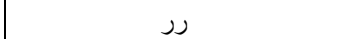 & 142 \\
\hline هرو احد دو - دو ماه حبس & $1395 / 5 / 10$ & 2 & 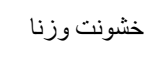 & 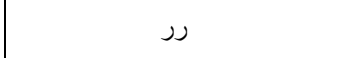 & 143 \\
\hline يكماه ويازدئى روز حبس & $1395 / 7 / 11$ & 1 & 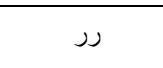 & 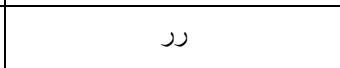 & 144 \\
\hline برى الذمه & $1395 / 8 / 2$ & 1 & قتل & رد - ل- ار & 145 \\
\hline يكسال حجز & $1395 / 8 / 2$ & 1 & خشونت فعل زنا & رد - ل- إ & 146 \\
\hline ششماه حجز & $1395 / 8 / 23$ & 1 & 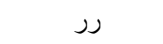 & رد - ل- إ & 147 \\
\hline ينج سال حبس تتفيذى & $1395 / 10 / 5$ & 1 & خشونت فعل زنا & رנر & 148 \\
\hline 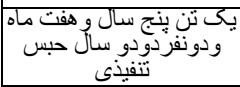 & $1395 / 10 / 26$ & 3 & رر منجر بقتل & 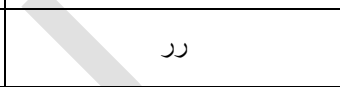 & 149 \\
\hline |بيست سال حبس تنفيذى | & $1395 / 11 / 10$ & 1 & 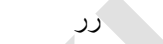 & 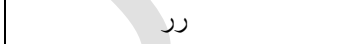 & 150 \\
\hline هزّده سال حبس تتفيذى & $1395 / 9 / 16$ & 1 & 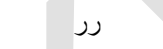 & محكمه ابتدائيه ولسو الى بكر ام برو ان & 151 \\
\hline هفده سال حبس تنفيذى & 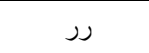 & 1 & 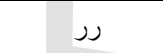 & 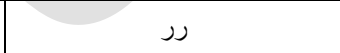 & 152 \\
\hline جهار ماه حبس تتفيذى & $1395 / 4 / 21$ & 1 & مجروحيت & 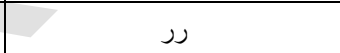 & 153 \\
\hline جهار ماه حبس تتفيذى & $1395 / 4 / 29$ & 1 & رנ & 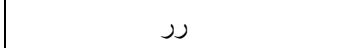 & 154 \\
\hline ينج سال ويكماه حبس & $1395 / 10 / 20$ & 1 & بددادن دختر & 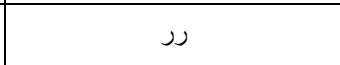 & 155 \\
\hline ايام سبرى شده كافى & $1395 / 1 / 24$ & 1 & خشونت عليه زن & ديو ان جز اى محكمه شهرى سمنكان & 156 \\
\hline جريمه نقدى & $1395 / 1 / 29$ & 1 & 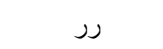 & 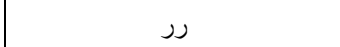 & 157 \\
\hline جريمه نقدى & $1395 / 3 / 11$ & 1 & 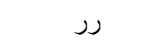 & 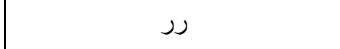 & 158 \\
\hline ايام سبرى شده كافى & $1395 / 3 / 9$ & 1 & 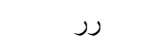 & 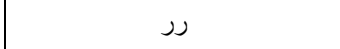 & 159 \\
\hline ايام سبِرى شده كافى & $1395 / 5 / 10$ & 1 & 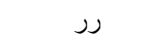 & 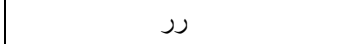 & 160 \\
\hline ايام سير شدى كافى & $1395 / 7 / 27$ & 1 & 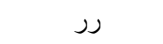 & 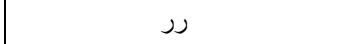 & 161 \\
\hline سه ماه حبس تتفيذى & $1395 / 7 / 20$ & 1 & رנ & رנ & 162 \\
\hline جريمه نقدى & $1395 / 9 / 2$ & 1 & رנ & رנ & 163 \\
\hline سه سال ششئى تُماه حبس & $1395 / 10 / 7$ & 1 & 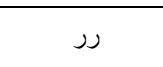 & 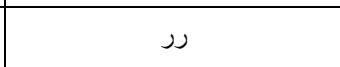 & 164 \\
\hline ده سال حبس تتفيذى & $1395 / 11 / 19$ & 1 & 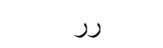 & 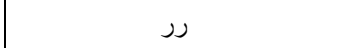 & 165 \\
\hline
\end{tabular}

\section{9}




\section{قـضئ}

\begin{tabular}{|c|c|c|c|c|c|}
\hline ده ماه حبس تنفيذى & $1395 / 4 / 9$ & 1 & خشونت & ديوان جزاى سحكمان استيناف ولايت & 166 \\
\hline جريمه نقدى & $1395 / 7 / 26$ & 1 & 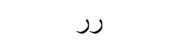 & 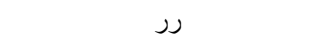 & 167 \\
\hline هرواحد جريمه نقدى & $1395 / 11 / 19$ & 3 & رد - ت ار & رد - ت ار & 168 \\
\hline برائت بر & $1395 / 8 / 5$ & 1 & 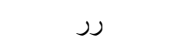 & 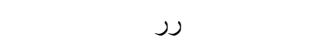 & 169 \\
\hline 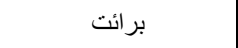 & $1395 / 11 / 4$ & 1 & خشونت & رد & 170 \\
\hline سه ماه حبس تنفيذى & $1395 / 1 / 15$ & 1 & لت وكوب & 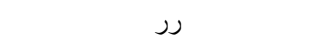 & 171 \\
\hline سه ماه حبس تتفيذى & $1395 / 2 / 28$ & 1 & 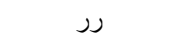 & 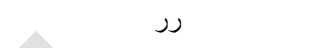 & 172 \\
\hline برائت بر & 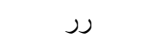 & 1 & 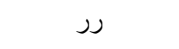 & رد - ت ار & 173 \\
\hline ششماه حبس تتفيذى & 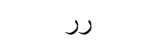 & 1 & 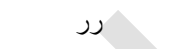 & رد - ت ار & 174 \\
\hline يكسال حبس تنفيذى & $1395 / 9 / 26$ & 1 & رנ & رد - ت ار & 175 \\
\hline جريمه نقدى & $1395 / 4 / 8$ & 1 & 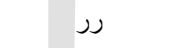 & 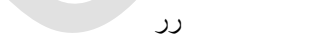 & 176 \\
\hline ايام سبرى شده كافى است & $1395 / 3 / 22$ & 1 & رر & $y$ & 177 \\
\hline رנ & $1395 / 4 / 30$ & 1 & 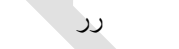 & נر & 178 \\
\hline ششماه حبس تتفيذى & $1395 / 5 / 13$ & 1 & رر & 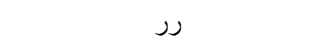 & 179 \\
\hline يكى بر ائت وديذيكرسه ماه & $1395 / 5 / 31$ & 2 & رر & رנ & 180 \\
\hline | ايام سبيرى شده كافى است & $1395 / 6 / 25$ & 1 & رנ & رנ & 181 \\
\hline جريمه نقدى & $1395 / 10 / 1$ & 1 & رر & رر & 182 \\
\hline سله سال وششئماه حبس & $1395 / 11 / 20$ & 1 & رر & رر & 183 \\
\hline 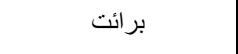 & $1395 / 8 / 9$ & 1 & رנ & رנ & 184 \\
\hline يازده سال حبس تنفيذى & $1395 / 1 / 32$ & 1 & رر & ديو ان جزاء محكمه ابتدائيه شهرى & 185 \\
\hline يانزده روزحبس تنفيذى & $1395 / 1 / 28$ & 1 & 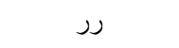 & 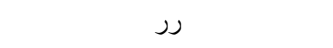 & 186 \\
\hline يكماه حبس تتفيذى & $1395 / 9 / 26$ & 1 & لت كوب & رנ & 187 \\
\hline يكماه حبس تتفيذى & $1395 / 2 / 13$ & 1 & 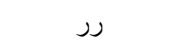 & 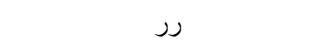 & 188 \\
\hline بيست سال حبس تنفيذى & $1395 / 2 / 23$ & 1 & ضرب منجربقتل & رد - ت ار & 189 \\
\hline
\end{tabular}




\section{قـضئ}

\begin{tabular}{|c|c|c|c|c|c|}
\hline سه ماه حبس تنفيذى & $1395 / 3 / 3$ & 1 & لت كوب & 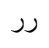 & 190 \\
\hline سه ماه حبس تتفيذى & 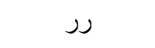 & 1 & 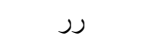 & 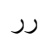 & 191 \\
\hline جهار ماه حبس تتفيذى & $1395 / 5 / 31$ & 2 & رد - ت ار & رد - ت ار & 192 \\
\hline ششماه حبس تتفيذى & $1395 / 6 / 25$ & 1 & נر & 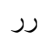 & 193 \\
\hline رد - ت ار & $1395 / 10 / 1$ & 1 & 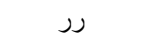 & נر - ت ا & 194 \\
\hline سه ماه حبس تنفيذى & $1395 / 11 / 20$ & 1 & 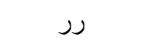 & رد - ت إ & 195 \\
\hline سه ماه حبس تتفيذى & $1395 / 8 / 9$ & 1 & 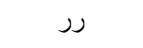 & رנ & 196 \\
\hline ده سال حبس تتفيذى & $1395 / 1 / 8$ & 2 & خو دكثى & 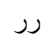 & 197 \\
\hline دوماه حبس تتفيذى & $1395 / 1 / 32$ & 2 & 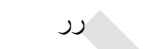 & 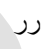 & 198 \\
\hline ششماه حبس تنفيذى & $1395 / 1 / 26$ & 1 & آزار و اذيت & 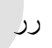 & 199 \\
\hline يكسال وشيشّماه حبس & $/ 1 / 28$ & 1 & נر & 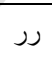 & 200 \\
\hline الى ينج سال حبس تتفيذى & $1395 / 2 / 13$ & 1 & لت وكوب & 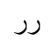 & 201 \\
\hline ششماه حبس تنفيذى & $1395 / 2 / 15$ & 1 & رر & 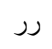 & 202 \\
\hline ششماه حبس تتفيذى & $1395 / 2 / 23$ & 1 & ضربوجرح & 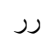 & 203 \\
\hline يكماه حبس تتفيذى & $1395 / 3 / 11$ & 1 & قتل & 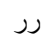 & 204 \\
\hline ينج ماه حبس تنفيذى & $1395 / 3 / 22$ & 1 & لت وكوب & رر & 205 \\
\hline جهار ماه حبس تتفيذى & ر & 1 & رر - ت ا & נر & 206 \\
\hline ششماه حبس تتفيذى & $1395 / 4 / 6$ & 1 & لت وكوب & 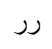 & 207 \\
\hline ششماه حبس تنفيذى & $1395 / 4 / 9$ & 1 & נر & رנ & 208 \\
\hline سه ماه حبس تنفيذى & رנ & 1 & נر & رנ & 209 \\
\hline سه ماه حبس تنفيذى & $1395 / 5 / 7$ & 1 & آزارو اذيت & رد & 210 \\
\hline ده سال حبس تنفيذى & $1395 / 5 / 14$ & 1 & قتل & رנ & 211 \\
\hline دوماه حبس تتفيذى & $1395 / 5 / 16$ & 1 & لت وكوبى & رנ & 212 \\
\hline شش ماه حبس تتفيذى & $1395 / 5 / 20$ & 1 & 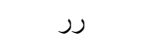 & رر & 213 \\
\hline
\end{tabular}




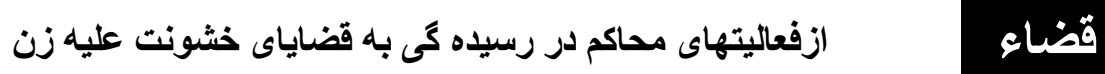

\begin{tabular}{|c|c|c|c|c|c|}
\hline ويكنفربر ائت حبس ششماه تنفيذى & 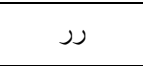 & 2 & خود كثى & נر & 214 \\
\hline الى ينج سال حبس تنفيذى & $1395 / 5 / 24$ & 3 & 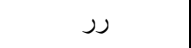 & 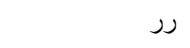 & 215 \\
\hline ششماه حبس تتفيذى & رد - ت ار & 1 & لت وكوب & 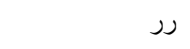 & 216 \\
\hline ششماه حبس تتفيذى & $1395 / 6 / 15$ & 1 & נر & 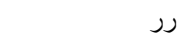 & 217 \\
\hline يكماه حبس تتفيذى & $1395 / 7 / 4$ & 1 & تهديد & 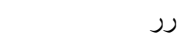 & 218 \\
\hline ششماه حبس تنفيذى & $1395 / 7 / 8$ & 1 & لت وكوب & رد - ت ار & 219 \\
\hline يكماه حبس تتفيذى & $1395 / 7 / 10$ & 1 & 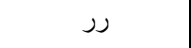 & 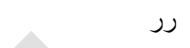 & 220 \\
\hline يكماه حبس تتفيذى & $1395 / 7 / 18$ & 1 & لت وكوب & 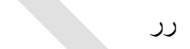 & 221 \\
\hline هرو احد يكسال وششماه تنفيذى & $1395 / 7 / 20$ & 2 & تهديد & 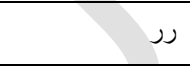 & 222 \\
\hline برائت & $1395 / 7 / 22$ & 1 & | از ازدواجزيرسن & 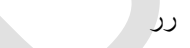 & 223 \\
\hline جريمه نقدى & $1395 / 7 / 26$ & 1 & لت وكوب & 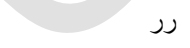 & 224 \\
\hline يكسال سه ماه حبس تتفيذى & $1395 / 8 / 4$ & 1 & ر & رد - ت ار & 225 \\
\hline دوماه حبس تتفيذى & נر & 1 & رנ & 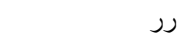 & 226 \\
\hline هرو احد سفه ماه حبس & $1395 / 8 / 10$ & 2 & هتك حرمت & رנ - ت ا & 227 \\
\hline سه سال حبس تنفيذى & $1395 / 8 / 11$ & 1 & مجروحيت & 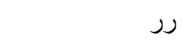 & 228 \\
\hline ده ماه حبس تتفيذى & $1395 / 8 / 16$ & 1 & لت وكوب & 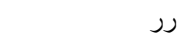 & 229 \\
\hline يكسال حبس تنفيذى & $1395 / 8 / 20$ & 1 & مجروحيت & رر & 230 \\
\hline 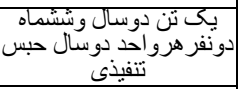 & $1395 / 9 / 16$ & 3 & لت وكوب & رر & 231 \\
\hline برى الذهـ & $1395 / 9 / 20$ & 1 & آزارو اذيت & 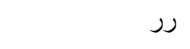 & 232 \\
\hline بيست سال حبس تنفيذى & $1395 / 9 / 23$ & 1 & قتل & 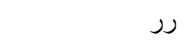 & 233 \\
\hline ششماه حبس تنفيذى & 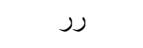 & 1 & آتش زدن & 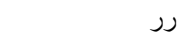 & 234 \\
\hline سه ماه حبس تتفيذى & 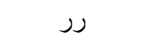 & 1 & لت كوب & 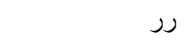 & 235 \\
\hline سه ماه حبس تتفيذى & $1395 / 9 / 24$ & 1 & اقدام به آتش زدن & 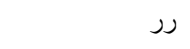 & 236 \\
\hline يكي سهر سال نقبس & $1395 / 9 / 28$ & 2 & ضرب منجربه فوت & 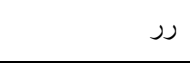 & 237 \\
\hline
\end{tabular}




\section{قـضئ}

\begin{tabular}{|c|c|c|c|c|c|}
\hline ششماه حبس تتفيذى & 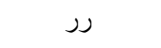 & 1 & تهديد & رد & 238 \\
\hline برى الذهه & $1395 / 11 / 4$ & 1 & ازدواج اجبارى & 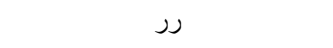 & 239 \\
\hline سه ماه حبس تتفيذى & $1395 / 11 / 10$ & 1 & آز اروو اذيت & 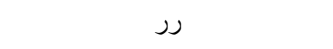 & 240 \\
\hline برائت & $1395 / 11 / 12$ & 2 & منجربقتل & رد & 241 \\
\hline يكماه حبس تتفيذى & $1395 / 11 / 25$ & 1 & لت كوب & رد & 242 \\
\hline سه سال حبس تنفيذى & $1395 / 7 / 27$ & 1 & آزارو اذيت & ديوان جزاى محكمه استيناف ولايت & 243 \\
\hline | يكنفربر ائت ديكرجريمه & $1395 / 8 / 4$ & 2 & خو دكثى & رנ & 244 \\
\hline يكسال حبس تنفيذى & $1395 / 8 / 15$ & 1 & دخترخورد سن & رנ & 245 \\
\hline جريمه نقدى & $1395 / 9 / 6$ & 2 & لت كوب & رנ & 246 \\
\hline يكسال حبس تنفيذى & $1395 / 9 / 28$ & 1 & ازارو اذيت & 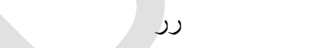 & 247 \\
\hline جريمه نقدى & $1395 / 10 / 4$ & 1 & خود كثى & رر & 248 \\
\hline بنجسال وششيماه حبس & $1395 / 10 / 18$ & 1 & سمجربورتى منى & رנ & 249 \\
\hline 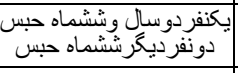 & נر & 3 & ل لت كوب & رנ & 250 \\
\hline ششماه حبس تنفيذى & رנ & 1 & تهديد & رנ & 251 \\
\hline دوماه حبس تتفيذى & 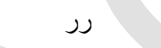 & 1 & اقدام به آتش زدن & رد & 252 \\
\hline برائت & $1395 / 10 / 21$ & 1 & آزار و اذيت & رر & 253 \\
\hline برائت & $1395 / 10 / 25$ & 1 & مسموميت منجربفوت| & رر & 254 \\
\hline ششماه حبس تنفيذى & $1395 / 10 / 26$ & 1 & خود سوزى & رر & 255 \\
\hline سه ماه حبس تنفيذى & $1395 / 1 / 7$ & 1 & נر & נر & 256 \\
\hline بكنفزينجى دومى و بكمائت حبس & $1395 / 1 / 9$ & 2 & خودكثى & رر & 257 \\
\hline جهارماه حبس تتفيذى & $1395 / 1 / 16$ & 1 & لت كوب & رد & 258 \\
\hline سه ماه حبس تنفيذى & נر & 1 & נر & נر & 259 \\
\hline بكسال حبس تتفيذى & رנ & 1 & آزارو اذيت & رد & 260 \\
\hline يكسال حبس تنفيذى & $1395 / 1 / 18$ & 1 & خود سوزى & 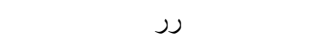 & 261 \\
\hline
\end{tabular}




\section{قـضئ}

\begin{tabular}{|c|c|c|c|c|c|}
\hline دوسال وشنشماه حبس & נر & 1 & خو دكشى & נر & 262 \\
\hline ششماه حبس تتفيذى & $1395 / 3 / 10$ & 1 & خو دكثى & 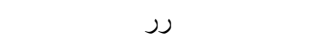 & 263 \\
\hline ششماه حبس تنفيذى & $1395 / 3 / 29$ & 1 & 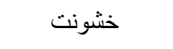 & 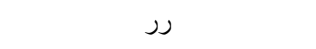 & 264 \\
\hline سه ماه حبس نفيذى & $1395 / 4 / 24$ & 1 & آز ارو اذيت & 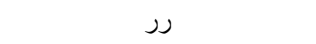 & 265 \\
\hline 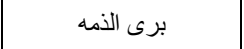 & 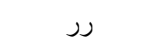 & 1 & مسموميت & נر & 266 \\
\hline يكماه و هفتئى روزحبس & $1395 / 4 / 28$ & 1 & آز ارو اذيت & נر & 267 \\
\hline يكماه حبس تنفيذى & $1395 / 4 / 29$ & 1 & 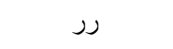 & 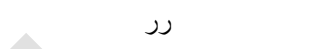 & 268 \\
\hline هرو احد دوسيال حبس & رد & 2 & خودسوزى & נر & 269 \\
\hline ششماه حبس تتفيذى & $1395 / 5 / 18$ & 1 & آز ارو آذيت & 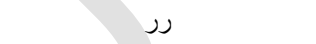 & 270 \\
\hline 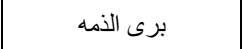 & $1395 / 5 / 24$ & 1 & سوختخى & נر & 271 \\
\hline 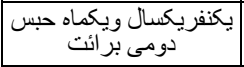 & $1395 / 6 / 3$ & 2 & خو دكشى & 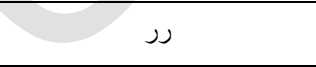 & 272 \\
\hline ششماه حبس تنفيذى & $1395 / 6 / 9$ & 1 & آزارواذيت & رנ & 273 \\
\hline ششماه حبس تنفيذى & $1395 / 6 / 16$ & 1 & لت وكوب & נر & 274 \\
\hline يكسال حبس تنفيذى & رנ & 1 & خشونت منجربقتل & 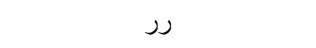 & 275 \\
\hline ينج سال ويكما حبس & 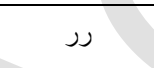 & 1 & خودسوزى & 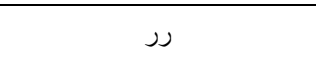 & 276 \\
\hline سه ماه حبس تتفيذى & رנ & 1 & 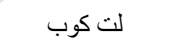 & נر & 277 \\
\hline 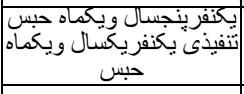 & $1395 / 7 / 11$ & 2 & خو دكثى & נر & 278 \\
\hline جريمه نقدى & $1395 / 7 / 12$ & 1 & لت كوب & 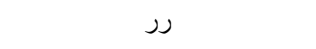 & 279 \\
\hline 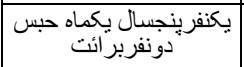 & $1395 / 1 / 30$ & 3 & 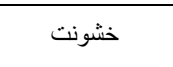 & ديو ان جزا محكمه استيناف و لايت & 280 \\
\hline يكسال وششماه حبس & $1395 / 11 / 16$ & 1 & נر & נر & 281 \\
\hline يكنفريذي وديكر وبشرائت حبس & $1395 / 11 / 7$ & 2 & נر & ل- إر & 282 \\
\hline يكنفر هفت سال ودوبس تنفيذى & $1395 / 5 / 23$ & 2 & رנ & ديوان جزاى محكمه شهرى غور & 283 \\
\hline يكسال ويكماه حبس تتفيذى | & $1395 / 10 / 7$ & 2 & رנ & رد - ت ار & 284 \\
\hline 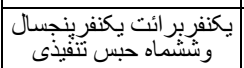 & 1395/10/19 & 2 & رנ & محكمه ابتدائيه لعل سرجنكل غور & 285 \\
\hline
\end{tabular}




\section{قـضئ}

\begin{tabular}{|c|c|c|c|c|c|}
\hline برائت & $1395 / 11 / 27$ & 1 & 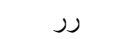 & 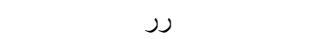 & 286 \\
\hline سه ماه حبس تنفيذى & $1395 / 1 / 27$ & 1 & خشونت & ديو ان جزاى استيناف دايكندى & 287 \\
\hline يكماه حبس تنفيذى & 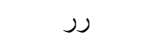 & 1 & رد - تا & رد - ت ار & 288 \\
\hline جريمه نقدى & $1395 / 1 / 22$ & 1 & 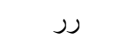 & 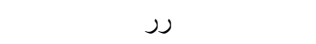 & 289 \\
\hline سه ماه حبس تنفيذى & $1395 / 2 / 20$ & 1 & 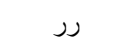 & 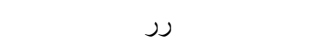 & 290 \\
\hline جريمه نقدى & $1395 / 3 / 3$ & 1 & 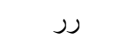 & 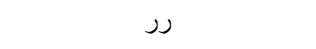 & 291 \\
\hline جريمه نقدى & $1395 / 3 / 25$ & 1 & رد - تا & رد & 292 \\
\hline جريمه نقدى & $1395 / 5 / 10$ & 2 & رد - ل- ار & 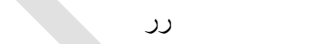 & 293 \\
\hline جريمه نقدى & $1395 / 5 / 12$ & 1 & ر & ر - تار & 294 \\
\hline جريمه نقدى & $1395 / 5 / 26$ & 1 & رر & رد - تا & 295 \\
\hline يكنفر ستف ماه حبس & $1395 / 6 / 2$ & 2 & 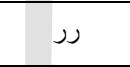 & 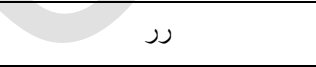 & 296 \\
\hline جريمه نقدى & $1395 / 6 / 11$ & 3 & נر & 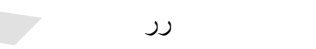 & 297 \\
\hline دوماه حبس تتفيذى & $1395 / 6 / 11$ & 1 & لت كوب & 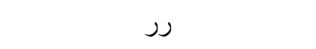 & 298 \\
\hline يكماه ويانز دهذ روزحبس & $1395 / 7 / 24$ & 1 & נر & 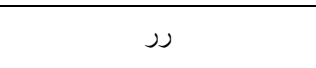 & 299 \\
\hline جريمه نقدى & $95 / 7 / 27$ & 2 & رد - تار & 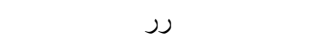 & 300 \\
\hline جريمه نقدى & $1395 / 8 / 15$ & 1 & 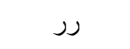 & 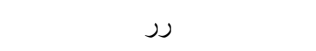 & 301 \\
\hline سه سال حجز & $1395 / 8 / 25$ & 1 & خو دكثى & 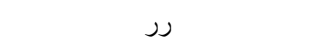 & 302 \\
\hline سه ماه حجز & $1395 / 9 / 2$ & 1 & لت وكوب & 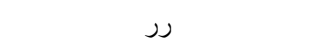 & 303 \\
\hline هرو احد سنه ماه حبس & $1395 / 11 / 19$ & 2 & فحش ودشنام & 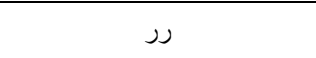 & 304 \\
\hline جهارماه حبس تنفيذى & $1395 / 12 / 2$ & 1 & 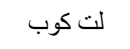 & 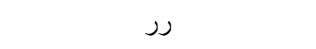 & 305 \\
\hline هرواحد جريمه نقدى & $1395 / 8 / 18$ & 4 & 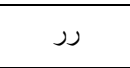 & محكمه ابتدائيه سنكتختى & 306 \\
\hline جريمه نقدى & $1395 / 9 / 27$ & 1 & 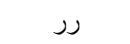 & 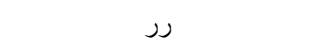 & 307 \\
\hline جريمه نقدى & $1395 / 10 / 29$ & 1 & 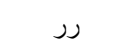 & 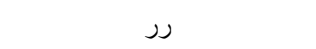 & 308 \\
\hline جريمه نقدى & $1395 / 3 / 4$ & 1 & رر & محكمه ابتدائيه شهرستان دايكندى & 309 \\
\hline
\end{tabular}




\section{قـضئ}

\begin{tabular}{|c|c|c|c|c|c|}
\hline هرو احد جريمه نقدى & $1395 / 3 / 31$ & 2 & رد & رد - ت ار & 310 \\
\hline هرو احد جريمه نقدى & $1395 / 4 / 28$ & 4 & 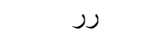 & 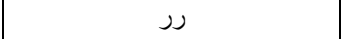 & 311 \\
\hline هرو احد جريمه نقدى & $1395 / 5 / 13$ & 3 & 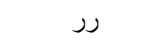 & رد - ت ار & 312 \\
\hline هرو احد جريمه نقدى & $1395 / 7 / 17$ & 2 & 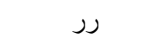 & رد & 313 \\
\hline جريمه نقدى & $1395 / 10 / 12$ & 1 & 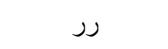 & 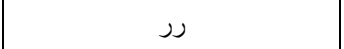 & 314 \\
\hline هرو احد جريمه نقدى & $1395 / 10 / 13$ & 2 & 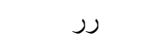 & 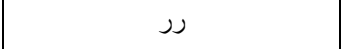 & 315 \\
\hline جريمه نقدى & $1395 / 10 / 14$ & 1 & נر & 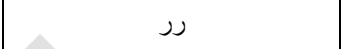 & 316 \\
\hline جهار ماه حبس تتفيذى & $1395 / 11 / 11$ & 1 & 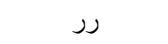 & 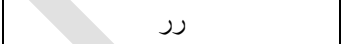 & 317 \\
\hline سه ماه حبس تنفيذى & $1395 / 11 / 19$ & 1 & رد & رر & 318 \\
\hline هرو احد جريمه نقدى & $1395 / 11 / 23$ & 3 & رנ & 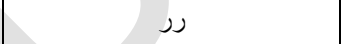 & 319 \\
\hline هرو احد جريمه نقدى & $1395 / 11 / 27$ & 2 & 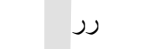 & 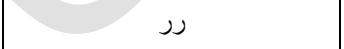 & 320 \\
\hline دوماه حبس تنفيذى & $1395 / 5 / 18$ & 1 & 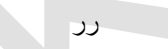 & ديوان جز امحكمه شهرى دايكندى & 321 \\
\hline سه ماه حبس ثتفيذى & $1395 / 6 / 31$ & 1 & 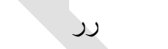 & 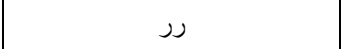 & 322 \\
\hline هرو احد جريمه نقدى & 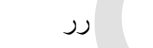 & 2 & 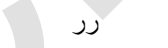 & 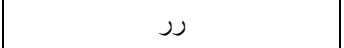 & 323 \\
\hline جريمه نقدى & $1395 / 7 / 11$ & 1 & 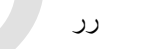 & 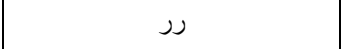 & 324 \\
\hline جهارسال حبس تتفيذى & $1395 / 7 / 28$ & 1 & منجربفوت & 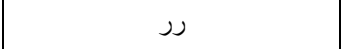 & 325 \\
\hline هرو احد جريمه نقدى & $1395 / 8 / 22$ & 2 & خشونت لت كوب & رر & 326 \\
\hline هرو احد جريمه نقدى & $1395 / 10 / 15$ & 2 & נر - ت ا & 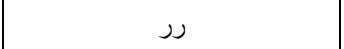 & 327 \\
\hline دوسال حبس تتفيذى & $1395 / 2 / 11$ & 1 & 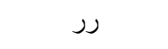 & محكمه ابتدائيه ولسو الى كيتى دايكندى & 328 \\
\hline بيست روزحبس تنفيذى & $1395 / 3 / 1$ & 1 & 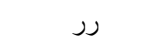 & 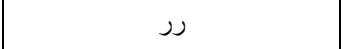 & 329 \\
\hline هرو احد جريمه نقدى & $1395 / 6 / 8$ & 2 & 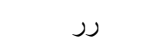 & 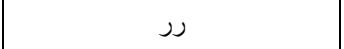 & 330 \\
\hline يكماه حبس تتفيذى & $1395 / 7 / 17$ & 1 & 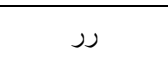 & محكماه ابتدائيه ولسكنو الىى & 331 \\
\hline سه ماه حبس تنفيذى & $1395 / 8 / 16$ & 1 & 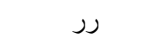 & رد - ت ار & 332 \\
\hline دونفر يكى بـ بـ ماه حبس & $1395 / 8 / 18$ & 3 & 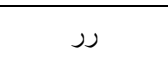 & 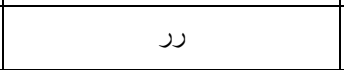 & 333 \\
\hline
\end{tabular}




\section{قـضئ}

\begin{tabular}{|c|c|c|c|c|c|}
\hline هرو احد جريمه نقدى & $1395 / 8 / 15$ & 3 & 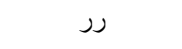 & 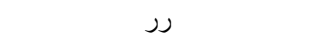 & 334 \\
\hline هرو احد جريمه نقدى & $1395 / 10 / 18$ & 2 & 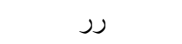 & رد - ت ار & 335 \\
\hline جهارماه حبس تتفيذى & $1395 / 10 / 27$ & 1 & 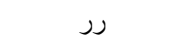 & 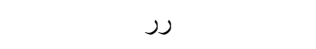 & 336 \\
\hline يكنفرجنار ماهت حبس & $1395 / 11 / 9$ & 2 & 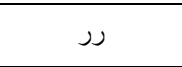 & 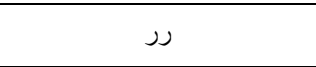 & 337 \\
\hline هرو احد جريمه نقدى & $1395 / 12 / 8$ & 2 & 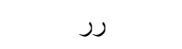 & נر & 338 \\
\hline جريمه نقدى & $1395 / 1 / 16$ & 1 & 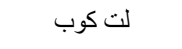 & ديو ان جزاى محكمه استيناف كندز & 339 \\
\hline بيست سال حبس تنفذى & $1395 / 3 / 8$ & 1 & قتل & 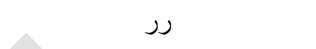 & 340 \\
\hline بكنيم ماه حبس تنفيذى & $1395 / 8 / 22$ & 1 & 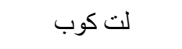 & 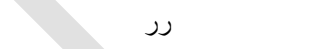 & 341 \\
\hline شانزده سال حبس تنفيذى & נر & 1 & 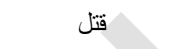 & 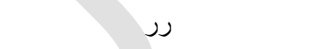 & 342 \\
\hline سه ماه حبس تتفيذى & $1395 / 9 / 6$ & 1 & ل لت كوب & 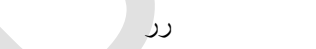 & 343 \\
\hline سه ماه حبس تتفيذى & $1395 / 9 / 6$ & 1 & ت تهديد & 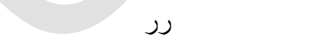 & 344 \\
\hline جهارسال حبس تنفيذى & 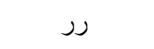 & 1 & 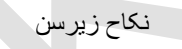 & 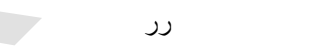 & 345 \\
\hline جهارسال حبس تتفيذى & 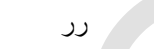 & 1 & 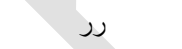 & נر & 346 \\
\hline سه ماه حبس تتفيذى & $1395 / 9 / 17$ & 1 & آزار و اذيت & رנ & 347 \\
\hline سه ماه حبس تتفيذى & $1395 / 9 / 27$ & 1 & ل لت كوب & 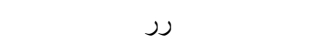 & 348 \\
\hline دوماه حبس تتفيذى & $1395 / 10 / 21$ & 1 & 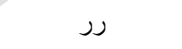 & 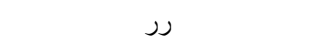 & 349 \\
\hline شانزده سال حبس تتفيذى & $1395 / 11 / 23$ & 1 & قتل & 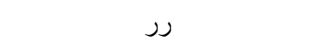 & 350 \\
\hline هفده سال حبس تنفيذى & $1395 / 2 / 7$ & 1 & قتل & ديو ان جز اى محكمه شهرى كندز & 351 \\
\hline ششماه حبس تتفيذى & $1395 / 6 / 31$ & 1 & ل لت وكوب & 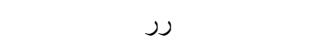 & 352 \\
\hline جريمه نقدى & $1395 / 7 / 3$ & 1 & 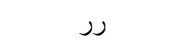 & 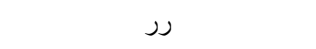 & 353 \\
\hline ششماه حبس تنفيذى & $1395 / 8 / 8$ & 1 & 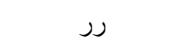 & 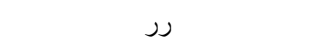 & 354 \\
\hline سه ماه حبس تتفيذى & נر & 1 & 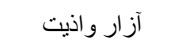 & 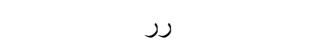 & 355 \\
\hline سه ماه حبس تتفيذى & 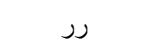 & 1 & ت تهديد & ل در & 356 \\
\hline هرو احس ينج ستفالّ ويكماه & 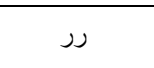 & 2 & خريد وفروش زن & נر & 357 \\
\hline
\end{tabular}




\section{قـضئ}

\begin{tabular}{|c|c|c|c|c|c|}
\hline سه ماه حبس تتفيذى & $1395 / 8 / 11$ & 1 & لت وكوب & رנ & 358 \\
\hline 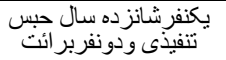 & $1395 / 10 / 28$ & 3 & قتل & رנ & 359 \\
\hline شش سال حبس تنفيذى & $1395 / 4 / 5$ & 1 & قتل & 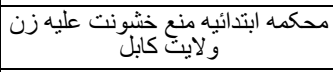 & 360 \\
\hline اشد مجازات & $1395 / 4 / 8$ & 1 & رد & رد & 361 \\
\hline هز ده سال حبس تتفيذى & $1395 / 7 / 5$ & 1 & رر & رد & 362 \\
\hline اثند مجازات & 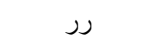 & 1 & رد & رد & 363 \\
\hline برى الذمه & $1395 / 7 / 12$ & 1 & رد & رد & 364 \\
\hline اشد مجاز ات & $1395 / 7 / 26$ & 1 & رر & נر & 365 \\
\hline هرو احت سفيذه سال حبس & $1395 / 2 / 9$ & 2 & رد & رر & 366 \\
\hline برى الذمه & $1395 / 9 / 2$ & 2 & قتل & 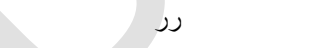 & 367 \\
\hline 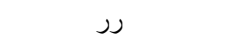 & $1395 / 7 / 5$ & 1 & 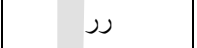 & 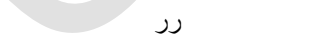 & 368 \\
\hline رد & $139 / 3 / 30$ & 2 & رנ & $y$ & 369 \\
\hline اشد مجاز ات & $1395 / 11 / 18$ & 1 & رد - ت ار & رد & 370 \\
\hline برى الذها & $1395 / 11 / 25$ & 1 & رد & رر & 371 \\
\hline بيست سال حبس تتفيذى & $1395 / 12 / 16$ & 1 & 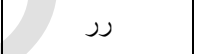 & رر & 372 \\
\hline برى الذها & $1395 / 10 / 27$ & 1 & خو دسوزى منجر بقتل | & رر & 373 \\
\hline جهار سال حبس تنفيذى & $1395 / 10 / 13$ & 1 & رر & رر & 374 \\
\hline برى الذمه & $1395 / 5 / 18$ & 1 & رر - ت ا & رد & 375 \\
\hline اشد مجاز ات & $1395 / 10 / 13$ & 1 & | سوختاندن منجربه & رנ & 376 \\
\hline ينج سال حبس تتفيذى & $1395 / 10 / 27$ & 1 & خو نشى & 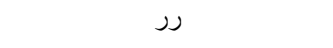 & 377 \\
\hline برى الذهـ & رد & 1 & رد & رد & 378 \\
\hline נر & $1395 / 5 / 11$ & 1 & נر & رנ & 379 \\
\hline ينجسال حبس تتفيذى & $1395 / 6 / 8$ & 1 & رנ & رנ & 380 \\
\hline برى الذهه & $1395 / 7 / 12$ & 1 & رנ & رر & 381 \\
\hline
\end{tabular}




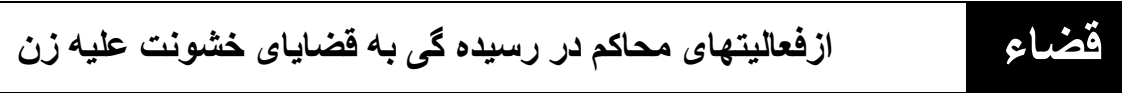

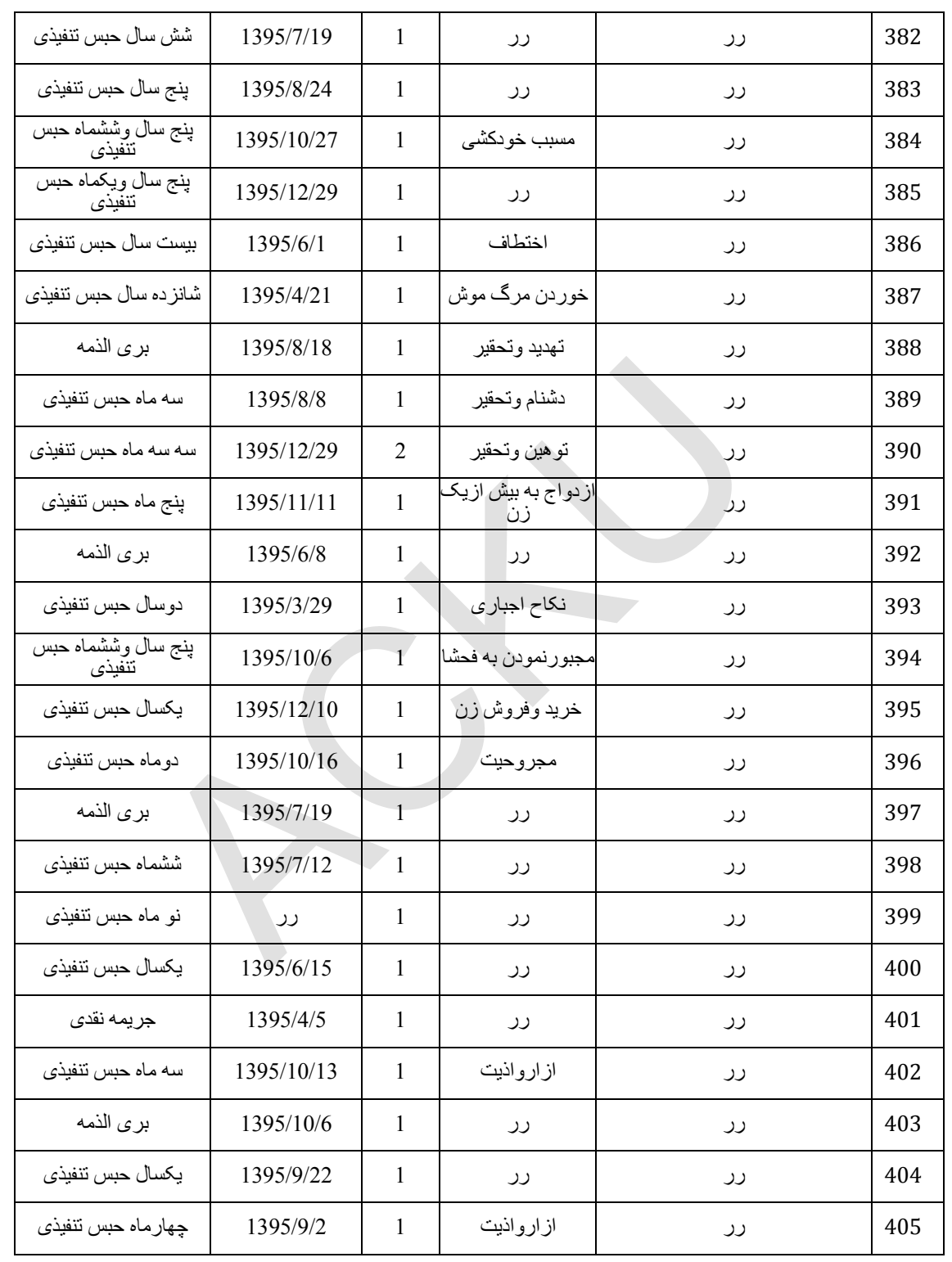




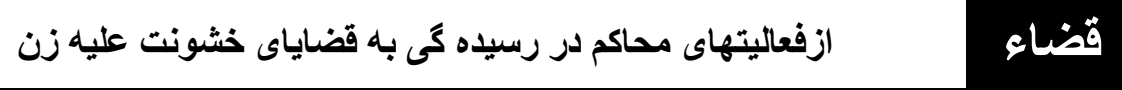

\begin{tabular}{|c|c|c|c|c|c|}
\hline سه ماه حبس تتفيذى & $1395 / 5 / 16$ & 1 & 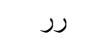 & נر & 406 \\
\hline جهارماه حبس تتفيذى & $1395 / 5 / 10$ & 1 & 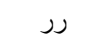 & 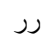 & 407 \\
\hline رد & $1395 / 11 / 9$ & 1 & رد - ت ار & 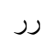 & 408 \\
\hline ششماه حبس تتفيذى & $1395 / 12 / 10$ & 1 & נر & נر & 409 \\
\hline سه ماه حب تتفيذى & $1395 / 12 / 29$ & 1 & رر & رد & 410 \\
\hline برى الذهـ & $1395 / 4 / 22$ & 1 & لت كوب & 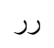 & 411 \\
\hline رد & $1395 / 4 / 21$ & 2 & رנ & נر & 412 \\
\hline رد & $1395 / 4 / 8$ & 4 & 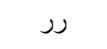 & 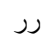 & 413 \\
\hline رد & $1395 / 4 / 7$ & 1 & رد & رد & 414 \\
\hline جريمه نقدى & נر - ت ت & 1 & נر & 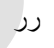 & 415 \\
\hline يكماه حبس تتفيذى & $1395 / 4 / 13$ & 1 & 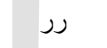 & 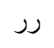 & 416 \\
\hline حبس كنثنه كافى است & 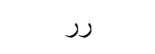 & 1 & رנ & 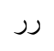 & 417 \\
\hline رر & $1395 / 4 / 5$ & 1 & رد - ت ار & رد - ت ار & 418 \\
\hline دوماه حبس تتفيذى & $1395 / 3 / 3$ & 1 & رد - ل ت & رد - ت ار & 419 \\
\hline נر & $1395 / 3 / 30$ & 2 & 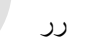 & رد - ت ا & 420 \\
\hline جريمه نقدى & $1395 / 10 / 28$ & 1 & رر & رد - ت ار & 421 \\
\hline دوماه حبس تتفيذى & $1395 / 11 / 2$ & 1 & رر & رر & 422 \\
\hline سه ماه حبس تتفيذى & $1395 / 11 / 4$ & 1 & 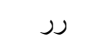 & 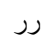 & 423 \\
\hline נر & $1395 / 11 / 11$ & 1 & נر & 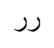 & 424 \\
\hline נر & $1395 / 11 / 18$ & 1 & رנ & 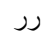 & 425 \\
\hline برى الذهـ & $1395 / 11 / 19$ & 1 & رנ & 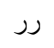 & 426 \\
\hline נر & $1395 / 12 / 10$ & 1 & נر & נر & 427 \\
\hline يكماه حبس تتفيذى & $1395 / 12 / 17$ & 1 & 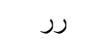 & رد & 428 \\
\hline ششماه حبس تنفيذى & 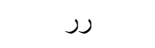 & 1 & 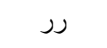 & 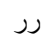 & 429 \\
\hline
\end{tabular}




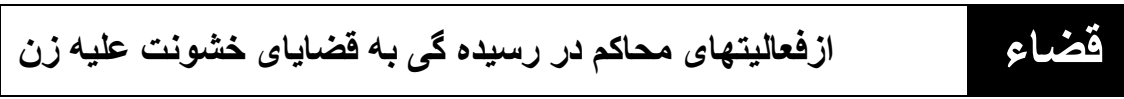

\begin{tabular}{|c|c|c|c|c|c|}
\hline سه ماه حبس تتفيذى & $1395 / 11 / 2$ & 1 & 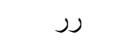 & رנ & 430 \\
\hline دوماه حبس تتفيذى & $1395 / 4 / 29$ & 1 & 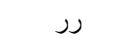 & رנ & 431 \\
\hline سه ماه حبس تتفيذى & $1395 / 10 / 27$ & 1 & رد & رנ & 432 \\
\hline جريمه نقدى & $1395 / 10 / 20$ & 2 & נر & رנ & 433 \\
\hline حبس كنشته كافى است & $1395 / 10 / 6$ & 1 & رנ & رנ & 434 \\
\hline سه ماه حبس تنفيذى & $1395 / 10 / 4$ & 1 & رد & رנ & 435 \\
\hline رد & $1395 / 9 / 2$ & 1 & رد & رנ & 436 \\
\hline برى الذها & $1395 / 8 / 17$ & 1 & 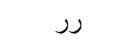 & رנ & 437 \\
\hline رנ & رد - ت ا & 1 & رد & رנر & 438 \\
\hline נر & $1395 / 9 / 24$ & 1 & נر & رנ & 439 \\
\hline برى الذهه & $1395 / 7 / 19$ & 1 & لت وكوب & 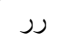 & 440 \\
\hline دو ماه حبس تتفيذى & $1395 / 9 / 15$ & 1 & رر & رנ & 441 \\
\hline يكسال حبس تنفيذى & $1395 / 9 / 7$ & 1 & رد - ت ار & رد & 442 \\
\hline ششماه حبس تتفيذى & $1395 / 7 / 4$ & 1 & رנ & رנ & 443 \\
\hline 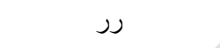 & $1395 / 7 / 28$ & 1 & 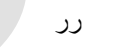 & رנ & 444 \\
\hline جريمه نقدى & $1395 / 7 / 26$ & 1 & رر & رر & 445 \\
\hline يكماه حبس تتفيذى & $1395 / 7 / 26$ & 1 & נر & رد & 446 \\
\hline سه ماه حبس تتفيذى & $1395 / 7 / 19$ & 1 & رد & رנ & 447 \\
\hline נر & $1395 / 7 / 14$ & 1 & נر & رנ & 448 \\
\hline جريمه نقدى & $1395 / 7 / 12$ & 1 & رנ & رנ & 449 \\
\hline برى الذمه & $1395 / 7 / 6$ & 1 & رد & رנ & 450 \\
\hline جريمه نقدى & $1395 / 7 / 5$ & 1 & رد & رد & 451 \\
\hline حبس كنشته كافى است & נر & 1 & נر & رנ & 452 \\
\hline جريمه نقدى & $1395 / 6 / 31$ & 1 & 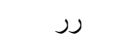 & رر & 453 \\
\hline
\end{tabular}




\section{قـضئ}

\begin{tabular}{|c|c|c|c|c|c|}
\hline دو ماه حبس تتفيذى & $1395 / 9 / 15$ & 1 & رد & 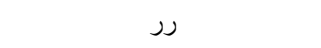 & 454 \\
\hline سه ماه حبس تنفيذى & $1395 / 6 / 8$ & 1 & 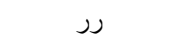 & 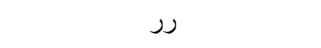 & 455 \\
\hline 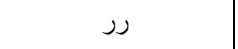 & رد - ت ار & 1 & رد - ت ار & رد - ت ار & 456 \\
\hline رנ & $1395 / 6 / 1$ & 1 & 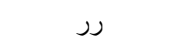 & رد - ت ار & 457 \\
\hline | شانز ده ستفل سه ماه حبس & $1395 / 5 / 25$ & 1 & ل لت وكوب & 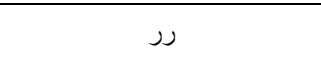 & 458 \\
\hline جهارماه حبس تتفيذى & رد - ت ار & 1 & 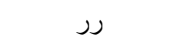 & رد - ت إ & 459 \\
\hline ششماه حبس تنفيذى & رر & 1 & رد & رد & 460 \\
\hline جريمه نقدى & $1395 / 5 / 18$ & 1 & 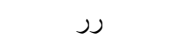 & رد - ت ار & 461 \\
\hline دوماه حبس تتفيذى & 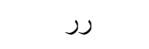 & 1 & رد & رد - ت ار & 462 \\
\hline سه ماه حبس تنفيذى & 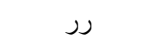 & 1 & رנ & رد - ت إ & 463 \\
\hline جريمه نقدى & $1395 / 5 / 16$ & 1 & 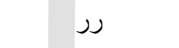 & 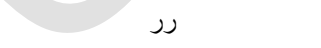 & 464 \\
\hline ششماه حبس تنفيذى & $1395 / 5 / 11$ & 1 & رر & $y$ & 465 \\
\hline دوماه حبس تتفيذى & $1395 / 4 / 29$ & 1 & رد - ت ار & 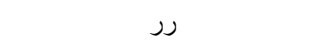 & 466 \\
\hline سه ماه حبس تنفيذى & $1395 / 10 / 27$ & 1 & رد - ت ار & رد & 467 \\
\hline جريمه نقدى & $1395 / 10 / 20$ & 2 & 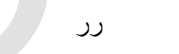 & رد - ت إ & 468 \\
\hline هرو احد يكماه حبس تتفيذى & رנ & 2 & رد & رد & 469 \\
\hline جريمه نقدى & ر & 2 & رر & رر & 470 \\
\hline ينج ماه حبس تنفيذى & $1395 / 12 / 29$ & 2 & 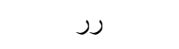 & 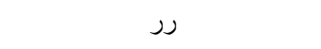 & 471 \\
\hline سه ماه حبس تنفيذى & رر & 1 & 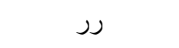 & 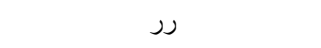 & 472 \\
\hline هرو احد بنفيذّى يكى ماه حبس & رנ & 5 & رر & رر & 473 \\
\hline دوماه حبس تتفيذى & $1395 / 12 / 30$ & 1 & 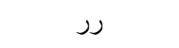 & 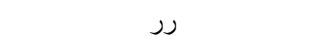 & 474 \\
\hline ششماه حبس تنفيذى & $1395 / 4 / 28$ & 1 & خشونت عليه زن & ديوان جزاى استيناف و لايت ز ابل & 475 \\
\hline يكنفرشانز ده سال دومى & $1395 / 2 / 25$ & 2 & رد & נر & 476 \\
\hline سه ماه حجزتنفيذى & $1395 / 3 / 29$ & 1 & 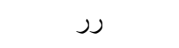 & 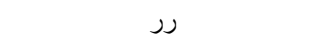 & 477 \\
\hline
\end{tabular}

\section{2}




\section{قـضئ}

\begin{tabular}{|c|c|c|c|c|c|}
\hline ينج سال حجز تنفيذى & $1395 / 1 / 31$ & 1 & 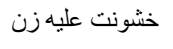 & ديوان جزاى شهرى ولايت زابل & 478 \\
\hline 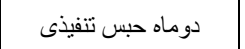 & $1395 / 1 / 15$ & 1 & ل لت وكوب & ديوان جزاى استيناف و لايت لوكر & 479 \\
\hline هشت روزحبس تتفيذى & $1395 / 8 / 17$ & 1 & خشونت عليه زن & 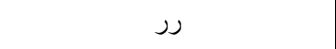 & 480 \\
\hline 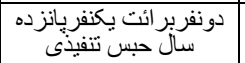 & $1395 / 3 / 23$ & 3 & ر رمنجربه قتل & رנ & 481 \\
\hline يكسال حبس تنفيذى & $1395 / 3 / 8$ & 1 & 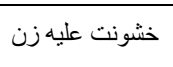 & ديوان جز اي محدهمه استيناف و لايت & 482 \\
\hline يكسال حبس تنفيذى & $1395 / 3 / 8$ & 1 & 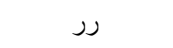 & 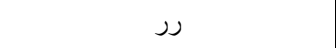 & 483 \\
\hline ششماه حبس تنفيذى & $1395 / 5 / 2$ & 1 & נر & נر & 484 \\
\hline شش سال حبس تنفيذى & $1395 / 2 / 11$ & 2 & 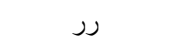 & ديوان جز اى محكمه شهرى كندهار & 485 \\
\hline 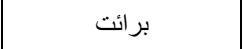 & $1395 / 2 / 25$ & 1 & 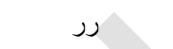 & 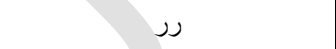 & 486 \\
\hline 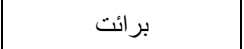 & $1395 / 7 / 10$ & 3 & 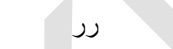 & 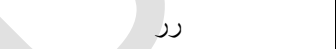 & 487 \\
\hline شش سال حبس تنفيذى & $1395 / 8 / 3$ & 1 & 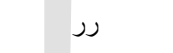 & 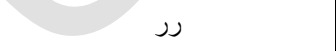 & 488 \\
\hline دوسال حبس تتفيذى & $1395 / 2 / 9$ & 1 & رנ & محكمه ابتدائيه ولسو الى نند كندهار & 489 \\
\hline شش سال حبس تنفيذى & $1395 / 10 / 7$ & 1 & 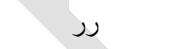 & 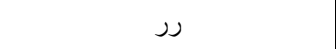 & 490 \\
\hline يكماه حبس تتفيذى & $1395 / 12 / 23$ & 1 & נر & 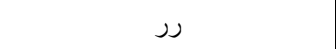 & 491 \\
\hline هرو احد بتيستى سال حبس & $1395 / 12 / 11$ & 2 & منجربقتل & محكمه ابتدائيه شييرو لايت باميان & 492 \\
\hline سه ماه حبس تتفيذى & $1395 / 3 / 11$ & 1 & ضرب جهر & محكمه ابتدائيه سيغان رر & 493 \\
\hline هرو احد جريمه نقدى & $1395 / 5 / 21$ & 2 & 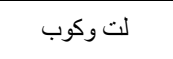 & محكمه ابتدائيه يكه ولنى رر & 494 \\
\hline | ابام سبرى شده كافى است & $1395 / 5 / 20$ & 1 & נر & 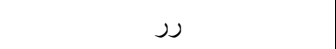 & 495 \\
\hline هرو احد دوماه حبس تتفيذى & $1395 / 12 / 11$ & 2 & 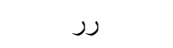 & נر & 496 \\
\hline جريمه نقدى & $1395 / 1 / 29$ & 2 & خشونت وسرقت & ديوان جزاى محكمه استيناف ولايت & 497 \\
\hline يكماه يانز ده روز حبس & $1395 / 4 / 9$ & 1 & 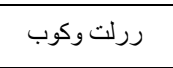 & رנ & 498 \\
\hline دوسال حبس ثتفيذى & $1395 / 5 / 10$ & 1 & נر & נر & 499 \\
\hline يكى سه ماه ويذكى يكماه & $1395 / 6 / 30$ & 2 & رנ & رנ & 500 \\
\hline بر ائت & $1395 / 7 / 11$ & 1 & رر & رر & 501 \\
\hline
\end{tabular}




\section{قـضئ}

\begin{tabular}{|c|c|c|c|c|c|}
\hline جريمه نقدى & $1395 / 7 / 14$ & 2 & رد - ت ار & رد - ت ار & 502 \\
\hline جريمه سقدى ماه حبس دومى بـى & $1395 / 7 / 18$ & 3 & 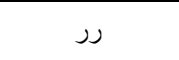 & 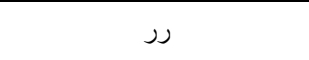 & 503 \\
\hline بنج ماه حبس تنفيذى & $1395 / 8 / 3$ & 1 & 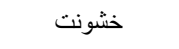 & 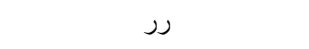 & 504 \\
\hline جريمه نقدى & $1395 / 8 / 8$ & 1 & 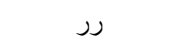 & رد - ت ار & 505 \\
\hline سه ماه حجزتتفيذى & $1395 / 10 / 7$ & 1 & 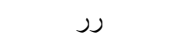 & נر - ت ا & 506 \\
\hline حبس كذشته كافى است & $1395 / 10 / 11$ & 1 & تهديد & رد - ت إ & 507 \\
\hline جريمه نقدى & $1395 / 10 / 4$ & 1 & خشونت & رد & 508 \\
\hline هفت سال حبس تتفيذى & $1395 / 11 / 13$ & 1 & رر & رد & 509 \\
\hline سه ماه حبس تتفيذى & $1395 / 11 / 24$ & 1 & 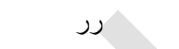 & رد - ت ار & 510 \\
\hline دوماه حبس تتفيذى & $1395 / 11 / 30$ & 1 & رر & رد - ت إ & 511 \\
\hline سه ماه حبس تنفيذى & $1395 / 5 / 27$ & 1 & رر & 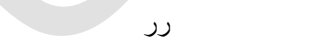 & 512 \\
\hline جريمه نقدى & $1395 / 7 / 13$ & 1 & تهنيد & رد - ت ار & 513 \\
\hline هرواحد جريمه نقدى & $1395 / 3 / 31$ & 2 & خشونت لت وكوب & נر - ت ا & 514 \\
\hline سه ماه حبس تنفيذى & $1395 / 12 / 4$ & 1 & 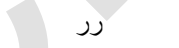 & رد & 515 \\
\hline جريمه نقدى & $1395 / 6 / 10$ & 1 & 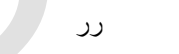 & رد & 516 \\
\hline يكماه حبس تتفيذى & $1395 / 3 / 2$ & 1 & خشونت & ديوان جزاى محكمه شهرى تخار & 517 \\
\hline 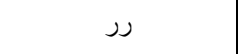 & $1395 / 3 / 9$ & 1 & رر & رد & 518 \\
\hline هرواحد بر ائت & $1395 / 3 / 10$ & 2 & رد - ت ار & 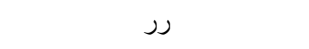 & 519 \\
\hline دونفربه حبس كُنشته & $1395 / 5 / 26$ & 4 & رנ & رر & 520 \\
\hline 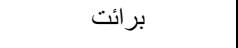 & $1395 / 9 / 14$ & 1 & رد & رנ & 521 \\
\hline سه ماه حبس تنفيذى & $1395 / 10 / 12$ & 1 & 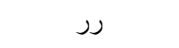 & 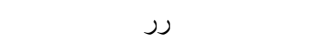 & 522 \\
\hline سله سال وسيه ماه حبس & $1395 / 3 / 27$ & 1 & رנ & נر & 523 \\
\hline دوماه حبس تنفيذى & $1395 / 6 / 15$ & 1 & 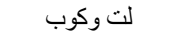 & رנ & 524 \\
\hline 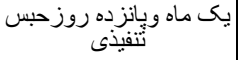 & $1395 / 8 / 29$ & 1 & 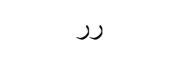 & נر & 525 \\
\hline
\end{tabular}




\section{قـضئ}

\begin{tabular}{|c|c|c|c|c|c|}
\hline هرو احد جريمه نقدى & $1395 / 10 / 22$ & 2 & رد & 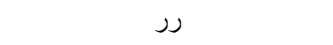 & 526 \\
\hline سه ماه حبس تنفيذى & $1395 / 1 / 14$ & 1 & خشونت & ديوان جزاى محكياب استيناف و لايت & 527 \\
\hline سه ماه حبس تتفيذى & $1395 / 2 / 21$ & 1 & رد - ت ار & 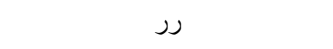 & 528 \\
\hline سه ماه حبس تنفيذى & $1395 / 3 / 23$ & 1 & رد & رد & 529 \\
\hline 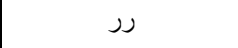 & $1395 / 4 / 22$ & 1 & رנ & נر & 530 \\
\hline برائت & 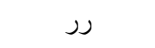 & 1 & رد & رد & 531 \\
\hline يكسال حبس تتفيذى & $1395 / 4 / 29$ & 1 & رנ & رנ & 532 \\
\hline بيست يوم حبس تنفيذى & $1395 / 5 / 2$ & 1 & 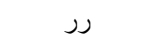 & رد & 533 \\
\hline رد & رد - ت ا & 1 & رد & رנ & 534 \\
\hline جريمه نقدى & $1395 / 5 / 5$ & 1 & رנ & 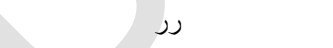 & 535 \\
\hline سه ماه حبس تتفيذى & $1395 / 5 / 23$ & 1 & 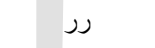 & 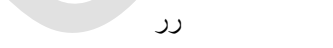 & 536 \\
\hline بنج سال ويكماه حبس & $1395 / 5 / 31$ & 1 & رנ & 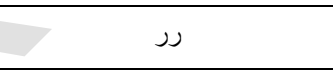 & 537 \\
\hline برائت & $1395 / 6 / 30$ & 1 & رנ & נر & 538 \\
\hline 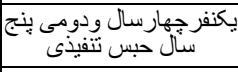 & $1395 / 6 / 7$ & 2 & رد & رر & 539 \\
\hline برائت & $1395 / 7 / 17$ & 1 & 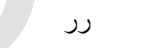 & رد & 540 \\
\hline يكماه حبس تتفيذى & $1395 / 8 / 1$ & 1 & رر & رر & 541 \\
\hline 4يوم حبس & $1395 / 9 / 24$ & 1 & رر & رر & 542 \\
\hline سه ماه حبس تتفيذى & $1395 / 9 / 13$ & 1 & رر & رנ & 543 \\
\hline برائت & $1395 / 9 / 1$ & 2 & 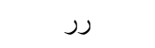 & رد & 544 \\
\hline دوازده روزحبس تنفيذى | & $1395 / 10 / 28$ & 1 & رנ & 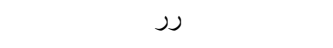 & 545 \\
\hline ينج ماه حبس تتفيذى & $1395 / 11 / 24$ & 1 & 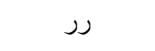 & 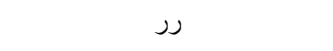 & 546 \\
\hline سه ماه حبس تنفيذى & $1395 / 11 / 27$ & 1 & נر & 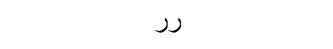 & 547 \\
\hline سه ماه حبس تنفيذى & $1395 / 2 / 14$ & 1 & ضرب وجرح & ديو ان جزاى محكمه استيناف ولايت & 548 \\
\hline ششماه حبس تتفيذى & 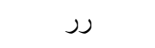 & 1 & 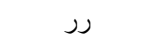 & رد - ت ار & 549 \\
\hline
\end{tabular}




\section{قـضئ}

\begin{tabular}{|c|c|c|c|c|c|}
\hline هرو احد جريمه نقدى & $1395 / 2 / 24$ & 2 & 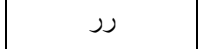 & 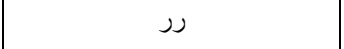 & 550 \\
\hline نوسال حبس تنفيذى & $1395 / 5 / 17$ & 1 & خشونت منجربه فوت & رد & 551 \\
\hline جهارماه حبس تتفيذى & $1395 / 3 / 25$ & 1 & ضرب وجرح & رد & 552 \\
\hline هرو احد جريمه نقدى & $1395 / 6 / 15$ & 2 & 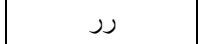 & رد & 553 \\
\hline شانزده سال حبس تتفيذى & $1395 / 7 / 26$ & 1 & قتل زن & נر & 554 \\
\hline جريمه نقدى & $1395 / 8 / 2$ & 1 & ضرب وجرح & رد & 555 \\
\hline يكماه حبس تنفيذى & $1395 / 8 / 24$ & 1 & 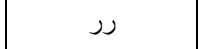 & 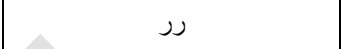 & 556 \\
\hline هجده سال حبس تتفيذى & $1395 / 9 / 15$ & 1 & قتل زن & 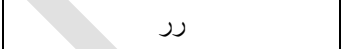 & 557 \\
\hline سه ماه حبس تتفيذى & $1395 / 9 / 29$ & 1 & ضرب وجرح & رر & 558 \\
\hline يكسال حبس تنفيذى & $1395 / 4 / 16$ & 1 & خشونت عليه زن & 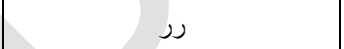 & 559 \\
\hline ينج سال حبس تنفيذى & $1395 / 8 / 25$ & 1 & נر & 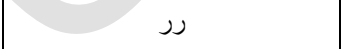 & 560 \\
\hline هجده سال حبس تتفيذى & $1395 / 7 / 26$ & 1 & قتل زن & لحر & 561 \\
\hline يكسال حبس تنفيذى & $1395 / 4 / 6$ & 1 & خشونت عليه زن & محكمه ابتدائيه ولسو الى جاغور غزنى & 562 \\
\hline ينج سال حبس تنفيذى & $1395 / 8 / 25$ & 1 & 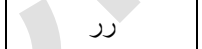 & 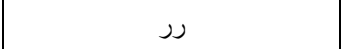 & 563 \\
\hline هجده سال حبس تتفيذى & $1395 / 7 / 26$ & 1 & 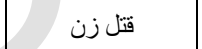 & ل ار & 564 \\
\hline سه ماه حبس تنفيذى & $1395 / 2 / 14$ & 1 & 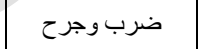 & ديوان جزاى استيناف غزنى & 565 \\
\hline ششماه حبس تنفيذى & 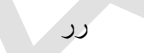 & 1 & נر - ت إ & נر & 566 \\
\hline جهار ماه حبس تتفيذى & נر & 1 & 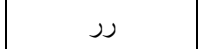 & ل در & 567 \\
\hline هرو احد جريمه نقدى & $1395 / 6 / 15$ & 2 & 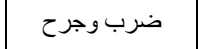 & 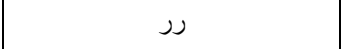 & 568 \\
\hline شانزده سال حبس تنفيذى & $1395 / 7 / 26$ & 1 & 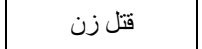 & 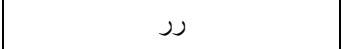 & 569 \\
\hline جريمه نقدى & $1395 / 8 / 2$ & 1 & 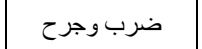 & 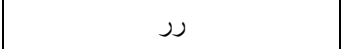 & 570 \\
\hline يكماه حبس تتفيذى & $1395 / 8 / 24$ & 1 & 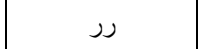 & 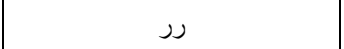 & 571 \\
\hline هجده سال حبس تتفيذى & $1395 / 9 / 15$ & 1 & 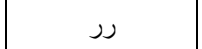 & ل در & 572 \\
\hline سه ماه حبس تنفيذى & $1395 / 9 / 29$ & 1 & رر & رد & 573 \\
\hline
\end{tabular}




\section{قـضئ}

\begin{tabular}{|c|c|c|c|c|c|}
\hline هرو احد جريمه نقدى & $1395 / 2 / 24$ & 2 & رנر & رנ & 574 \\
\hline دوماه حبس تتفيذى & $1395 / 6 / 13$ & 1 & خشونت عليه زن & ديوان جز اى محكمه استيناف و لايت & 575 \\
\hline جهار ماه حبس تنفيذى & $1395 / 6 / 7$ & 1 & 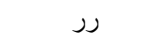 & 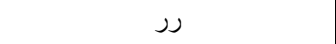 & 576 \\
\hline ده يوم حبس تتفيذى & $1395 / 6 / 12$ & 1 & رد & 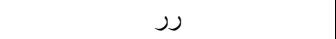 & 577 \\
\hline يكماه حبس تتفيذى & $1395 / 7 / 7$ & 1 & 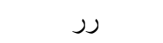 & 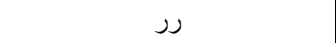 & 578 \\
\hline بر علاوه توقيف جريمه & 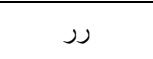 & 1 & נر & נر & 579 \\
\hline حبس كذشته كافى & $1395 / 10 / 6$ & 1 & נر & נر & 580 \\
\hline برى الذمه & $1395 / 10 / 28$ & 1 & 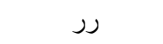 & 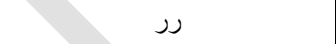 & 581 \\
\hline يكسال وشيذى تشماه حبس & $1395 / 11 / 23$ & 1 & 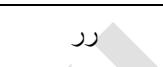 & נر & 582 \\
\hline دوسال حبس تنفيذى & $1395 / 6 / 2$ & 1 & 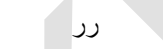 & 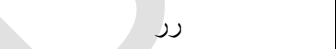 & 583 \\
\hline حبس كذشته كافى & $1395 / 6 / 16$ & 1 & נر & 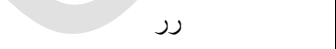 & 584 \\
\hline يكماه وينجنج روزحبس & נر & 1 & لت وكوب & ديوان رسيد كَى به تخلفات اطفال & 585 \\
\hline دوسال حبس تتفيذى & $1395 / 2 / 14$ & 1 & آزارواذيت & ديوان جزاى محكمه ابتدائيه شهرى بلخ & 586 \\
\hline دوماه حبس تتفيذى & $1395 / 2 / 28$ & 1 & لت وكوب & رנ & 587 \\
\hline سه ماه حبس تنفيذى & $1395 / 2 / 21$ & 1 & آز ارو اذيت & 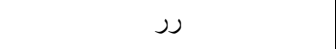 & 588 \\
\hline سه ماه حبس تنفيذى & $1395 / 3 / 4$ & 1 & تهديد به مرگ & 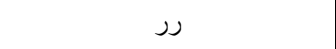 & 589 \\
\hline سه سال حبس تنفيذى & $1395 / 3 / 11$ & 1 & قتل & 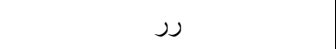 & 590 \\
\hline بيست سال حبس تتفيذى & $1395 / 3 / 25$ & 1 & قتل & נر - ت ا & 591 \\
\hline هرواحد دو دو ماه حبس & $1395 / 3 / 2$ & 2 & لت وكوب & 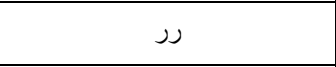 & 592 \\
\hline يكماه حبس تنفيذى & $1395 / 5 / 6$ & 1 & رد - لَ & رد - لَ & 593 \\
\hline يكى سه ماه حبس ودومى الذمه & $1395 / 3 / 16$ & 2 & נر - ت ا & נر & 594 \\
\hline برى الذمه & $1395 / 3 / 25$ & 2 & خشونت & 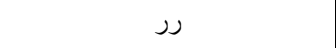 & 595 \\
\hline سه ماه حبس تتفيذى & $1395 / 4 / 10$ & 1 & لت وكوب & 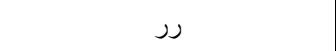 & 596 \\
\hline جهاه ماه حبس تتفيذى & $1395 / 4 / 7$ & 1 & آز ارو اذيت & رנر & 597 \\
\hline
\end{tabular}

\section{7}




\section{قـضئ}

\begin{tabular}{|c|c|c|c|c|c|}
\hline يكماه حبس تتفيذى & $1395 / 4 / 30$ & 1 & لت وكوب & 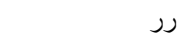 & 598 \\
\hline سه ماه حبس تنفيذى & $1395 / 4 / 26$ & 1 & 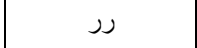 & 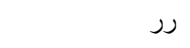 & 599 \\
\hline ده يوم حبس تتفيذى & $1395 / 5 / 2$ & 1 & رد - ت ار & 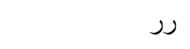 & 600 \\
\hline برى الذهـ & $1395 / 5 / 26$ & 1 & دشنام وتخويف & 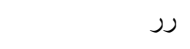 & 601 \\
\hline | بانزده روزحبس تتفيذى & $1395 / 6 / 1$ & 1 & لت وكوب & 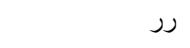 & 602 \\
\hline ينج ماه حبس تنفيذى & $1395 / 6 / 10$ & 1 & آزار و اذيت & رد - ت ار & 603 \\
\hline برى الذهـ & $1395 / 5 / 18$ & 1 & لت وكوب & 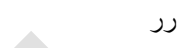 & 604 \\
\hline ششماه حبس تتفيذى & $1395 / 7 / 19$ & 1 & مجروحيت & 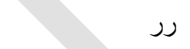 & 605 \\
\hline شانز ده سال حبس تتفيذى & 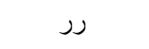 & 1 & 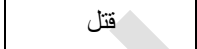 & رد - ت ار & 606 \\
\hline برى الذمه & $1395 / 8 / 3$ & 1 & تهديد & 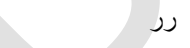 & 607 \\
\hline برى الذهه & $1395 / 8 / 3$ & 1 & حلق اويز & 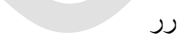 & 608 \\
\hline هرو احد برى الذمه & $1395 / 8 / 12$ & 3 & لت كوب ودشنام & رد - ت ار & 609 \\
\hline برى الذها & $1395 / 8 / 26$ & 1 & لت وكوب & رد - ت ار & 610 \\
\hline جهارماه حبس تتفيذى & $1395 / 8 / 26$ & 1 & مجروحيت & 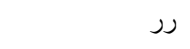 & 611 \\
\hline حبس كنشته كافى & $1395 / 9 / 8$ & 1 & رد - ت ار & 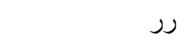 & 612 \\
\hline برى الذها & ر & 2 & قتل & رد - ت ار & 613 \\
\hline ينج سال حبس تنفيذى & $1395 / 9 / 25$ & 1 & ازقدام به قتل وظيفتفادي & رر & 614 \\
\hline بازده روزحبس تتفيذى & $1395 / 11 / 1$ & 1 & لت ل ل وكوب & 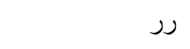 & 615 \\
\hline |هرواحد يازدئى روز حبس & رנر & 2 & لت وكوِّ موشوردن & נر & 616 \\
\hline حبس كنشه كافى است & $1395 / 11 / 2$ & 1 & ل لت وكوب & 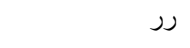 & 617 \\
\hline برى الذهـ & رد - ت ار & 1 & ازارو اذيت & رد - ت ار & 618 \\
\hline اعدام و جريمه نقدى & 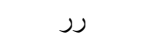 & 1 & | مجروحيت منجربقتل | & 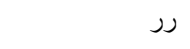 & 619 \\
\hline جهار ماه حبس تنفيذى & رנ & 1 & دوودشنام & 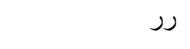 & 620 \\
\hline يكى ونيم ماه حجزتنفيذى & $1395 / 5 / 25$ & 1 & لت وكوب & 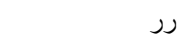 & 621 \\
\hline
\end{tabular}

\section{8}




\section{قـضئ}

\begin{tabular}{|c|c|c|c|c|c|}
\hline 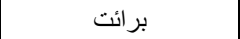 & $1395 / 7 / 20$ & 1 & رנر & رر & 622 \\
\hline حبس كذشته كافى & $1395 / 1 / 5$ & 1 & خشونت & ديوان محكمه ابتدائيه مارمل بلخ & 623 \\
\hline برى الذمه & $1395 / 8 / 8$ & 1 & رر & رد & 624 \\
\hline ينج ماه حبس تنفيذى & $1395 / 7 / 19$ & 1 & آزار و اذيت & محكمه ابتدائيه بلخ & 625 \\
\hline جهار ماه حبس تتفيذى & $1395 / 3 / 20$ & 1 & 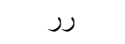 & 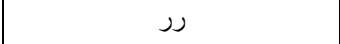 & 626 \\
\hline يانزده سال حبس وجريمه & $1395 / 2 / 22$ & 1 & لت وكوب & محكمه ابتدائيه خلم بلخ & 627 \\
\hline يانز ده يوم حبس & رנ & 1 & נر & נر & 628 \\
\hline سه ماه حبس تعلقى & $1395 / 6 / 13$ & 1 & 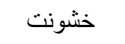 & محكمه ابتدائيه ولسو الى نهرشاهى بلخ & 629 \\
\hline جريمه نقدى & $1395 / 3 / 2$ & 1 & ل لتوكوب & ديو ان جزاى محخشهان استيناف و لايت & 630 \\
\hline نقدى ويكنفريكماه حبس تنفيذى & $1395 / 12 / 29$ & 3 & נر & رد & 631 \\
\hline جريمه نقدى & $1395 / 8 / 15$ & 2 & 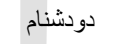 & رر & 632 \\
\hline سه ماه حبس تنفيذى & $1395 / 11 / 6$ & 1 & لت وكوب & 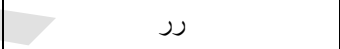 & 633 \\
\hline يكسال وششماه حبس & $1395 / 5 / 30$ & 1 & ر & | محكمده ابتدائيه ولسو الى كثم بدخشان | & 634 \\
\hline يكسال حبس تنفيذى & $1395 / 1 / 23$ & 1 & رر & 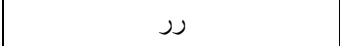 & 635 \\
\hline شش ماه حبس تنفيذى & $1395 / 3 / 25$ & 1 & 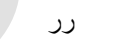 & נر & 636 \\
\hline دوماه حبس تتفيذى & $1395 / 12 / 1$ & 1 & 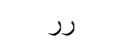 & 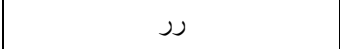 & 637 \\
\hline جريمه نقدى & $1395 / 4 / 26$ & 1 & رد - تار & رر - تا & 638 \\
\hline جريمه نقدى & $1395 / 5 / 24$ & 1 & 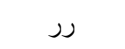 & 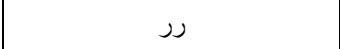 & 639 \\
\hline هرو احد جريمه نقدى & $1395 / 5 / 11$ & 2 & 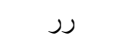 & 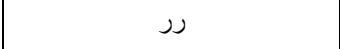 & 640 \\
\hline جريمه نقدى & $1395 / 12 / 8$ & 2 & 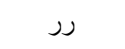 & 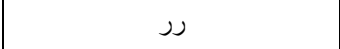 & 641 \\
\hline يكماه حبس تتفيذى & $1395 / 10 / 5$ & 2 & 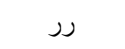 & محكمه ابتدائيه جرم بدخشان & 642 \\
\hline يكى نفريكماه حبس تتفيذى | & $1395 / 12 / 1$ & 3 & 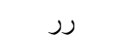 & محكمه ابتدائيه در ايم بدخشان & 643 \\
\hline يكماه حبس تنفيذى & $1395 / 10 / 18$ & 1 & 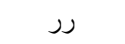 & محكمه ابتدائيه شهداء بدخشان & 644 \\
\hline جريمه نقدى & $1395 / 1 / 8$ & 2 & رر & محكمه ابتدائيه شغنان بدخشان & 645 \\
\hline
\end{tabular}




\section{قـضئ}

\begin{tabular}{|c|c|c|c|c|c|}
\hline جهار ماه حبس تتفيذى & $1395 / 8 / 24$ & 1 & 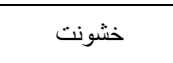 & ديو ان جز اى محكمها استيناف و لايت & 646 \\
\hline سه ماه حبس تنفيذى & 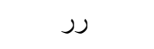 & 1 & 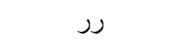 & 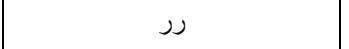 & 647 \\
\hline 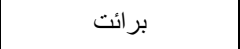 & $1395 / 10 / 27$ & 1 & 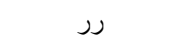 & 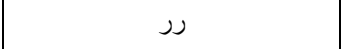 & 648 \\
\hline سه ماه حبس تنفيذى & $1395 / 7 / 26$ & 1 & 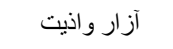 & محكمه شهرى و لايت كاييسا & 649 \\
\hline ششماه حبس تتفيذى & $1395 / 9 / 15$ & 1 & خشونت فاميلى & נر & 650 \\
\hline 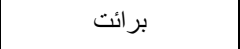 & $1395 / 9 / 13$ & 1 & 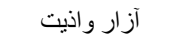 & 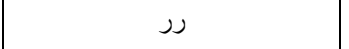 & 651 \\
\hline ده روزحبس تنفيذى & $1395 / 11 / 10$ & 1 & 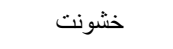 & 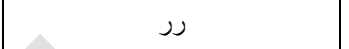 & 652 \\
\hline ده سال حبس تنفيذى & $1395 / 6 / 2$ & 1 & خشونت & ديوان جز اى محكمة استيناف و لايت & 653 \\
\hline هرو احس ياز تنفيذى بازده سال & 1395/11/19 & 2 & رנ & נر & 654 \\
\hline جريمه نقدى & $1395 / 3 / 10$ & 1 & سقط جنين & ديو ان جزاى محكيل استيناف و لايت & 655 \\
\hline 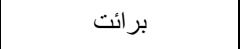 & $1395 / 3 / 31$ & 2 & 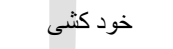 & 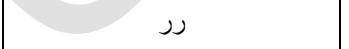 & 656 \\
\hline يكسال و هشت ماه حجز & $1395 / 6 / 10$ & 1 & افثاى اسر ار & ديو ان جزاى محكمه شهرى سريل & 657 \\
\hline هرو احد جريمه نقدى & $1395 / 6 / 17$ & 3 & لت وكوب & محكمه ابتدائيه سانجارى رر & 658 \\
\hline جريمه نقدى & $1395 / 9 / 11$ & 1 & 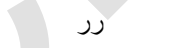 & 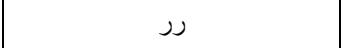 & 659 \\
\hline 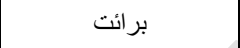 & $1395 / 11 / 2$ & 1 & נر & נر & 660 \\
\hline سه ماه حبس تنفيذى & $1395 / 10 / 13$ & 1 & 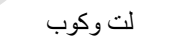 & محكمه ابتدائيه ولسو الى بلخ آب سريل & 661 \\
\hline دوماه دو إزده روزحبس & $1395 / 9 / 22$ & 1 & خشونت & ديو ان محكمه خنج و لايت يُنشير & 662 \\
\hline شش سال حبس تنفيذى & $1395 / 3 / 29$ & 1 & خشونت منجربقتل & ديوان جزاى محكمه استيناف و لايت & 663 \\
\hline ششماه حبس تتفيذى & $1395 / 3 / 31$ & 1 & 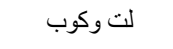 & 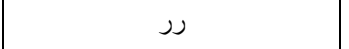 & 664 \\
\hline سه ماه حبس تنفيذى & $1395 / 11 / 30$ & 1 & 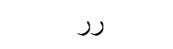 & 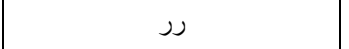 & 665 \\
\hline \multirow[t]{2}{*}{ يكنفرينج ماه حبس يكماه دو ميذى } & ندارد & 2 & خشونت عليه زن & ديو ان جز اى محكمه شهرى و لايت & 666 \\
\hline & & 825 & & & \\
\hline
\end{tabular}

\section{0}


ازفعاليتهاى محاكم در رسيده كى به قضاياى خثونت عليه زن

\section{اجمـالى از فعاليتها}

\section{درراستاى مبارزه با فساد ادارى ومواليتهاد مخدر}

الف: كزارش فعاليتهاي قضائي محكمه ابتدائيهُ مبارزه با جرايم ناشي

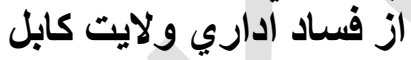

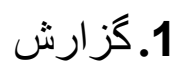

محكمة ابتدائية مبارزه با جر ايم ناثني از فساد اداري ولايت كابل از تاريخ

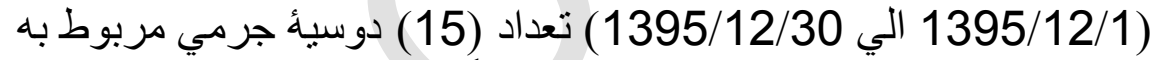

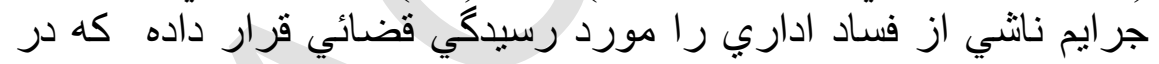

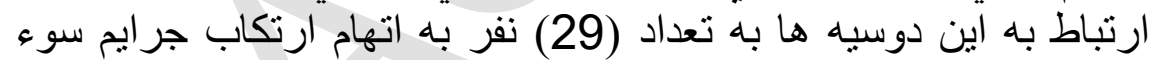

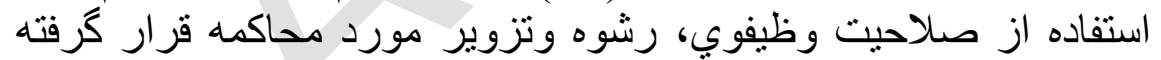

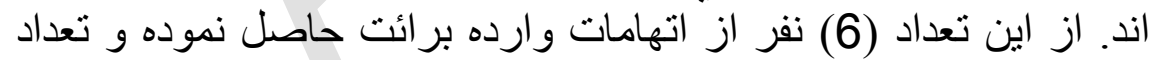

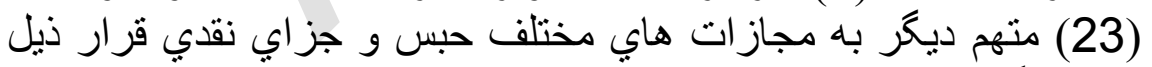
محكوم كرديده اند:

حبس يك ماه الى يك سال 21 نفر.

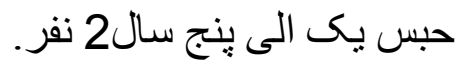

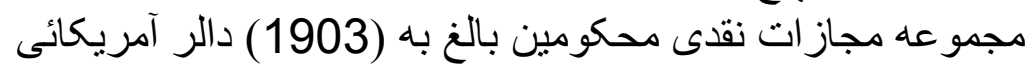
مبشود. 
اجمالى از فعاليتها در راستاى مبارزه با فساد ادارى ومواد مخدر

جدول شماره (1) بيانكر آمار محكومين محكمه ابتدائيه مبارزه با جرايم

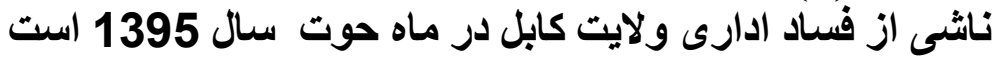

\begin{tabular}{|c|c|c|c|c|c|c|c|c|c|c|c|}
\hline \multicolumn{9}{|c|}{ تصميم قضائى } & \multirow[b]{3}{*}{ 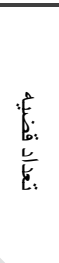 } & \multirow[b]{3}{*}{$\begin{array}{l}\sum_{0}^{*} \\
\tilde{c}\end{array}$} & \multirow[b]{3}{*}{$\check{\xi}$} \\
\hline \multicolumn{6}{|c|}{ تعداد محبوس به حبس تنفيذى } & \multirow[b]{2}{*}{$\begin{array}{l}\xi \\
\xi \\
\xi \\
\xi\end{array}$} & \multirow[b]{2}{*}{$\underline{E}$} & \multirow[b]{2}{*}{$\begin{array}{l}\text { s. } \\
\frac{L}{E}\end{array}$} & & & \\
\hline نقديمه & 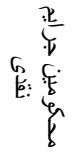 & 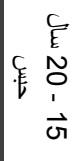 & 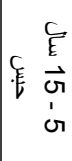 & $\begin{array}{l}\mathcal{E} \\
E \\
c \\
E \\
G \\
1 \\
-\end{array}$ & 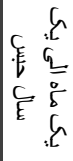 & & & & & & \\
\hline$\$ 1565$ & & & & & 15 & 15 & 6 & 21 & 10 & سو وظعاحيت استفاده & 1 \\
\hline$\$ 338$ & & & & 1 & 3 & 4 & 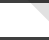 & 4 & 3 & رشوت & \\
\hline & & & & 1 & 3 & 4 & & 4 & 2 & تززوير & $r$ \\
\hline $1903 \$$ & & & & 2 & 21 & 23 & 6 & 29 & 15 & 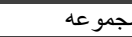 & \\
\hline
\end{tabular}

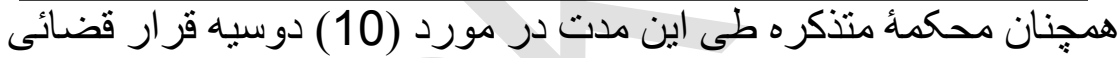

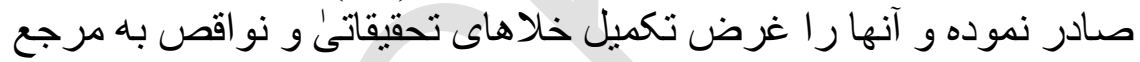
مربوطه ارسال نموده است.

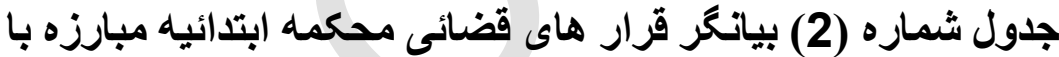

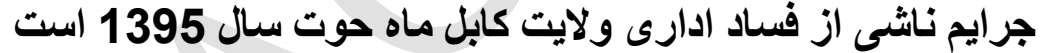

\begin{tabular}{|c|c|c|c|c|c|}
\hline \multirow[b]{2}{*}{ مرجع مربوط } & سبب قرار & \multirow[b]{2}{*}{ تعداد متهم } & \multirow[b]{2}{*}{ تعداد قضيه } & \multirow[b]{2}{*}{ نوع قضيه } & \multirow[b]{2}{*}{ ت نماره } \\
\hline & خلا و نو اقص & & & & \\
\hline خُارنو اللى & 5 & 8 & 5 & صلاحيت و ظتفاده ازى & 1 \\
\hline خارنو الى & 3 & 14 & 3 & تزوير & 2 \\
\hline خارنو الىى & 1 & 16 & 1 & اختلاس & 3 \\
\hline خارنو الىى & 1 & 1 & 1 & باقيدارى سلاح & 4 \\
\hline & 10 & 39 & 10 & لجمو عه & \\
\hline
\end{tabular}

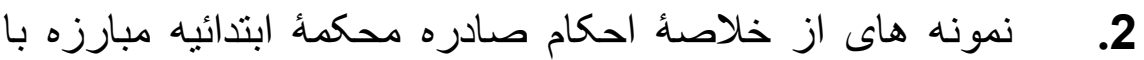
جر ايم ناشى از فساد ادارى و لايت كايت كابل 
اجمالى از فعاليتها در راستاى مبارزه با فساد ادارى ومواد مخدر

\section{قضغناء}

\section{5/12/16 مكم مورخ}

محكوميت يكتن از افسران بيزئنتون وزارت امور داخله به اتهام اخذ رشوث

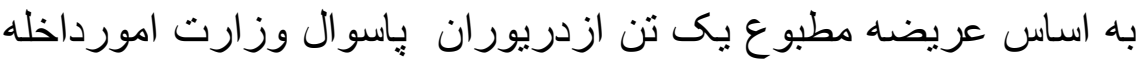

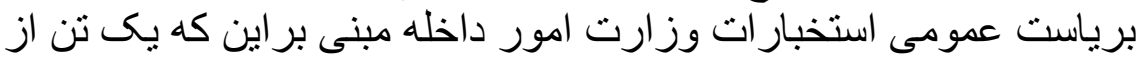

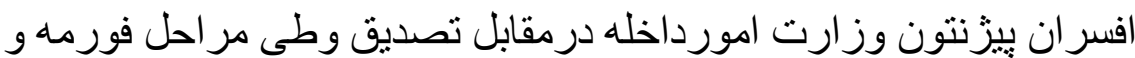

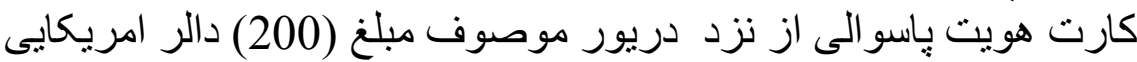

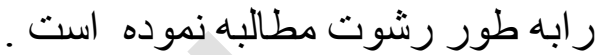

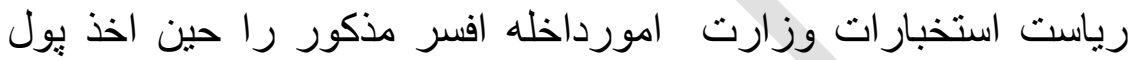

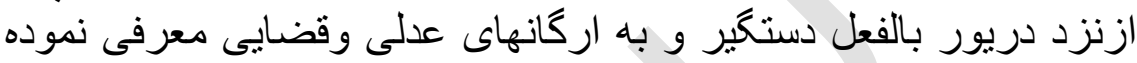
است .

قضيه بعد از تكميل تحقيقات ابتدايى محول محكمه ابتدائيه مبارزه با جر ايم

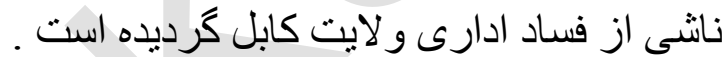

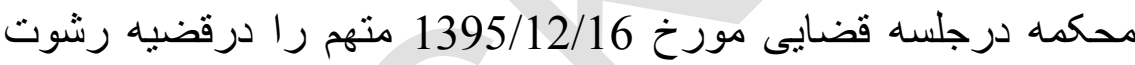

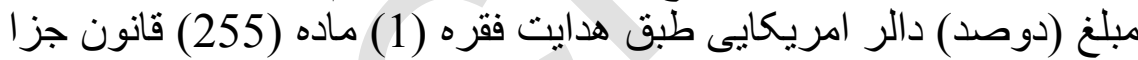

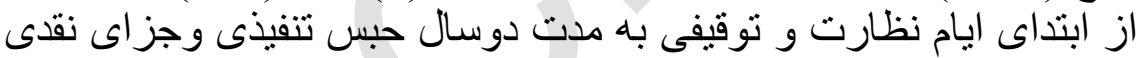

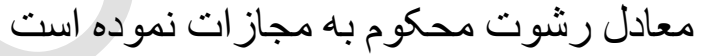

\section{حكم مورخ 1395/12/29} محكوميت يك تن از سرباز ان قومانداندانى امنيه ولايت كابل به اتهام تذوير

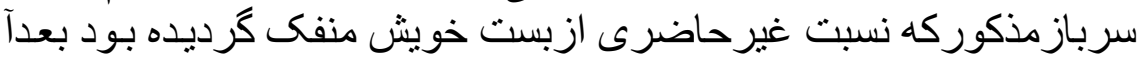

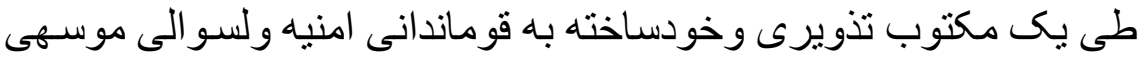

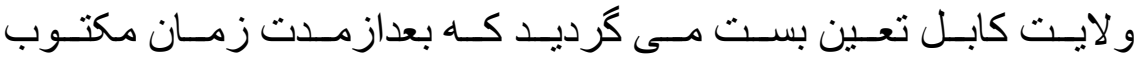

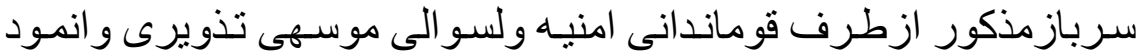

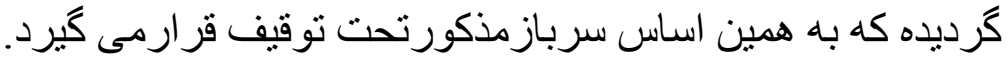


اجمالى از فعاليتها در راستاى مبارزه با فساد ادارى ومواد مخدر

قُخاءو

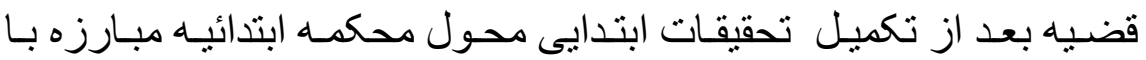

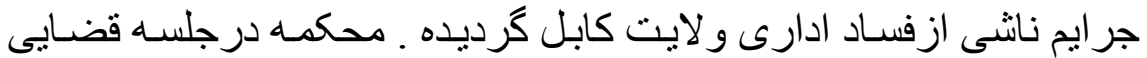

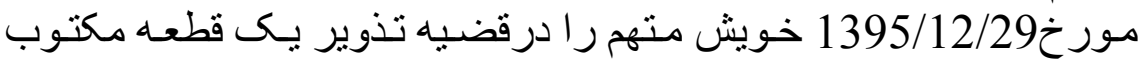

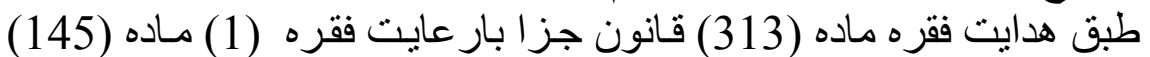

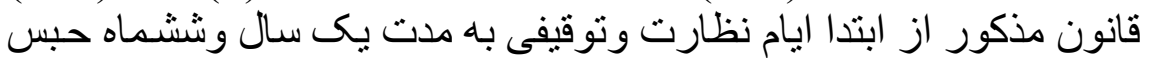

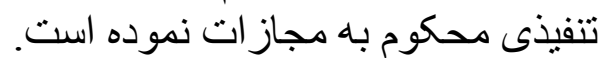

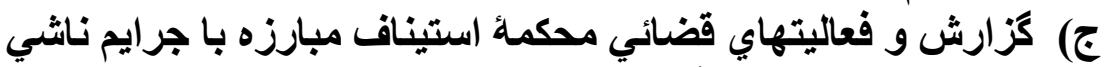

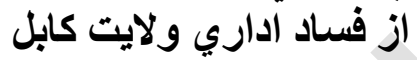

$$
\text { 1 ) مز ارش }
$$

محكمة استيناف مبارزه با جرايم ناشي از فساد اداري و لايت كابل از تاريخ

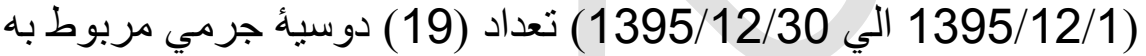

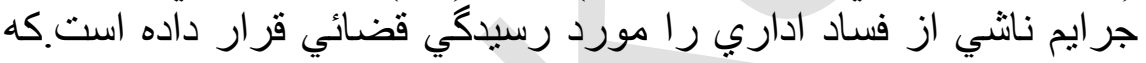

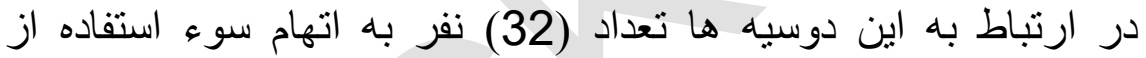

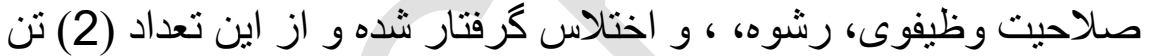

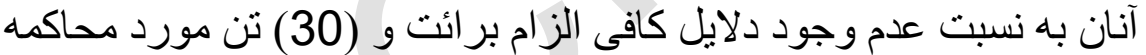
قرار كرفته و به مجاز ات هاي مختلف حبس قر ار ذايل ذيل محكوم كرديده اند.

$$
\text { حبس يك ماه الى يك سال } 14 \text { نفر. }
$$

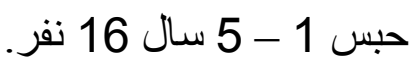

مجمو عه مجازات نقدى محكومين بالغ بـ به (78735) دالر

$$
\text { آمريكائى ميثود. }
$$

جدول شماره (1) بيانكر آمار اجرآت محكمه استيناف مبارزه با جرايم

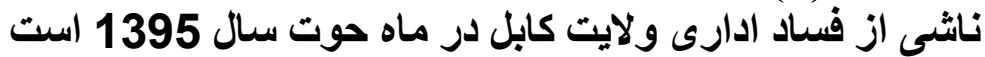

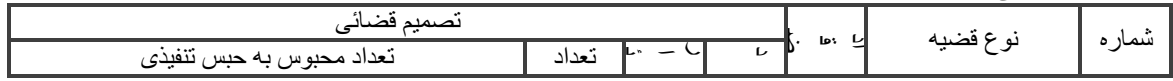




\section{قائر}

\begin{tabular}{|c|c|c|c|c|c|c|c|c|c|c|}
\hline جريمه نقاى & 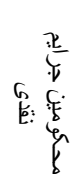 & 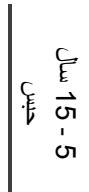 & $\begin{array}{l}E \\
E \\
E \\
E \\
G \\
\vdots \\
-\end{array}$ & 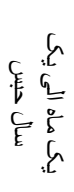 & محكوم & & & & & \\
\hline $10110 \$$ & & & 6 & 13 & 19 & & 19 & 10 & صلاحيت وظفيفوى استفي & 1 \\
\hline$\$ 450$ & & & 2 & & 2 & & $r$ & 2 & اختلاس & $r$ \\
\hline $10000 \$$ & & & 4 & & 4 & & 4 & 3 & اخذ رشوت & $r$ \\
\hline$\$ 7073$ & & & 3 & 1 & 4 & 1 & 5 & 3 & صلاحيت وظيفوى ورى & $r$ \\
\hline$\$ 51102$ & & & 1 & & 1 & 1 & 2 & 1 & صلاحيت وظتفادهفى & 5 \\
\hline $78735 \$$ & & & 16 & 14 & 30 & 2 & 32 & 19 & مجمو عه & \\
\hline
\end{tabular}

همدُنان محكمهُ طى اين مدت در مورد (13) دوسيه قر ار قضائى صادر

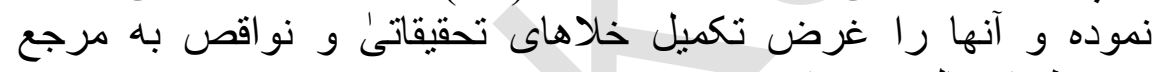
مربوطه ارسال نموده است.

جدول شماره (2) بيانكر قرار هاى قضائى محكمه استيناف مبارزه بـ باد

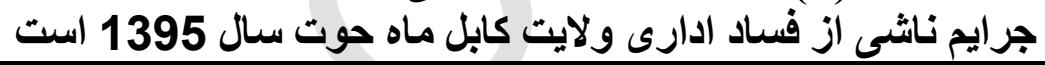

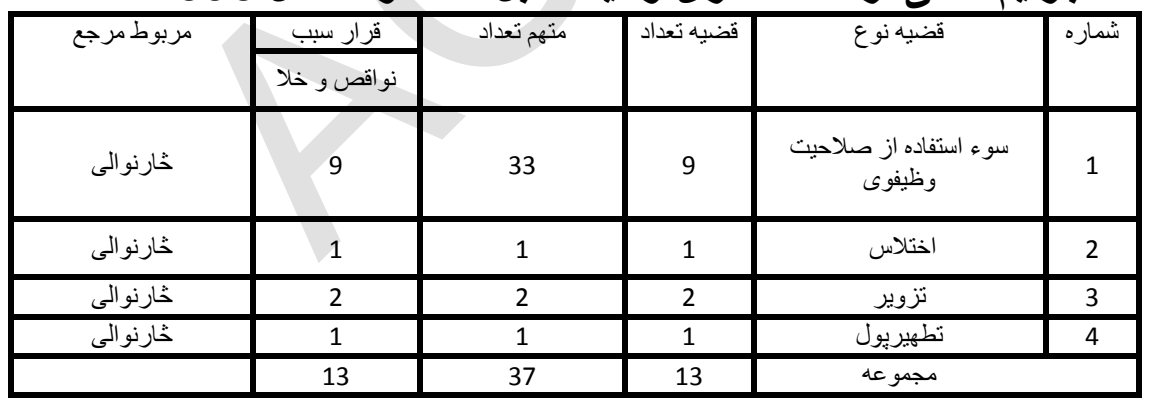

4: خلاصه نمونه هاى از احكام صادره محكمة استيناف مبارزه با

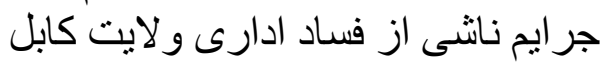

1395/12/9 حكم مورخ 
اجمالى از فعاليتها در راستاى مبارزه با فساد ادارى ومواد مخدر

قُخاءو

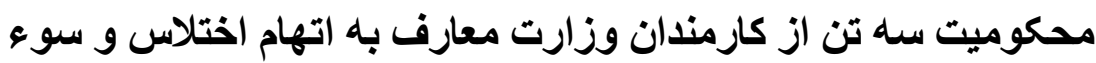
استفاده از صلاحيت وظيفوى وزئ مارف

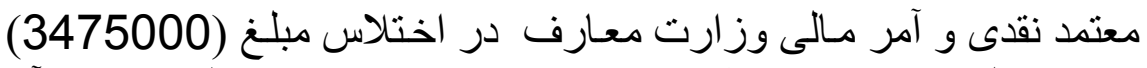

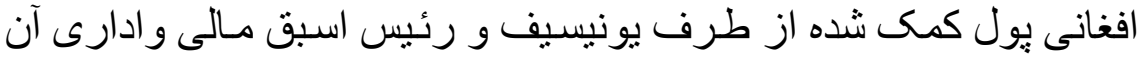

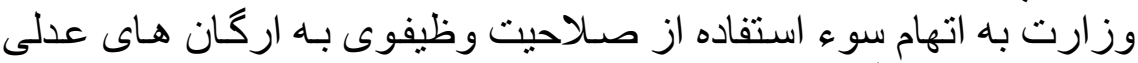
وقضايى معرفى كرديد.

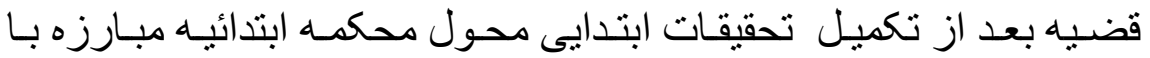

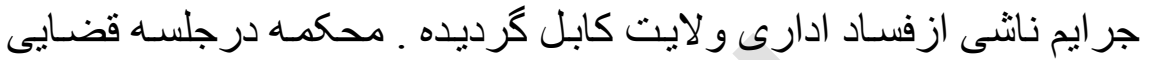

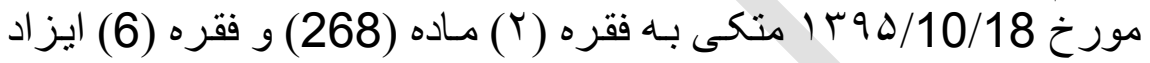

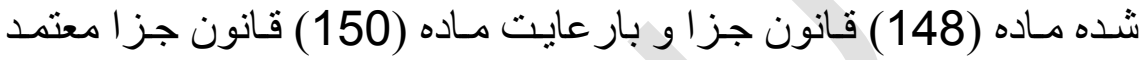

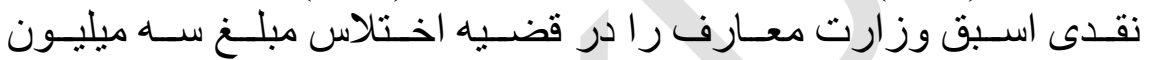

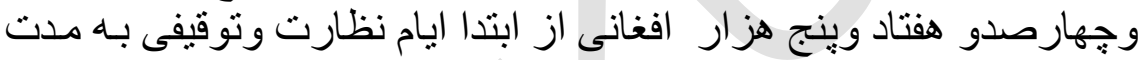

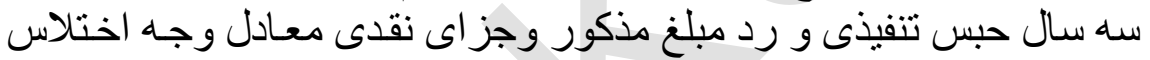

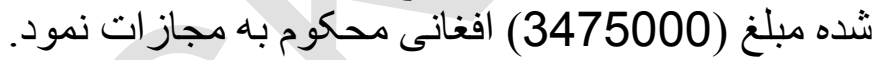

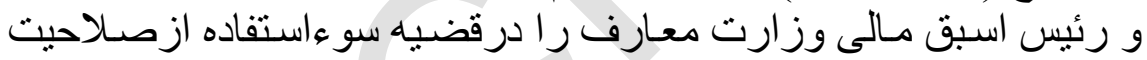

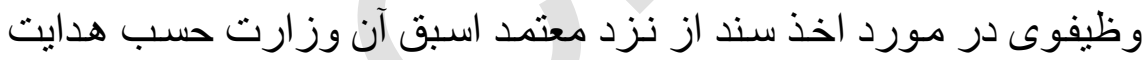

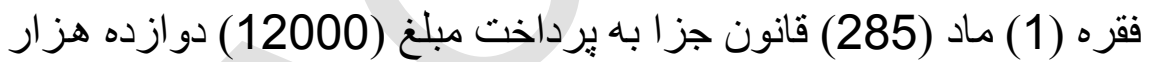

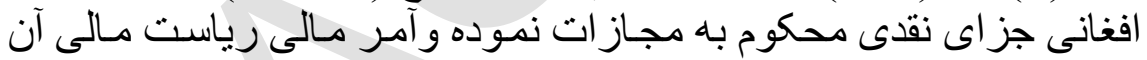

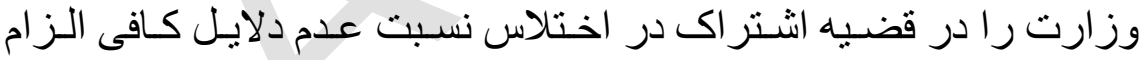

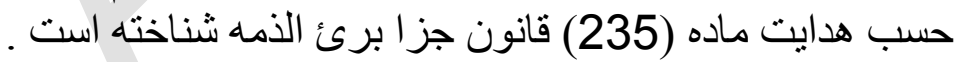

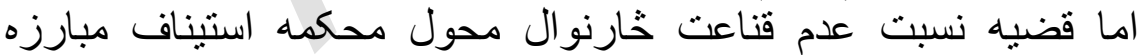

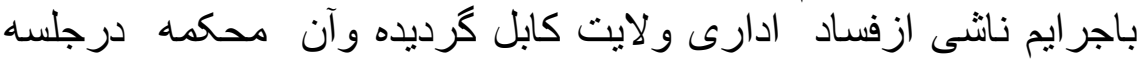

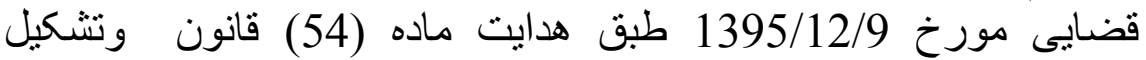

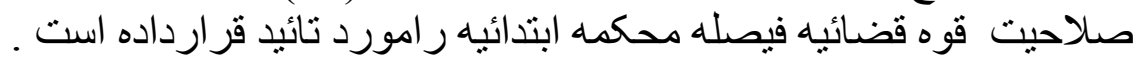

1395/12/14 حكم مورن فئن محكوميت يك تن از انجنيران رياست اسكان وزارت شهرسازى 
اجمالى از فعاليتها در راستاى مبارزه با فساد ادارى ومواد مخدر

قـانو

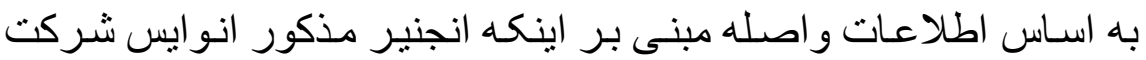

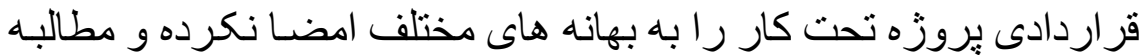

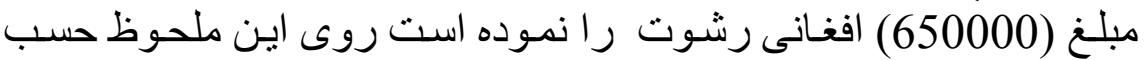

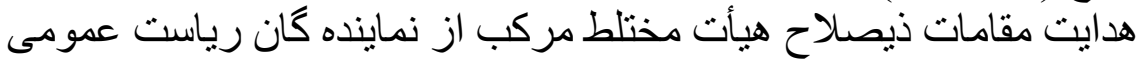

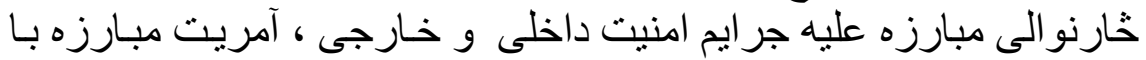

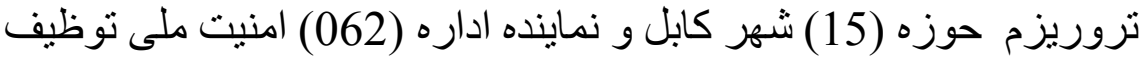

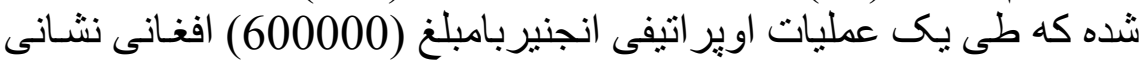

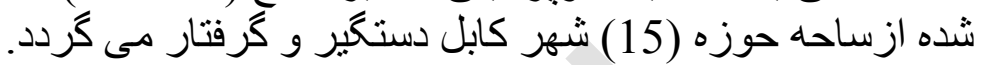

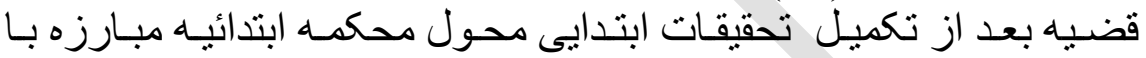

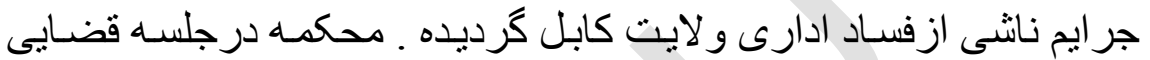

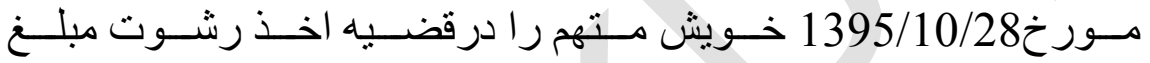

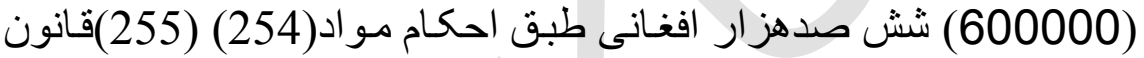

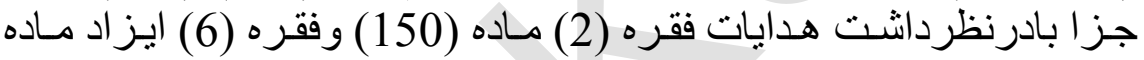

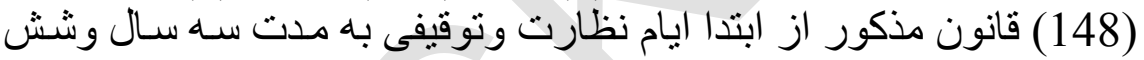

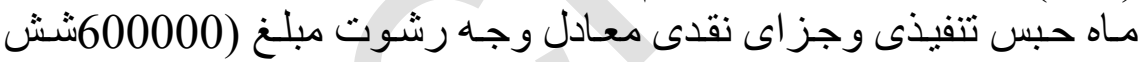

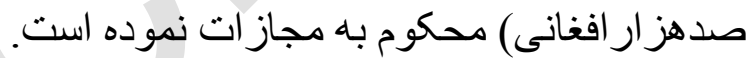

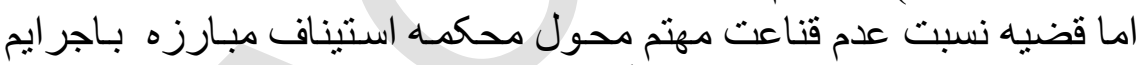

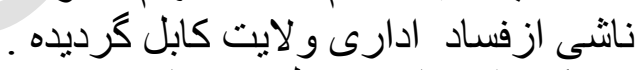

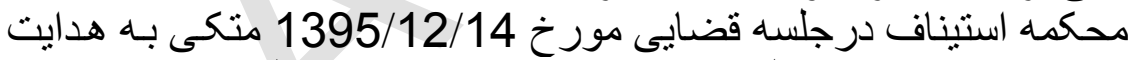

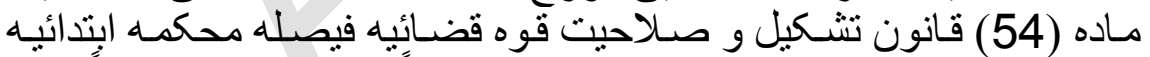

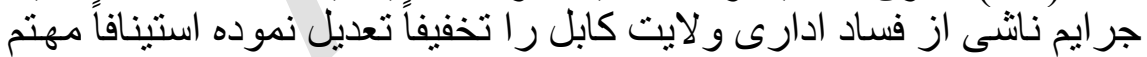

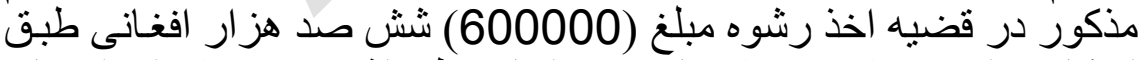

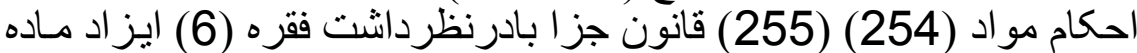

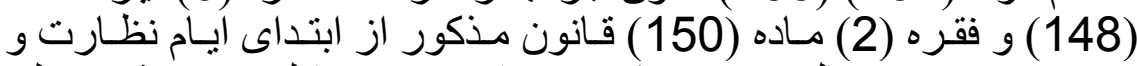

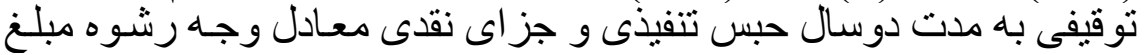

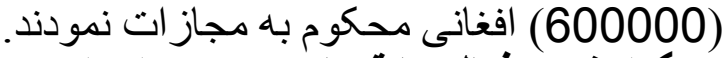

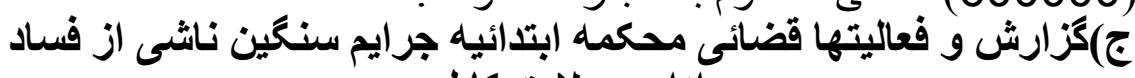

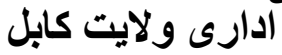


اجمالى از فعاليتها در راستاى مبارزه با فساد ادارى ومواد مخدر

قـانو

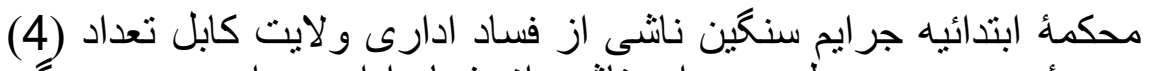

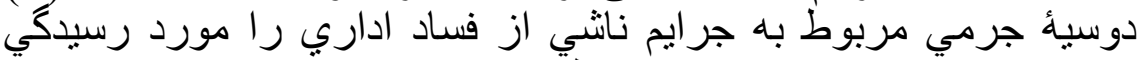

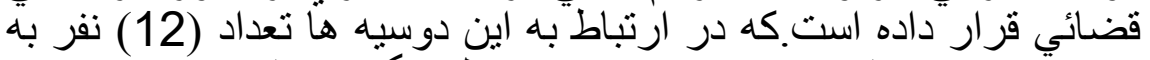

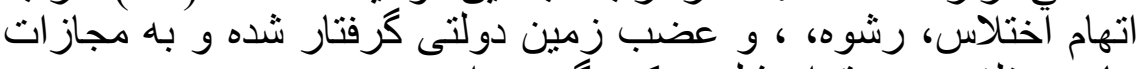

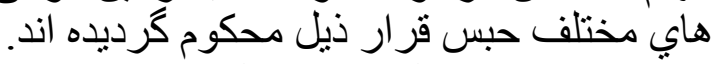

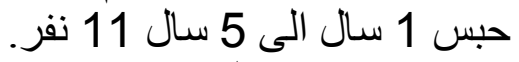
حبس 5 - 15 سال 1 نفرال مجموعه مجازات نقدى محكومين بالغ به (611434) دالر آمريكائى

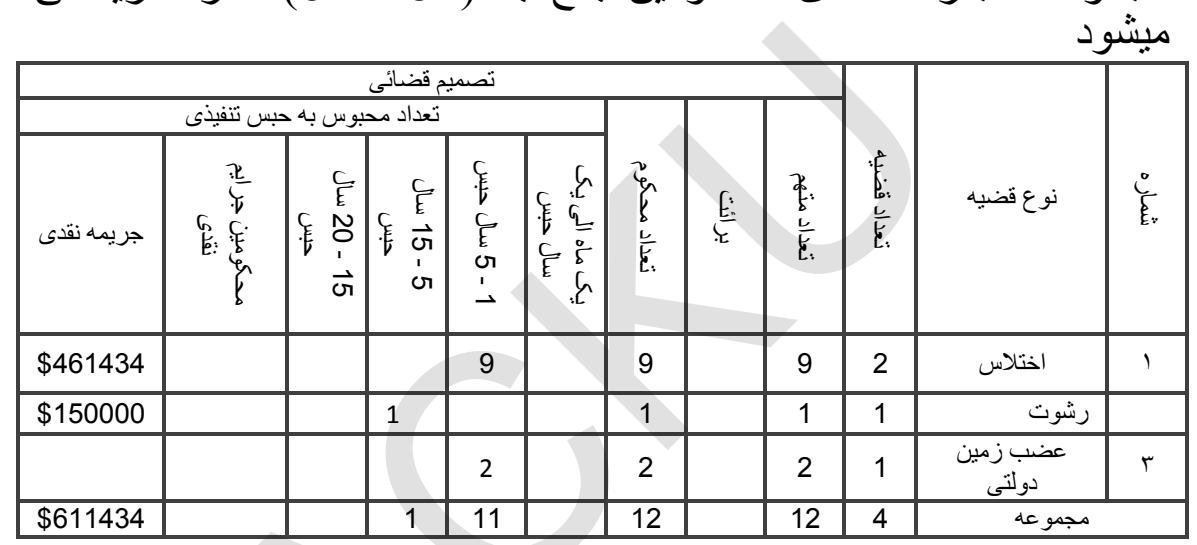

2: خلاصه نمونه هاى از احكام صادره محكمة ابتدائيه جر ايم سنكين

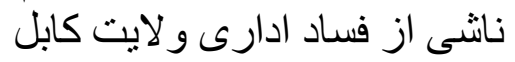

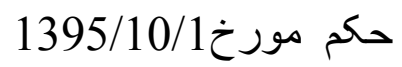

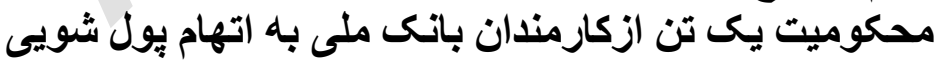

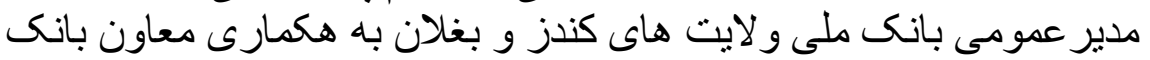

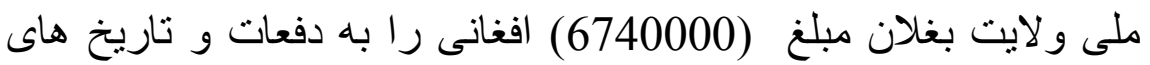

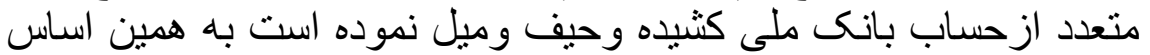

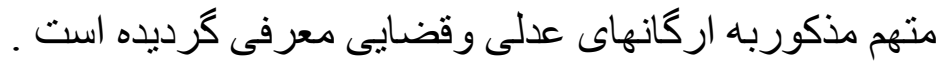

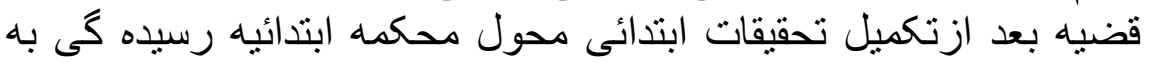

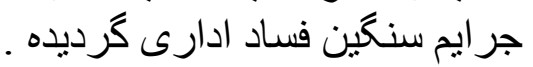


اجمالى از فعاليتها در راستاى مبارزه با فساد ادارى ومواد مخدر

قضاء

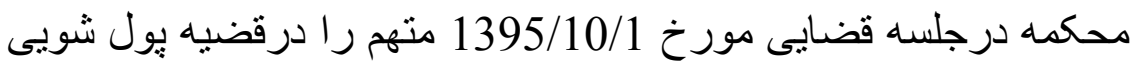

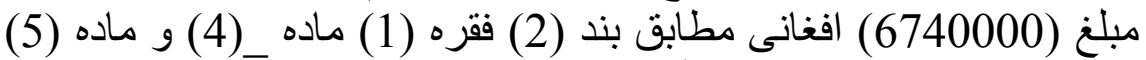

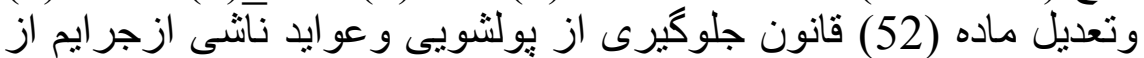

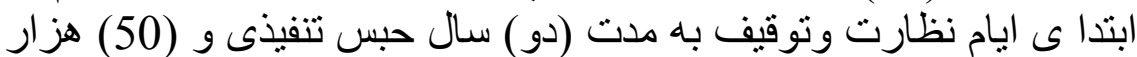

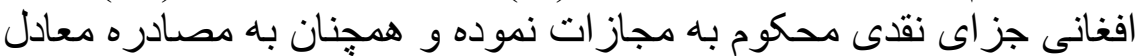

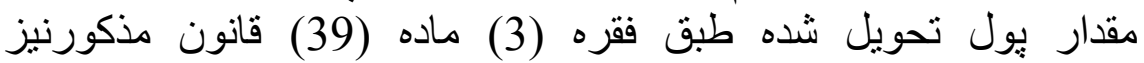

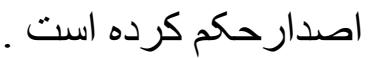

در راستاى مبارزه عليه مسكرات و مواد

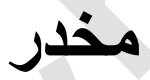

الف: كزارش اجرآت قضائى محكمة ابتدائيةٌ مبارزه عليه مسكرات و و

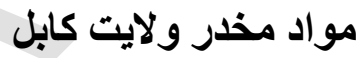

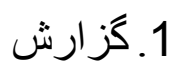

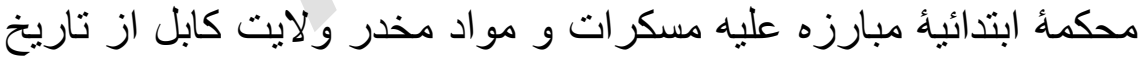

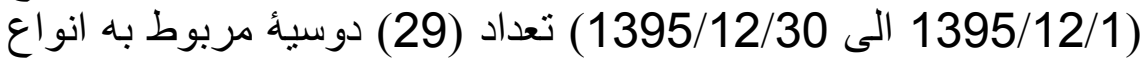

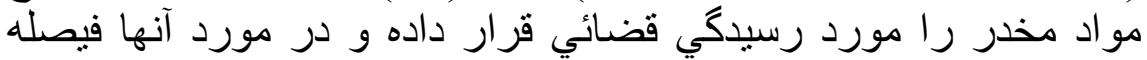

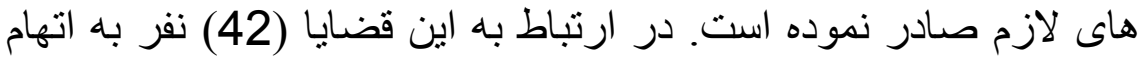

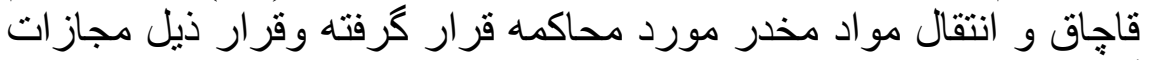
كرديده اند: 
اجمالى از فعاليتها در راستاى مبارزه با فساد ادارى ومواد مخدر

قُشاءو

$$
\text { حبس حبس } 5 \text { سال الى } 5 \text { سال } 15 \text { سال } 11 \text { نفر الى } 19 \text { نفر } 19 \text { سال } 12 \text { نفر. }
$$

در ارتباط به محاكمات فوق الذكر حكم به محو مقدار (3632/918)

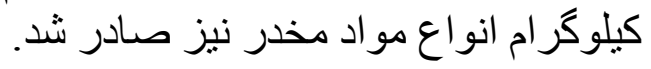

\begin{tabular}{|c|c|c|c|c|c|c|c|c|c|}
\hline \multicolumn{6}{|c|}{ تصميم قضائى } & \multirow[b]{3}{*}{ مقدار مو اد } & \multirow[b]{3}{*}{ تضداد } & \multirow[b]{3}{*}{ نوع قضيه } & \multirow[b]{3}{*}{ شماره } \\
\hline \multicolumn{4}{|c|}{ تعداد محبوس به حبس تنفيذى } & & & & & & \\
\hline $\begin{array}{c}-15 \\
20 \\
\text { حسل } 20\end{array}$ & 5 - 15 سال & 1 سال 5 حبس & ساه ليكى & محكوم تعداد & تعنهم & & & & \\
\hline 3 & & & & 3 & 3 & 146 & 3 & ترياك & 1 \\
\hline 2 & 9 & 6 & & 17 & 17 & $290 / 158$ & 14 & هيروئين & 2 \\
\hline \multirow[t]{3}{*}{7} & 4 & $\bar{x}$ & & 11 & 11 & $167 / 76$ & 6 & مورفين & 3 \\
\hline & 3 & 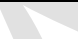 & & 3 & 3 & 490 & 2 & جֶرس & 4 \\
\hline & 3 & 5 & & 8 & 8 & 2539 ليتر & 4 & مشروبات & 5 \\
\hline 12 & 19 & 11 & & 42 & 42 & $3632 / 918$ & 29 & \multicolumn{2}{|c|}{ مجمو عه } \\
\hline
\end{tabular}

جدول شماره (1): آمار اجرآت قضايیى محكمه ابتدائيه مبارزه با

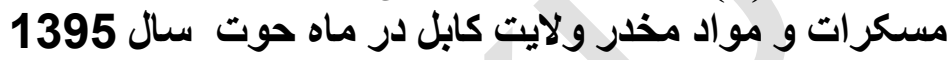

مخدر و لايت كابل.

هكم مورخ 1395/12/28

شانزده سال حبس به اتهام قاجاق مقدار(30/1/28) كيلو كرام ترياك

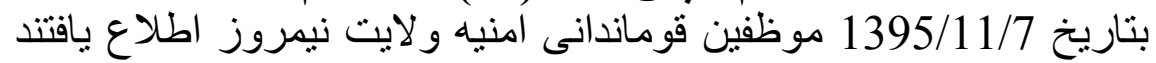

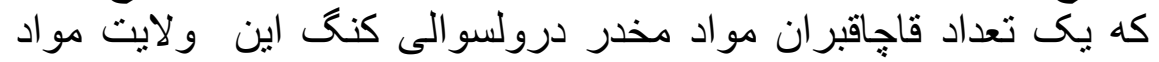

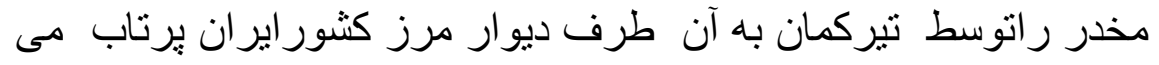


اجمالى از فعاليتها در راستاى مبارزه با فساد ادارى ومواد مخدر

قُخاءو

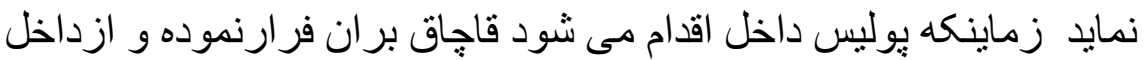

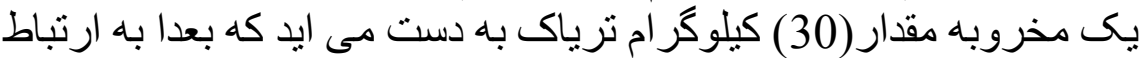

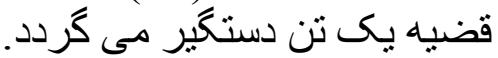
قضيه بعد ازتكميل تحقيقات ابتدايى محول دودئ محكمه مبارزه عليه مسكر ات و و

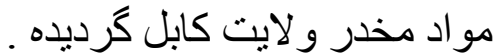

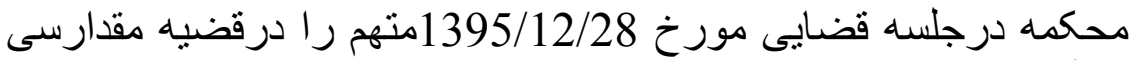

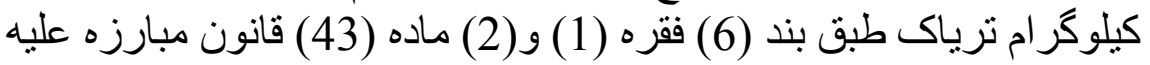

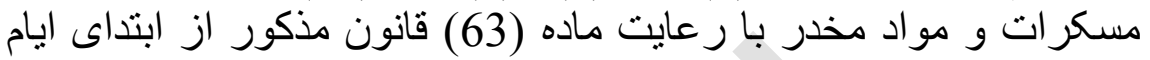

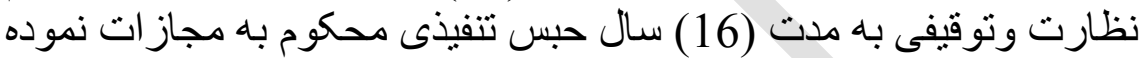

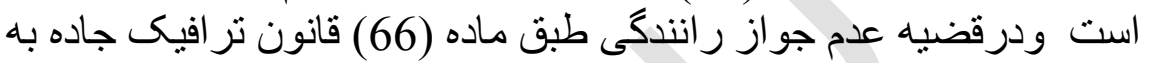

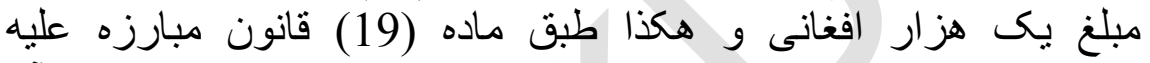

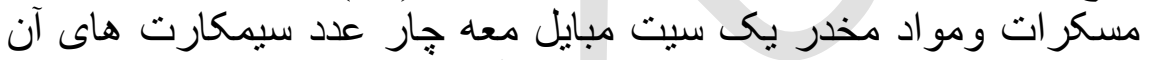

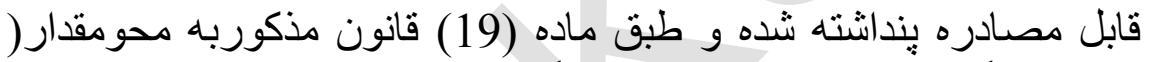

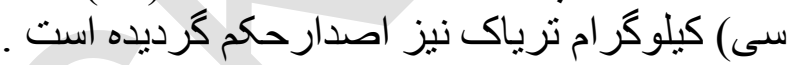

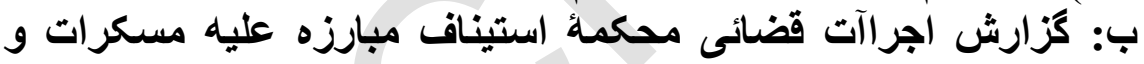
مواد مخدر ولايت كابل

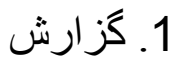

محكمة استيناف مبارزه عليه مسكر ات و مو اد مخدر و لايت كابل از تاريخ

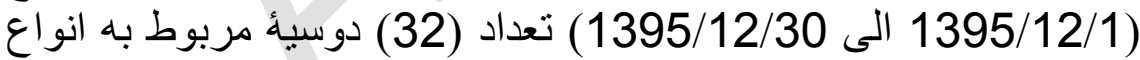

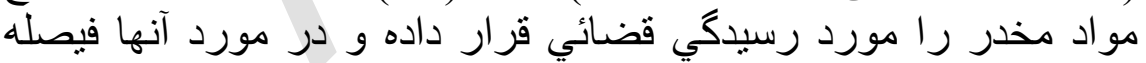

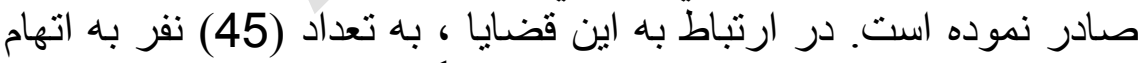

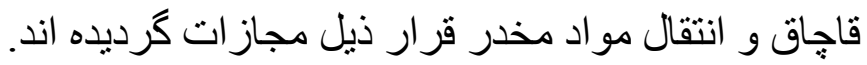

$$
\text { و حبس } 5 \text { - } 15 \text { سال } 15 \text { - } 24 \text { نفر نـ } 21 \text { نفر. } 21 \text { نفر }
$$

همجنان به ارتباط قضاياى فوق الذكر مقدار (3671/36) كيلوكر ام مواد مخدر كثف و ضبط كر ديده است. 
اجمالى از فعاليتها در راستاى مبارزه با فساد ادارى ومواد مخدر

قُشاءء

جدول شماره (1) بيانكر اجرآت قضايیى محكمه استيناف مبارزه با مسكرات و مواد مخدر ولايت كابل طى ماه حوت سال

\begin{tabular}{|c|c|c|c|c|c|c|c|c|}
\hline \multicolumn{5}{|c|}{ تصميم قضائى } & \multirow[b]{3}{*}{ مقدار مو اد } & \multirow[b]{3}{*}{ قضيد } & \multirow[b]{3}{*}{ نوع قضيه } & \multirow[b]{3}{*}{ شماره } \\
\hline \multicolumn{3}{|c|}{ تعداد محبوس به حبس تتفبذى } & \multirow[b]{2}{*}{ تعدكوم } & \multirow[b]{2}{*}{ تعدهاد } & & & & \\
\hline 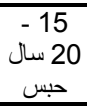 & سال 15 - 15 & سال 1 - 5 حبس & & & & & & \\
\hline 10 & & & 10 & 10 & $261 / 4$ & 7 & هيروئين & 1 \\
\hline 7 & 12 & & 19 & 19 & $852 / 09$ & 13 & ترياك & 2 \\
\hline 4 & 4 & & 8 & 8 & $155 / 87$ & 6 & مورفين & 3 \\
\hline & 4 & & 4 & 4 & 598 & 2 & جرس & 4 \\
\hline & 3 & & 3 & 3 & 1524ليتر & 3 & مشروبات & 5 \\
\hline & 1 & & 1 & 1 & 280ليتر & 1 & مو اد كيمياوى & 6 \\
\hline 21 & 24 & & 45 & 45 & $3671 / 36$ & 32 & لموعه & \\
\hline
\end{tabular}

2.خلاصه ازحكم صادره محكمة استيناف مبارزه عليه مسكرات ومو ادمخدرو لايت كابل.

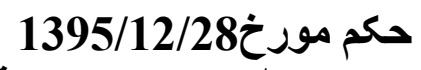
بيست سال حبس به اتهام قاجاق مقدار(24) كيلوكرام هيروئين

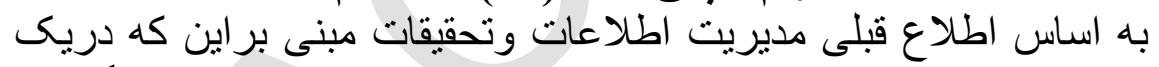

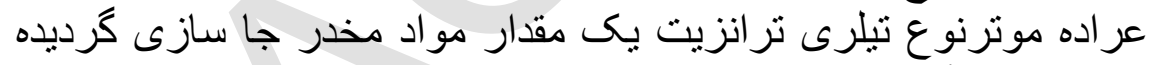

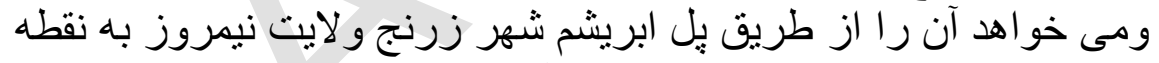

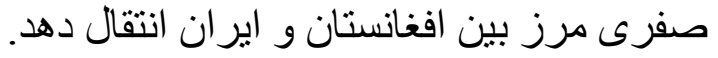

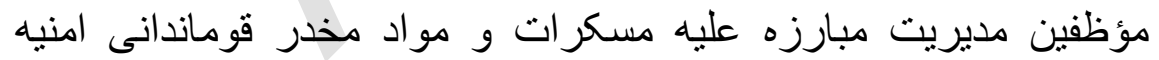

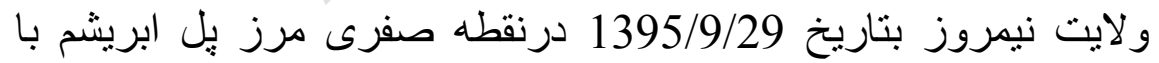

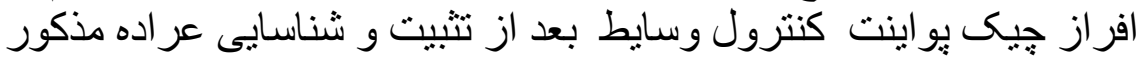

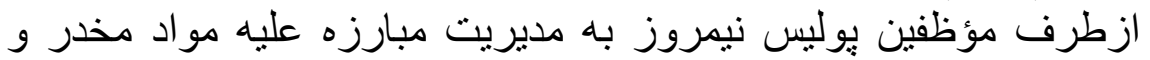

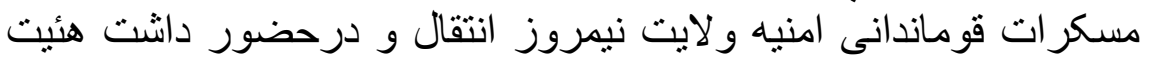

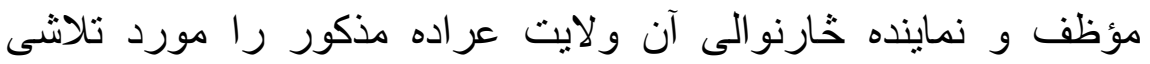


اجمالى از فعاليتها در راستاى مبارزه با فساد ادارى ومواد مخدر

\section{قُشاء}

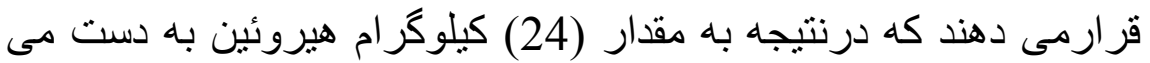

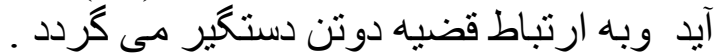

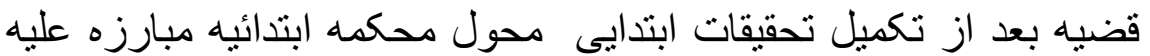

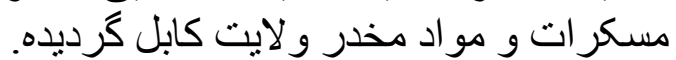

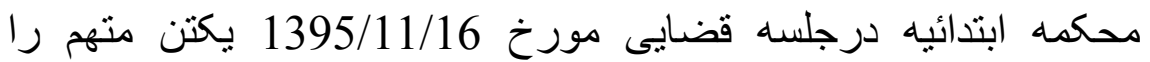

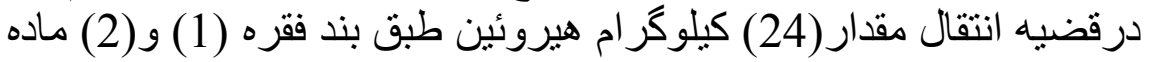

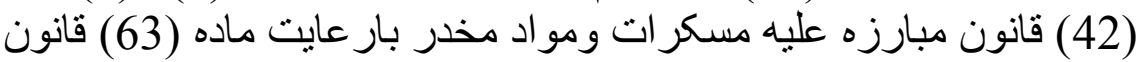

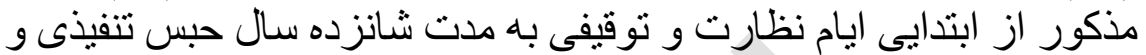

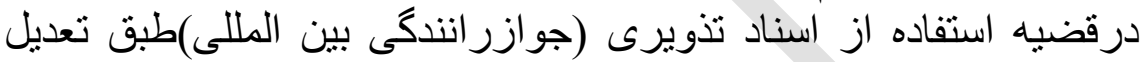

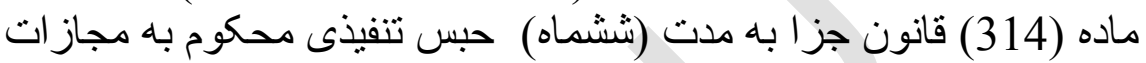

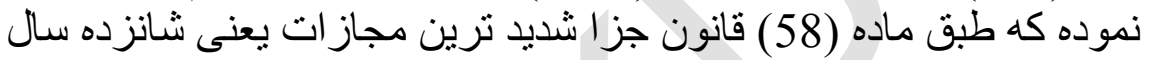

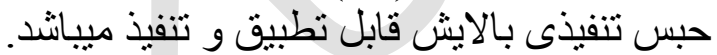

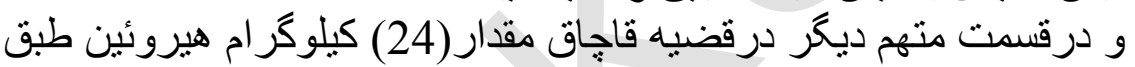

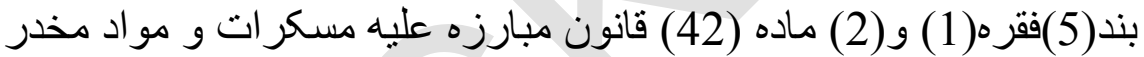

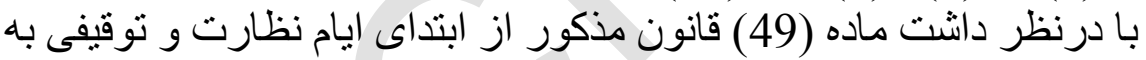

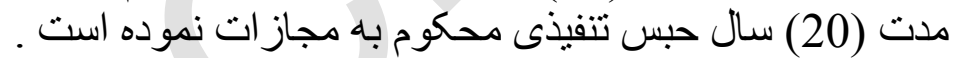

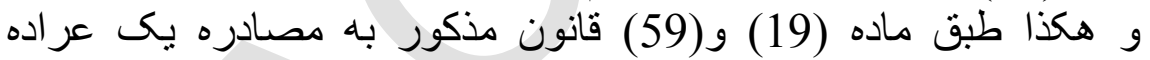

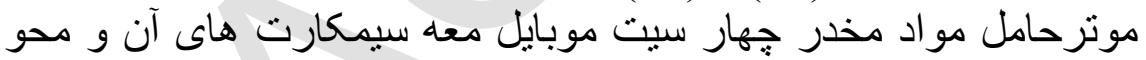

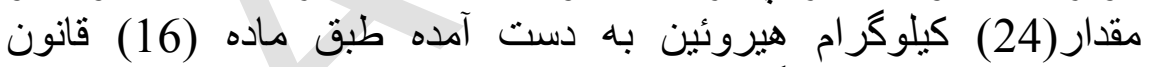

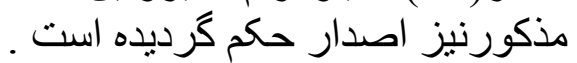

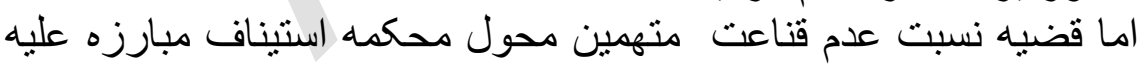

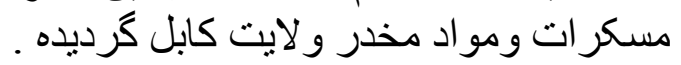

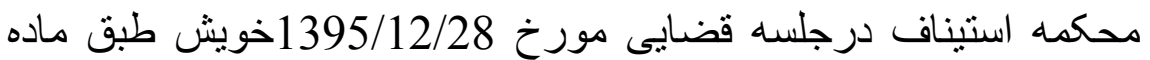

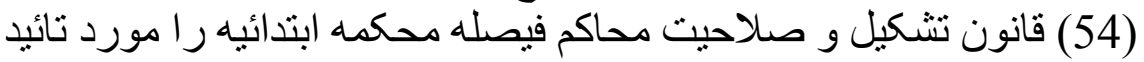

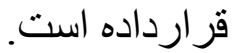


اجمالى از فعاليتها در راستاى مبارزه با فساد ادارى ومواد مخدر

\section{با نقاش در بهار}

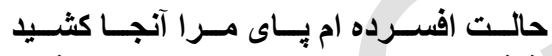

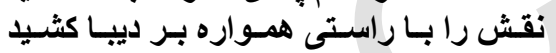

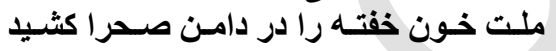

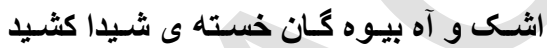

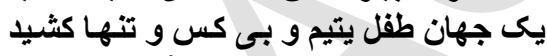

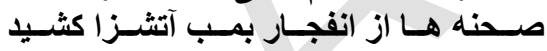

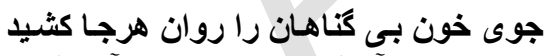

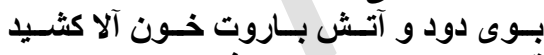

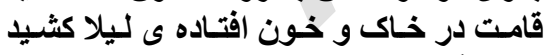

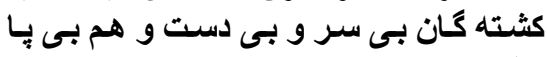

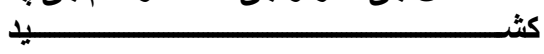
قلب دشـمن را بجـاى صـره ى صـمَّا كشيد

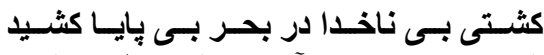

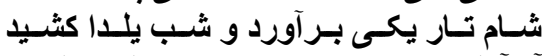

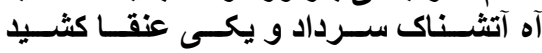

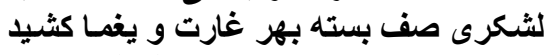

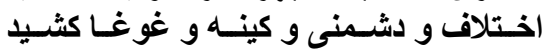

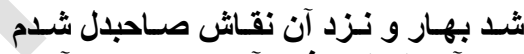

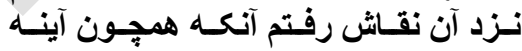

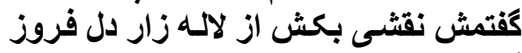

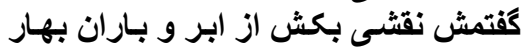

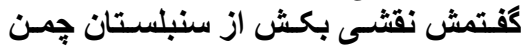
كفتمش نقشس بكش از سبزه در در دشت و

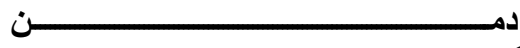
كفتمش نقشس بكش از جشـمه هـا و رود كفتمش نقشـى بكش از آن نسيم نوبهـار

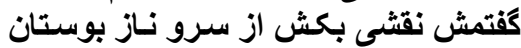

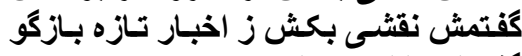

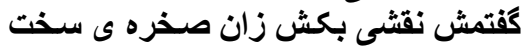

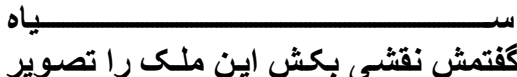

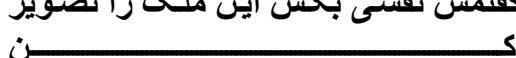
كفتمش نقشى بكش احوال ما را كن عيان 
اجمالى از فعاليتها در راستاى مبارزه با فساد ادارى ومواد مخدر

\section{قذياءو}

ديـو و غول و ازٔدر و اهريمن رسـوا كثـيد

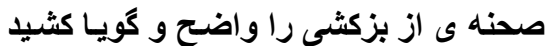

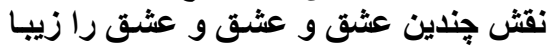

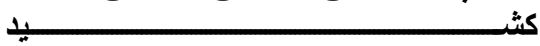
مساه و خورشيد و شـكوه كنبـد خضسرا كشيد

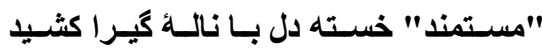

كفتمش نقشس بكس از صسورت صـلح و Li

كفتمش نقشتس بكسش از ظالمـان زورمنــ

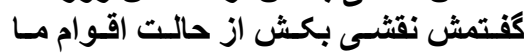

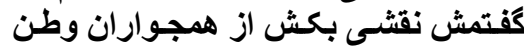

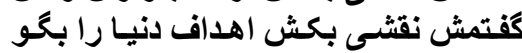

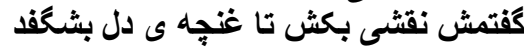

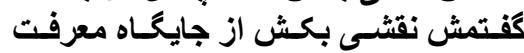
كفتمش نقشى بكش بنشكر كه تا من كيستم 